UNIVERSIDADE DE BRASÍLIA

INSTITUTO DE ARTES

MESTRADO PROFISSIONAL EM ARTES - PROFARTES

LUCAS DE CAMPOS RAMOS

\title{
O Violão de 6 Cordas e as habilidades de acompanhamento no Choro
}

BRASÍLIA 


\section{O VIOLÃO DE 6 CORDAS E AS HABILIDADES DE ACOMPANHAMENTO NO CHORO}

Dissertação de Mestrado apresentada ao Programa de Pós-graduação, Mestrado profissional em Artes - PROFARTES, Universidade de Brasília, como requisito para o título de Mestre em Artes, área de concentração Ensino de Artes

Orientadora: Profa.. Dra.. Maria Cristina de Carvalho Cascelli de Azevedo

BRASÍLIA 
Ficha catalográfica elaborada automaticamente, com os dados fornecidos pelo(a) autor(a)

DE CAMPOS RAMOS, LUCAS

O VIOLÃO DE 6 CORDAS E AS HABILIDADES DE ACOMPANHAMENTO NO CHORO / LUCAS DE CAMPOS RAMOS; orientador Maria Cristina de Carvalho Cascelli de Azevedo. -- Brasília, 2016. $175 \mathrm{p}$.

Dissertação (Mestrado - Mestrado em Música) -Universidade de Brasília, 2016.

1. Choro. 2. Violão de 6 cordas. 3. Habilidades musicais. 4. Performance em Música Brasileira. I. de Carvalho Cascelli de Azevedo, Maria Cristina, orient. II. Título. 


\section{O VIOLÃO DE 6 CORDAS E AS HABILIDADES DE ACOMPANHAMENTO NO CHORO}

Esta monografia de Mestrado Profissional em Artes foi julgada adequada para obtenção do Título de "Mestre em Artes - Ensino de Artes”, e aprovada em sua forma final.

Brasília, 09 de agosto de 2016

\section{Banca Examinadora:}

Prof. a Dra. Maria Cristina de Carvalho Cascelli de Azevedo

Universidade de Brasília - Presidente da Banca

Prof. Dr. Pedro de Moura Aragão

Universidade Federal do rio de Janeiro - UNIRIO

Membro Externo

Prof. Dr. Clodomir Ferreira

Universidade de Brasília

Membro Externo

\footnotetext{
Prof. ${ }^{a}$ Dra. Maria Isabel Montandon

Universidade de Brasília

Membro Interno - suplente
} 


\section{AGRADECIMENTOS}

Ao meu pai Oxalá e às forças da Natureza pela possibilidade e pelo privilégio de continuar aprendendo! Axé!

A toda minha família, sobretudo a minha mãe Cristina e ao meu pai Déo que me ofereceram, em casa, a melhor formação musical que eu poderia ter: a boa audição e o incentivo à curiosidade! Aos meus irmãos Tadeu e Matheus, pelos sons passados, presentes e futuros! Tonho, Regina e Mônica pelos encontros da vida. Ao meu avô Geraldo, violonista que ainda hei de conhecer! À benção vó Mariazinha, vó Dijú e vô Benedito!

À minha companheira Ana, ser humano da mais alta qualidade sem o qual eu não teria tido forças para grande parte das conquistas dessa vida. Obrigado pelas divisões e multiplicações! Aos filhotes-professores Noel e João, que me fazem ver a vida com olhos mais musicais. Amor infinito!

Aos meus professores de Violão Everaldo Pinheiro e Alencar 7 Cordas (in memorian). Muito obrigado mestres! Eternamente grato! Eternamente em dívida!

À professora Maria Cristina Carvalho, por sua inteligência elegante e por sua dedicação, mesmo diante de tantas dificuldades. Obrigado por dividir um pouco do seu impressionante universo de conhecimentos!

À professora Isabel Montandon, ao professor Clodomir Ferreira (Clodo) e ao professor Pedro Aragão pelas revisões dedicadas e correções pertinentes durante a caminhada! Muito obrigado mesmo! Ao professor José Alexandre Leme pela gentileza da leitura de parte do texto.

Aos grandes músicos que, de forma muito generosa, se tornaram parceiros dessa pesquisa: André Bellieny, Augusto Contreiras, Cláudio Jorge, Cidinho 7 Cordas, Fernando César, Jorge Cardoso, José Américo, Mário Sève, Rafael dos Anjos, Valério de Souza e Zé Paulo Becker, dentre outros. Aprendi muito e pretendo continuar aprendendo com vocês!

Aos grandes violonistas que formataram o violão de 6 cordas no Choro: Carlinhos Leite, César Faria, Dámasio e Meira, dentre muitos outros. Aos regionais que ainda hoje conservam a tradição do Violão de 6 cordas!

A todos os professores do programa de pós-graduação da UnB. Aos colegas de mestrado, obrigado pelas trocas e pela convivência nesses semestres.

Aos meus alunos da Escola de Música de Brasília, que me ensinam o tempo todo.

Aos funcionários do departamento de Música da Universidade de Brasília. Sem vocês nada aconteceria!

Ao Choro e a todos os músicos que carregam sua bandeira! 


\section{VIOLÃO}

Um dia eu vi numa estrada um arvoredo caído

não era um tronco qualquer.

Era madeira de pinho e um artesão esculpia o corpo de uma mulher.

Depois eu vi, pela noite, o artesão nos caminhos colhendo raios de lua.

Fazia cordas de prata que, se esticadas, vibravam o corpo da mulher nua.

E o artesão, finalmente, nessa mulher de madeira botou o seu coração.

E lhe apertou contra o peito, deu-lhe nome bonito e assim nasceu o violão.

(Sueli Costa) 


\section{RESUMO}

O Choro foi, e continua sendo, um estilo receptor de inúmeras influências musicais. A performance do Violão de 6 cordas (V6) no Choro, como instrumento de acompanhamento, segue essa "vocação para hibridismos" e apresenta características e especificidades que a diferenciam da performance do instrumento em outros gêneros musicais. Esta prática estimulou o desenvolvimento desta pesquisa que objetivou investigar as principais habilidades musicais do V6 enquanto instrumento acompanhador no Choro. Para realizar tal investigação, foi importante identificar quais são as principais habilidades relacionadas a essa performance e descrever essas habilidades, que estão diretamente relacionadas ao diálogo entre o V6 e o Violão de 7 Cordas (V7). O material utilizado como referência para as transcrições e análises está majoritariamente situado entre gravações do grupo Época de Ouro e os dias atuais. A dissertação se fundamenta em quatro principais fontes de dados: pesquisa documental relacionada com o contexto histórico do Choro e do Violão no Choro (BECKER, 1996; LIVINGSTON-ISENHOUR \& GARCIA, 2005; ARAGÃO, 2012/2014), pesquisa relacionada aos conceitos de competência e de habilidades musicais (PERRENOUD, 2000; SANTOS, 2007), pesquisa em material diretamente relacionado às transcrições de Violão no Choro com a análise de partituras musicais de referência (BECKER,1996/2013; BRAGA, 2002; PELLEGRINI, 2005; BITTAR, 2011) e entrevistas realizadas com importantes violonistas de 6 cordas. A metodologia utilizada propiciou identificar nas peças musicais transcritas as habilidades do V6 que foram apontadas nas entrevistas. Os resultados evidenciam a recorrência de determinadas práticas e este trabalho sistematiza algumas delas como as habilidades relacionadas com a Harmonia, as Levadas, as Inversões e as Baixarias. Elas são intimamente integradas e complementares, mas apresentam particularidades que exigem atenção, intuição e interação com os outros instrumentos, evocando um importante senso de música coletiva. O presente trabalho, naturalmente, não esgota o mapeamento das habilidades musicais do V6, mas pode auxiliar pesquisas e trabalhos, teóricos e práticos, no futuro.

Palavras-chave: Violão 6 Cordas, Choro, Acompanhamento, Performance em Música Popular Brasileira, Habilidades Musicais. 


\begin{abstract}
Choro was, and still is, a recipient style of many different musical influences. The sixstring guitar performance (V6) in Choro as an accompanying instrument follows this "hybridism skill" and bears features and peculiarities that differentiate it from this instrument's performance in other musical genres. This practice encouraged the development of this research which aimed at investigating the main musical skills of the V6 as an accompanying instrument in Choro. It was important to identify the main skills related to the dialog between the V6 and the seven-string guitar (V7), in order to accomplish this investigation. The reference materials used for the transcriptions and analysis are mainly those of Época de Ouro group recordings and those of the current days. This Master's Thesis is based on four main data sources: documental research related to the historical context of Choro and of Guitar in Choro (BECKER, 1996; LIVINGSTON-ISENHOUR \& GARCIA, 2005; ARAGÃO, 2012/2014), a research related to the concepts of competence and musical skills (PERRENOUD, 2000; SANTOS, 2007), a direct research on transcriptions of Guitar in Choro with the analysis of reference sheet music (BECKER,1996/2013; BRAGA, 2002; PELLEGRINI, 2005; BITTAR, 2011) as well as interviews of important six-string guitar players. The methodology used in this work enabled the identification of the V6 skills in musical transcriptions, as indicated in the interviews. The results show the recurrence of certain practices and this work systematizes some of them as skills that are related to the harmony, rhythm, inversions, and bass lines. They are closely linked and complementary, but present specificities that require attention, intuition and interaction with other instruments, features that evoke an important sense of collective music. This work doesn't identify the skills of the V6 in their entirety, but it can help research and other works, theorical or practical, in the future.
\end{abstract}

Key words: Six-string guitar, Choro, Accompanying, Brazilian Popular Music Performance, Musical Skills. 


\section{LISTA DE FIGURAS}

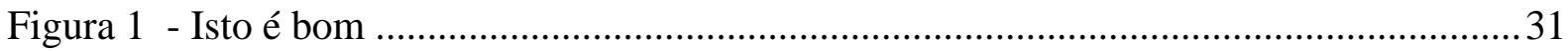

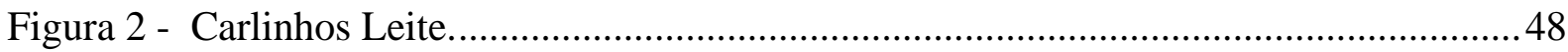

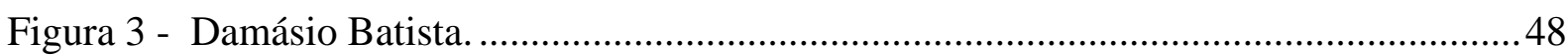

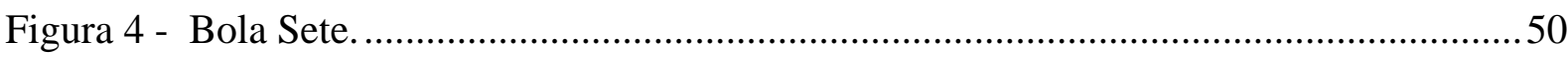

Figura 5 - Equalização do disco Vibrações. ……................................................................... 62

Figura 6 - Acordes sem tensão - trecho de Seu Lourenço no Vinho (Pixinguinha) ..............68

Figura 7 - Acordes maiores - digitações recorrentes no Choro.................................................70

Figura 8 - Acordes menores - digitações recorrentes no Choro ............................................. 70

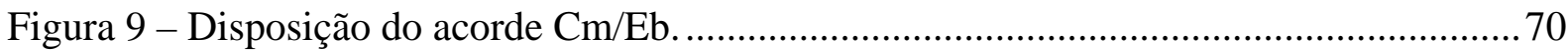

Figura 10 - Acordes dominantes - digitações recorrentes no Choro ......................................71

Figura 11 - Clichês harmônicos em tonalidades maiores ..................................................... 75

Figura 12 - cliché harmônico em tonalidades maiores.......................................................... 76

Figura 13 - variação do cliché harmônico em tonalidades maiores. .........................................76

Figura 14 - Clichês harmônicos em tonalidades menores....................................................76

Figura 15 - Clichê harmônico em tonalidade menor - exemplo. ............................................. 77

Figura 16 - Clichê harmônico em tonalidade menor no Choro ...............................................77

Figura 17 - Clichês “compartilhados”entre C e Am............................................................... 78

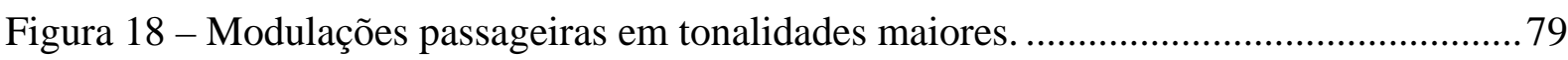

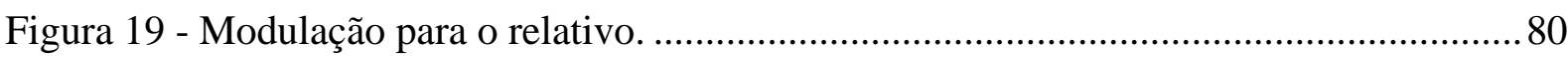

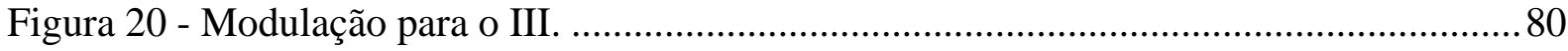

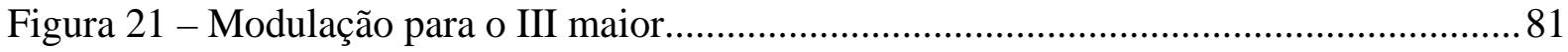

Figura 22 - Modulação para o V em tonalidade maior. .............................................................. 81

Figura 23 - Modulações passageiras em tonalidades menores. .............................................82

Figura 24 - Modulação passageira para o relativo em tonalidade menor................................. 83

Figura 25 - Modulação passageira para o Vm em tonalidade menor. ......................................84

Figura 26 - Modulação passageira para o V em tonalidade menor. ......................................... 85

Figura 27 - Modulação para tonalidade relativa - exemplo 1 (tom maior para relativo menor).

Figura 28 - Modulação para tonalidade relativa - exemplo 2 (tom menor para relativo maior). 
Figura 29 - Modulação para tonalidade homônima - exemplo 1 (tom menor para tom maior). 87

Figura 30 - Modulação para tonalidade homônima - tom maior para tom menor. ..................88

Figura 31 - Modulação para o IV - exemplo 1: tom maior....................................................... 88

Figura 32 - Modulação para o V - exemplo 1 (tonalidade maior). ........................................... 88

Figura 33 - Modulação para o Vm - exemplo 2 (tonalidade menor). .......................................89

Figura 34 - Ambiente do Brasil colônia, a dança do lundu....................................................92

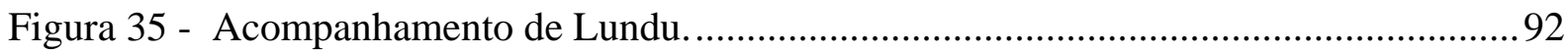

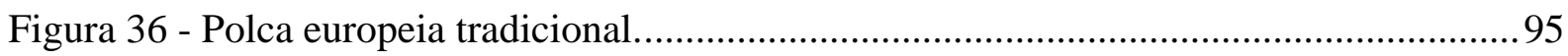

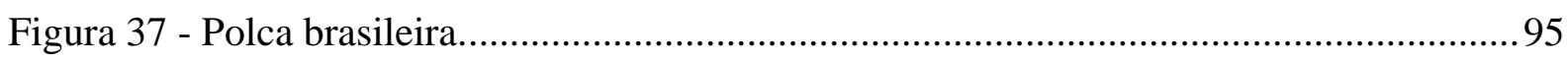

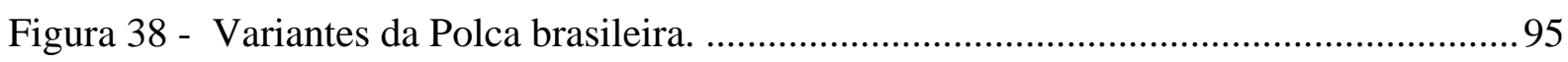

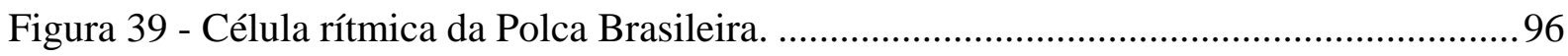

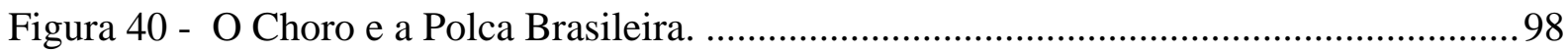

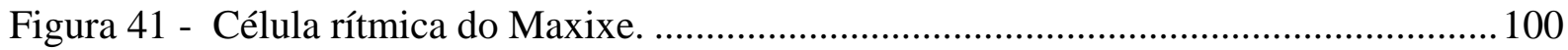

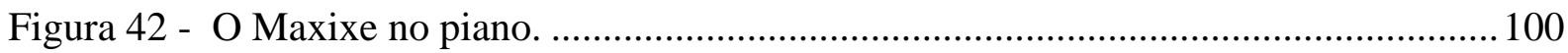

Figura 43 - Célula rítmica do Maxixe presente no acompanhamento do Tango Brasileiro...101

Figura 44 - Célula rítmica do Maxixe presente no acompanhamento do Tango exemplo2. 101

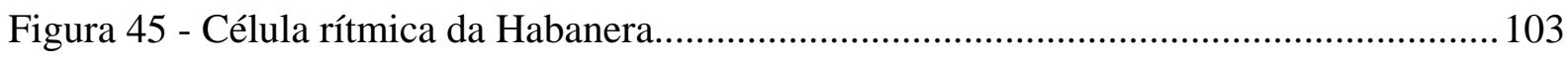

Figura 46 - Célula rítmica da Habanera presente no acompanhamento Tango - exemplo1..103

Figura 47 - Célula rítmica da Habanera presente no acompanhamento Tango - exemplo2.. 104

Figura 48 - Acompanhamento Híbrido - Gaúcho de Chiquinha Gonzaga ............................ 106

Figura 49 - Célula rítmica da Polca Brasileira. ................................................................. 107

Figura 50 - Acompanhamento de Polca. .......................................................................... 107

Figura 51 - Célula rítmica do Maxixe. ............................................................................. 107

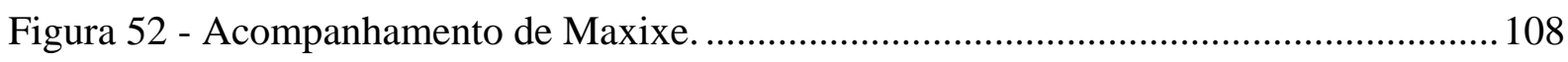

Figura 53 - Choro-Maxixe (Tango Brasileiro) .................................................................. 108

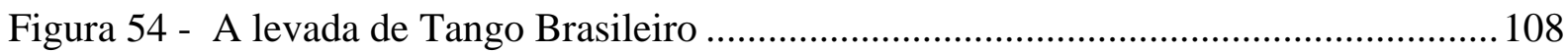

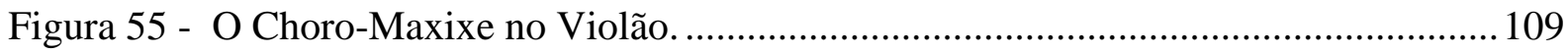

Figura 56 - Célula rítmica do Maxixe e variações. ............................................................... 109

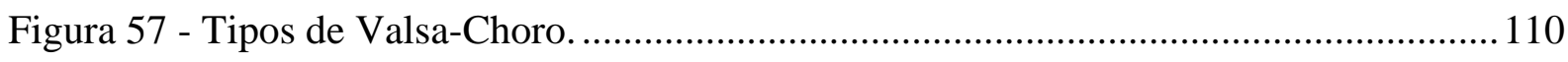

Figura 58 - O acompanhamento de Valsa tipo 1- exemplo 1.............................................111

Figura 59 - Acompanhamento de Valsa tipo 1- exemplo 2............................................... 111

Figura 60 - Acompanhamento de Valsa-Choro - tipo2...................................................... 111 
Figura 61 -Valsa-Choro.

Figura 62 - Célula rítmica do Choro- tipo 1.

Figura 63 - Acompanhamento de Choro na Bateria.

Figura 64 - Acompanhamento básico de Choro - exemplo 1.

Figura 65 - Acompanhamento básico de Choro - exemplo 2. 114

Figura 66 - Acompanhamento de Choro - variação 1. 115

Figura 67 - Acompanhamento de Choro - variação 1 - exemplo. 115

Figura 68 - Acompanhamento de Choro - variação 2.. 115

Figura 69 - Levada de Choro - variação 3. 116

Figura 70 - o Choro de Varanda 1. 116

Figura 71 - Choro de Varanda 2 116

Figura 72 - Paradigma do Estácio 117

Figura 73 - Paradigma do Estácio - variação 117

Figura 74 - Choro Sambado 118

Figura 75 - Inversões de acordes no Tango Brasileiro. 120

Figura 76 - Caminho cromático nos baixos

Figura 77 - Baixo “diatônico-cromático”. 121

Figura 78 - Caminho diatônico-cromático do baixo - exemplo 2........................................ 122

Figura 79 - Caminho cromático-diatônico do baixo - exemplo1.........................................122

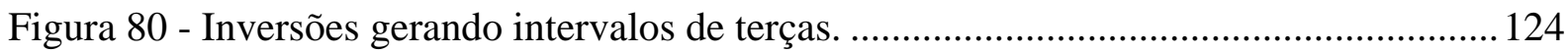

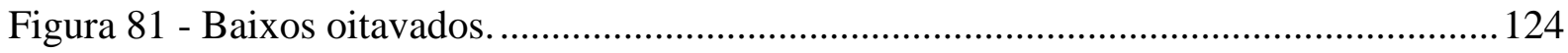

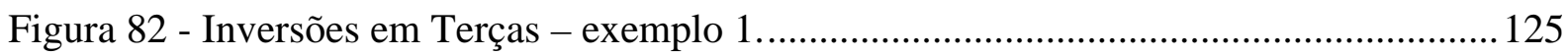

Figura 83 - Inversões em terças - exemplo 2 …............................................................... 125

Figura 84 - Inversões em terças - exemplo 3.................................................................. 126

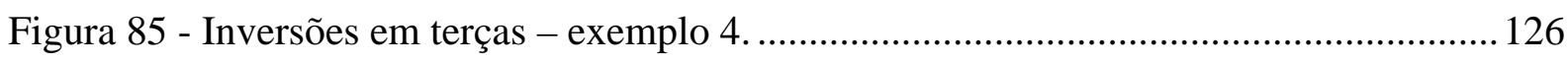

Figura 86 - Caminho cromático sobre ciclo de dominantes - exemplo 1............................. 127

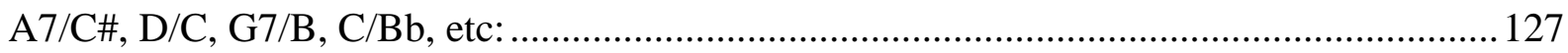

Figura 87 - Inversões no ciclo de dominantes - exemplo 1 .................................................128

Figura 88 - Caminho cromático sobre ciclo de dominantes - exemplo 2. ..............................128

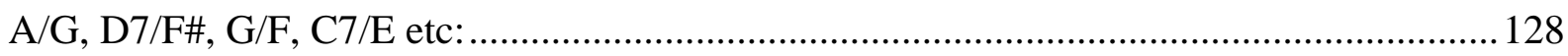

Figura 89 - Acordes invertidos e reduzidos sobre ciclo de dominantes. ................................129

Figura 90 - Inversões no ciclo de dominantes - exemplo 2...............................................129

Figura 91 - Inversão no IV em direção ao I, em tonalidade menor....................................... 130 
Figura 92 - Inversão em direção à modulação para o V menor............................................. 130

Figura 93 - Inversão sobre AEM, em tonalidade maior...................................................... 131

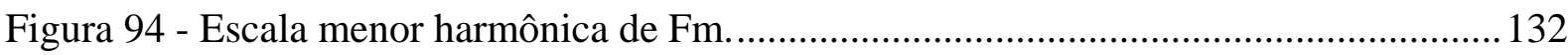

Figura 95 - correspondência funcional entre C7(b9) e Dbdim...............................................132

Figura 96 - Acorde diminuto utilizado como acorde dominante..........................................132

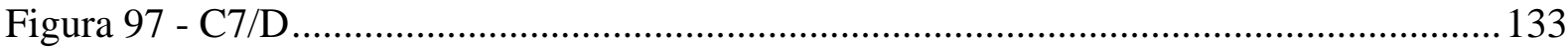

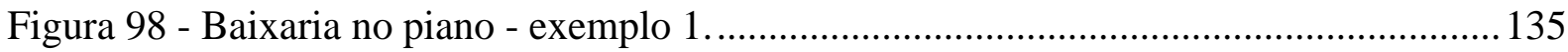

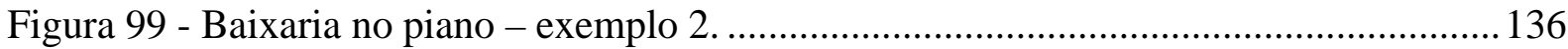

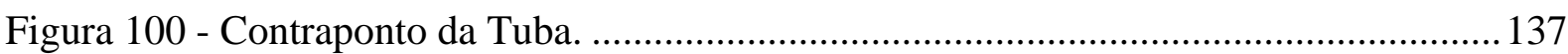

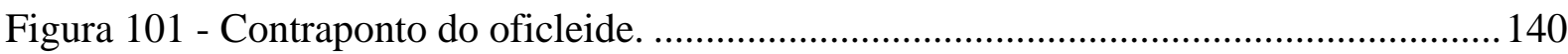

Figura 102 - Contraponto de Pixinguinha em Naquele Tempo......................................... 141

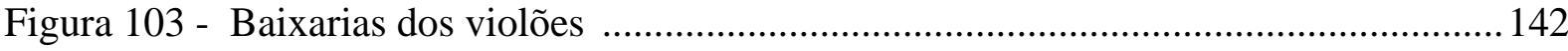

Figura 104 - A dedeira - ferramenta utilizada no Choro..................................................... 145

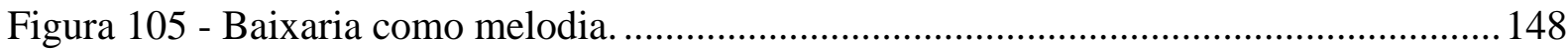

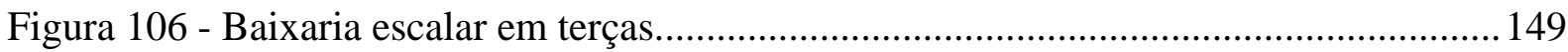

Figura 107 - Escala Dm harmônica no V7 e terças correspondentes no V6......................... 149

Figura 108 - Baixaria utilizando a escala menor harmônica - exemplo1. .............................. 150

Figura 109 - Baixaria utilizando escala menor harmônica - exemplo 2 . .............................. 150

Figura 110 - Baixaria utilizando a escala menor harmônica - exemplo 3. .............................151

Figura 111 - Baixaria em terça utilizando a escala menor primitiva - exemplo 1.................152

Figura 112 - Baixaria em terças utilizando a escala menor primitiva - exemplo 2. .............. 153

Figura 113 - Baixaria em terça utilizando a escala dórica - exemplo1..................................154

Figura 114 - Baixaria utilizando a escala dórica - exemplo 2. ….........................................154

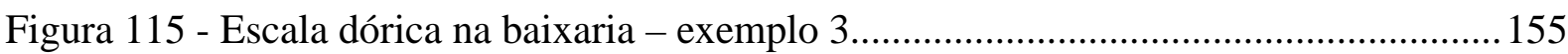

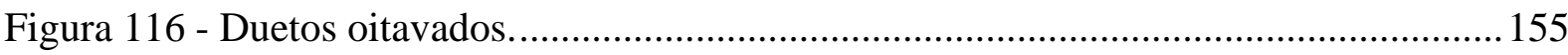

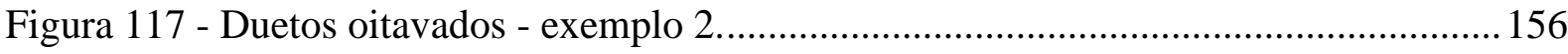

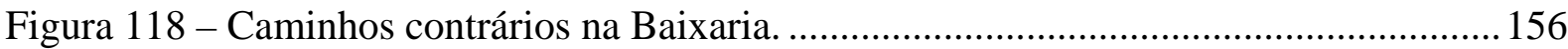

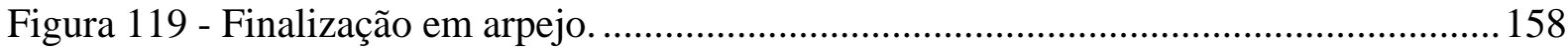

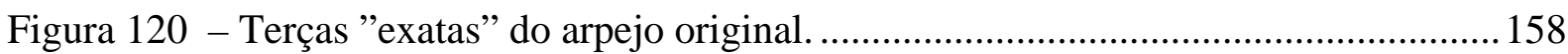

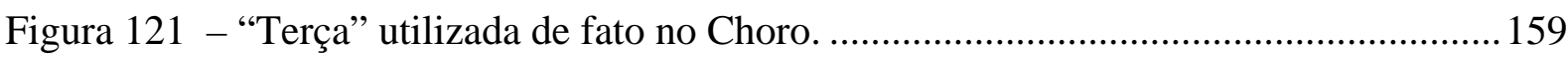

Figura 122 - Finalização em arpejo - exemplo 2. ............................................................... 159

Figura 123 - Simplificação do compasso 100 da figura 99.................................................160

Figura 124 - Acorde diminuto como inversão de acorde dominante. ...................................160 


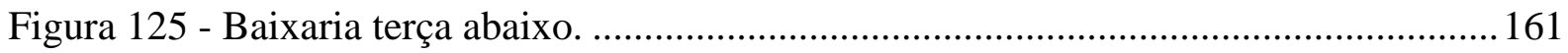

Figura 126 - Baixo de obrigação de Sofres porque queres................................................. 162

Figura 127 - Baixo realizado por Pixinguinha. ........................ Erro! Indicador não definido.

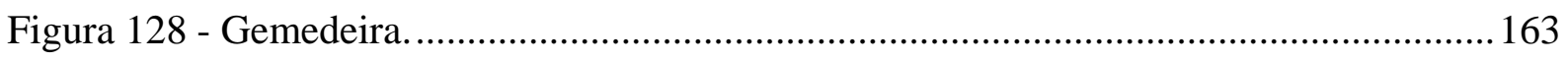




\section{LISTA DE QUADROS}

Quadro 1 - Músicos entrevistados e seu repertório básico de referência: ...............................59

Quadro 2 - Encadeamentos Harmônicos ............................................................................. 80

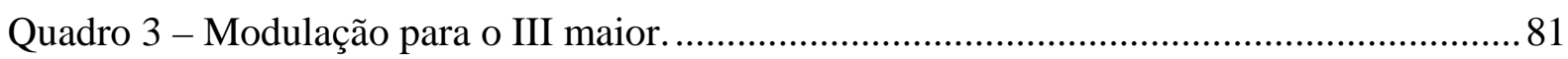

Quadro 4 - Análise de trecho com modulação para o V......................................................... 82

Quadro 5 - Análise do trecho com modulação para o relativo................................................ 84

Quadro 6 - Análise do trecho com modulação para o Vm. ..................................................... 85

Quadro 7- Acorde de F e suas inversões....................................................................... 123 


\section{SUMÁRIO}

1 INTRODUÇÃO 15

1.1 CONTEXTO $\quad 15$

1.2 OBJETIVO $\quad 16$

1.3 REVISÃO DE LITERATURA 16

1.4 JUSTIFICATIVA 19

1.5 ESTRUTURA 21

2 ASPECTOS HISTÓRICOS: as articulações culturais, o choro, o regional e o violão de 6 cordas .. 23

3 COMPETÊNCIAS, HABILIDADES E SABERES - conceitos ..................................................53

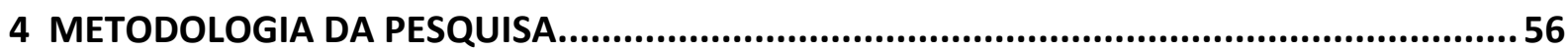

5 AS HABILIDADES DO V6 NO CHORO PARA ACOMPANHAMENTO ....................................65

5.1 HARMONIA - "Segurando a harmonia junto com o cavaquinho". 67

5.1.1. Acordes Característicos 68

5.1.2 Perspicácia Harmônica $\quad 71$

5.1.3 Modulações 78

5.2 LEVADAS - “Quando a mão direita vai bem é sinal de progresso..." 90

5.2.1 As danças europeias e as danças africanas: a origem do choro 94

5.2.2 A Levada do Choro 113

5.2.3- Choro de Varanda 116

5.2.4 Samba-Choro $\quad 117$

5.3 INVERSÕES - "O controle da harmonia sem tocar as tônicas dos acordes..." 118

5.3.1 Ciclo de Quartas Dominantes, Condução Cromática. 127

5.3.2 Inversões que resultam no Acorde Meio-Diminuto 129

5.3.3 Inversões com o V7 repousado na sétima do Acorde Dominante 131

5.4 BAIXARIAS - "Tocando em dueto com o violão de 7 cordas" 133

5.4.1 A trama - um assunto grave 146

5.4.2 O Caráter Triádico e os Arpejos $\quad 157$

5.4.3 O Caráter Triádico e os baixos repousados na sétima do Acorde Dominante 160

5.4.5 Baixarias como melodias 162

6 CONCLUSÃO - "Ninguém aprende Choro no colégio" ................................................ 165

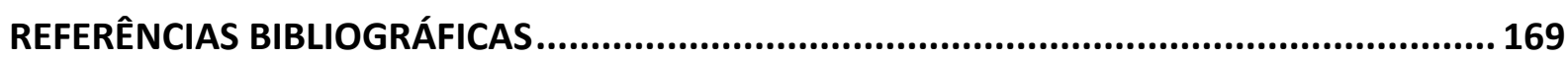





\section{INTRODUÇÃO}

\subsection{CONTEXTO}

O Choro foi, e continua sendo, um estilo receptor de inúmeras influências musicais desde o seu nascimento, marcado, sobretudo, por fusões entre músicas africanas e europeias. A performance do Violão de 6 cordas no Choro, como instrumento de acompanhamento, segue essa "vocação para hibridismos"”, e apresenta características e especificidades que a diferenciam da performance do instrumento em outros gêneros musicais.

Tais peculiaridades levaram à consolidação de uma prática instrumental bastante complexa (BECKER, 1996) que, embora represente uma importante tradição da música brasileira, ainda se encontra pouco pesquisada e registrada. Em sua construção histórica, o Choro e o Violão se nutrem um do outro, resultando numa construção recíproca, em certa medida.

Na presente pesquisa, o objeto de estudo são as habilidades musicais relacionadas à performance de acompanhamento do Violão de 6 cordas (V6) ${ }^{2}$ em um Regional de Choro.

O interesse neste tema está relacionado com as minhas duas ocupações profissionais: músico e professor de Música. Como músico, trabalho em projetos relacionados, principalmente, ao Choro e ao Samba e, como professor de Música, leciono aulas de Violão Popular e Prática de Choro no Centro de Ensino Profissionalizante Escola de Música de Brasília (CEP-EMB). Grande parte das reflexões e provocações deste trabalho vem dessas duas práticas irmãs e complementares. Como músico, venho tentando apreender as sutilezas da performance desse instrumento, e como professor venho tentando me aprimorar no ensino/aprendizagem dessas sutilezas. A Roda de Choro me ensinou que, em Música, serei eternamente aprendiz e professor. Como relata Lara Filho (2009, p.44) sobre como a Roda de Choro é um espaço dinâmico de diálogo e aprendizagem: “Na Roda, instrumentistas de diversos níveis tocam juntos, criando e recriando repertórios; nela a Música exerce, dentre outras coisas, o papel de interlocução entre as pessoas”.

\footnotetext{
${ }^{1}$ Ciente das críticas realizadas por Kartomi (1981, apud ARAGÃO 2014), o termo “hibridismo” aqui utilizado não pressupõe a existência de "raças puras” a serem misturadas, e remete apenas à miscigenação específica ocorrida no Brasil, naturalmente ocorrida por povos já anteriormente também miscigenados.

${ }^{2}$ Para facilitar a leitura passarei a utilizar a abreviação V6 ao me referir a Violão de 6 cordas. De forma análoga, o Violão de 7 cordas será tratado como V7.
} 
Durante os anos de envolvimento com este gênero musical, pude notar que o V6, instrumento típico dos Regionais de Choro, é detentor de muitas especificidades e idiomatismos. Como instrumentista desse instrumento, percebo a sua importância e me interesso pela sua dinâmica no regional, ou seja, sua performance individual e sua interação com os outros instrumentos. Segundo Kerman (1985 apud ORIONE, 2014, p.14), o musicólogo, pesquisador musical, frequentemente se interessa pela música que executa: “a música pela qual os musicólogos se interessam é aquela que faz parte de sua cultura, de sua própria tradição nacional ou, em se tratando de sacra, de sua religião”.

Portanto, o meu interesse investigativo no V6 nasce dessa experiência profissional e da familiaridade com suas especificidades no conjunto de Choro, seja como músico ou professor. O V6 é um instrumento que possui diversas funções dentro de um Regional, o que, sinteticamente, poderia se resumir em “a função de dar equilíbrio” ao grupo de Choro. Mas como esse equilíbrio é assegurado? Quais habilidades musicais o instrumentista deve desenvolver para exercer uma boa performance nesse instrumento? O que violonistas relatam sobre a prática do instrumento, sua performance, e sua importância no regional de Choro? O que pode ser absorvido através de gravações importantes? De que forma o Violão de 6 Cordas se relaciona com o Violão de 7 Cordas? Essas questões orientam esta dissertação, e mediante buscas de respostas para elas que está estruturado o trabalho.

\subsection{OBJETIVO}

A pesquisa tem como objetivo, portanto, investigar as principais habilidades musicais do V6 enquanto instrumento acompanhador no Choro, sobretudo a partir da performance no conjunto Época de Ouro. Para realizar tal investigação, foi importante descobrir quais as principais habilidades relacionadas a essa performance, identificar e descrever essas habilidades (a partir das entrevistas e de músicas de referência) e descrever a relação entre os violões. O material utilizado como referência para as transcrições e análises está majoritariamente situado entre gravações do grupo Época de Ouro e os dias atuais.

\subsection{REVISÃO DE LITERATURA}

Para realizar contextualização histórica do objeto de estudo, me vali de alguns textos importantes. 
A despeito da simplicidade a que costumam relacioná-lo, o livro O Choro, de Alexandre Gonçalves Pinto (2009), é com certeza um valioso documento a respeito do Choro e, principalmente, dos chorões mais antigos. Segundo o bandolinista e pesquisador Pedro Aragão, trata-se de "documento chave para o entendimento do choro no início do século e uma das principais fontes de pesquisa de todos os pesquisadores do gênero”. (ARAGÃO, 2012, p.879). Fonte bibliográfica primordial para aqueles que se interessam pela história do Choro, o livro de Alexandre foi utilizado para melhor conhecer sobre a história dos violonistas mais antigos. Na linha da perspectiva histórica do Choro, outros trabalhos foram muito importantes, como a publicação do cavaquinista e pesquisador Henrique Cazes, chamada Choro: do quintal ao municipal (1998), as publicações Almanaque do Choro (2003) e Callado: o pai dos chorões (2002), ambas do pesquisador André Diniz e o livro Choro: the social history of a brazilian music, de Livingston e Garcia (2005), dentre outros.

A violonista e pesquisadora Márcia Taborda ofereceu a essa pesquisa valiosas informações a respeito da implementação do Violão no Brasil e a respeito da forma como o Choro e o Violão se nutriram mutuamente em sua publicação Violão e Identidade Nacional (2011). Taborda possui ainda importante publicação a respeito da performance do músico Dino 7 Cordas.

O tema do Violão de 7 Cordas também é tratado pelo pesquisador Remo Pellegrini, em sua dissertação Análise dos acompanhamentos de Dino 7 Cordas em Samba e Choro (2005). Este trabalho consiste na transcrição e análise de uma amostra da obra do violonista Dino 7 Cordas, de onde o pesquisador extrai e cataloga elementos que sirvam de subsídio ao estudo do Violão de 7 cordas. Após completar o conjunto das análises, Pellegrini tece alguns comentários sobre comportamentos comuns ou relacionando diferenças e possíveis razões para que ocorram. O pesquisador apresenta a transcrição e análise de motivos musicais utilizados por Dino 7 Cordas em gravações de Samba e Choro. Parte do método de análise sugerido por Pellegrini foi usado em minhas análises, no entanto, naturalmente, estendi o processo ao Violão de 6 Cordas, principal objeto de estudo da presente pesquisa. A dissertação do professor José Alexandre Leme, intitulada Os alicerces da folia (2006), auxiliou no aprofundamento das questões relacionadas aos contrapontos do V7 e V6.

O violonista e pesquisador Felipe Pessoa, em sua pesquisa Cuidado Violão (2012), trata o tema dos duos de violões nos acompanhamentos, e sugere que, a partir das gravações existentes, é possível delimitar a performance dos violões de Choro em 3 períodos distintos. A partir da Metodologia do Triângulo (FERREIRA, 2012), Pessoa demonstra como a produção 
musical, o contexto social e os meios de comunicação dialogam na produção do objeto musical. Neste trabalho, Pessoa assim concebe as 3 diferentes fases: os grupos de Choro de 1907 a 1915, os Regionais da Era do Rádio, e o Conjunto Época de Ouro, na década de 60 do século XX. Para o pesquisador, cada um desses períodos apresenta paradigmas específicos na forma de acompanhamento dos violões. O trabalho de Pessoa é pioneiro ao tratar a dupla de violões como objeto de estudo. Concordo com ele quando sugere que a última fase mencionada, relacionada diretamente ao Conjunto Época de Ouro, seja a fase que mais influenciou as gerações seguintes de chorões. As explicações para o fato estão relacionadas ao rigoroso tratamento camerístico dispensado por Jacob e seus parceiros e às importantes alterações na tecnologia de gravação, que possibilitaram que as gravações pudessem ser feitas em canais separados. A maior parte das transcrições e análises realizadas na presente pesquisa são de gravações realizadas a partir desse período.

É exatamente sobre essa fase do Choro que o violonista e pesquisador José Paulo Becker se debruça em sua pesquisa intitulada Análise do acompanhamento do Violão de 6 Cordas a partir de sua visão no conjunto Época de Ouro (1996). Neste trabalho pioneiro sobre o Violão de 6 Cordas, Becker oferece importantes referências a respeito do funcionamento do V6 dentro de um regional, através de transcrições e análises detalhadas. A pesquisa de Becker é considerada inspiração para a presente pesquisa, em que é frequentemente utilizada, direta ou indiretamente. No entanto, procurei oferecer as transcrições e análises a partir da dupla de violões, e não apenas do Violão de 6 Cordas, como forma de entender o funcionamento complementar que os violões realizam.

Com temática específica sobre o V6, serviu de referência também a dissertação Fixando uma gramática: Jayme Florence (Meira) e sua atividade artística nos grupos Voz do sertão, Regional de Benedito Lacerda e regional do Canhoto, de Iuri Bittar (2011). Este trabalho trata majoritariamente da performance do violonista Meira em três trabalhos profissionais, oferecendo trechos escritos e analisados de sua performance, utilizando para tal alguns conceitos da metodologia dos museumas utilizada por Phillip Tagg. A pesquisa oferece ainda importantes aspectos históricos e biográficos do violonista Meira.

Outra pesquisa amplamente utilizada em minha dissertação é O Choro dos Chorões de Brasília (2009) do clarinetista e pesquisador Ivaldo Lara Filho. Em seu trabalho, o pesquisador faz um estudo de caso a respeito dos músicos de Brasília vinculados ao ambiente do Choro. E tece previamente uma importante contextualização acerca do Choro. Além disso, ele faz valiosas considerações sobre a complexidade e diversidade da Roda de Choro, 
apontando intimidades e semelhanças com o contexto da Roda de Samba proposto por Moura (2004).

Algumas outras publicações complementaram o estudo no que diz respeito às competências musicais no violão de Choro.

A Teoria das Árvores Harmônicas de Alencar 7 Cordas, ainda não publicada, amparou o estudo da habilidade musical Harmonia.

Já no estudo da competência Levadas (ou seja, a performance da mão que tange as cordas do violão, normalmente responsável pela condução rítmica), foram muito importantes os trabalhos: Levadas brasileiras para violão, de Becker (2013); Ritmos Brasileiros, de Marco Pereira (2007); Fixando uma gramática: Jayme Florence (Meira) e sua atividade artística nos grupos Voz do Sertão, Regional de Benedito Lacerda e Regional do Canhoto (2011), de Iuri Bittar; Apostila de Maurício Carrilho (2007), o livro Feitiço Decente: transformações do samba no Rio de Janeiro: 1917- 1933 de Sandroni (2001), a dissertação Chiquinha Gonzaga e o Maxixe de Clara Marcílio (2009), dentre outros.

Da forma semelhante, os trabalhos de Becker (1996), Bittar (2011), Braga (2002), Pellegrini (2005) e Leme (2006) foram muito importantes para iluminar o estudo das habilidades Inversões e Baixarias.

\subsection{JUSTIFICATIVA}

O violonista Maurício Carrilho, na introdução do Songbook de Choro editado por Almir Chediak, afirma que:

(...) a coisa mais importante do Choro são essas sutilezas que foram passadas de geração em geração. E que não são possíveis de serem colocadas em partitura, não dá pra escrever isso, não dá pra codificar. São coisas que você só pega convivendo, tocando junto, prestando atenção. (2007, p.42).

Naturalmente, importantes trocas de partituras já existiam entre os antigos chorões (ARAGÃO, 2012. No entanto, tradicionalmente o ensino/aprendizagem no Choro se deu, principalmente, em contextos informais. Apesar de muitos avanços importantes, infelizmente, ainda há pouca quantidade de material pedagógico sistematizado sobre o tema. A tradição oral ainda predomina no gênero, nas palavras de Lara Filho (2009, p.88) “Desde o seu surgimento, a tradição do Choro apoiou-se na tradição oral. (...) a tradição oral ainda é o alicerce de transmissão e renovação desse patrimônio cultural”. 
Especificamente, sobre o Violão de 6 Cordas, a escassez é ainda maior, como aponta o violonista e pesquisador Becker (1996, p. 93), que realizou importante e pioneira pesquisa sobre este assunto: “concluímos que o Choro fez surgir um tipo de acompanhamento de violão bastante característico que, apesar de seu importantíssimo papel na história de nossa música, está restrito ao conhecimento das pessoas ligadas ao meio”. Em entrevista para a pesquisa, o bandolinista e pesquisador Jorge Cardoso afirma que: “Ao ser acompanhado por violões no Choro, observei regras e sistemas da música improvisativa e popular, que ainda não foram codificadas em um ensino sistematizado em escolas de ensino formal de música no Brasil”. (JORGE CARDOSO, 2015, E., p.28).

Apesar do reconhecimento dessa importância, tem-se observado uma importante diminuição da participação desse instrumento nas atuais formações de Choro, como podemos notar em Pessoa (2012, p.9): “essa formação encontra-se em escassez nos grupos profissionais dispersos por todo país, tanto por questões econômicas quanto por habituais renovações, o que acrescenta um teor de temporalidade a esse modo de acompanhamento, intensificando, assim, o seu caráter de tradição”. O violonista Fernando César, em depoimento para a presente pesquisa, também, demonstra sua preocupação com o tema, sobretudo a partir do menor tempo de convívio entre os músicos nos dias atuais:

Hoje o V6 praticamente não existe mais. O motivo principal é a falta de tempo dos músicos. (...) Com a falta de tempo que os músicos têm hoje, este instrumento está em extinção. Dificilmente a gente conseguirá mudar isso, é muito difícil. O fator tempo detonou várias coisas. Detonou a maneira natural de se tocar junto, no olhar, na sensibilidade... prever o que o outro irá fazer. Hoje lamentavelmente o V6 está em extinção (CÉSAR, 2015, E, p.27).

O músico Cidinho 7 Cordas, que também é um dos chorões entrevistados da pesquisa, mencionou a atual preferência pelo V7: “(...) pois o 6 cordas, ou segundo Violão está em extinção, todos querem sair no 7”. (CIDINHO, 2015, E., p.9). Em relação à pequena procura pelo V6 nos dias atuais, o músico Valério de Souza expressou: “(...) a turma mais jovem vai acabar tocando harpa ou cítara! (...)”, em uma bem-humorada alusão à quantidade de cordas do V7 ou mesmo do violão de 8 cordas. No entanto, ele não crê no desaparecimento do instrumento: “isso (o desaparecimento) não vai acontecer. Veja que tem bons acompanhadores no Choro atual. Tem o Rafael dos Anjos, esse menino do Choro Livre que faz um 6 cordas de responsa. Você também está no rol. (...) Se todo mundo for tocar V7 vai 
ser um Choro diferente (...) “. (SOUZA, 2015, E., p.38). O violonista Rafael dos Anjos, acima citado, afirma que:

Essa escola de violão infelizmente está quase extinta no Brasil. São poucos os regionais que ainda mantém a formação com 6 cordas, tocando como se deve. Acredito que trabalhos como o dos regionais Época de Ouro, Choro Livre, Regional Imperial, Choro pra 5, Alencarinos, e alguns outros regionais que colocam o 6 cordas em sua formação, possam incentivar mais os jovens, os iniciantes amantes do choro e os adeptos do gênero novos e antigos a não deixar essa cultura morrer. (ANJOS, 2016, E., p.32).

O violonista José Américo demonstra preocupação com o futuro do V6: “A tendência é que o V6 desapareça. Está aumentando o número de violonistas de 7 cordas, o V6 pode acabar sumindo do Choro (...) A própria oferta de shows tenta diminuir a quantidade de músicos, tem pressão comercial.” (AMÉRICO, 2016, E., p.3)

Portanto, se por um lado, é possível imaginar uma transformação musical interna do estilo, por outro lado, há motivos externos que intervêm nesse contexto musical, como: questões financeiras, logística de ensaios e dificuldade em se aprender o instrumento. No entanto, este trabalho não pretende se aprofundar nessas questões e deixo essa provocação para futuras pesquisas. O fato é que, independentemente de quais sejam os fatores intervenientes, a performance do V6 no Choro é uma tradição musical brasileira que parece estar se diluindo, posta a menor frequência em que os Regionais têm usado o instrumento em suas formações. Segundo Pessoa (2012, p.9): “Considerada tradicional e presente no processo de aprendizado do chorão, essa prática do duo de violões trabalhando juntos não é tão constante como outrora, mas ainda traduz o paradigma de grupo de choro e, evoca o conceito de tradição”.

Diante deste cenário, percebo a relevância de identificar e sistematizar as principais habilidades e conhecimentos relacionados à performance do V6 no Choro como forma de qualificação da performance dos estudantes e de preservação dessa tradição musical.

\subsection{ESTRUTURA}

Na introdução procurei contextualizar a pesquisa e problematizar o objeto de estudo, bem como apresentar o objetivo, a justificativa da pesquisa, a revisão de literatura e essa estrutura do trabalho. 
No capítulo 2, procurei contextualizar historicamente o Choro, os Regionais de Choro e o Violão no Brasil. No entanto, diante dos pronunciados aspectos de miscigenação de culturas envolvidos, determinantes para a compreensão da formação cultural brasileira, iniciei o capítulo com um breve panorama da Música no Brasil a partir da chegada dos portugueses. Em seguida, apresento os aspectos históricos que possibilitaram o surgimento do Choro e a consolidação do Violão no Brasil. Apresento ainda um pouco da história dos regionais de Choro, que são arregimentações específicas, ainda hoje utilizadas nas formações típicas de Choro, e que tiveram seu auge na Era do Rádio. Por se tratar de um período histórico muito amplo, é apresentada uma rápida visão panorâmica sobre o assunto. Mesmo ciente dos riscos da superficialidade, acredito ser necessária tal contextualização, pois determinados fatos históricos terão influência direta na execução musical.

Uma rápida conceituação dos termos Saberes, Competências e Habilidades é apresentada no capítulo 3, uma vez que tais conceitos serão utilizados no capítulo 5.

No capítulo 4 é apresentada a Metodologia da pesquisa, onde estão registrados os principais aspectos utilizados nas entrevistas e nas transcrições.

No capítulo 5, enfim, são expostas as principais Habilidades Musicais relacionadas à performance do V6, amparadas nas entrevistas e respaldadas pelas análises da transcrições.

No capítulo 6 apresento a conclusão do trabalho e as perspectivas que dele possam nascer. 


\title{
2 ASPECTOS HISTÓRICOS: as articulações culturais, o Choro, o Regional e o Violão de 6 cordas
}

\begin{abstract}
As representações da história são moldadas a partir de signos culturais (incluindo aí também certamente os signos sonoros) para a produção de discursos. Este processo envolve uma verdadeira "rede" de mediadores formada por diversos atores sociais, que ao longo deste período se entrelaçam através de uma teia complexa que envolve fatos sociais, memória, história, interpretação, paixão musical, entre outros elementos. (ARAGÃO, 2012, p.88)
\end{abstract}

A epígrafe acima destaca a participação dos signos sonoros, inclusive a música, na representação da história. De forma semelhante, porém sob perspectiva inversa:

Se quisermos compreender as práticas musicais, é preciso sim observar a sociedade onde ela é feita; não podemos nunca analisá-la fora do contexto sociológico e histórico, e muito menos, esquecer de observá-la como uma forma cultural, sujeitas às mobilidades sociais, à criação do signo musical e à sua decodificação. (MONTEIRO, 2010, p.84)

A citação acima destaca o caráter sociocultural da produção musical. Portanto, no contexto sociocultural brasileiro, para uma melhor compreensão da Música a que estamos nos referindo é preciso destacar que a constituição do material cultural brasileiro se deu, principalmente, a partir do encontro das matrizes lusitana, africana e indígena (RIBEIRO, 1995). Segundo Castagna (2010, p.37):

A miscigenação racial no país fez com que, da mistura de elementos musicais praticados por vários povos, surgissem novos tipos de música, sempre em transformação até os tempos atuais, porém mantendo suas características espontâneas até hoje. É esse o tipo de música que, a partir do final do século XIX, começou a ser definido como folclórica ou popular.

Diante destas afirmações, acredito que, em uma contextualização histórica acerca da genealogia da cultura brasileira, e em muito particular da música, é prudente levar em consideração a forma como estas trocas ocorreram, ou nas palavras do historiador Maurício Monteiro (2010), a forma como se deu a “articulação” de culturas diversas. Por esse motivo, uma pequena digressão acerca dos períodos iniciais relativos a esse embate cultural será apresentada.

No entanto, o sociólogo Jessé de Souza (2015) aponta críticas ao “mito das 3 raças” da forma como foi defendido por Gilberto Freyre (1930) e Sérgio Buarque de Hollanda (1936), e incentivado por Vargas, sobretudo na utilização deste mito para a construção do perfil 
psicológico do brasileiro, marcado pela cordialidade nessa perspectiva. Procurei, mesmo considerando a relevância do encontro de culturas diferentes, me desviar dos aspectos relacionados à formatação do perfil do brasileiro e me ater aos aspectos musicais dos enfrentamentos culturais.

Um fator determinante nesse conjunto de embates culturais foi a política expansionista marítima portuguesa. A chegada dos portugueses no século XVI à América marcou, na visão dos europeus, o “descobrimento” de uma nova terra. Na visão dos povos indígenas, a chegada dos portugueses ao seu continente provavelmente significou um período de conflitos e estranhamentos, decorrentes, sobretudo, da escravização a que foram submetidos e das intensas trocas culturais. Malgrado aquilo que reproduziram por muito tempo os livros escolares, insinuando aos indígenas brasileiros uma personalidade preguiçosa e indolente, o sucesso comercial da plantation no Brasil está diretamente ligado à utilização da mão-de-obra indígena em conjunto com a mão-de-obra africana (GOMES, 2015). Importante notar que a população indígena era muito numerosa nesse período. Segundo Darcy Ribeiro (1995, p.31): "Somavam, talvez, 1 milhão de índios, divididos em dezenas de grupos tribais (...) Não era pouca gente, porque Portugal àquela época teria a mesma população ou pouco mais”

Em relação à “articulação” cultural, foram intensas as trocas musicais entre portugueses e índios, principalmente, a partir da chegada dos jesuítas em 1549. No entanto, o olhar europeu neste embate frequentemente esteve ligado a questões exploratórias:

Para os homens brancos, a música indígena interessava não somente como
uma curiosidade para livros de viagens exóticas, mas também para se
conhecer melhor o costume dos índios e saber lidar com eles. Por outro lado,
a música europeia foi inicialmente cantada pelos índios também como
curiosidade, mas sem saberem que com esta música estavam se entregando à
deculturação. (CASTAGNA, 2010, p.45)

Ao mesmo tempo, para os diferentes povos africanos que foram escravizados, a chegada dos portugueses ao Brasil significou a intensificação da prática do tráfico de pessoas, praticada desde 1432 pelos portugueses, e que alcançaria a marca estimada de 11 milhões de pessoas forçosamente retiradas do continente africano (ALBUQUERQUE/FILHO, 2006, p.39). Em 1550 chegavam ao Brasil os primeiros africanos escravizados destinados ao trabalho nos engenhos de cana-de-açúcar no Nordeste (LOPES, 2005, p.31). Em seguida, o tráfico se intensificou, e cada vez mais indivíduos foram retirados de suas famílias na África e levados ao trabalho forçado nos engenhos brasileiros em um primeiro momento - e nas jazidas 
de ouro, posteriormente. Naturalmente, esses indivíduos procuraram cultivar seus costumes mesmo em condições inóspitas. Segundo o sambista e pesquisador Nei Lopes (2005, p.31):

Com esses bantos de Angola, do Congo e regiões subjacentes vieram seus "batuques", termo genericamente aplicado pelos portugueses aos ritmos e danças dos africanos. Batuques impregnados de um saber ancestral (...). Na tradição banta e negro-africana em geral, a canção desempenha papel relevante porque o material sonoro com que ela opera tem consequências importantes, tanto no plano cósmico quanto no da atividade cotidiana.

Portanto, paralelamente ao sofrimento causado pelos crimes da escravidão, os variados povos africanos (principalmente os dos reinos de Daomé, Oyo, Ndongo e Ketu) procuraram se reinventar no continente americano, ainda que submetidos ao trabalho compulsório, ao açoite e à chibata:

Os primeiros africanos nas Américas foram pioneiros, adaptando linguagens, moradias, alimentação, idiomas e culturas (...). Trabalharam demais, receberam castigos e maus-tratos sem cessar, e conheceram índices de mortalidade altíssimos. Mas o mar de dor da exploração a que foram submetidos fez também encontro com os oceanos culturais (...) em margens sem fins que eles forjaram. (GOMES, p.8, 2015)

Lopes (2005, p.33) defende terem sido as contribuições dos povos africanos o fator determinante da construção da música popular nas Américas. Em suas palavras “desses batuques (...) se originaram os principais traços musicais definidores da Diáspora Africana”.

Menos divulgadas, porém igualmente dignas de destaque, foram as trocas culturais entre índios e negros. Segundo Gomes (2015), em áreas de fronteiras ou mineradoras têm-se evidências de povos indígenas misturados com grupos africanos, dentre eles carijós, waiampis, caiapós, tiriós, xavantes, waianas e guaicurus.

Num acampamento quilombola foram apreendidos arcos, flechas, colares, vasos de barro, instrumentos musicais como pandeiro (...). No Mato Grosso (...) apareceu o grande quilombo do Quariterê, depois conhecido como Piolho. Por volta de 1770 ele foi atacado e destruído, e foram capturados entre homens, mulheres e crianças mais de cem quilombolas, sendo trinta índios. (GOMES, 2015, p.59)

Portanto, desde a chegada dos portugueses às terras brasileiras o processo de “articulação” de culturas se deu de forma intensa, sob a perspectiva das variadas combinações entre as matrizes culturais apresentadas. 
Outro momento de relevante importância para o recrudescimento deste caldeirão cultural brasileiro foi a transferência da corte real portuguesa para o Brasil, introduzindo na colônia costumes até então inéditos e intensificando a dinâmica cultural. Motivada, sobretudo, pelas ameaças de Napoleão, a vinda de D. João e da família real (composta ainda por sua mãe, a princesa Carlota Joaquina e seus filhos) em 1808 - um caso pioneiro de colônia sediando a corte - gerou importantes desdobramentos na “articulação” de culturas em nosso território, uma vez que catalisou os enfrentamentos culturais. Segundo Monteiro (2010, p.81): “O período colonial brasileiro foi uma das épocas mais instigantes da História do Brasil, sobretudo as práticas culturais, resultantes de uma miscigenação forte e diversificada (...). Não tínhamos ainda sido tão europeus”.

As transformações no contexto musical brasileiro imediatamente foram sentidas, com a implementação de novas práticas musicais, novas instituições e novas organizações profissionais. Monteiro (2010, p.90) destaca que "O surgimento de instituições de corte, com a Capela e a Câmara Reais, favoreceu a expansão da atividade musical, criou mais oportunidades e redefiniu a hierarquia entre os músicos”. As drásticas transformações se fizeram sentir até mesmo no perfil sociocultural dos músicos, uma vez que no período joanino se notou a substituição de uma mão-de-obra predominante mestiça por uma mão-de-obra branca, chegando a um contexto com $70 \%$ dos músicos de origem europeia (MONTEIRO, 2010).

No entanto, o viés dominador dos portugueses se impôs apenas nas práticas musicais palacianas. Ainda que sob a mira do eurocentrismo, nas ruas predominou o inevitável vigor da mistura cultural. Monteiro discorre sobre essa riqueza cultural:

No Brasil colonial, Apolo e Dionísio se entrecruzaram entre lundus, modinhas, batuques, práticas de feitiçaria, alegorias e Te Deuns (...) o Brasil, mais precisamente o Rio de Janeiro, se tornou uma sociedade que tinha pajés, reis do Congo, D. Maria I e D. João XI; transformou-se num espaço de ritos, onde deuses de várias naturezas disputavam as almas tropicais. Criou-se um círculo de articulações e um espaço de tolerâncias (MONTEIRO, 2010. P.107).

A miscigenação cultural tornou-se então uma característica determinante de nossa constituição social, alcançando complexos níveis de troca. A primeira ocasião em que um brasileiro foi à Europa especificamente para uma turnê de apresentações musicais ilustra o nível dessas trocas, posto que tais apresentações foram realizadas pela cantora Maria Joaquina da Conceição da Lapa, negra e escrava, em 1794, com um repertório de árias de óperas 
(CASTAGNA, 2010). Outro curioso indicativo da intensidade das trocas culturais, marcada por fluxos e refluxos, é apontado por Tinhorão (1998, p.111), segundo o qual o Fado, estilo musical icônico da cultura portuguesa, teria surgido no Brasil, a partir do Lundu, e se modificado em Portugal: “(...) os pontos coincidentes entre as duas danças são tantos, que quase se poderia pensar no fado como um segundo nome para o lundu”. O próprio Tinhorão (1998, p.118) aponta o caminho histórico pelo qual o Fado brasileiro teria se modificado em Portugal:

\begin{abstract}
A verdade é que, levadas para Portugal (...) as danças do Fado - acrescidas da contribuição melódico-sentimental das cantigas de "pensamento verdadeiramente poético" (...) - iriam percorrer caminho próprio nas camadas baixas de Lisboa, onde os brancos as tomariam dos pretos e mestiços para lhes transformar a parte cantada em canção urbana a partir da segunda metade do século XIX. Isso foi conseguido pelos malandros lisboetas - chamados de fadistas - através da mudança da afinação fundamental da guitarra portuguesa de doze cordas para ré menor, que lhes permitia acompanhar melhor os improvisos (...), e que logo evoluiriam para a glosa de quadras fixas (...) desde logo conhecidas como fados.
\end{abstract}

Para Ribeiro (1995, p.19), a intensidade das trocas foi tão radical que fez surgir um novo povo: "Novo porque surge como uma etnia nacional, culturalmente diferenciada de suas matrizes formadoras, fortemente mestiçada, dinamizada por uma cultura sincrética e singularizada pela redefinição de traços culturais delas oriundos”.

No entanto, diante deste cenário os povos dominados frequentemente precisaram lançar mão de estratégias de defesa - como o sincretismo - para preservar suas vidas ou seus valores. Monteiro (2010, p.108) utiliza o conceito de sincretismo no contexto afro-americano como:

(...) uma maneira de preservar a própria cultura em detrimento das interferências e das imposições da cultura europeia (...). Numa sociedade escravista e preconceituosa em tudo, esse sincretismo era a única forma possível de preservar o que é seu sem cair nas malhas da vigilância da Igreja e do Estado.

A questão do sincretismo irá se refletir inclusive na caracterização dos gêneros musicais por seus próprios compositores. Esse fato influenciará o uso de nomes de estilos musicais europeus, como Polca ou Tango, em composições da época, mesmo quando já se tratavam de outros estilos, como Maxixe ou Lundu, estes, então, malvistos pela alta sociedade. Os compositores recorriam a esse subterfúgio como forma de valorizar o status de 
suas composições ou até mesmo para que estas fossem aceitas comercialmente sem maiores restrições.

Portanto, a constituição cultural do país está, naturalmente, em relação direta com sua constituição sócio-histórica, em que o enfrentamento de diferentes tipos culturais - ou a forma como as contribuições se articularam e os sincretismos a partir dela surgidos - é fator determinante na construção do capital cultural brasileiro. Tal articulação está intensamente presente, também, na formação do Choro e dos regionais de Choro e no desenvolvimento da performance violonística no Brasil. Nas secções seguintes essa tendência cultural será apresentada.

\subsection{O CHORO}

A origem da palavra Choro, no contexto musical, tem sido alvo de muitas controvérsias e, portanto, existem variadas versões para a sua origem. Segundo o pesquisador Câmara Cascudo em seu Dicionário do Folclore Brasileiro (1982 apud CAZES, 1998), o termo Choro é uma derivação da palavra Xolo. Nas palavras de Cascudo: “os nossos negros faziam em certos dias, como em São João, ou por ocasião das festas nas fazendas, os seus bailes, que chamavam de xolo, expressão que, por confusão com a parônima brasileira, passou a dizer-se xoro e, chegando à cidade, foi grafada Choro, com ch”.

No entanto, no período colonial se popularizaram as Choromeleiras, importantes corporações musicais que recebiam esse nome por executarem as charamelas (uma espécie de clarinete pastoril, originário da Eurásia) e outros instrumentos de sopro, como fagotes e clarinetes. Nesta perspectiva, uma versão diferente para a origem da palavra Choro é utilizada por Ary Vasconcelos (apud BARBOZA, 2001, p.8) “o povo passou a chamar qualquer conjunto instrumental de choromeleiros”, expressão que acabou simplificada como Choros.

Há ainda, ao menos, mais duas versões para a genealogia da palavra. Em sua Pequena História da Música Popular, o pesquisador José Ramos Tinhorão (1998) remete à melancolia dos baixos do violão para justificar o nome Choro. Segundo Tinhorão, a melancolia evocada pela plangência grave dos bordões remeteria ao choro. No entanto, Cazes (1998, p.19) se opõe à essa interpretação e sugere que uma forma específica de executar as melodias é que pode ter dado origem ao termo: 
Quanto à melancolia das baixarias do violão, pelo que pude observar nas primeiras gravações de grupos de Choro, realizadas por volta de 1907, (...) o violão ainda não era usado com a exuberância com que hoje estamos habituados. Portanto, se algo evocava melancolia, era a maneira de tocar a melodia. Sendo assim, acredito que a palavra Choro seja uma decorrência da maneira chorosa de frasear, que teria gerado o termo chorão, que designava o músico que "amolecia" as polcas.

De forma análoga, controversas também são as datas relacionadas ao surgimento do gênero. Naturalmente, datar o surgimento de um gênero musical normalmente não é tarefa simples, ou mesmo, possível. No entanto, muitos pesquisadores têm na figura de Joaquim Callado (1848/1880) o detentor de certa paternidade histórica sobre o Choro.

O pesquisador André Diniz (2008), em texto produzido para o encarte da publicação Joaquim Callado: o pai dos Chorões, relata que em 1967 o maestro Batista Siqueira escrevera o livro Álbum de Músicas Imperiais, com a recuperação de composições populares do período colonial. Segundo Diniz (2008, p.58), essa publicação apresentava o seguinte comentário a respeito do surgimento do Choro: “O conjunto [refere-se ao Choro] é típico da Guanabara e surgiu das atividades de dois excelentes flautistas: Callado e Viriato”. Embora apareça em companhia do flautista Viriato nessa publicação, Callado é apontado individualmente como o criador do gênero em muitos outros estudos. José Ramos Tinhorão (apud DINIZ, 2008 p.60) tem a seguinte opinião sobre o tema:

Quando, na segunda metade do século XIX, o flautista carioca Joaquim Antônio da Silva Callado passou a tocar acompanhado por dois violões e um cavaquinho, estava longe de imaginar que seria - se não o criador - pelo menos o pioneiro historicamente localizável do grupamento musical de música popular mais resistente do mundo.

O próprio Batista Siqueira em publicação posterior, individualiza a paternidade do Choro, atribuindo-a exclusivamente a Callado:

Contudo, já sabemos, com certeza, que as "polcas de serenata” que deram por fenótipo o Choro, estão relacionadas com a figura simpática e atraente do imortal flautista Callado... Como chegamos a esta informação? Porque, nas várias buscas efetuadas, encontramos em mão de um seu neto (...) duas polcas inéditas, uma delas sem nome, que era obra escrita para Choro. A referida peça oferece, de fato, as dificuldades modulantes próprias do estilo e tem o nome sugestivo de Perigosa. (SIQUEIRA, 1969 apud DINIZ, 2002, p.58). 
Cazes (1998, p.19), por sua vez, tem uma visão um pouco diferente, embora não necessariamente contraditória, para o surgimento do estilo. Segundo ele, a data está associada à chegada da Polca ao Brasil: "Se eu tivesse que apontar uma data para o início da história do Choro, não hesitaria em dar o mês de julho de 1845, quando a Polca foi dançada pela primeira vez no Teatro São Pedro”.

De fato, é muito importante observar a relação entre o Choro e as danças europeias como a Valsa, a Mazurka e o Schottish e, em particular, com a Polca. As melodias dessas danças, normalmente adaptadas pelos músicos brasileiros influenciados, provavelmente, pela rítmica africana, deram origem aos primeiros materiais melódicos do Choro. Sobre o abrasileiramento dos ritmos estrangeiros, Marília Barboza defende que a Polca tenha sido o grande eixo musical unificador da música popular brasileira nesse período:

Foi em torno da Polca que, na década de 70 do século dezenove, cristalizaram-se quase todos os gêneros da nossa música popular. O batuque, o jongo e o lundu, de origem africana; a valsa, a mazurca, a xótis, o tango, de procedência europeia; e a habanera cubana fundiram-se todos com a polca, originando a polca-lundu, a polca-batuque, a polca-tango, a polca-fadinho, etc. (BARBOZA, 2001, p.12).

De fato, o reinado da Polca no Brasil foi extenso. Provavelmente por estar em consonância com os anseios liberais da sociedade do Rio de Janeiro, uma vez que nessa dança os casais mantinham um contato físico mais evidenciado. Segundo Diniz, a Polca se encaixou perfeitamente às necessidades sociais e em suas palavras:

(A Polca) pôs de lado as danças da época - como as quadrilhas e os minuetos - que mantinham os pares separados. Agora tanto as damas e cavalheiros da Corte Imperial quanto das camadas médias da sociedade, podiam usufruir da intimidade que chegava com os pulinhos da nova dança. (DINIZ, 2002, p.15),

Tinhorão aponta outros elementos que podem ter favorecido o sucesso da Polca:

Na verdade, a polca inaugurava nos salões dos ricos e nas salas de visita dos remediados o ritmo 2/4 em allegretto, o que comunicava aos dançarinos uma vivacidade inédita, tão coerente com o momento de euforia econômica, destinado a culminar com o superávit da balança comercial brasileira a partir de 1860. Essa vivacidade de ritmo - que por si só já denunciava uma explosão de individualidade absolutamente nova - vinha sendo anunciada desde o início do século XIX pelas quadrilhas. (TINHORÃO, 1998, p.60) 
Portanto, quando se tornou uma espécie de mania nacional, após sua chegada, na década 1840, a Polca sofreu alterações no território brasileiro, sucumbindo à inevitável presença da cultura africana ${ }^{3}$ (SANDRONI, 2001). Em relação às transformações sofridas pela Polca, muitos pesquisadores (DINIZ, 2002) apontam forte influência do Lundu em tais inovações.

O Lundu, por sua vez, teria se originado dos “batuques” africanos ${ }^{4}$, e normalmente é caracterizado como uma dança de roda angolana ${ }^{5}$, em que estão presentes os atabaques e a umbigada $^{6}$. Castagna (2010, p.16) defende que a origem do Lundu está atrelada a um hibridismo entre elementos ibéricos e africanos. Segundo Marcílio (2009, p.64), “como células predominantes, já figuravam no lundu as células rítmicas
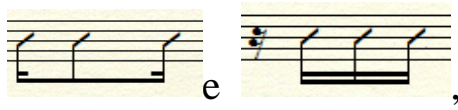
, como se vê no exemplo Isto é bom de Xisto Bahia”.

Figura 1 - Isto é bom

${ }^{3}$ Diniz aponta a década de 1870 como o período de diferenciação da música brasileira: "Enquanto o Rio de Janeiro se modernizava, a música popular percorria um caminho que levaria à sua nacionalização. Ainda não era brasileira; apenas esboçava formas que só neste século iriam tornar-se mais definidas. Portanto, é a partir de 1870 que podemos falar de uma cultura melaninada, onde o pigmento fundamental a singularizá-la foi o do elemento negro. Isso foi possível porque a cultura negra manteve-se vigorosa através da preservação da religião... (DINIZ, 2008, p.81).

${ }^{4}$ Araújo (apud SANDRONI, 2001, p.42) evoca uma explicação sócioafetiva para o seu surgimento: “o lundu (...), descendente direto do batuque africano, foi a válvula de equilíbrio emocional que se utilizaram os escravos para amenizar as agruras do exílio e os sofrimentos da escravidão”.

${ }^{5}$ Sandroni (2001), no entanto, aponta para origens ibéricas.

${ }^{6}$ Sobre a relação entre Dança e Música, Carvalho (2006, p. 38-39) aponta que: Atrás do gesto, do movimento, vem a música, aliás, seguindo uma tradição africana, onde não só os músicos estimulam à dança, mas também os bailarinos transformam a música, através de um diálogo improvisado. Assim nasce o maxixe. Apesar do preconceito da sociedade da época, contra sua dança indecente (que na verdade estava muito mais relacionado à sua origem mestiça e pobre), o maxixe se desenvolve, passa a ser executado nos teatros e salões da alta sociedade, e divulgado nas casas de família através das partituras editadas para piano. 


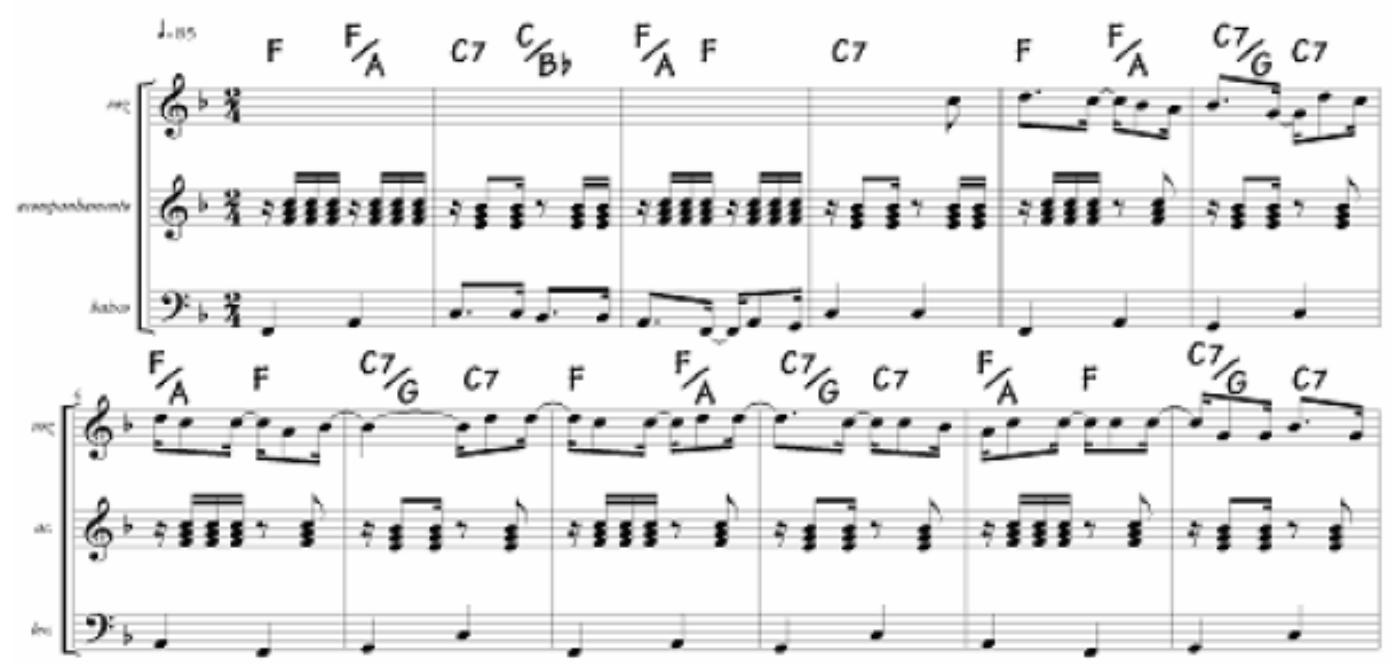

Fonte: Isto é bom (Xisto Bahia), PAES/ARAGÃO, 2006.

Tais células alterariam significativamente a Polca e viriam a constituir material rítmico fundamental do Choro, tanto nas melodias quanto nos acompanhamentos, como será apresentado mais adiante.

Nesta perspectiva, podemos observar relatos de pesquisadores que defendem ter também o Choro seguido essa mesma linha de constituição, uma espécie de "nacionalização" da música europeia:

O choro é visto como o recurso do qual se utilizou o músico popular para executar, ao seu estilo, a música importada e consumida nos salões e bailes da alta sociedade do Império a partir da metade do século XIX. Sob o impulso criador e improvisado dos chorões, logo a música resultante perdeu as características dos seus países originários e adquiriu feições genuinamente brasileiras (DINIZ, 2008, p.14).

Ou ainda:

O Choro surgiu no Rio de Janeiro, na segunda metade do século XIX, a partir de um jeito "sentimental" com que grupos populares - formados por flautas, violões e cavaquinho - abrasileiraram estilos musicais que aqui chegaram da Europa em fins da primeira metade do mesmo século. A valsa, o schottisch, a mazurka e, em especial, a polca misturaram-se ao nosso lundu e à modinha e acabaram por receber uma forma peculiar de interpretação e composição. (SÉVE, 2014, p.1148)

Portanto, é possível admitir que músicas europeias e africanas podem ser tidas como substratos musicais do Choro, personificados, em certa medida, na figura de Joaquim Callado. Sobre esse tema, assim Diniz se pronuncia: 
Foi da fusão do lundu africano que os gêneros estrangeiros do século XIX, sobretudo a Polca, foram caracterizando nossa cultura musical, tornando-se seus filhos diletos o Choro e o Maxixe. Já percebemos que o flautista Callado foi um dos personagens de destaque de criação e divulgação de “novos ritmos”. Em 1879, Ele não só já havia composto o lundu como já havia, também, consolidado seu nome no meio musical. (DINIZ, 2008, p.24)

Paralelamente à figura de Callado e da enorme importância das danças europeias e da força rítmica africana, outros três grandes músicos também são conhecidos como alicerce do Choro: Anacleto de Medeiros, Chiquinha Gonzaga e Ernesto Nazareth.

O músico Anacleto de Medeiros (1866/1907) é considerado o grande “abrasileirador” do Schottish e um grande compositor do gênero. Seu Schottish Iara foi utilizado por VillaLobos na sua obra Choro n.10. O instrumentista ficou famoso também como regente e arranjador da banda do Corpo de Bombeiros, responsável pelas primeiras gravações de Polcas, Dobrados, Tangos, Valsas e outros ritmos europeus tocados com sotaque brasileiro (LEME, 2006). Muitos de seus Choros são tocados ainda hoje pelos chorões, dentre eles:

\section{Três Estrelinhas e $\mathbf{O}$ Boêmio.}

Chiquinha Gonzaga (1847/1935) foi a primeira chorona e a primeira "pianeira" brasileira. Ela lutou pelo direito de poder tocar profissionalmente em um ambiente patriarcal e autoritário. Segundo Marcílio, Gonzaga e o Maxixe estão associados ao preconceito e à marginalização.

(...) a biografia de Chiquinha Gonzaga foi permeada de tumultos, fundamentalmente ligados à suas incompatibilidades ideológicas com seu período. Teve que vencer fortes preconceitos, e a liberdade que tanto buscava, a fez enfrentar muitos escândalos: por ser mulher, artista, mestiça, separada do marido, e ainda desempenhar uma profissão para sustentar-se, característica de boêmios e vagabundos. (MARCÍLIO, 2009, p.20).

Segundo Cazes (1998, p.36), a compositora "lutou pela sobrevivência, lutou pela abolição da escravatura, lutou para ver a música mestiça dos chorões tocada e respeitada nos salões elegantes”. Vários choros de sua autoria são, ainda hoje, executados, como o Corta-

\section{Jaca e Atraente.}

O pianista Ernesto Nazareth (1863-1934) conseguiu se destacar na música dita popular e na música dita erudita. Ele, nas palavras de Travassos (2000, p.14), “foi autor de uma obra original, extensa e tributária tanto dos chorões e das danças urbanas cariocas quanto do gosto europeu”. Leme (2006, p.50) também destaca o compositor, para ele “o pianista mais famoso 
da virada do século foi Ernesto Nazaré. Compositor prolífico é considerado o fixador do tango brasileiro, ganhou admiração de vários músicos de renome, até mesmo do meio erudito”. Nazareth formatou um estilo composicional que até hoje é referência, assim como sua obra é referência obrigatória para os chorões e para os pianistas brasileiros. Muitos de seus choros são ainda hoje celebrados nas rodas, como o Brejeiro, Odeon, Atlântico e Apanhei-te cavaquinho.

Ainda sob a perspectiva da consolidação do gênero Choro, é preciso observar a importante contribuição de outros dois agentes: a Música dos Barbeiros e as Bandas de Fazenda. Em relação à Música dos Barbeiros, o pesquisador André Diniz ponta que tais grupos eram formados por negros ainda escravizados:

(...) sendo formados, basicamente, por escravos obrigados por seus senhores a aprenderem novos ofícios. A profissão de barbeiro era a única a deixar tempo vago para a aprendizagem de outros trabalhos, daí a denominação dos grupos musicais. Os barbeiros se apresentavam em festas religiosas, profanas e até oficiais: tocavam dobrados, fandangos e quadrilhas. E era comum encontrar nos jornais notas ressaltando a qualidade musical de escravos à venda. (DINIZ, 2008, p.17)

O músico e pesquisador Ivaldo Lara Filho sugere que tais agrupamentos musicais eram formados por negros alforriados:

Os ternos de barbeiros eram formados basicamente por negros forros, que animavam festas populares. A formação instrumental consistia basicamente de violão, cavaquinho e flauta e, dependendo da ocasião, juntavam-se a eles trompetes, trompas e tambores de balde. Os repertórios (...) constituíam-se basicamente de Modinhas, Lundus e Fados. (LARA FILHO, 2009, p.8).

Desta forma, ele distingue as Bandas de Barbeiros das Bandas de Fazenda, sendo que estas últimas seriam formadas por negros ainda em situação de escravidão: “As Bandas de Fazenda eram grupos formados por negros escravos que, influenciados pelas tendências urbanas, tentavam reproduzir aquela música com instrumental e repertório similar à música dos barbeiros” (LARA FILHO, 2009, p.8).

No entanto, no dia 23 de abril do ano de 1897 nascia o músico que iria consolidar o Choro e elevar definitivamente o seu status: Alfredo da Rocha Vianna Filho, popularmente conhecido como Pixinguinha. Desde muito cedo, Pixinguinha assombrou o mundo do Choro com seu virtuosismo e sua criatividade na maneira de tocar a flauta. Segundo Cazes (1998, p.53): "Pixinguinha foi demonstrando sua vocação para o improviso e acrescentando umas 
"bossas” que não estavam na partitura”. Além disso, sua forma de tocar se diferenciava, visivelmente, daquela utilizada pelos flautistas tradicionais da época. Pixinguinha valorizava a rítmica, e segundo DIAS (apud CAZES, 1998, p.54) sua forma de utilizar o instrumento era diversificada, pois ele: “gerava um som com muito ar, em golpes enérgicos”.

Em 1915, aos 13 anos Pixinguinha já tocava profissionalmente, e aos 18 anos já gravava uma composição própria, chamada Dominante. Logo em seguida, suas composições passaram a ser gravadas mais frequentemente, e seu estilo de composição inovador foi sendo revelado em composições como Rosa, Sofres Por Que Queres e Os Oito Batutas, o que contribuiu radicalmente para a formatação do gênero. Para Cazes (1998, p.57): "Partindo da música dos chorões e misturando elementos da tradição afro-brasileira, da música rural e de sua variada experiência profissional como músico, Pixinguinha aglutinou ideias e deu ao Choro uma forma ${ }^{7}$ musical definida”.

Os Oito Batutas, além de nome de uma de suas composições, seria também o nome de um de seus conjuntos, e é considerado o primeiro deles a, realmente, fazer fama no Brasil e no exterior. Além de flautista virtuoso, Pixinguinha foi ainda um talentoso e inventivo arranjador, preocupado em encontrar uma linguagem brasileira de orquestração e instrumentação. Durante essa procura, Pixinguinha desenvolveu linguagem inovadora, e elevou a importância da percussão nos arranjos orquestrais. Segundo o maestro Guerra Peixe (BARBOZA e OLIVEIRA apud CAZES, 1998, p.77): "Pixinguinha deve ser encarado como um ponto de partida pelos orquestradores brasileiros. Seus trabalhos nessa especialidade deixam transparecer valores típicos da nossa música popular, seja em harmonia, em contraponto, ritmo e feição regional”.

Não bastassem tantas contribuições superlativas nas áreas da performance solista, da composição e da orquestração, o mestre Pixinguinha deixou, ainda, um importante legado no que se refere à linguagem dos contrapontos, que seria determinante para o desenvolvimento do violão brasileiro. Isto pode ser observado, principalmente, no final de sua carreira, quando Pixinguinha fez dupla com o flautista Benedito Lacerda. Nesse acordo, em que o solista principal seria o Benedito, o mestre passaria à coadjuvante, tocando o sax tenor. No entanto, com sua genialidade, e seus arrebatadores contrapontos, Pixinguinha conseguiu se sobressair nas gravações, recebendo importância maior que o próprio solista, Benedito Lacerda. Tais contrapontos, além de extremamente importantes para quem deseja estudar uma forma

\footnotetext{
${ }^{7}$ Imagino que ao usar a palavra "forma” o pesquisador não esteja remetendo a aspectos estruturais (como a forma Rondó, por exemplo) e sim à aspectos composicionais.
} 
brasileira de concebê-los, foram de crucial importância, alguns anos depois, para a consolidação dos contrapontos violonísticos, as famosas "Baixarias". Segundo o violonista e pesquisador Maurício Carrilho, em depoimento a Chediak (2009, p.41): no Songbook de Choro, "O Dino tocou muito tempo com o Pixinguinha, ouvindo os contracantos. Eu nunca ouvi o Dino falar disso, mas acredito que isso tenha sido uma grande referência para ele e ele passou para a linguagem do violão muita coisa que o Pixinguinha tinha trazido...”.

A importância de Pizindim (como Pixinguinha era chamado por sua avó) para a Música Brasileira levou o musicólogo Ary Vasconcelos (apud PESSOA, 2012, p.55) a proferir: "Se você tem quinze volumes para falar de toda música popular brasileira, fique certo de que é pouco. Mas se dispõe apenas do espaço de uma palavra, nem tudo está perdido; escreva depressa: Pixinguinha”. Muitos dos Choros de Pixinguinha fazem parte, vivamente, dos repertórios atuais, seja em Rodas de Choro, seja em gravações - como Lamentos, Rosa, Carinhoso, Um a zero, Ainda me recordo. É muito raro presenciar uma Roda de Choro em que não se ouçam algumas composições de Pixinguinha. No dia 23 de abril, data de seu nascimento, é comemorado o Dia do Choro em todo o território nacional.

\subsection{O REGIONAL DE CHORO}

Com os portugueses vieram a guitarra (violão), o cavaquinho, a viola, a flauta, o oficleide, o piano e o grupo das cordas. Acredita-se que o cavaquinho tenha surgido na Espanha, derivado de um "guitarro andaluz", como instrumento de ritmo e harmonia. O violão e a viola, da mesma família, teriam vindo de longa jornada desde a cítara. Aliados à flauta, esses instrumentos já eram, no fim do século XVII, a base da formação costumeira entre os músicos populares (...). Os grupos formados por violão, cavaquinho e flauta eram conhecidos no fim do século XIX como "pau-e-corda", nome que se explica pelo fato de as flautas utilizadas na época serem de ébano (PELLEGRINI, 2005, p.32).

Pellegrini destaca acima a importância da colonização portuguesa na definição daquilo que seria a instrumentação da música brasileira no início do século XX.

A partir dessas combinações instrumentais, por volta de 1870, em seu conjunto Choro Carioca, Callado disseminava o embrião da formação típica de Choro: flauta, cavaquinho e violões. Nas palavras de Barboza (2001, p. 9): “Ficou famoso o Choro Carioca, conjunto inicialmente orientado pelo grande flautista Joaquim Antonio da Silva Callado (1848-1880), (...), constituído flauta, cavaquinho e dois violões”. Tal formação parecia atender 
perfeitamente às necessidades musicais e acústicas dessa proposta musical. Segundo Cazes (1998, p.47):

O quarteto formado por dois violões, flauta e cavaquinho surgiu naturalmente da busca de um melhor equilíbrio acústico entre o volume de uma flauta e um cavaquinho, instrumentos que atuam do médio para o agudo, com as frequências médias e graves do violão. Essa formação foi batizada por Batista Siqueira de "quarteto ideal" e esteve presente na base de todo grupo de Choro, sempre com dois ou três violões (muito comumente, um deles de sete cordas).

Além das questões acústicas e musicais, a "desenvoltura prática” desse perfil de músicos foi de grande importância para a consolidação dos Regionais, sobretudo na época áurea do rádio. O casamento entre esses músicos e o rádio ocorreu na primeira transmissão radiofônica no Brasil, em 07 de setembro de 1922, nas comemorações da Independência:

Essa presença pioneira marcou o início de uma parceria que, nos trinta anos seguintes, seria um elemento fundamental para o desenvolvimento da música popular no Brasil: os regionais e o rádio. A evolução, desde o final do século XIX, dos trios de choro (flauta, violão e cavaquinho) foi à base do que passou a ser chamado de "conjuntos regionais". (PRATA, 2005).

Após essa aproximação, o formato dos Regionais demonstrou possuir características apropriadas aos anseios da estrutura radiofónica:

A aproximação com os grandes cantores de samba, principal gênero popular da época; a versatilidade para acompanhar calouros, já que os músicos de Choro eram mestres no acompanhamento "de ouvido"; uma bem-vinda praticidade, pois não necessitavam de arranjos escritos, bastando saber o tom da música e acertar a introdução, além de um inegável virtuosismo, quando se tratava de apresentar o seu repertório de choro, fizeram dos regionais a formação musical ideal para a radiofonia brasileira, ainda no seu início. (PRATA, 2005).

Tal instrumentação, muito próxima àquela disseminada no grupo de Callado, consolidou-se, então, desta forma: instrumento solista, sopro ou cordas; instrumentos harmônicos: cavaquinho e 2 (ou 3) violões; e instrumento de percussão: pandeiro. O mesmo Sérgio Prata assim define a instrumentação:

No solo, uma flauta, bandolim ou clarinete dando a introdução para os cantores; na harmonização, um cavaquinho e dois violões fazendo contracantos em "terças", ou em "sextas", alinhavados pelo ritmo de um pandeiro de atuação discreta indicavam qual seria o formato a seguir. (PRATA, 2005). 
Vários regionais se valeram e ainda se valem dessa formação. Nesta pesquisa, o conceito de Regional ${ }^{8}$ é utilizado para designar esse tipo de arregimentação. $\mathrm{O}$ violonista Marco Pereira (2007, p.42) define o Regional como “o ensemble instrumental tipicamente carioca que definiu a maneira de tocar Choro”. Nessa composição, o Conjunto Época de Ouro, por exemplo, utilizava como solista, normalmente, o bandolim (Jacob do Bandolim) e, em raras exceções, o violão tenor ou outro instrumento convidado. No entanto, a flauta, o clarinete, a sanfona, o cavaco (solista) e o sax, dentre outros, também são percebidos como opções de solista em outros regionais. A função principal do solista, naturalmente, é realizar as melodias. O solista pode ainda realizar contracantos em trechos em que a melodia for realizada por outro instrumento. São muitos os solistas a se destacarem no Choro. Citá-los é uma grande dificuldade, pois alguns podem ser esquecidos, o que seria injusto. Contudo, como ilustração, dentre excelentes músicos alguns nomes são referência no bandolim: Jacob do Bandolim, Luperce Miranda, Izaías, Rossini Ferreira, Cincinato, Ronaldo do Bandolim, Déo Rian, Hamilton de Hollanda, Jorge Cardoso, Danilo Brito; na flauta: Callado, Pixinguinha, Altamiro Carrilho, Carlos Poyares, Copinha, Bide, Odette Ernest Dias, Eduardo Neves; na clarineta: Abel Ferreira, Paulo Moura, Paulo Sérgio Santos, Nailor Proveta; no cavaco solo: Waldir Azevedo, Henrique Cazes, Eli do Cavaco, Jacaré; na sanfona: maestro Chiquinho, Oswaldinho, Orlando Silveira; no piano: Ernesto Nazareth, Chiquinha Gonzaga, Radamés Gnattali.

Os violões, por sua vez, realizam a função harmônica, a função contrapontística e a função rítmica. Normalmente, um regional de Choro possui um violão 7 cordas e um violão 6 cordas (em alguns momentos, os regionais possuíram 2 violões de 6 cordas). Essa composição instrumental e a interação presente nessa formação são temas desenvolvidos no capítulo seguinte. Eles têm um espaço especial nesta pesquisa que inclui a menção a violonistas importantes e marcantes.

\footnotetext{
${ }^{8}$ A origem do nome Regional nesse contexto de grupo musical é atribuída às caracterizações de vestuário folclórico utilizado pelos grupos musicais no final dos anos 20, como os Turunas Pernambucanos, os Turunas da Mauricéia e o grupo do Caxangá. É sabido que alguns músicos preferiram outras denominações, sobretudo a partir da década de 60, como por exemplo, o Conjunto Época de Ouro ou o Conjunto Noites Cariocas. Da mesma forma, é sabido que mesmo aqueles grupos que se intitularam de Regionais, só o fizeram a partir da Era do Rádio (aproximadamente 1930), quando o termo surgiu. No entanto, por questão de comodidade (e uma vez ressalvadas as questões acima) o termo Regional é utilizado, durante a exposição da pesquisa, quando esse tipo de formação é mencionado de forma genérica.
} 
O cavaco, ou cavaco centro, tem a híbrida função rítmico-harmônica. Simultaneamente, ele é responsável por realizar a harmonia (na região aguda) e por auxiliar o pandeiro na condução rítmica. Em sua pesquisa “Tradição e Inovação no Cavaquinho Brasileiro”, o músico Luís Carlos Orione (também conhecido como Carrapa do Cavaquinho) assim escreve a respeito do hibridismo do instrumento: "O modo de tocar cavaquinho brasileiro é uma mistura de Europa e África onde na mão esquerda, se faz os acordes tonais vindos do velho mundo e na mão direita pode-se sentir o rufar dos tambores africanos”. (CORRÊA, apud ORIONE, 2015, p.15).

Dentre muitos outros, destacaram-se como grandes cavaquinistas em regionais de Choro: Nelson Alves, Jonas, Canhoto, Garoto, Luciana Rabello e Evandro Barcellos.

O pandeiro é o principal instrumento da seção rítmica. Junto com o cavaco, é o responsável pelo "balanço" do regional. O pandeirista precisa conhecer as melodias, as variações rítmicas típicas de cada trecho do Choro e os “breques” de obrigação. Nas palavras de Pellegrini, questões práticas auxiliaram a consolidação do instrumento nessa formação:

Também por questão de equilíbrio e praticidade, o pandeiro foi, dentre esses instrumentos, o que mais se adaptou ao "quarteto ideal". Em sua batida básica, o percussionista marca os tempos com o polegar, ressaltando o som grave do couro e, com as pontas dos dedos e a base da mão, marca as subdivisões desse tempo batendo próximo ao aro, ressaltando os sons agudos das platinelas. Dessa forma, tem-se, em um só instrumento, o grave e o agudo, a marcação do tempo e suas subdivisões. Perfeito para a "orquestra de bolso" que vinha se desenvolvendo nas últimas décadas e que se mantém até os nossos dias como a base do choro. (PELLEGRINI, 2005, p.34).

Tem-se o lendário músico João da Baiana como o responsável pela introdução do pandeiro no Samba e no Choro. Seu depoimento prestado ao Museu da Imagem e do Som reforça essa ideia: "na época o pandeiro era só usado em orquestras. No samba quem introduziu fui eu mesmo. Isto mais ou menos quando eu tinha oito anos de idade (...). O pandeiro não era igual ao atual. O dessa época era bem maior". (CASA DO CHORO, 2013).

A essa altura, o pandeiro era ainda instrumento marginalizado, como conta o próprio João da Baiana, no mesmo depoimento ao MIS: “O Samba era proibido, o pandeiro era proibido. Então a polícia perseguia a gente. (...) Eu tocava pandeiro na Penha, na época da Penha, a polícia me tomava o pandeiro”. Podemos observar a perseguição sofrida pelo instrumento neste outro depoimento: 
O senador Pinheiro Machado, que era seu admirador e que frequentemente promovia festas em "seu" palácio no Morro da Graça, o convidou [João da Baiana] para uma dessas festas e como ele não apareceu, quis saber o por quê. Ao saber que o instrumentista tivera seu pandeiro apreendido, resolveu presenteá-lo com um novo padeiro, que trazia a seguinte inscrição: "Com a minha admiração, ao João da Baiana - Pinheiro Machado". Com essa dedicatória do senador, pode voltar por diversas vezes à Festa da Penha, como integrante do Grupo do Malaquias, sem que a polícia fosse atormentálo. (CASA DO CHORO, 2013).

Ou seja, diante desse cenário de marginalização, foi preciso uma autorização de um senador para que João da Baiana pudesse circular com tranquilidade com o seu instrumento, como uma espécie de salvo-conduto junto à polícia. Esta passagem ilustra a perseguição que os instrumentos, os instrumentistas e a Música Popular sofreram e ainda sofrem, em certa medida, no Brasil.

\title{
2.3 O VIOLÃO NO BRASIL
}

\begin{abstract}
Embora pareça que o instrumento tenha chegado anteriormente, notícias certas sobre viola de arame só apareceram de fato nas cartas dos jesuítas, que chegaram ao Brasil com Tomé de Souza em 1549. Foram eles que introduziram aqui, de modo sistemático, as violas e os demais instrumentos europeus. O instrumento tinha, então, 3 cordas duplas e a prima simples. No século seguinte iria ganhar mais uma ordem de cordas, e na segunda metade dos anos de setecentos, ainda mais outra. Transformou-se assim num instrumento de 6 cordas duplas, que se tornaram simples. Isso exigiu um aumento de tamanho para compensar o menor volume de som. Tornou-se, assim, viola grande. Ou violão (TABORDA, 2011, p. 41).
\end{abstract}

Neste contexto da viola, Domingos Caldas Barbosa (1738/1800) parece ter sido o grande divulgador do instrumento. Taborda afirma que a maioria dos pesquisadores brasileiros apontam Caldas como introdutor da Modinha e do Lundu na corte de D. Maria I (...) e "todos os estudiosos afirmaram que o veículo para a realização das manifestações de Caldas teria sido a viola, instrumento por ele mesmo tangido”. (TABORDA, 2011, p.46).

O surgimento do violão brasileiro e da viola caipira como instrumentos musicais parece estar diretamente ligado à tradição europeia das violas. Como descrito pela violonista e pesquisadora Márcia Taborda, a viola europeia se transformando musicalmente e acusticamente ao longo dos séculos, até receber o nome e o formato de Violão. A revista Nova Coleçao de Modinhas Brasileiras registra a utilização do violão nas Modinhas: 
Todos já cultivam a musica, pois que faz parte da existência do povo, que adoça os seus lazeres cantando, e que até esquece os cuidados de um penoso trabalho sempre que escuta os simples accordes de uma guitarra ou violão. (...). As mais das vezes encontram-se grupos numerosos de jovens que unem os sons do violão aos da flauta; são geralmeute pouco variados os seus accordes, mas sempre justos, e essas árias simples, repetidas com tanta doçura, enchem a gente de singular melancolia, sobre tudo no seio de uma bella noite dos trópicos. (NOVA COLECÇÃO DE MODINHAS BRAZILEIRAS, 1878, p.11).

Leme ressalta algumas características que podem ter contribuído para a rápida popularização dos instrumentos de cordas no Brasil nesse período. Tais características estão relacionadas ao peso, ao formato e ao custo destes instrumentos:

Instrumentos preferidos pelos colonos portugueses, leves, fáceis de carregar e de baixo custo, os violões, violas, cavaquinhos, etc., se adaptaram bem a dura realidade da colônia, e passaram a ser os instrumentos mais utilizados para a realização da harmonia e do baixo em todos os estilos da música popular brasileira. Facilmente adaptados às músicas com forte apelo rítmico, como as de origem afro-brasileira, esses instrumentos, acrescidos de percussão, formam até hoje, a base para as músicas de dança, nos regionais, conjuntos e orquestras pelo país. (LEME, 2006, p.53).

Em relação ao espaço de atuação do violão Taborda aponta que, ainda no século XIX, a viola e o violão passam por uma diferenciação social, assumindo ocorrências geográficas específicas. O primeiro vai ser identificado com a música regional, do interior e o segundo assume a identidade urbana da capital:

A partir da segunda metade do século XIX, quando a novidade do violão estava perfeitamente assimilada pela sociedade carioca, a viola assumiu identidade regional, interiorana. Ao violão coube o papel de veículo acompanhador das manifestações musicais urbanas, exercício alavancado pela verdadeira explosão de conjuntos musicais - os grupos de choro que surgiram e se difundiram pelos diversos bairros cariocas desde os meados daquele século. (TABORDA, 2011, p.57).

Pessoa (2012 p.41) concorda com essa tese e a reforça:

É nos grandes centros urbanos que o violão alcançará sua alcunha de instrumento nacional. Será ele o instrumento responsável pelo sotaque de Brasil dado às interpretações das Polcas, Valsas, Tangos e Schottisches dançados nos salões e na periférica Cidade Nova. Segundo Taborda, "este processo, denominado por alguns como o abrasileiramento das danças europeias, encontrou na voz do violão, e particularmente no ambiente musical dos chorões, o meio através do qual novas formas pudessem daí emergir” (2004, p.93). 
Cazes (1998, p.47), por sua vez, acrescenta que, mesmo antes do nascimento do Choro, o violão já conquistara a sociedade carioca, estava presente em diferentes manifestações populares e se despontava como instrumento acompanhador:

Muito antes do surgimento do Choro e da forma chorada de tocar, o violão já era um instrumento popular que acumulava uma grande participação em todo tipo de música feita fora das elites. Estava sempre presente no acompanhamento das serenatas, dos lundus, das cançonetas, na música dos barbeiros, enfim, tudo que se referia às atividades de música popular anteriores ao Choro. Com o surgimento da chamada música dos chorões, o violão, juntamente com o cavaquinho, formou uma base rítmico-harmônica que recebia os solistas: flauta, clarinete e outros;

Portanto, diante desse cenário, é possível afirmar que o Choro, como típica manifestação urbana, serviu como importante substrato musical para a popularização do violão no Brasil (embora a consolidação do instrumento já estivesse acontecendo) e viceversa. O Choro e o violão se alimentaram mutuamente, reforçando-se reciprocamente.

\subsection{O VIOLÃO NO CHORO}

O início da história do Violão no Choro se confunde com a história dos violonistas que a compuseram. Portanto, na presente secção procurei mapear alguns dos grandes violonistas que formataram a maneira de se tocar o Violão nos primórdios do Choro, bem como descrever suas principais contribuições para a performance no instrumento.

Pertencente à primeira geração de chorões, Sátiro Bilhar (1860/1926) foi contemporâneo de Villa-Lobos e João Pernambuco. Segundo o Dicionário Cravo Albin da Música Brasileira (DICIONARIO CRAVO ALBIN DA MÚSICA POPULAR BRASILEIRA, 2015). Villa-Lobos definiu a performance de Sátiro da seguinte forma: “(...) não era o que ele tocava, mas como tocava é que era genial”. Sua Polca intitulada Tira Poeira foi gravada por Jacob do Bandolim e ainda hoje é executada nas Rodas de Choro e apresentações.

Contemporâneo de Sátiro, e, portanto, também pertencente à primeira geração de violonistas chorões, Quincas Laranjeiras (1873/1935) também teve muito contato com o Violão Erudito, sendo apontado como um grande divulgador da Escola de Tárrega no Brasil. A revista Violão (1929), assim descreve o violonista: "Homem consciente, modesto e probo, fez disso sacerdócio, ministrando a seus discípulos seus criteriosos ensinamentos, (...). Pode- 
se por isso dizer com justiça que Quincas Laranjeira é o avô do violão moderno. A ele se deve mais que a qualquer outro os primeiros passos no estudo do violão”. Sua Valsa intitulada Dores D’alma é pioneira na utilização do efeito de arraste (deslize do dedo sobre a corda grave) que mais tarde se tornará característica marcante da obra do violonista Dilermando Reis.

João Pernambuco (1883/1947) mudou-se, aos 20 anos, de Recife para o Rio de Janeiro, e o costume de falar sobre sua terra lhe rendeu o novo sobrenome. Sua música também esteve fortemente carregada do sotaque sertanejo. Sua obra violonística alcançou um nível tão alto que Villa-Lobos assim se manifestou: "Bach não se envergonharia em assinar os estudos de João Pernambuco como sendo seus". Taborda (2011, p.49) destaca que a admiração levou Villa-Lobos a utilizar, em seu Prelúdio 5, o tema da Valsa Sonho de Magia, de João Pernambuco. A sua composição Luar do Sertão, letrada pelo poeta Catulo da Paixão Cearense ficou muito famosa, embora nunca devidamente creditada ao violonista. Várias de suas composições - como Graúna, Sons de Carrilhões e Interrogando, dentre outras fazem parte ativamente do repertório de chorões e dos violonistas brasileiros, sejam eles populares ou eruditos.

Aluno de Quincas Laranjeira, Donga (1890/1974) frequentava a casa da Tia Ciata ao lado de João da Baiana e Pixinguinha. Com este último, seu irmão, participou do grupo Os Oito Batutas, que fez muito sucesso no Brasil e excursionou pelo exterior em 1922. A sua composição intitulada Pelo Telefone é considerada o primeiro Samba a ser gravado em disco.

Outro membro do grupo Os Oito Batutas e do Grupo Caxangá, China, irmão de Pixinguinha, tocava violão, cantava, tocava piano e banjo. Segundo Pessoa (2012), China é considerado um dos pioneiros do Violão de 7 cordas na música brasileira, tendo introduzido o instrumento em uma gravação em 1910.

O violonista Américo Jacomino (1889/1928), mais conhecido como Canhoto, ficou famoso por seu vibrato peculiar no instrumento. Em 1917, gravou a valsa Acordes do Violão, regravada em 1925 com o título de Abismo de Rosas. Esta tornou-se um clássico do violão brasileiro, executado ainda nos dias atuais.

No entanto, ao entrarmos especificamente na esfera do acompanhamento de Choro ao Violão, o nome de Tute, ou Arthur de Souza Nascimento (1886/1957), ganha relevância. Tute, que também foi contemporâneo de Donga e João da Baiana, é tido como o primeiro dos grandes acompanhadores típicos de Choro, tendo acompanhado o mestre Pixinguinha em suas primeiras gravações. Segundo Cazes (1998, p.49-50), Tute não foi somente um 
instrumentista, ele foi um grande inovador: "Tute foi importante como estilista, como pioneiro e como o introdutor do violão de sete cordas, que lhe dava condição de fazer um acompanhamento mais encorpado e com fraseado mais rico”. Tute, que, além de violão, tocava bumbo na Banda do Corpo de Bombeiros de Anacleto de Medeiros, o que pode lhe ter oferecido proximidade prática com os contrapontos, tem, portanto, papel central na evolução do Violão no Choro. Ao adicionar a sétima corda no Violão, Tute apontou para uma marcante característica do Violão de Choro: os contrapontos na região grave, ou popularmente, as “baixarias”. Segundo Pessoa (2012, p.60):

Tute, ao lado de China, é considerado pioneiro do violão de 7 cordas na música brasileira. China (...) já aparece na iconografia utilizando um violão de 7 cordas desde 1910. No entanto, nota-se nas gravações de Tute maior semelhança com as ideias rítmicas e melódicas propostas por Irineu Batista. (...) Nas décadas seguintes, vão se desenvolver esses modos de tocar e, a partir da união dos dois violões com as inovações técnicas e estilísticas de Tute, será construído um novo modelo dentro dos conjuntos Regionais nas rádios.

Esse período, portanto, marca o nascimento do V7 na música brasileira, instrumento com o qual o V6 viria a desenvolver grandes diálogos musicais.

\subsubsection{Os violões em diálogo}

Pessoa (2012) sugere a distinção de 3 grandes períodos relacionados a transformações da performance de duos de Violão no Regional de Choro, observáveis atualmente graças ao advento da gravação, ocorrido em $1897^{9}$. Ele delimita tais períodos a partir: 1) da prática dos grupos de Choro, de 1907 a 1915; 2) dos Regionais na Era do Rádio e 3) do Conjunto Época de Ouro, na década de 60 do século XX. O terceiro período é marcado pela atuação de Jacob do Bandolim e do Conjunto Época de Ouro, o que parece ter deixado marcas mais profundas na atuação dos regionais subsequentes:

Nas rodas de todo Brasil, ao se tocar Brejeiro, Ingênuo, Lamentos, por exemplo, pode-se observar que se toca o arranjo de Jacob. Tais gravações, que originaram os discos Chorinhos e Chorões, Primas e Bordões e o famoso Vibrações, consolidam uma performance do choro considerada como tradicional. (PESSOA, 2012, p.13)

\footnotetext{
${ }^{9} \mathrm{O}$ fonógrafo foi criado por Thomas Edison em 1877, chegando ao Brasil em 189, através de Frederico Figner. Em 1897 é realizada a primeira gravação de música popular brasileira (PESSOA, 2012). No início do período das gravações se deu preferência às bandas militares, pois sua potência sonora era mais compatível com a tecnologia dos processos de gravação da época.
} 
Ou ainda:

(...) os discos Chorinhos e Chorões, Primas e Bordões e Vibrações apresentam um modelo de acompanhamento que hoje é usualmente tocado em rodas e discos de choro. Esse caráter de tradição moderna do choro associado a esses discos se dá tanto por aspectos estéticos como por questões identitárias relacionadas ao próprio Jacob e sua personalidade. (PESSOA, 2012, p.19).

Portanto, após a consolidação dos regionais, ocorrida no esplendor da Era Radiofônica, passou-se à fase de refinamento musical das formações de Choro, impulsionada pelo trabalho do conjunto Época de Ouro. Tal formação musical alcançou nível técnico muito elevado, quando se imaginou uma preparação camerística para as performances - liderada pelo músico Jacob do Bandolim ${ }^{10}$ - e quando Dino 7 Cordas consagrou a utilização da sétima corda. Esta consagração apontou para uma “escola” específica do instrumento.

Portanto, por volta da década de 1960, o V6 passou a atuar mais frequentemente em complementaridade com o violão de $7 \operatorname{Cordas}^{11}$, embora naturalmente já houvesse a prática complementar entre violões de 6 cordas anteriormente. Foi principalmente nesta performance em dupla que o V6 assumiu complexas funções e formatou diversos idiomatismos. É principalmente nesse tipo de performance que a presente pesquisa irá se ocupar nos capítulos seguintes, pois o trabalho complementar levou os violonistas a desenvolverem inúmeras especificidades na performance.

No Época de Ouro, especificamente, Dino 7 cordas teve como parceiros de violão, na maior parte do tempo, os violonistas Carlinhos Leite e César Faria, ambos muito festejados no mundo do Choro. Nesta complementaridade "violonística”, os violões assumem papéis específicos, embora, naturalmente, complementares. Podemos observar que o V7 cordas tem

\footnotetext{
${ }^{10}$ Além do desenvolvimento musical natural, contribuiu para essa evolução dos regionais a personalidade forte do líder do grupo, o excelente músico e compositor Jacob do Bandolim. Em sua pesquisa sobre a vida do bandolinista, a escritora Ermelinda Paz (1997) revela algumas de suas cartas escritas ao grupo, nas quais fica evidenciado o seu nível de exigência com os músicos do Época de Ouro. Segue abaixo um trecho de uma carta de Jacob do Bandolim (apud Paz, 1997.) aos músicos do Época de Ouro, onde fica evidente, dentre outras coisas, seu esmero pela qualidade da execução: “Aos meus amigos do Conjunto Época de Ouro: (...) Estamos trabalhando, atualmente, como profissionais e com todo o peso da responsabilidade (...). Mas temos perfeita consciência que não estamos tocando com perfeição (...). O que aconteceu sexta-feira no Zum-Zum é inadmissível (...). Pandeiro sobra nas paradas, violões erram, cavaquinho fica tonto e eu, também, acabo me perturbando (...). Mas ninguém estuda. Ninguém treina apenas os 6 números! A isto se resume o Época de Ouro. Que já está virando Ourina... Creiam, sinceramente. A continuar assim, prefiro dissolver o Conjunto, reorganizar outro onde eu encontre a mesma paixão pela música bem apresentada (...). Com a sincera estima e admiração do velho malcriado, Jacob do Bandolim".

${ }^{11}$ Dino 7 Cordas passou a usar o V7 a partir de 1952, e até então tocava apenas o V6 profissionalmente.
} 
uma maior relevância na realização das “Baixarias”, ou seja, os contrapontos na região grave. Muitos músicos reconhecem a inspiração para trabalhar o instrumento dessa maneira a partir dos contrapontos realizados por Pixinguinha ${ }^{12}$ no sax, a exemplo do que faziam o bombardino, o trombone e o oficleide anteriormente. Portanto, o violonista de 7 cordas precisa realizar os contrapontos, frequentemente de improviso, observando a melodia e a harmonia, além de realizar os contrapontos já outrora pré-determinados pelo compositor ou pelo arranjo, os chamados “baixos de obrigação”.

O V6 tem uma maior relevância na realização harmônica e na realização rítmica, embora também realize Baixarias. Trabalhando os acordes numa região média, entre o 7 cordas e o cavaco, o V6 unifica as frequências do espectro entre o agudo do Cavaco e o grave do V7 e “dá liga” ao regional. Quanto à questão rítmica, ele se aproxima do Cavaco e do Pandeiro executando as "levadas” específicas, realizadas pela mão direita. Naturalmente, a flexibilidade musical dos chorões é bastante acentuada, de modo que os papéis podem ser relativizados em situações musicais específicas.

Dentro da perspectiva de trabalhar em complementaridade, gostaría de enumerar alguns importantes violonistas que contribuíram para o desenvolvimento destes "diálogos violonísticos”. Mesmo sob o inevitável risco de não conseguir elencar todos os grandes violonistas de Choro, procurei contextualizar os principais regionais a que alguns destes violonistas pertenceram e algumas de suas contribuições.

Jayme Florence (1909/1982), também conhecido como Meira, foi um dos mais influentes violonistas do gênero, tendo participado do Regional de Benedito Lacerda e do Regional do Canhoto. Além disso, exerceu intensamente a docência, tendo tido como alunos violonistas como Baden Powell, Raphael Rabello, Maurício Carrilho e Paulão 7 Cordas, dentre outros. Segundo o violonista Cidinho 7 Cordas, que também foi aluno do Meira, o apelido surgiu da seguinte forma: “o Meira se chamava Jayme Florence e a razão do apelido é que o pai dele chamava ele de Jaimeira, mas os irmãos dele não sabiam falar direito e aí ficou Meira, mais fácil de pronunciar”. (CIDINHO 7 CORDAS, 2015, E., p.10). Meira lançou algumas composições, tendo o seu Samba-Canção Molambo alcançado notável repercussão.

12 Pixinguinha, considerado por muitos o maior chorão de todos os tempos, por sua vez, teve como professor, em sua infância, o músico Irineu Almeida que tocava trombone, oficleide e bombardino, instrumentos frequentemente afeitos a funções contrapontísticas no Choro. 
Fig: Jayme Florence, o Meira.

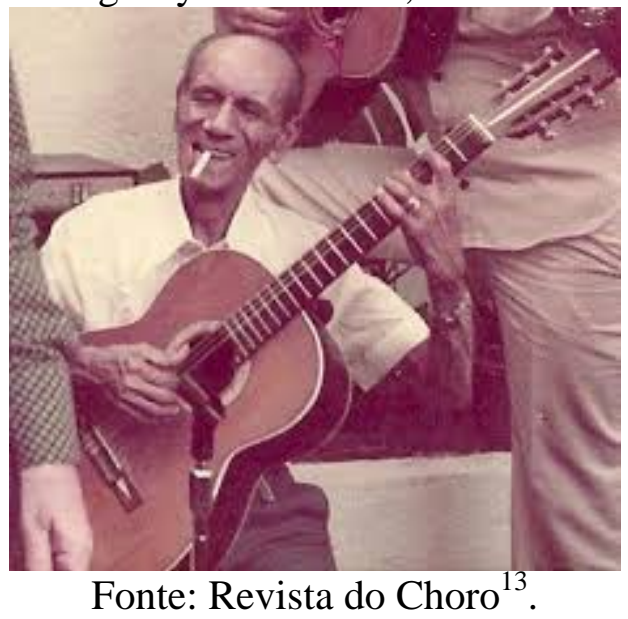

O violonista César Faria (1919/2007), outra grande referência no instrumento, tocou por 30 anos com Jacob do Bandolim, com quem fundou na década de 1960 o Conjunto Época de Ouro.

Fig: César Faria e seu filho Paulinho da Viola.

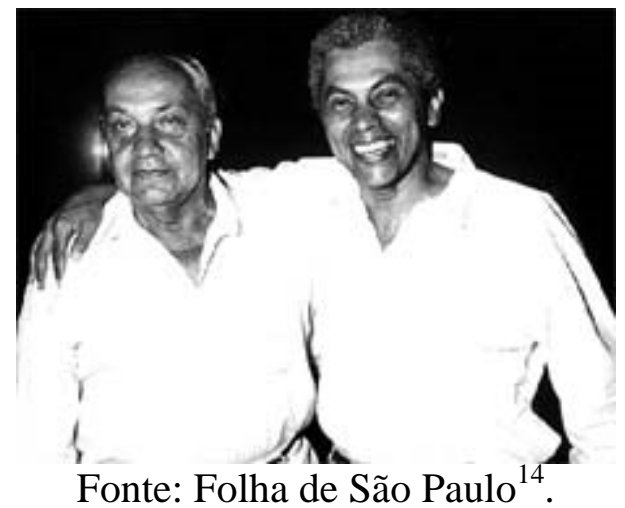

César seguiu com o regional mesmo após a morte de Jacob, com Déo Rian e posteriormente Ronaldo do Bandolim como solistas. Para Paulinho da Viola, com quem atuou por muitos anos, César Faria: “era um dos últimos remanescentes da arte do violão de acompanhamento" (DICIONARIO CRAVO ALBIN DA MÚSICA POPULAR BRASILEIRA, 2016). Além de atuar por muito tempo com Dino 7 Cordas, César também desenvolveu grande parceira com Carlinhos Leite (1924/2010) no mesmo Conjunto Época

13 REVISTA DO CHORO. Jayme Florence, Meira. Arquivo de Cidinho 7 Cordas. Disponível em: $<$ https://blogdarevistadochoro.wordpress.com/2014/10/02/jayme-florence-o-meira-e-lembrado-pela-revista-dochoro-no-dia-de-seu-aniversario-de-105-anos>. Acesso em abril de 2016.

${ }^{14}$ FOLHA DE SÃO PAULO. Morre aos 88 o violonista César Faria, pai de Paulinho da Viola. 21 de outubro de 2007. Disponível em: <http://www1.folha.uol.com.br/ilustrada/2007/10/338527-morre-aos-88-anos-0violonista-cesar-de-faria-pai-de-paulinho-da-viola.shtml?mobile> . Acesso em abril de 2016. 


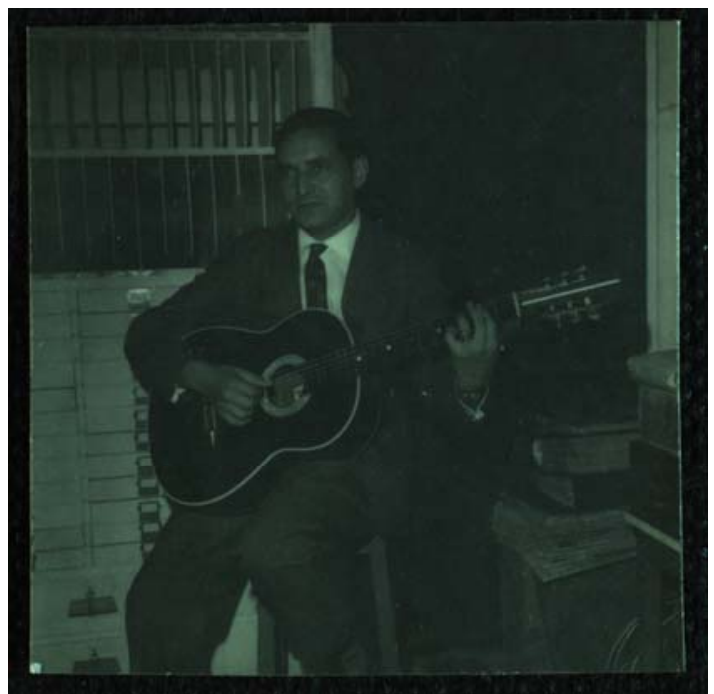

Fonte: Instituto Jacob do Bandolim ${ }^{16}$.

O violonista Carlos Lentine atuou em parceria com o também violonista Nei Orestes no regional de Benedito Lacerda. Segundo Pellegrini (2005, p.36): “no Conjunto Regional de Benedito Lacerda a formação era: Benedito Lacerda na flauta, Canhoto no cavaquinho, Russo no pandeiro, Gorgulho (que mais tarde seria substituído por Carlos Lentine) e Nei Orestes nos violões”. Neste momento, portanto, o regional de Benedito contava com dois violões de 6 cordas, e nenhum violão de 7 cordas. Segundo Lima (2011, p.16) “é importante lembrar Carlos Lentine e Nei Orestes, violonistas que participaram do regional de Benedito Lacerda. Eles foram muito importantes para o desenvolvimento das técnicas de acompanhamento nos regionais”. No entanto, a dupla de violonistas mais tarde (1937) seria substituída por Dino e Meira. Em sua formação ainda mais embrionária, o regional de Benedito Lacerda se chamava Gente do Morro, e contava com Gorgulho e Henrique Brito nos violões. (BITTAR, 2011).

O violonista Jorge Santos se notabilizou no regional de Waldir Azevedo, onde fez dupla com Franscisco Sá. Este é também um caso de dupla de violonistas de 6 cordas. Jorge Santos tocou ainda no regional de Noca do acordeon. Em depoimento para a pesquisa, o violonista e produtor Cláudio Jorge (2016, p.25) relembra seu contato com o violão de Jorge Santos:

Me lembro com clareza de como eu ficava fascinado, por volta dos meus dez anos, vendo o Jorge Santos tocar. Ele fazia o que a gente costuma chamar de "violão de 13", que é aquele V6 de acompanhamento que pontua a harmonia como se fosse um violão de 7. Ele foi a pessoa que me atraiu para aprender o

16 JACOB DO BANDOLIM, InSTITUTO. Damásio Batista. Rio de Janeiro: IJB, 2016. Disponível em:

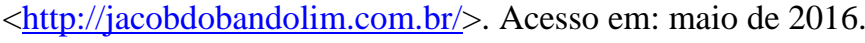


instrumento, especificamente na área de acompanhamento no seis cordas, o chamado violão base, ou de centro. (...) Era um músico antenado, que usava na execução do choro e do samba acordes que só se tornaram corriqueiros quando aconteceu a Bossa Nova.

O sobrinho de Jorge Santos, o Bola Sete, também iria se destacar como grande representante do violão brasileiro.

Em relação ao regional de Waldir Azevedo, nos últimos discos a dupla de violonistas esteve composta por Carlinhos 7 Cordas e Hamilton Costa, músicos residentes em Brasília e de grande importância na consolidação do Choro na nova capital.

Djalma de Andrade (1923/1987), mais conhecido como Bola Sete, começou a tocar cavaquinho aos 3 anos de idade e desde os 17 anos já participava das rodas de Choro da praça Tiradentes. Bola Sete era sobrinho do violonista Jorge Santos, citado acima, e segundo o violonista Luiz Felipe Lima (2011, p.11), Bola Sete “foi sem dúvida um dos grandes violonistas de 6 cordas, não só como acompanhador mas como solista também”. Bola Sete trabalhou na Rádio Transmissora e se destacou por importante carreira internacional, sobretudo nos Estados Unidos, onde chegou a integrar o conjunto de Dizzy Gillespie. Formou parceria com Garoto no grupo Vero e seu Conjunto.

Figura 4 - Bola Sete.

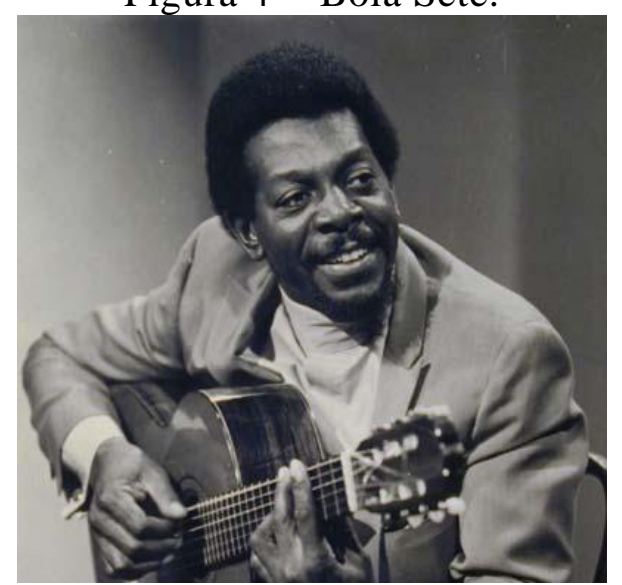

Fonte: Acervo digital do Violão Brasileiro, 2016.

Cidinho 7 Cordas viveu a fase áurea do Choro e, de fato, ajudou a construí-la. Estudou Violão com Meira e Harmonia com Orlando Silveira, e tocou ao lado de grandes expoentes do Choro, até mesmo do mestre Pixinguinha. Constituiu dupla de violão com Arlindo Cachimbo, no Regional do Niquinho e com Voltaire, em algumas participações no 
Regional de Altamiro Carrilho. Além de esmerado violonista, Cidinho é um grande compositor de Choros, tendo lançado um disco autoral em 2012.

O músico Valério de Souza, além de violonista, é multi-instrumentista e exerceu importante papel na consolidação do Choro na capital federal. Nas décadas de 70 e 80 formou dupla violonística com o músico Alencar 7 Cordas (quando gravaram o disco Chorando Callado) e fez parte do Regional de Pernambuco do Pandeiro, tocando ao lado dos maiores nomes do Choro, como Carlos Poyares, Avena de Castro e Raphael Rabello, dentre muitos outros. Atualmente, além de músico, é luthier em Maceió, onde reside.

Nascido em 1970, André Bellieny aprendeu violão com o irmão, e atualmente faz parte do mais longevo e atuante regional de todos os tempos: o Conjunto Época de Ouro, onde faz dupla de violão com Toni 7 Cordas.

Nascido em Salvador, Augusto Contreiras começou a tocar através da influência do pai, Carlos Contreiras. Continuou sua formação de forma autodidata, ouvindo os discos e ouvindo conselhos de violonistas de Brasília, como Alencar 7 Cordas e Carlinhos 7 Cordas. Tem como referências no instrumento no Choro os violonistas Carlinhos Leite e Damásio Batista. Formou duplas de violão com Alencar 7 Cordas e Fernando César.

Fernando César nasceu no Rio de Janeiro, mas fez carreira em Brasília, onde formou duplas violonísticas com José Américo, Alencar 7 Cordas, Everaldo Pinheiro, Augusto Contreiras, Rogério Caetano e Lucas de Campos. Além da carreira brilhante como músico, em que atua com excelência em diversos projetos ligados à divulgação do Choro, possui papel de destaque na formação de novos músicos em Brasília.

O músico José Américo, acima citado, é pai de Fernando César. Filho de músico de banda e nascido em Moreno (PE) em 3 julho de 1935, José Américo de Oliveira Mendes chegou em Brasília em 1977 e desde então é um importante agente de disseminação do Choro na capital federal. Entre seus trabalhos profissionais mais importantes, destaca-se o seu projeto Dois de Ouro, com seus filhos Fernando César e Hamilton de Holanda.

Rafael dos Anjos é um dos maiores representantes da nova geração do violão brasileiro. Após destacar-se em Brasília (onde estudou com os professores Everaldo Pinheiro e Alencar 7 Cordas), sobretudo nos grupos Choro Livre e Firme e Forte, mudou-se para o Rio de Janeiro, onde atualmente trabalha com Hamilton de Holanda e Arlindo Cruz.

Zé Paulo Becker é violonista extremamente atuante no cenário de música brasileira, sobretudo no Rio de Janeiro. Destacam-se os discos gravados com o trio Madeira Brasil e os projetos desenvolvidos com Ney Matogrosso e Roberta Sá. Realizou pioneira pesquisa sobre 
o Violão de 6 Cordas na perspectiva do Conjunto Época de Ouro (1996), e ainda lançou o livro Levadas Brasileiras para Violão (2013). Tais publicações foram frequentemente utilizadas nesta pesquisa. 


\section{COMPETÊNCIAS, HABILIDADES E SABERES}

Procurei descrever a performance do V6 no Choro a partir das principais habilidades musicais envolvidas nesta prática instrumental. No entanto, a palavra "habilidade” possui difusos e amplos significados, muitas vezes associados aos conceitos de saberes, conhecimentos e, principalmente, competências. Garcia (2015), por exemplo, não faz clara distinção entre habilidades e competências, ao sugerir que o desenvolvimento das mesmas possa visto como um dos objetivos de ensino, em uma alternativa à abordagem conteudista. Segundo a autora:

Ao direcionar o foco do processo de ensino e aprendizagem para o desenvolvimento de habilidades e competências, devemos ressaltar que essas necessitam ser vistas, em si, como objetivos de ensino. (...). Caso contrário, o foco tenderá a permanecer no conteúdo (...).

O termo “competência”, por sua vez, foi amplamente utilizado no meio jurídico e ganhou evidência no mundo corporativo. Atualmente, tem sido usado também na área da Educação, como referência para currículos, programa de ensino e formação de professores. Perrenoud (1999, p.30) relaciona competência com a atuação do professor, capaz de mobilizar recursos para enfrentar situações-problema de sua prática docente: “A noção de competência designará uma capacidade de mobilizar diversos recursos cognitivos para enfrentar um tipo de situações”. Le Bortef (1994, p.30) destaca a importância da ação, imputando à competência a necessidade do "fazer" a partir do conhecimento:

Possuir conhecimentos ou capacidades não significa ser competente. (...) Todos os dias, a experiência mostra que pessoas que possuem conhecimentos ou capacidades não sabem mobilizá-los de modo pertinente e no momento oportuno, (...). A atualização daquilo que se sabe em um contexto singular (...) é reveladora da "passagem" à competência. Esta realiza-se na ação.

Marinho-Araújo e Rabelo (2015, p.448) ampliam esse conceito, ao incluir os fatores afetivos e culturais no processo de ensino-aprendizagem, além dos aspectos cognitivos:

Compreender a noção de competência em uma dimensão ampla, contemplando não só aspectos racionais, cognitivos ou mentais, mas também processos intersubjetivos, afetivos, socioculturais... torna-se premente em um cenário no qual as subjetividades perpassam processos educativos e por eles são transformados. 
Tal visão é compartilhada por Burnier e Deluiz (2001), ao destacarem que atualmente a noção de competência já não se dissocia de outras dimensões, como a cognitiva, a emocional, a pessoal e a interpessoal.

Especificamente em relação às competências musicais, Abel Silva (2008, p.3) as descreve da seguinte maneira, apropriando-se das ideias centrais de Perrenoud: “(...) poderíamos então definir as competências (...) como a capacidade de mobilização de conhecimentos, habilidades, atitudes e comportamentos adequados para a realização dos processos envolvidos na preparação e na geração da performance”.

Assumirei esta noção de competência musical no presente trabalho, reconhecendo-a, portanto, como a capacidade de acessar recursos a favor da performance musical. Dentre estes recursos, encontram-se conhecimentos, habilidades, atitudes e comportamentos envolvidos na performance, dentre outros. As habilidades musicais são, portanto, um dos aspectos a serem mobilizados pela competência. Para Perrenoud (1999), uma competência manipula um grupo de esquemas. A concepção de Elliot acerca do conhecimento musical também se aproxima da noção de habilidade musical que pretendo utilizar. Segundo Santos (2007, p.14):

Elliot (1995) compreende conhecimento musical no sentido de saber fazer algo habilmente de maneira a incluir julgamentos normativos em relação a padrões, tradições e éticas de um certo domínio, e também conhecimentos no sentido de compreender princípios e disponibilizá-los em situações contextualizadas.

Podemos encontrar importantes pontos de contato com essa perspectiva na concepção de Swanwick (1994) a respeito do conhecimento musical. O autor aponta para a existência de quatro tipos de conhecimento musical: proposicional ou factual (saber que); o conhecimento pelo fazer (saber como); o conhecimento por familiaridade; e o conhecimento atitudinal. Dentre estas formas de conhecimento apontadas, gostaria de destacar as duas primeiras. Segundo Santos (2007, p. 19):

O conhecimento proposicional corresponde ao "saber que" e compreende definições, fatos, conceitos e descrições sobre música. Para Swanwick (1994) esta possibilidade de conhecimento necessita estar sempre em conexão com a experiência musical, embora não a substitua. (...) Uma segunda camada de conhecimento constitui-se no saber como, (...). Trata-se de um conhecimento que não pode ser adquirido verbalmente, mas somente através do fazer, estando associado a habilidades aurais, manipulativas e notacionais. 
Estas formas de conhecimento musical guardam, em certa medida, algumas semelhanças com os conceitos de habilidade musical e competência musical que pretendo utilizar. As habilidades musicais se relacionam com o conhecimento proposicional uma vez que estão no campo do conhecimento preparatório, e por si só não constituem atividade musical real. As competências, por sua vez, se relacionam com o conhecimento do saber como, onde a atividade prática imprime ao processo outras características, com a possibilidade de absorção de recursos não-verbais. Nesse cenário, gostaria de destacar a Roda de Choro como ferramenta essencial, pois é nela que o instrumentista irá de fato se enriquecer de recursos técnicos, afetivos, socioculturais, dentre outros, e onde aprenderá a lidar com situações novas.

Acredito, portanto, que é na Roda de Choro que o instrumentista colocará em prática as habilidades musicais descritas, e, provavelmente neste contexto, ele irá acessá-las em conjunto com outros recursos, com vistas ao efetivo desenvolvimento da competência musical.

Dentre outras, uma grande contribuição da Roda de Choro a ser assimilada pelo músico é a exposição a novas situações musicais, e o consequente desenvolvimento de geração de respostas adequadas. A perspectiva de relacionar a competência à capacidade de lidar com situações parcialmente imprevisíveis é utilizada por Perrenoud:

(...) uma ação competente é [...] uma 'invenção bem-temperada, uma variação sobre temas parcialmente conhecidos, uma maneira de reinvestir o já vivenciado, o já visto, o já entendido ou já dominado, a fim de enfrentar situações inéditas o bastante para que a mera e simples repetição seja inadequada.” (PERRENOUD apud SILVA, 1999, p. 31)

As entrevistas realizadas com violonistas notáveis de Choro apontaram para a existência de 4 principais habilidades musicais envolvidas com essa performance, a saber: realização da Harmonia; realização de Levadas; realização de Inversões; realização de Baixarias (contrapontos graves típicos do violão). 


\section{METODOLOGIA DA PESQUISA}

O objeto de estudo da pesquisa é o conjunto das habilidades musicais relacionadas à performance de acompanhamento do V6 em um Regional de Choro. A pesquisa tem como objetivo, portanto, investigar as habilidades musicais do V6 como instrumento acompanhador no Choro, identificando e descrevendo tais habilidades.

Para atingir os objetivos propostos, este estudo tem abordagem qualitativa, exploratória e descritiva, que adota técnicas de entrevista e de análise de documentos, partituras e transcrições de gravações.

\subsection{A ENTREVISTA COMO FONTE PRIMÁRIA}

O mapeamento das principais habilidades musicais envolvidas na performance do V6 no Choro foi orientado pelos depoimentos tomados por meio de entrevistas com grandes violonistas de Choro. O conteúdo de tais entrevistas se caracteriza como fontes primárias de conhecimento, uma vez que os entrevistados, de fato, vivenciaram de forma muito intensa o objeto de estudo desta pesquisa. Segundo Alberti (2007, p.16):

Acreditamos que a principal característica do documento de história oral não consiste no ineditismo de alguma informação, nem tampouco no preenchimento de lacunas que se ressentem os arquivos de documentos escritos (...). Sua peculiaridade (...) decorre de toda uma postura com relação à história e as configurações sócio-culturais, que privilegia a recuperação do vivido conforme concebido por quem viveu.

Ao dar voz aos chorões de diferentes gerações, pude ter contato direto com o entendimento individual dos músicos sobre o que definem como habilidades para o V6. Como aponta Montandon (2008, p.1), a entrevista pode constituir-se como importante ferramenta de geração de conhecimento:

Considerando a abordagem interpretativa da pesquisa qualitativa, onde seus pesquisadores estudam as coisas a partir de seus contextos reais, "tentando entender, ou interpretar os fenômenos em termos dos significados que as pessoas a eles conferem" (Denzin e Lincoln, 2003, p. 17), a entrevista pode ser uma ferramenta eficaz no levantamento de dados para a produção de novos conhecimentos a partir do universo pessoal de cada um. 
Apesar de atuar como violonista de Choro há mais de 15 anos, na atitude investigativa procurei me abster ao máximo de minhas certezas pessoais acerca do tema, procurando, efetivamente, aprender com o discurso dos entrevistados. Na perspectiva de Montandon (2008, p.3):

Como observa Garcia (In, Moreira at al, 2001), “quem tem certezas não tem boas razões para fazer pesquisa [...] a dúvida, a incerteza, a insegurança, a consciência de nosso ainda não saber é que nos convida a investigar e, investigando, podermos aprender algo que antes não sabíamos”.

Diante da escassez de métodos e trabalhos especificamente relacionados ao V6, a entrevista com violonistas, conjugada com a transcrição das gravações, se apresentou como a melhor estratégia a ser adotada. A escolha dos entrevistados esteve baseada na importância que estes possuem no universo do Choro e no envolvimento que julgo possuírem com a história e os acontecimentos relacionados a esta matéria. Nas palavras de Verdi:

A escolha dos entrevistados não deve ser predominantemente orientada por critérios quantitativos, por uma preocupação com amostragens, e sim a partir da posição do entrevistado no grupo, do significado de sua experiência. (...) convém selecionar os entrevistados entre aqueles que participaram, viveram, presenciaram ou se inteiraram das ocorrências ou situações ligadas ao tema e que possam fornecer depoimentos significativos. (VERDI, 2007, p.32)

Diante dessa perspectiva, escolhi para as entrevistas músicos decididamente dedicados ao Choro e ao Violão, com carreira notadamente reconhecida na área. Os violonistas entrevistados foram: André Bellieny, Augusto Contreiras, Cidinho 7 Cordas, Fernando César, José Américo, Rafael dos Anjos, Valério de Sousa e Zé Paulo Becker. Além desses violonistas, foi entrevistado o bandolinista Jorge Cardoso, grande conhecedor da complexa engrenagem de um Regional de Choro. O violonista Cláudio Jorge também ofereceu valiosas contribuições, sobretudo a respeito do violonista João Santos.

Todos os músicos concordaram em participar da pesquisa e deixo registrado novamente o respeito e admiração pelos entrevistados, e minha gratidão pelos depoimentos.

A pesquisa contribuirá também, certamente, para a qualificação da minha performance e de outros instrumentistas, na medida em que reforça conhecimentos que eu já possuía e amplia em vários sentidos minha compreensão sobre o próprio instrumento.

Em paralelo à análise das entrevistas, utilizei a análise de transcrições de Choros. Em relação às gravações, Wilkinson, citado por Bittar, aponta serem: 
um imenso "repositório de indícios" sobre uma determinada prática musical, servindo como fonte de dados a pesquisas com os mais diferentes propósitos. Isso porque através da escuta atenta e repetida, as gravações possibilitam a descoberta e consequente análise de elementos que dificilmente seriam identificados durante uma performance ao vivo. Além disso, esse processo de estudo destes registros fonográficos, além de elucidar diversas questões, é extremamente prazeroso. (WILKINSON apud BITTAR, 2009, p.2).

Além das transcrições realizadas diretamente para a pesquisa, utilizei em determinados momentos partituras originais de Ernesto Nazareth e de Chiquinha Gonzaga. Isto porque, grande parte da música tocada pelos chorões contemporâneos não estava escrita e, portanto, as partituras de piano, editadas na época, são importantes registros do estilo composicional e da performance do início do Choro.

\subsection{PROCEDIMENTOS DE ENTREVISTAS}

As entrevistas foram realizadas à distância ou pessoalmente e alguns músicos foram entrevistados pelos dois procedimentos. As entrevistas à distância, por sua vez, foram realizadas de duas diferentes formas:

1) Entrevista estruturada com questões abertas respondidas por e-mail.

2) Conversas, com caráter mais aberto, com roteiro, realizadas pelo Facebook.

Em alguns casos, a entrevista realizada por e-mail foi um momento inicial de interação, apenas um primeiro passo para uma conversa mais detalhada posteriormente in loco.

O roteiro de entrevista procurou atender às seguintes categorias, previamente definidas de acordo com os objetivos da pesquisa: Formação musical; Atuação profissional e no Choro; Influências musicais e parceiros musicais; Função e papel do V6 no Choro; Competências musicais relacionadas ao V6; Repertório significativo.

A partir destas categorias, a entrevista esteve baseada em um roteiro estruturado com as seguintes perguntas:

1) Qual seu nome e local de nascimento?

2) Como aprendeu o Violão 6 cordas e como aprendeu o Violão 6 cordas no Choro?

3) Quais são os seus violonistas de referência de Violão 6 cordas no Choro?

4) Quais são seus principais parceiros musicais?

5) Com que violonistas formou duplas no Choro? 
6) Qual o papel do 6 cordas no Choro? Quais as principais habilidades musicais envolvidas? Poderia escrever um pouco mais detalhadamente sobre elas?

7) Como você percebe o Violão de 6 cordas atualmente no Choro?

8) Em termos de trabalho dos violões, quais são suas 3 gravações de Choro preferidas?

As respostas das perguntas de 1 a 5 auxiliaram a ampliar a biografia dos entrevistados de maneira mais linear. As respostas da pergunta 6 estão relacionadas diretamente com os objetivos da pesquisa em relação às habilidades musicais. As respostas da pergunta 7 serviram para corroborar minha justificativa na problematização da diminuição da utilização do V6, e a pergunta 8 orientou a escolha do repertório analisado. Cabe destacar que, logo nos primeiros contatos, os entrevistados souberam dos objetivos da entrevista e que todos eles permitiram a utilização dos conteúdos na pesquisa.

\subsection{ANÁLISE DAS ENTREVISTAS}

Em seu conjunto, as entrevistas revelaram três principais grupos de informação. Em primeiro lugar, elas levantaram aspectos importantes da formação musical dos entrevistados e de sua trajetória musical.

Em segundo lugar, as entrevistas apontaram para a existência de 4 principais habilidades musicais a serem dominadas pelo violonista de 6 cordas no Choro: Harmonia, Levadas rítmicas, Inversões de acordes e Baixarias. Essas habilidades foram fundamentais para aprofundar o objeto de estudo da pesquisa e para mapear a performance do V6. Cada uma delas será detalhada no próximo capítulo.

Por fim, as respostas dos entrevistados indicaram o repertório de preferência em relação à atuação da dupla V7 e V6. Tal repertório foi utilizado como repertório base para a transcrição e análise das performances, e por meio dele as quatro habilidades musicais, anteriormente citadas, foram identificadas e descritas. O repertório apontado como significativo pelos entrevistados é apresentado no quadro abaixo:

Quadro 1 - Músicos entrevistados e seu repertório básico de referência com indicação do intérprete entre parênteses:

\begin{tabular}{|c|c|}
\hline MÚSICOS & REPERTÓRIO DE \\
ENTREVISTADOS & PREFERÊNCIA/INTÉRPRETE \\
\hline ANDRÉ BELLIENY & $\begin{array}{c}\text { Falta-me Você (Jacob do Bandolim) } \\
\text { Vibrações (Jacob do Bandolim) }\end{array}$ \\
\hline
\end{tabular}




\begin{tabular}{|c|c|}
\hline & Evocação (Altamiro Carrilho) \\
\hline AUGUSTO CONTREIRAS & $\begin{array}{c}\text { Arabiando (Choro Livre) } \\
\text { Chorinho na Praia (Déo Rian) } \\
\text { Vibrações (Jacob do Bandolim). }\end{array}$ \\
\hline CIDINHO 7 CORDAS & $\begin{array}{c}\text { Sofres por que queres (Jacob do Bandolim) } \\
\text { Cuidado Violão (Altamiro Carrilho) } \\
\text { Ainda me recordo (Altamiro Carrilho) }\end{array}$ \\
\hline FERNANDO CÉSAR & $\begin{array}{c}\text { Chorinho na Praia (Déo Rian) } \\
\text { Vibrações (Jacob do Bandolim) } \\
\text { Ternura (Tiago Tunes) }\end{array}$ \\
\hline JORGE CARDOSO & $\begin{array}{c}\text { Ingênuo (Jacob do Bandolim) } \\
\text { Harmonia Selvagem (Altamiro Carrilho) }\end{array}$ \\
\hline JOSÉ AMÉRICO & Muíte Retratos (Jacob e Radamés Gnatalli) \\
\hline Mibrações (Jacob do Bandolim) \\
Minha gente (Jacob do Bandolim) \\
Floreaux (Jacob do Bandolim)
\end{tabular}

Fonte: Dados do autor.

Por serem os mais citados, os choros Vibrações e Chorinho na Praia foram prontamente transcritos. Nenhum outro Choro, além desses, apareceu de forma destacada. Diante desse quadro, tomei a liberdade de escolher alguns deles para serem transcritos, como Cuidado Violão, Arabiando, Sofres porque queres e Harmonia Selvagem. Por apresentarem intensa participação dos violões e por considerar importantes para a caracterização de paradigmas de comportamento idiomático, também foram transcritos os Choros Naquele tempo, Enigmático e Seu Lourenço no vinho, embora não tenham sido citados diretamente nas entrevistas.

\subsection{SOBRE AS TRANSCRIÇÕES E AS ANÁLISES DO REPERTÓRIO}

Em seu livro A afinação do mundo, Schafer declara que a notação musical representa "uma tentativa de substituir fatos auditivos por sinais visuais.” (SCHAFER, 1997, p. 175). 
Esta tentativa jamais é integralmente bem-sucedida, e, portanto, a notação musical por si só apresenta limitações estruturais.

Em alguns gêneros de música popular, determinado conjunto de conhecimentos musicais relativos à performance é compartilhado pelos músicos daquele ambiente, de forma que a notação não se ocupa com determinados aspectos tacitamente acordados entre aqueles indivíduos “através da observação direta e da tradição oral” (ARAGÃO, 2013, p. 164). Segundo Sève:

O jazz, o choro e outros estilos e gêneros populares costumam ter também suas músicas notadas apenas com indicações essenciais - ritmos melódicos, formas, alturas, tonalidades e sugestões de andamento (...). Detalhes de articulação, de dinâmicas e agógicas (...) raramente são prescritos. Muitos procedimentos interpretativos encontram-se revelados em um sistema de códigos compartilhados pela tradição oral. (SÈVE, 2016, p.1305).

O exemplo do violonista e pesquisador Luiz Otávio Braga (2002, P. 31) ilustra certa “divergência” entre a notação e a realização musical.

As semínimas, nas linhas de baixo, são tocadas com maior frequência com um pouco de efeito staccato. Suas durações, portanto, não são integrais e estariam no limite da colcheia. Nesse caso, a própria mão esquerda "corta” a duração indicada na partitura, com a retirada sutil da pressão da mão. Da mesma forma, semínimas indicadas com pizzicato são interpretadas como colcheias, ao que os violonistas chamam de "efeito tuba". A rigor, não se indica na partitura o que fazer, estando a oportunidade de uma ou outra ação a critério do violonista.

Segundo Remo Pellegrini (2005, P. 45), a constituição acústica dos instrumentos normalmente auxilia esse recurso de performance:

Pela estrutura de construção do instrumento, a ressonância de cada nota é bem mais curta que em violões de concertista, o que leva esse instrumento a uma característica quase percussiva. Essa é uma preferência dos violonistas tradicionais para que a sonoridade de seus instrumentos não se sobreponha à melodia principal, expondo sua função harmônico/melódica e se fundindo ao naipe de percussão.

Portanto, as semínimas indicadas nas transcrições não duram exatamente o valor de uma semínima, assim como em alguns casos a colcheia não dura o valor completo de uma colcheia. Sob essa perspectiva, as transcrições apresentadas nesta pesquisa foram realizadas 
com a consciência de que apenas o envolvimento real com o gênero musical é capaz de impulsionar a internalização de determinados recursos idiomáticos, como o acima citado.

A respeito das transcrições, é necessário destacar ainda a dificuldade encontrada em realizá-las na perspectiva da audição, uma vez que os antigos sistemas de gravação não possuíam uma captação individualizada dos instrumentos, o que implica na dificuldade de percebê-los e identifica-los. Grande parte das transcrições foi realizada a partir de gravações cuja captação foi executada com uma pequena quantidade de canais, como observado na equalização do disco Vibrações (realizada pelo técnico Darci da RCA Victor em 20/06/1967 e fixada no interior do estojo de Jacob do Bandolim), em que é possível confirmar que diferentes instrumentos “dividiam” alguns canais, o que gera dificuldades na mixagem individual de cada um deles.

Figura 5 - Equalização do disco Vibrações.

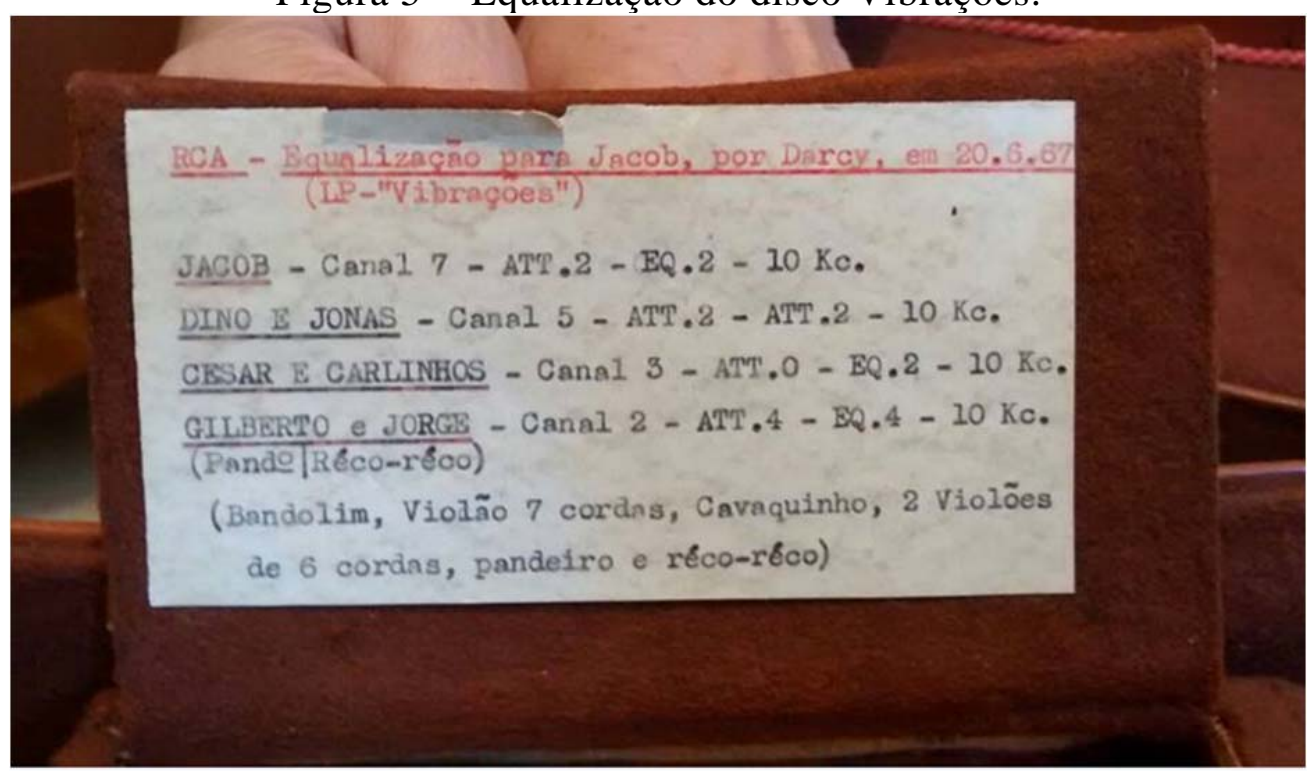

Fonte: Acervo Jorge Cardoso ${ }^{17}$.

Tal dificuldade é agravada pelo fato do V6 estar posicionado em uma situação intermediária no espectro de frequências do conjunto, o que prejudica a audição da sua performance. Nesse tipo de gravação, os “extremos” de frequência (os agudos do solista ou os

${ }^{17}$ CARDOSO, Acervo de Jorge. Equalização para Jacob, por Darcy. LP Vibrações. Rio de Janeiro: RCA - 20 $\begin{array}{llllll}\text { de junho } & \text { de } & 1967 . & 1 & \text { imagem. } & \text { Disponível }\end{array}$ $<$ https://www.facebook.com/photo.php?fbid=10210210999740688\&set=a.10201856036671833.1073741826.15 10515979\&type=3\&theater $>$. Acesso em: 16 de julho de 2016. 
graves do V7) são frequentemente mais perceptíveis do que o V6, tanto pela própria questão de sua posição no espectro, como em função das mixagens e volumes adotados.

O músico e pesquisador Iuri Lana Bittar, que também percebeu tais dificuldades ao transcrever a performance do violonista Meira, aponta que "na grande maioria das gravações notamos o violão de Dino (V7) bem claro, enquanto para se ouvir o violão de Meira (V6), necessitamos de um grande esforço, normalmente com recompensas insatisfatórias”. (BITTAR, 2011, p.98).

Tais dificuldades são ainda agravadas quando o grupo possui 3 violões, ou seja, um V7 e dois V6s, como no Época de Ouro, cuja equalização apresentada na figura acima aponta que os violões de César Faria e Carlinhos Leite compartilham o canal 3.

Portanto, é preciso destacar essas ressalvas em relação às transcrições. Nesta pesquisa, preferi as nomear como transcrições baseadas nas gravações utilizadas, pois em alguns trechos é realmente muito difícil decupar o V6.

Convém também justificar o formato escolhido para as transcrições apresentadas. A partir da constatação das importantes relações entre melodia e V6 e entre V7 e V6, optei por ir além de uma transcrição isolada do V6 e apresentar três linhas na grade transcrita: melodia, V6 e V7, nesta ordem, com a harmonia apresentada entre o V6 e o V7. Este formato me pareceu mais adequado para a visualização e análise das performances transcritas, uma vez que a visão geral das três linhas, simultaneamente expostas, possibilita uma imediata avaliação vertical a cada trecho. Especificamente, em relação à transcrição dos violões, optei por escrever apenas o baixo. A escrita de toda a digitação de cada acorde me pareceu exagerada aos propósitos da pesquisa e, além disso, geraria uma quantidade de informações que acabaria por dificultar a visualização e a análise das competências musicais discutidas. A harmonia - cifra - apresentada entre os violões e os baixos transcritos na segunda e terceira linhas são suficientes para indicar a sua performance. Apesar da cifra ser uma notação imprecisa na perspectiva da disposição do acorde, as principais formações de acordes típicas do Choro (em suas disposições mais tradicionais) são apresentados na secção Harmonia e na secção Inversões, o que irá auxiliar na visualização da formação do acorde sem precisar explicitá-lo integralmente a cada momento. No entanto, em alguns casos especiais, é oferecida, especialmente na transcrição de Levadas, uma transcrição literal dos acordes. Em relação à análise harmônica contida na secção Harmonia, é importante frisar que foram utilizados algarismos romanos simples (I, II, III...) para os acordes pertencentes ao campo 
harmônico correspondente ${ }^{18}$. O acorde dominante foi cifrado como V (apenas), para evitar confusão com a sigla utilizada para o violão 7 cordas - V7.

Por fim, os comportamentos descritos nas análises apresentadas podem ser encarados como apontamentos para uma generalização dos detalhes dessa performance, uma vez que o repertório escolhido é bastante representativo. No entanto, quanto mais transcrições e análises forem feitas, maior será a segurança probabilística em se cravar paradigmas da performance, naturalmente.

${ }^{18}$ Ou seja, o algarismo II, por exemplo, pode representar diferentes tipos de acorde, a depender do contexto do campo harmônico. No contexto de C, II significa Dm, por ser o acorde pertencente ao campo harmônico de C. No contexto de Cm, II significa Dm7(b5), por se tratar do acorde correspondente àquele campos harmônico. 


\section{AS HABILIDADES DO V6 NO CHORO PARA ACOMPANHAMENTO}

Como em qualquer estilo musical, parte importante daquilo que caracteriza o Choro pode ser identificada a partir das relações musicais entre os instrumentos utilizados naquele estilo. Livingston e Garcia (2005, p.3) destacam esta perspectiva: “O estilo Choro é fundamentado nas relações particulares entre os instrumentos do conjunto (...). Os instrumentos preenchem quatro requisitos sonoros básicos: a melodia, o centro, a linha de baixo e a linha rítmica” ${ }^{\text {.19 }}$.

Na publicação em questão, os autores sugerem ainda uma clara definição de papéis. De um modo geral, eles definem que Bandolim e Flauta são responsáveis pela Melodia; Cavaco e V6 são responsáveis pelo Centro; V7 é o responsável pelo baixo; e o Pandeiro é responsável pelo ritmo (LIVINGSTON-ISENHOUR \& GARCIA, 2005, p. 4 a 10).

No entanto, os autores apontam a possibilidade de flexibilização de funções, com instrumentos assumindo papeis que não fazem parte de sua lista primordial de tarefas: “Embora cada instrumento do conjunto de choro esteja associado a um papel funcional, há uma grande flexibilidade e espontaneidade no desempenho real, e os instrumentos muitas vezes podem mudar temporariamente de papéis durante uma peça”20 (LIVINGSTONISENHOUR \& GARCIA, 2005, p.3).

De fato, as funções de instrumento dentro de um regional de Choro são determinadas a partir de uma intensa dinâmica, de modo que se torna muito difícil determinar com precisão que instrumento é responsável por cada função. Proponho, no presente trabalho, o exercício inverso, buscando compreender que funções diversificadas (as quais estão sedo chamadas de Habilidades Musicais) são exercidas pelo V6 na performance de Choro.

É importante observar que, em certa medida, Livingston e Garcia traduzem essa perspectiva. Ao descrever a função de Centro, os autores acabam por flexibilizar a função do V6 e do Cavaco. Vejamos o que eles dizem sobre a função de Centro do Cavaco:

O papel do centro é considerado um elemento-chave por músicos de choro do tradicional. A função do cavaquinho é o Centro, na maioria das formações de choro. O seu papel é fornecer a base rítmica e harmônica com a música que é fundamental para o fluxo básico e textura do choro. O violonista é liberado de ter que fornecer continuamente acordes e

\footnotetext{
${ }^{19}$ Choro style is grounded in the particular relationships among the instruments of the ensemble (...) The instruments fulfill four basic sonic requirements: the melody, the center, the bass line and the rhythmic line.

${ }^{20}$ Although each instrument of the choro ensemble is associated with a functional role, there is a great deal of flexibility and spontaneity in actual performance, and instruments often temporarily swicth roles during a piece.
} 
acompanhamento rítmico, permitindo-lhe se concentrar na criação de uma linha de baixo interessante em seu lugar. (...). Dos cavaquinistas é esperado que improvisem ritmos e apresentem variações nas reexposições $(. . .)^{21}$. (LIVINGSTON; GARCIA, 2005, p.5).

\section{Em seguida, os autores passam à descrição da função de Centro do V6:}

O violão também pode preencher o papel de centro, especialmente em casos em que existam dois ou mais violões no regional. Os acompanhamentos harmônicos do violão são tangidos em blocos de acordes ou arpejados (...). Um acompanhamento típico muitas vezes incorpora a semicolcheia constante do pandeiro com uma forte articulação da batida, normalmente fornecida pelo polegar da mão direita. O violonista tocando um padrão de semicolcheia constante pode ocasionalmente enfatizar que não sejam os tempos fortes para sustentar o interesse notas ${ }^{22}$. (LIVINGSTON; GARCIA, 2005, p.5).

Em relação aos aspectos rítmicos acima citados, os autores afirmam que:

O violão também pode tocar o ritmo do pandeiro combinado com figuras rítmicas afro-brasileiras típicas em qualquer combinação, a critério do músico que, quando se fundiu com a linha de cavaquinho, cria o ritmo semicolcheia característica constante de choro. Estas figuras rítmicas são muitas vezes tocadas com várias técnicas de articulação: silenciar as cordas com o braço direito, produzindo um efeito violino pizzicato; silenciar as cordas com a mão esquerda, criando uma variedade de timbres; incluindo ou omitindo cordas abertas para mudar a sustentar do acorde; e articulação legato da nota mais grave, com a mão esquerda combinada com o cessar dos ataques da mão direita $^{23}$. (LIVINGSTON; GARCIA, 2005, p.6)

\footnotetext{
${ }^{21}$ The role of center is considered a key element by traditional choro musicians. The cavaquinho (...) functions are the center in most choro ensembles. Its role is to provide the rhythmic and harmonic underpinning to the music that is fundamental to the basic flow and texture of choro. The guitarist (sic) is released from having to continuously provide chordal and rythmic accompaniment, allowing him or her to concentrate on creating and interesting bass line instead (...). Players are expected to improvise rhythms, and variation in repeated sections (...).

${ }^{22}$ The guitar may also fill the center role, especially in cases where there are two or more guitars in an ensemble. The harmonic accompaniments of the guitar are plucked in block chords or arpeggiated in a rhythm that tends to be less complex than of the cavaquinho. A typical accompaniment often incorporates the constant sixteenth-note of the pandeiro with a strong articulation of the beat, usually provided by the thumb of the right hand. The guitarrist playing a steady quarter pattern may occasionally emphasize notes other than the downbeats to sustain interest.

${ }^{23}$ The guitar may also play the pandeiro rhythm combined with typical Afro-Brazilian rhythmic figures in any combination at the discretion of the player which, when merged with the cavaquinho line, creates the hallmark constant sixteenth-note rhythm of choro. These rhythmic figures are often played with various articulation techniques: muting the strings with the right arm, producing a violin pizzicato effect; muting the strings with the left hand, creating a variety of timbres; including or omitting open strings to change the sustain of the chord; and legato articulation of the lowest note with the left hand combined with the cessation of plucking with the right.
} 
A esta altura, já podemos notar uma forte aproximação da função de Centro com a função de Ritmo, anteriormente apontada pelos autores, e primordialmente reservada ao pandeiro. Interessante também destacar a riqueza da descrição das possibilidades de articulação do V6 realizada pelos autores.

Na secção seguinte eles passam à função de Baixo. Apesar da predominância idiomática do V7 nesta função, aqui também o V6 aparece como elemento importante: "Uma marca característica do Choro são as elaboradas linhas de baixo tocadas pelo V6 ou pelo V7, normalmente improvisadas ${ }^{24 ”}$ (LIVINGSTON; GARCIA, 2005, p.6)

Portanto, o V6 está intimamente ligado, com exceção da função Melodia (posto que a presente pesquisa não trata do Violão solista, e sim do Violão acompanhador), a todas as outras funções (Centro, Baixo e Ritmo) descritas por Livingston e Garcia (2005). Nesta perspectiva, parece um caminho mais seguro descrever os instrumentos (em particular o V6) em função das Habilidades Musicais - e não o oposto - tomando as inter-relações entre os instrumentos como aspecto essencial a ser observado.

Como descrito anteriormente, tomarei como Competência Musical a capacidade de dispor recursos a favor da performance, e dentre tais recursos estão as Habilidades Musicais. As principais Habilidades Musicais identificadas nos depoimentos realizados com chorões notáveis foram: Harmonia, Levadas, Inversões e Baixarias. Tais Habilidades tem íntima ligação com as funções propostas por Livingston e Garcia (2005), e irei descrevê-las mais apropriadamente nas secções seguintes.

5.1 HARMONIA “Segurando a harmonia junto com o cavaquinho”25

A frase acima, proferida pelo violonista Augusto Contreiras em depoimento para esta pesquisa, descreve sinteticamente uma Habilidade Musical do V6 em um regional de Choro: a realização das Harmonias. Dentro desta habilidade, muitas questões precisam ser observadas no contexto do Choro. Portanto, nesta secção reflito sobre algumas características diretamente relacionadas à Harmonia no Choro, como os Acordes Característicos, a Condução Harmônica e a Perspicácia Harmônica.

\footnotetext{
${ }^{24}$ A hallmark feature of choro style is an elaborated, usually improvised, bass line played on the lower strings of the six- or seven-string guitar.

${ }^{25}$ CONTREIRAS, 2015, Entrevista, p.6.
} 


\subsubsection{Acordes Característicos}

A partir dos depoimentos nas entrevistas, da análise das transcrições e da minha própria experiência com o estilo, pude notar que o Choro, assim como outros estilos musicais, demonstra preferências em relação a algumas Categorias de acordes e a algumas Formações específicas de acordes.

Em relação às Categorias de acordes, se por um lado os chorões utilizam eventualmente tensões nos Acordes Dominantes (sobretudo 9, b9, 13 e b13), eles raramente utilizam os Acordes Maiores com tensões muito pronunciadas, uma vez que a utilização de tais tensões parecem fugir ao estilo. Becker (1996, p.92) discorre sobre essas tensões:

Geralmente nos acompanhamentos de choros tradicionais tensões mais brandas ou os acordes vem mesmo sem nenhuma tensão - o que alguns chorões costumam chamar de "acorde gavetão". Sétima maior e nona, por exemplo, raramente são usadas em acordes de função tônica, a não ser no desfecho da obra. Nos acordes com função de dominante poderá surgir a nona menor ou maior, a décima terceira e em alguns casos a décima primeira aumentada.

É possível observar uma grande quantidade de acordes sem tensões, pois estas ocorrem de maneira muito específica no ambiente de Choro tradicional. Como exemplo apresento um trecho do Choro Seu Lourenço no Vinho de Pixinguinha:

Figura 6 - Acordes sem tensão - trecho de Seu Lourenço no Vinho (Pixinguinha) 

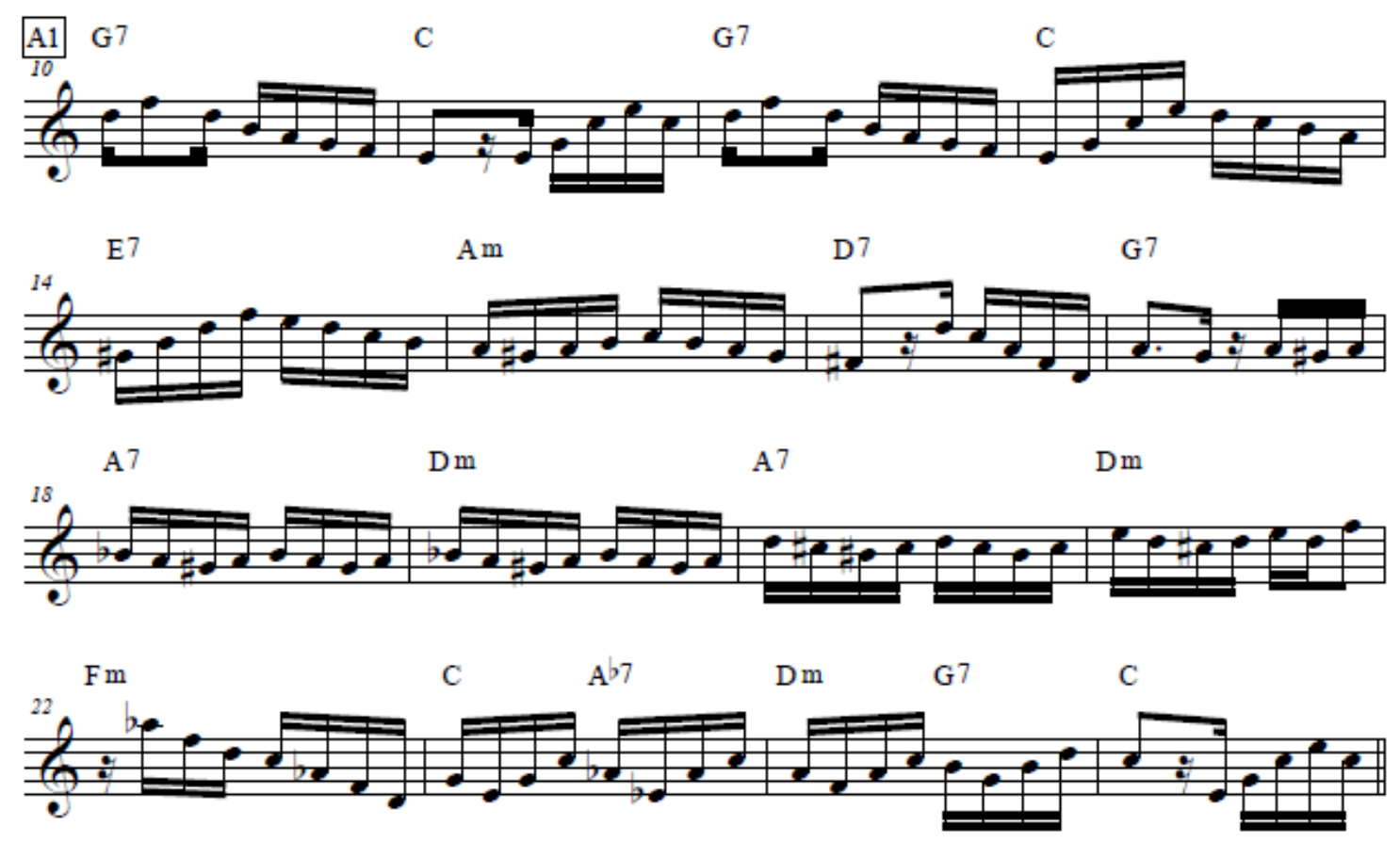

Fonte: transcrição do autor.

Na figura acima, é possível perceber uma grande quantidade de acordes sem tensões adicionadas. Os acordes maiores e menores em função tônica normalmente são utilizados na forma de tríade, sem qualquer tensão. Os acordes dominantes seguem a mesma tendência da ausência de tensões, apresentando-se na maior parte do tempo como tétrades simples. Tensões podem eventualmente aparecer nos acordes dominantes, sobretudo a 9 e a 13 em preparações para acordes maiores, e (b9) e (b13) para preparações de acordes menores. A tensão (b9) em alguns casos aparece no baixo, transformando o acorde dominante em um acorde diminuto, mantendo a função preparatória.

Naturalmente, exceções ocorrem. Nesses casos, provavelmente, a Melodia irá demonstrar a possibilidade de se utilizar as tensões na Harmonia, configurando casos específicos, como em Carioquinhas no Choro ou Migalhas de Amor. Como importante exceção à regra, aponto a utilização do Acorde Menor com a tensão de sexta. Porém, como o acréscimo da sexta se dá mais frequentemente no baixo, o tema é apresentado na secção de Inversões.

Ainda na perspectiva do assunto dos acordes típicos, convém apontar determinadas preferências dos chorões nas formações dos acordes, ou seja, na disposição das notas dos acordes. Apresento a seguir as disposições mais recorrentes dos acordes maiores, menores e dominantes. 
Figura 7 - Acordes maiores - digitações recorrentes no Choro.
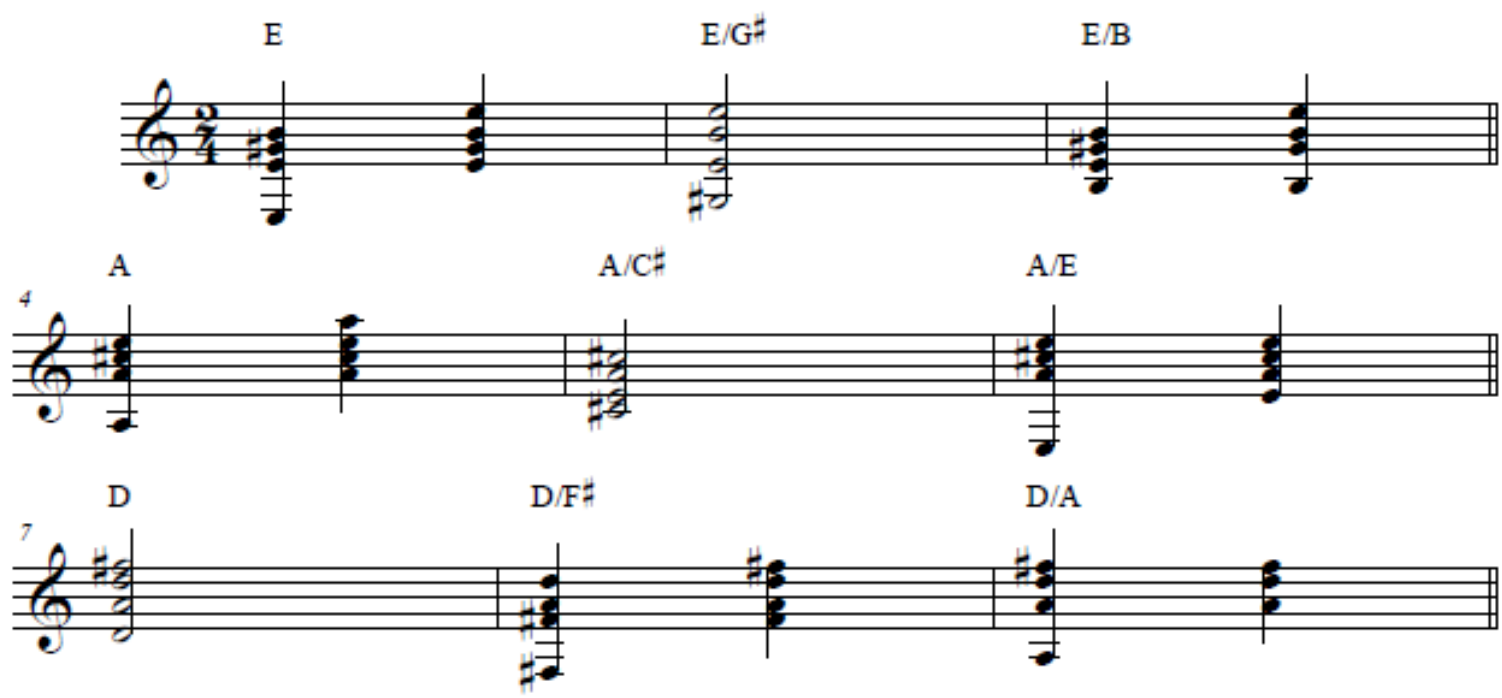

Fonte: transcrição do autor.

Na figura a seguir são apresentadas formações típicas dos acordes menores:

Figura 8 - Acordes menores - digitações recorrentes no Choro
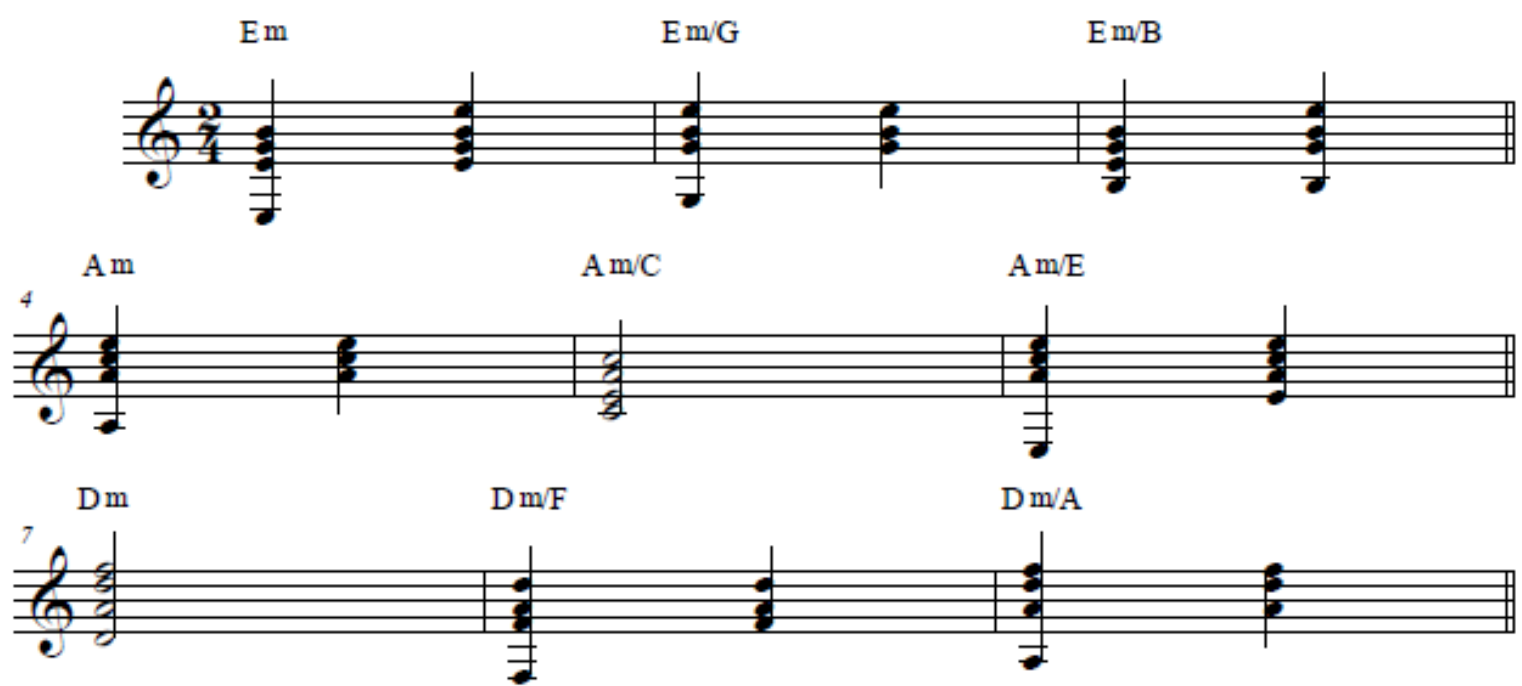

Fonte: transcrição do autor

A respeito dos acordes menores convém destacar uma formação típica que não está facilmente dedutível na figura acima. Trata-se da disposição do acorde de $\mathrm{Cm} / \mathrm{Eb}$, amiúde presente na performance do V6:

Figura 9 - Disposição do acorde Cm/Eb. 


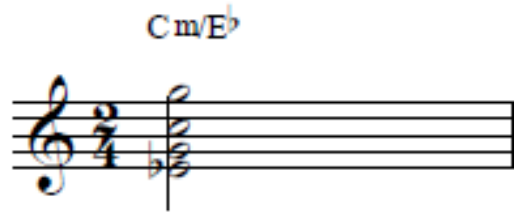

Fonte: Transcrição do autor.

A seguir estão relacionadas típicas formações de acordes dominantes:

Figura 10 - Acordes dominantes - digitações recorrentes no Choro
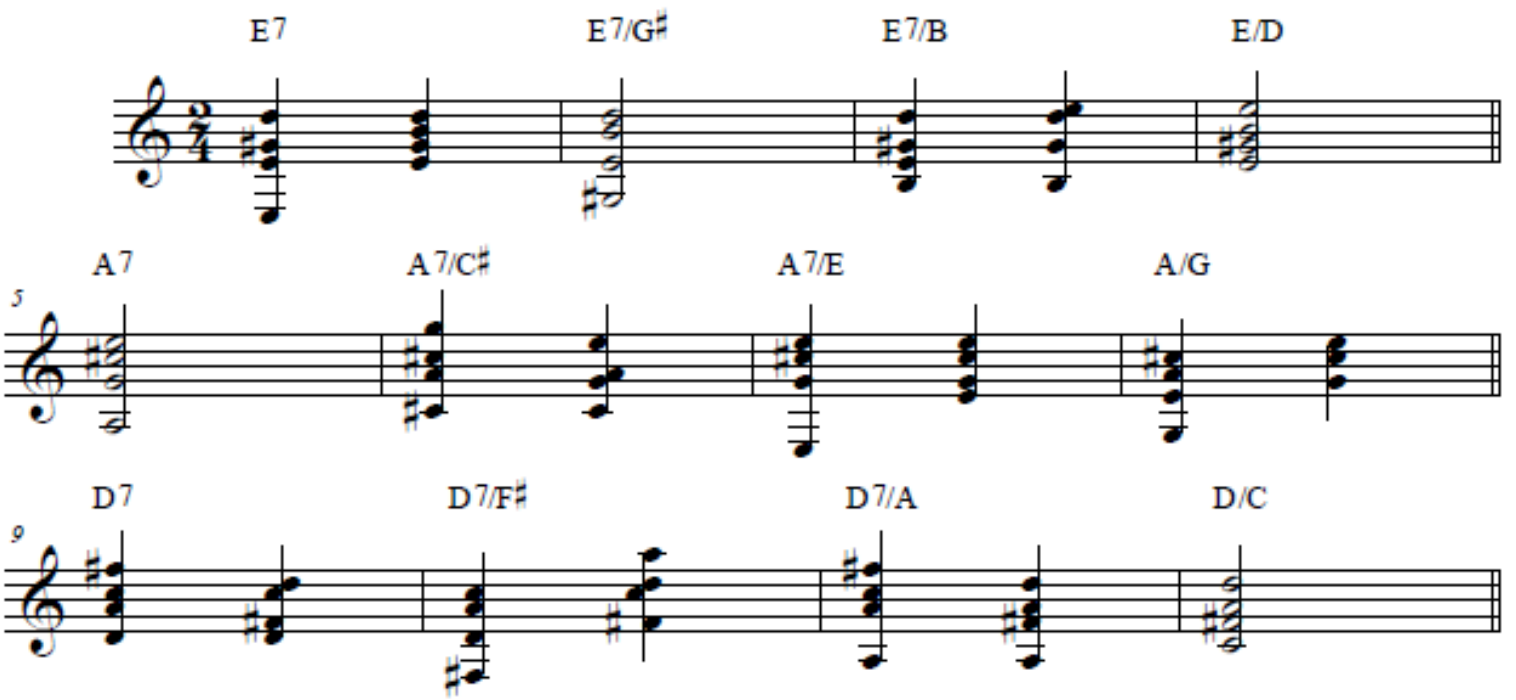

Fonte: transcrição do autor

Na perspectiva apresentada, os tópicos sobre formações de acordes se confundem com o tema Inversão de acordes, como veremos adiante. As disposições de acordes apresentadas aqui servirão de referência para as demais transcrições, posto que estas se prestarão a apontar apenas o baixo dos acordes.

\subsubsection{Perspicácia Harmônica}

Nessas rodas, o que mais se exigia e o que mais se apreciava nos acompanhadores, sobretudo de violão e cavaquinho, era a percepção musical, aptidão consagrada na expressão tocar de ouvido. Gonçalves Pinto quase que em cada página de sua obra menciona o fato: "Ventura Careca: violão de fama, (...) não admitia que lhe desses o tom, tal era a confiança que elle tinha no seu ouvido". Quando o acompanhador não conseguia atinar com a harmonia do solista, dizia-se que tinha caído. Essa expressão foi tão vulgarizada que aparecia no título de polcas como "Caiu, não disse" de Viriato e "Não caio noutra” de Ernesto Nazareth.(...) "Esse hábito de fazer peças difíceis de acompanhar e consignar tal intenção no título conservou-se, bastando para tanto lembrar o Choro "Derrubando Violões”, composto pelo maestro Carioca em 1950. (TABORDA, 2011, p. 130). 
Nesta epígrafe Márcia Taborda destaca a importância da percepção harmônica dos acompanhadores de Choro. Naturalmente, o conhecimento do repertório é um importante aspecto de uma boa performance, como aponta o músico Fernando César (2016, E., p. 26): “O conhecimento do repertório é fundamental pra tocar o V6 no Choro”. No entanto, tradicionalmente, o repertório de uma Roda de Choro não é fixo, de modo que as músicas a serem executadas frequentemente são escolhidas apenas poucos instantes antes de sua execução, frequentemente, pelos solistas. Diante de um imenso repertório, construído ao longo de muitas décadas (e ainda em expansão, naturalmente), torna-se impossível para qualquer músico a tarefa de decorar todas as Harmonias.

Decorre deste fato a necessidade do violonista (ou qualquer outro harmonizador) possuir desenvolvida capacidade em harmonizar as músicas a partir de elementos da melodia ou dos clichês harmônicos. A esta virtude, uma espécie de antevisão do próximo acorde a ser tocado, estou chamando de Perspicácia Harmônica. Ela parece amadurecer naturalmente nos chorões (principalmente com o desenvolvimento da habilidade de reconhecimento de clichês harmônicos, arpejos, escalas ou intervalos), pois a Roda de Choro constitui um cenário propício para esse tipo de desenvolvimento. No depoimento do músico Cidinho 7 Cordas, essa habilidade é destacada na sua vivência pessoal, ao descrever os seus primeiros contatos com o aprendizado de Choro:

Eu entrava nas Rodas de Choro, pedia licença e tentava tirar proveito da melhor forma, perguntava como fazer isto ou aquilo. Em 1959 tocava num clube e o Pixinguinha era o convidado da noite. Foi ótimo! E daí passei a frequentar o Bar do Gouveia onde ele tinha uma cadeira cativa. Ali conheci o Donga e outros grandes músicos que me deixavam tocar... Foi por aí... (CIDINHO 7 CORDAS, 2015, E. p.8)

Sandroni (2000) cita em seu artigo uma série de entrevistas realizadas em 1994, no Rio de Janeiro, com diversos violonistas de Samba e Choro, nas quais os entrevistados ressaltaram a importância da frequentação assídua em rodas de Samba e Choro, salientando a relevância desse aprendizado misturado com a prática. Sandroni (2001, p.7) cita o trabalho didático realizado por Meira, naturalmente influenciado pela prática nas rodas:

No entanto, aqueles que foram alunos de Meira também ressaltaram a importância das aulas do mestre. Ao procurar saber um pouco mais sobre como funcionavam estas aulas, ouvi relatos que mostravam certa continuidade entre o tipo de experiência vivido numa roda de choro e o tipo 
vivido na situação marcada como "didática": de acordo com o depoimento de um dos entrevistados, as aulas de Meira eram "rodas de Choro concentradas". Eram aulas que enfatizavam o tipo de habilidade necessária para um bom desempenho numa roda: capacidade de transpor em tempo real, de acompanhar músicas que não se conhece especialmente bem, de improvisar contracantos nas cordas graves do violão (as famosas 'baixarias') etc.

De forma análoga às Rodas de Choro, os programas de rádio contribuíram para o desenvolvimento desta perspicácia harmônica, principalmente nos anos 30 e nos anos 40. Para tratar do tema, irei propor uma breve contextualização do período em questão. Segundo Lara Filho (2009, p.21), nessa época era comum que cada rádio tivesse o seu próprio regional:

As principais rádios atuantes nas décadas de 1930 e 1940 tinham seus próprios regionais. Eram elas: Rádio Guanabara (Gente do Morro e Jacob e sua gente); Rádio Transmissora (Regional de Claudionor Cruz); Rádio Clube (Waldir Azevedo e seu regional); Rádio Tupi (Regional de Benedito Lacerda e Regional de Rogério Guimarães); Rádio Mayrink Veiga (Regional do Canhoto); Rádio Nacional (Regional de César Moreno e Regional de Dante Santoro).

Além disso, os Regionais eram um importante fator de indicativo da qualidade das rádios, como podemos notar no texto “A história dos regionais”, de Sérgio Prata (2005): "Entre meados dos anos 30 e o final da década de 50, um vetor da qualidade de uma emissora de rádio era o seu regional. Nessa época, os lugares nos programas de auditório eram disputados pelos fã-clubes dos artistas”.

O depoimento do ilustre pandeirista do Conjunto Época de Ouro, concedido ao Sérgio Prata, torna ainda mais precisa a ideia da importância dos regionais "Segundo Jorginho do Pandeiro, o sucesso era tanto que as gravadoras organizavam as agendas de seus astros de acordo com a disponibilidade que o Regional do Canhoto tinha para gravar”. (PRATA, 2005)

Nesse contexto de trabalho, era exigida uma grande desenvoltura prática dos músicos dos regionais, pois, além dos trabalhos regulares e das gravações, os regionais precisavam “corrigir” a programação quando algum imprevisto ocorria, como aponta Cazes (1998, p.85):

O acordeonista e arranjador Orlando Silveira conta que "quando havia algum problema e falhava a programação, o regional era chamado e muitas vezes o cantor dizia o tom e nós entrávamos tocando sem conhecer a música, fazendo introdução na hora, harmonizando na hora”. Diversos músicos que viveram esse período dos regionais de rádio apontam essa prática como sua grande escola. 
Portanto, a necessidade de se "virar" com as Harmonias esteve presente desde as primeiras Rodas de Choro, tendo sido exponenciada pela dinâmica da atuação dos regionais nas rádios. Tal habilidade de intuir com destreza a Harmonia - aquilo que estou chamando de Perspicácia Harmônica - ainda hoje é exigida dos músicos de Choro, e o tema constantemente apareceu nas entrevistas, como podemos observar no depoimento do músico Valério de Sousa (2015, E., p. 38), ao comentar as “habilidades harmônicas” do músico Alencar 7 Cordas: “(...) o Alencar era muito intuitivo, o Jonas sempre falou que ele tinha uma antena poderosa”. Dino 7 Cordas já havia se pronunciado sobre o assunto, ao comentar as dificuldades de se harmonizar determinadas músicas:

(...) naquela época se fazia muita música pra derrubar os acompanhadores. Isso eram os solistas, eles gostavam de fazer isso. Então o Candinho me fez uma música com esse nome: $\mathrm{O}$ nó. Diz-se que foi um pau danado nesse dia em que foram tocar essa música (...). O fato é que o negócio come feio mesmo. (ÉPOCA DE OURO, Programa Ensaio, 1973).

Destaco, portanto, a Perspicácia Harmônica como uma importante característica desenvolvida pelos chorões ao longo de seu desenvolvimento musical, dentro da habilidade mais ampla que é a realização de Harmonias. Ao que indicam as entrevistas, o contexto da Roda de Choro e a constante prática de tirar músicas de ouvido contribuem para o amadurecimento de tal habilidade, considerada como essencial pelos chorões entrevistados.

Em seu livro A mente musical (2008), Sloboda recorre ao experimento realizado com o tabuleiro de xadrez para atentar sobre a exposição ao material musical. Neste experimento, vários jogadores, experts e principiantes, são desafiados a memorizar diferentes configurações de peças no tabuleiro. Notou-se que, quando expostos a tabuleiros configurados aleatoriamente, não houve grande variação de acertos entre o grupo de experts e o grupo de iniciantes. No entanto, quando expostos a tabuleiros configurados com "situações reais" de um jogo, o grupo de experts obteve um êxito muito maior. Em uma analogia entre o tabuleiro de xadrez "real” e as ocorrências harmônicas “reais”, naturalmente, é possível admitir a existência de clichês harmônicos em nossa música, inclusive no Choro. Segundo Mário de Andrade, "os portugueses fixaram o nosso tonalismo harmônico, nos deram a quadratura estrófica” (ANDRADE, 1977, p.185). Essa quadratura, herdada pelo Choro (8 ou 16 compassos), somada ao tonalismo e à estrutura melódica das frases podem auxiliar na procura pelo próximo acorde a ser tocado. 
Aprofundando nesta perspectiva, por meio de sua reconhecida habilidade de sintetização, o grande músico e professor Alencar Soares (conhecido por Alencar 7 Cordas) dedicou-se a recolher situações harmônicas recorrentes e classificá-las. O trabalho, ainda não publicado, ficou conhecido como a Teoria das Árvores Harmônicas. Neste trabalho, Alencar se propõe a descrever os clichês harmônicos mais recorrentes, em consonância com os tabuleiros em situações reais de jogo de Sloboda. Ou seja, a partir dos encadeamentos da Harmonia Funcional, é possível expor o ouvido a materiais musicais relevantes que podem auxiliar no armazenamento de "padrões harmônicos” do Choro.

Segue abaixo um exemplo retirado do trabalho Teoria das Árvores Harmônicas de Alencar 7 Cordas (no prelo) que ilustra dois importantes clichês frequentemente utilizados no Choro em tonalidades maiores.

Figura 11 - Clichês harmônicos em tonalidades maiores

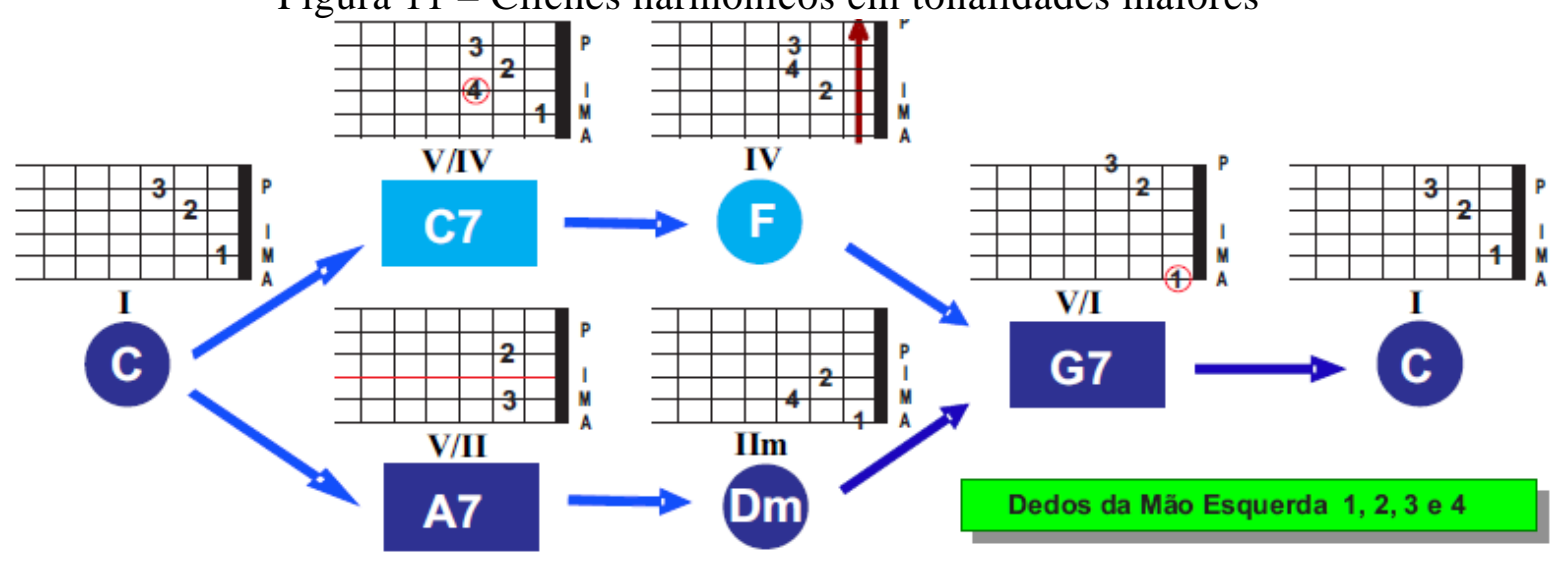

Fonte: Alencar 7 Cordas, Teoria das Árvores Harmônicas (no prelo).

A parte superior da figura 11 apresenta a situação harmônica de ida para o IV grau ${ }^{26}$. Este contexto harmônico (I V/IV IV) é percebido em muitos Choros. Alencar 7 Cordas se referia a essa situação como o caminho da árvore “por cima”.

Na parte inferior da figura 11, outra situação harmônica, bastante recorrente nos Choro, é observada com a ida ao II grau da tonalidade e o retorno ao acorde inicial através do acorde dominante: I V/II II V (C A7 Dm G7 C na tonalidade de C). Esta situação pode ser observada em:

\footnotetext{
${ }^{26}$ O professor Alencar 7 Cordas assim descreve especificamente esta situação: "Fique atento ao cantor. Se ele levantar o braço, é muito provável que a Harmonia esteja indo para o IV grau numa tonalidade maior” (Soares, no prelo). Ao analisar as melodias de Choro (e de Samba) pude notar que os picos, normalmente a nota mais aguda, frequentemente estão no momento em que a Harmonia vai para o IV grau, ou seja, no momento em que o cantor enche o peito e coloca força em sua interpretação ("o momento em que ele levanta o braço"). Tal clichê também se aplica ao Choro, com a devida correspondência entre o cantor no Samba e o solista no Choro.
} 
Figura 12 - clichê harmônico em tonalidades maiores.

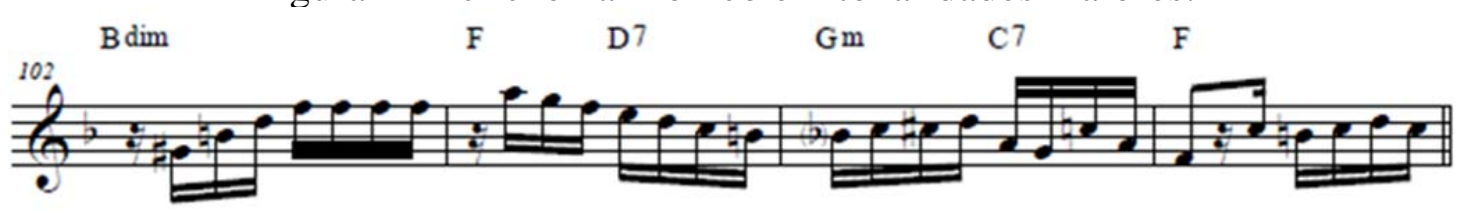

Fonte: Seu Lourenço no vinho, transcrição do autor

A ocorrência do clichê I V/II II V I é observado na figura acima, neste caso na tonalidade de F a partir do compasso 103.

Convém apontar uma importante variação deste clichê harmônico, em que o II é substituído pelo dominante secundário V/V, popularmente conhecido como quinta da quinta, resultando no encadeamento I V/II V/V V. Esta situação ocorre em:

Figura 13 - variação do clichê harmônico em tonalidades maiores.

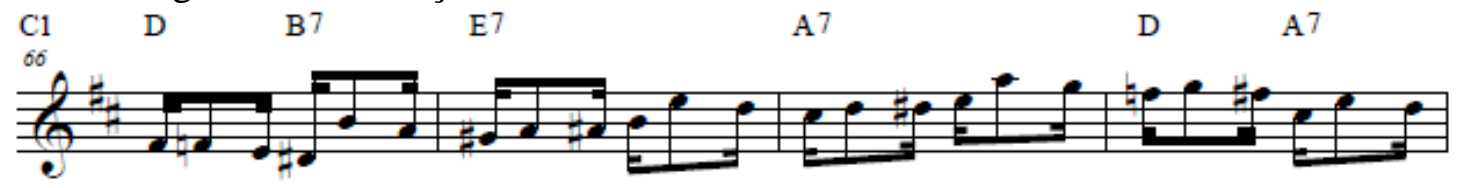

Fonte: Chorinho na praia, transcrição do autor

Na parte inferior da figura acima é executada a frequente variação do clichê harmônico. Neste caso, ocorre a substituição do acorde Em (II) pelo acorde E7 (V/V).

Quanto à exposição da árvore harmônica básica das tonalidades menores, Alencar 7 Cordas (no prelo) apresenta a seguinte estrutura:

Figura 14 - Clichês harmônicos em tonalidades menores.

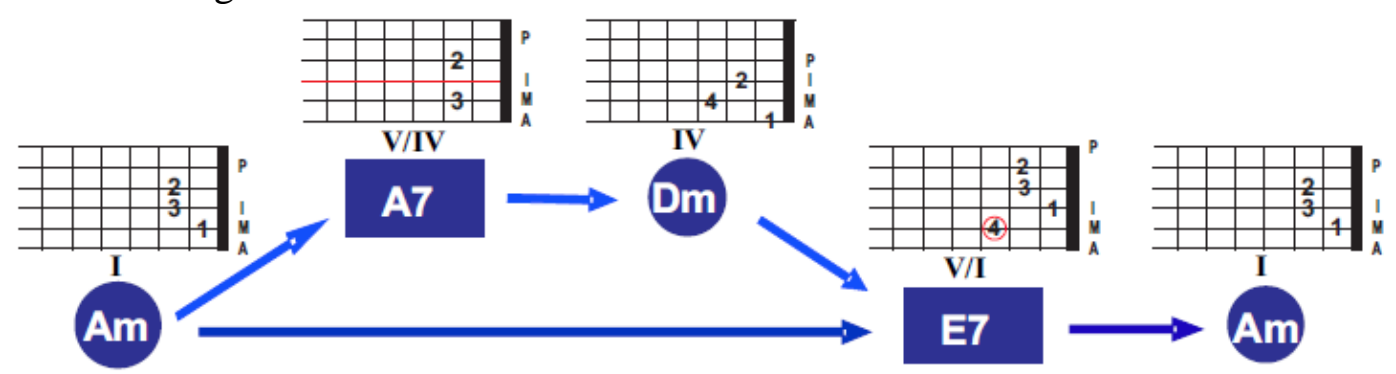

Fonte: Alencar 7 Cordas, Teoria das Árvores Harmônicas (no prelo).

Na figura acima, dois clichês harmônicos, relacionados às tonalidades menores, podem ser observados. Na parte inferior, destaca-se o encadeamento Am E7 Am, uma situação básica que o chorão precisa reconhecer desde muito cedo, a função tônica e a função dominante (I-V - I). 
Figura 15 - Clichê harmônico em tonalidade menor - exemplo.
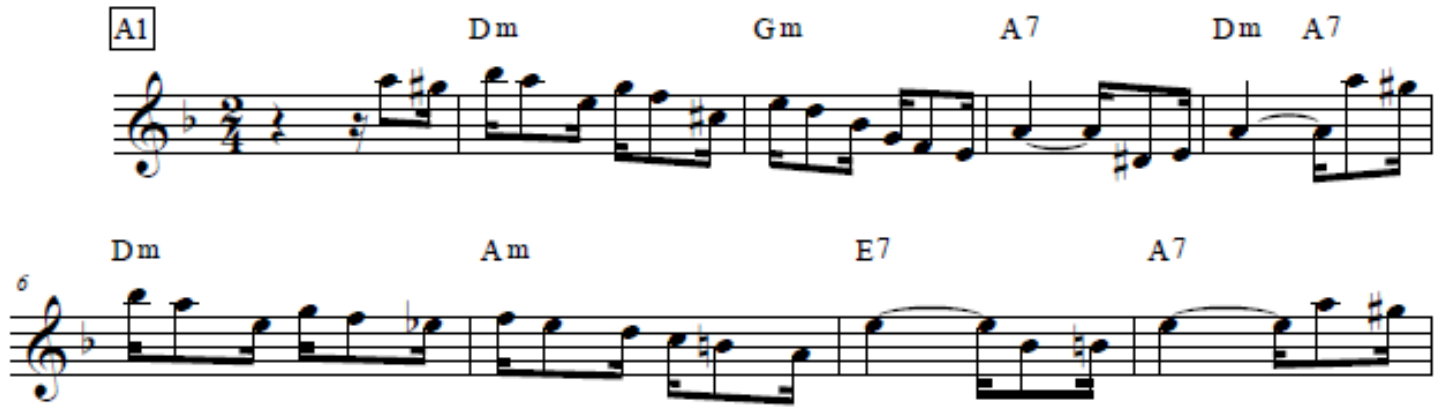

Fonte: Chorinho na Praia, transcrição do autor.

Na figura acima, nos compassos 5 e 6, a passagem harmônica I V I é executada como Dm A7 Dm, passagem bastante comum em tonalidades maiores e menores.

Em seguida, a análise da figura 14 (clichês) aponta em sua parte superior a ida ao IV grau e o retorno ao I grau por meio do V grau: Am A7 Dm E7 Am (I V/IV IV V I). Nas aulas que pude ter com o professor Alencar 7 Cordas, ele, por diversas vezes, ressaltou a importância do IV na tonalidade menor e a grande probabilidade de sua ocorrência.

Esses dois clichês apresentados na árvore harmônica podem se combinar em outro, também bastante recorrente: I V I V/II II V/II II. Esta combinação se destaca na música Vibrações:

Figura 16 - Clichê harmônico em tonalidade menor no Choro $\begin{array}{lllllll}\mathrm{Dm} & \mathrm{A} 7 & \mathrm{Dm} & \mathrm{D} 7 & \mathrm{Gm} & \mathrm{D} 7 & \mathrm{Gm}\end{array}$

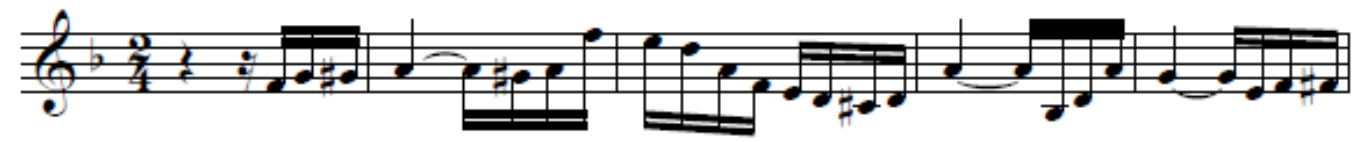

A 7 $\mathrm{Dm} \quad \mathrm{A} 7 \quad \mathrm{Dm}$

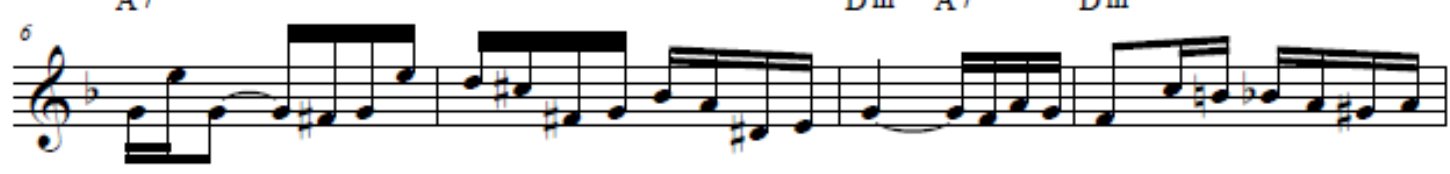

Fonte: Vibrações, transcrição do autor.

A figura acima, portanto, apresenta os clichês das tonalidades menores da Árvore Harmônica combinados. Do compasso 2 até o primeiro tempo do compasso 3 o clichê I - V I (Dm - A7 - Dm) é observado. Do primeiro tempo do compasso 3 em diante o outro clichê harmônico I V/IV IV V I (Dm - D7 - Gm - A7 - Dm) é executado, ressaltando que nos compassos 4 e 5 ocorre uma nova preparação para o IV antes de chegar ao $\mathrm{V}$ de fato no compasso 6. 
O professor Alencar 7 Cordas atenta ainda para uma espécie de compartilhamento de clichês entre uma tonalidade e a sua tonalidade relativa.

Figura 17 - Clichês “compartilhados” entre C e Am.

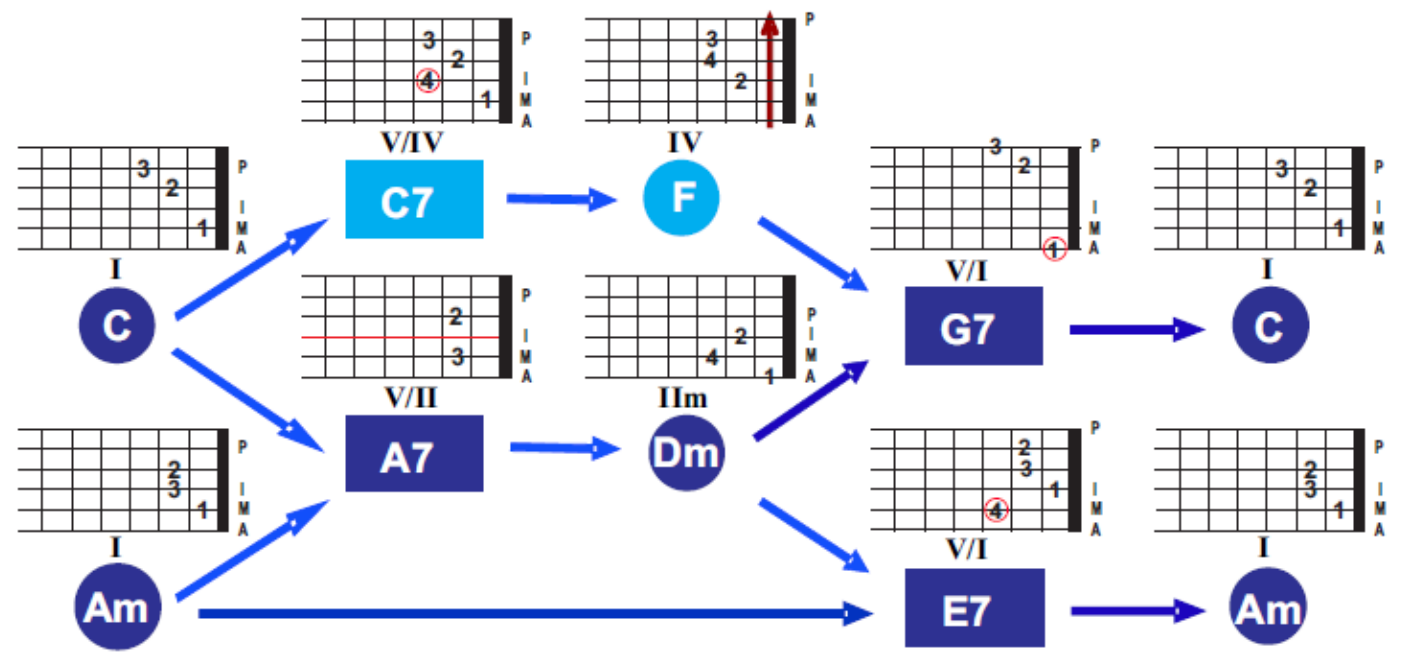

Fonte: Alencar 7 Cordas, Teoria das Árvores Harmônicas (no prelo).

Na figura acima é possível observar que parte dos clichês apresentados numa tonalidade e sua tonalidade relativa é simultaneamente dividida entre elas. Na tonalidade da modelo acima, os acordes de A7 e Dm fazem partes das duas sequências harmônicas, tanto do clichê inferior de C quanto do clichê superior de Am.

Naturalmente são vários os padrões harmônicos a serem assimilados pelo chorão. Em sua Teoria das Árvores Harmônicas, o professor Alencar 7 Cordas destaca também as modulações como outro aspecto bastante relevante em relação à capacidade de “intuição" da Harmonia. Neste aspecto, ele se propôs a indicar as modulações mais recorrentes.

\subsubsection{Modulações}

Antes de entrar especificamente no assunto da modulação no Choro, convém fazer uma breve discussão sobre o tema. Segundo o músico Almir Chediak (1986, p.116) “uma modulação é a passagem de uma tonalidade para outra na harmonia de uma música tomando como base o sistema tonal. A modulação ocorre quando não podemos analisar um ou mais acordes dentro da tonalidade primitiva”.

Cabe ainda diferenciar uma modulação de uma modulação passageira. Esta ocorre dentro de uma das partes da música, frequentemente retornando à tonalidade original 2 ou 3 compassos depois. A modulação (não passageira) está sendo vista como um processo 
estrutural, normalmente vinculado à mudança entre as partes da música, numa visão mais ampla da forma.

\subsubsection{Modulações passageiras}

O professor Alencar 7 Cordas assim relacionou as principais modulações passageiras, ou seja, aquelas que acontecem internamente em uma parte da forma da música:

Figura 18 - Modulações passageiras em tonalidades maiores.

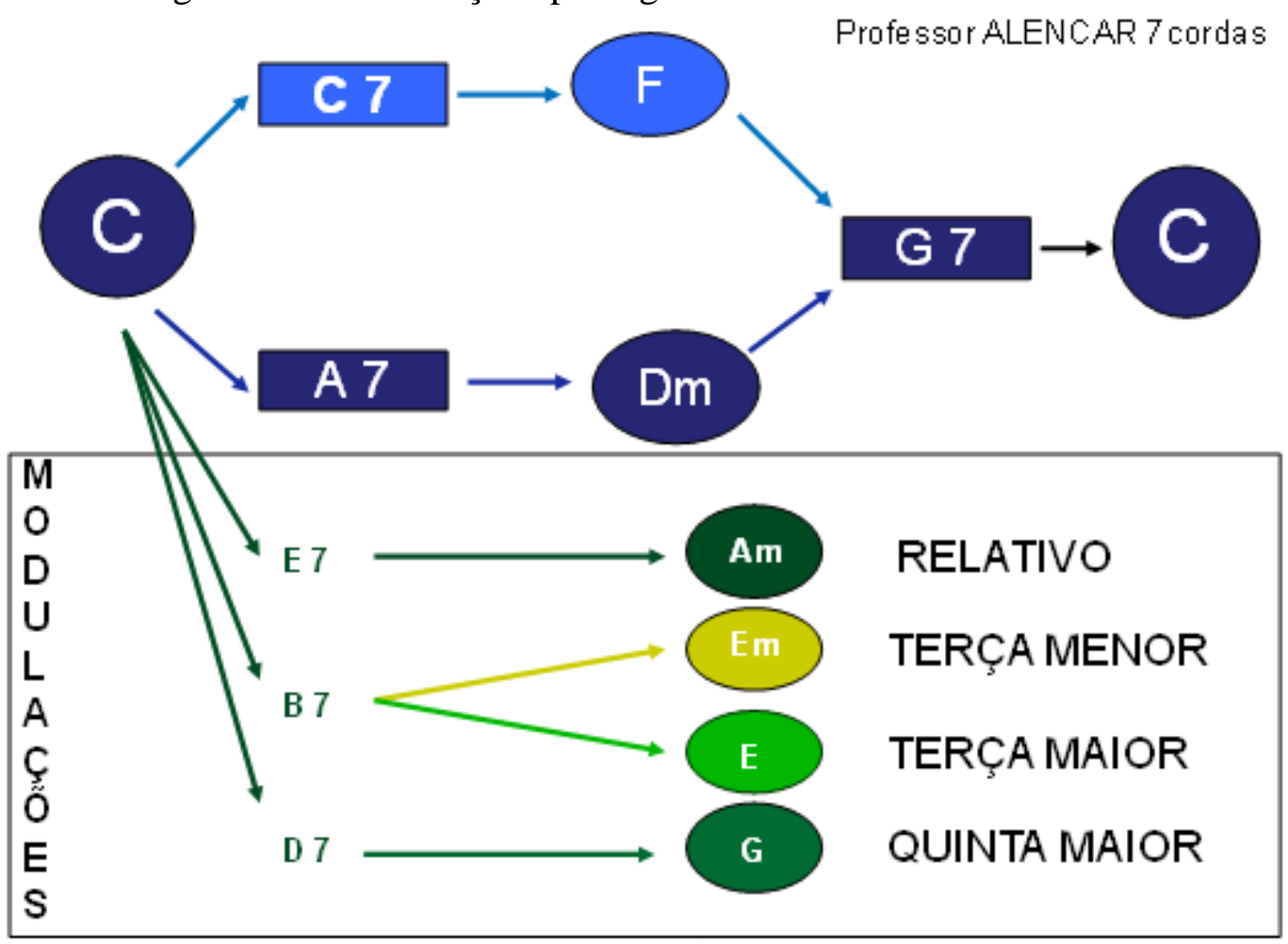

Fonte: Alencar 7 Cordas, Teoria das Árvores Harmônicas (no prelo).

Na figura acima, são apresentadas as principais modulações passageiras relacionadas por Alencar 7 Cordas para as tonalidades maiores. As modulações podem ou não ocorrer com o auxílio do acorde dominante preparatório. Na primeira modulação, indicada no canto superior das modulações na figura 18, ocorre a passagem ao tom relativo menor. Essa modulação é reconhecida nos seguintes exemplos: 
Figura 19 - Modulação para o relativo
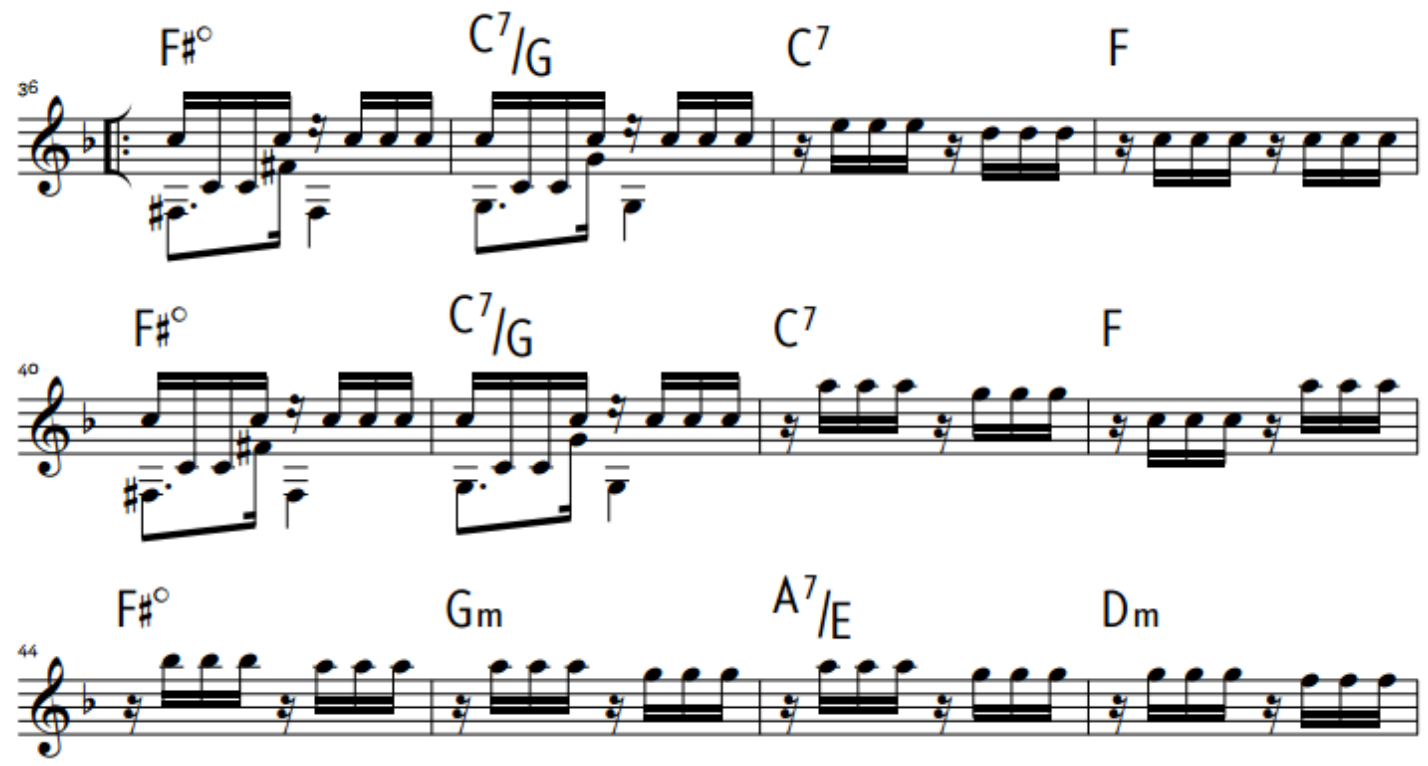

Fonte: Ernesto Nazareth, Odeon.

A segunda modulação apontada na figura 18 demonstra a passagem ao III: I V/III III. Este tipo de modulação pode ser observado no exemplo seguinte, extraído do Choro Flor Amorosa de Joaquim Callado:

Figura 20 - Modulação para o III.

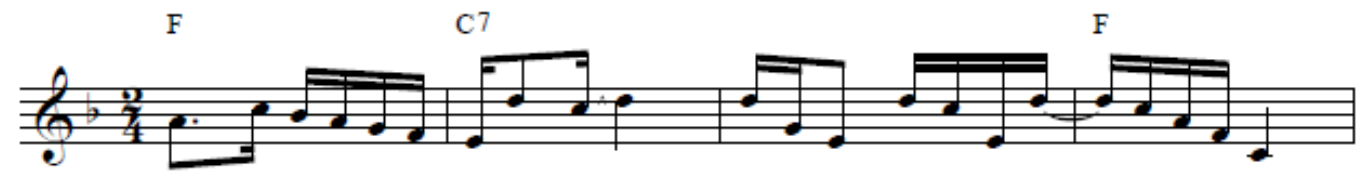

$\begin{array}{llllll}\mathrm{F} & \mathrm{Bm} 7(35) & \mathrm{Am} & \mathrm{Em} & \mathrm{Am} & \mathrm{C}\end{array}$

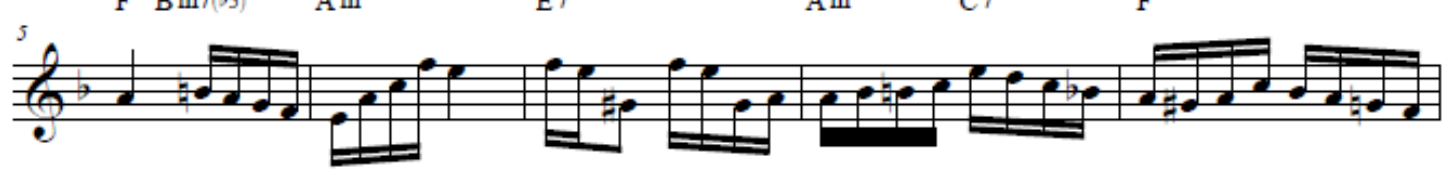

Fonte: Chediak, 2007, p.143

No exemplo acima ocorre a passagem da tonalidade original (F) para o seu III (Am) no compasso 6. No compasso 8 a tonalidade original é novamente preparada, por meio do $\mathrm{V}$ (C7). A análise harmônica pode ser vista como:

Quadro 2 - Encadeamentos Harmônicos

$$
\frac{\text { I - V - V - I }}{\text { I II/III - I' - V/I' - I' V - I }}
$$


Fonte: Análise do autor

Na análise apresentada, I é a tonalidade original (F) e I' é a nova tonalidade (Am), correspondente ao III da tonalidade original.

Na terceira modulação, uma modulação mais forte é realizada, por se tratar de uma modulação para um acorde estranho à tonalidade, o III maior. Exemplo:

Figura 21 - Modulação para o III maior.
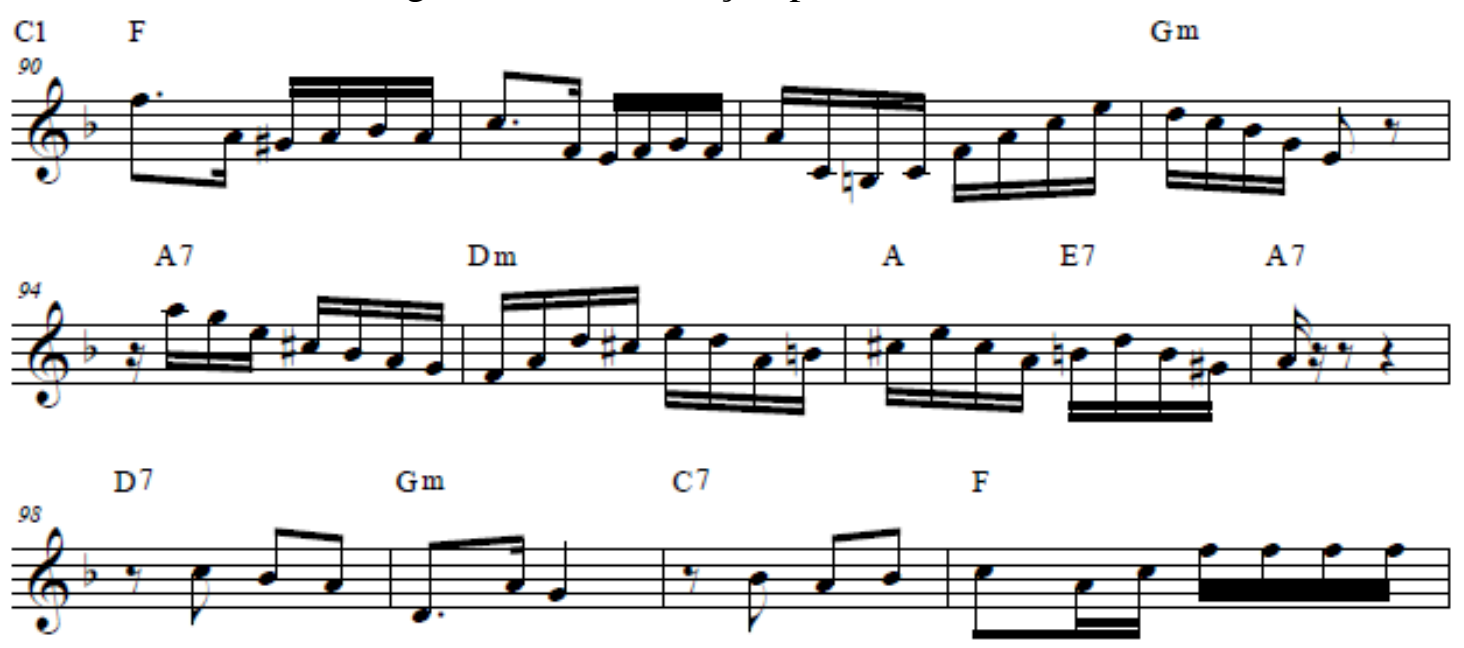

Fonte: Seu Lourenço no vinho, transcrição do autor.

Na figura acima, o trecho musical modula de F para A (III maior) no compasso 96. Após estabilizar na nova tonalidade com a exposição do V (E7), a melodia retorna da modulação passageira à tonalidade de F a partir do V/II (D7).

Quadro 3 - Modulação para o III maior.

\begin{tabular}{|c|}
\hline I - I - I - II \\
\hline V/VI - VI - I' V/I' - V/VI \\
\hline V/II - II - V - I \\
\hline
\end{tabular}

Fonte: Análise do autor.

Na análise apresentada, I é a tonalidade original (F) do trecho, e I' é a nova tonalidade (A), correspondente ao III maior de F. A quarta modulação é bastante recorrente e pode ser observada em Chorinho na praia:

Figura 22 - Modulação para o V em tonalidade maior. 

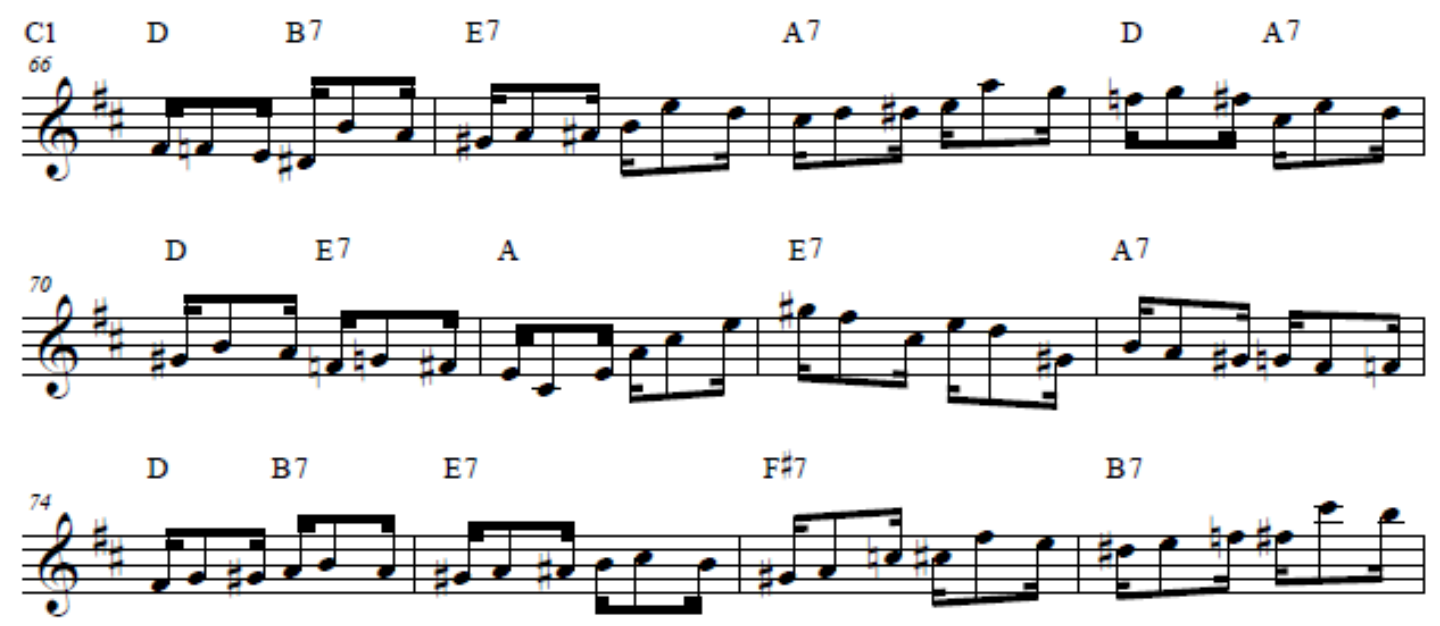

Fonte: Chorinho na praia, transcrição do autor.

No trecho musical acima ocorre a modulação da tonalidade de D para a tonalidade de $\mathrm{A}(\mathrm{V})$ no compasso 71. Vale notar que a música volta à tonalidade original de $\mathrm{D}$ no compasso 74, reforçando o caráter passageiro da modulação. Funcionalmente, a Harmonia do trecho pode ser vista como:

Quadro 4 - Análise de trecho com modulação para o V.

\begin{tabular}{|c|}
\hline $\mathrm{I}$ V/II $-\mathrm{V} / \mathrm{V}-\mathrm{V}-\mathrm{I} \mathrm{V}$ \\
\hline $\mathrm{I} \mathrm{V} / \mathrm{V}(\mathrm{ou} \mathrm{V} / \mathrm{I}$ ') $-\mathbf{I} \mathbf{-}$ - V/I' $-\mathrm{V}$ \\
\hline $\mathrm{I} \mathrm{V} / \mathrm{II}-\mathrm{V} / \mathrm{V}-\mathrm{V} / \mathrm{VI}-\mathrm{V} / \mathrm{II}$ \\
\hline
\end{tabular}

Fonte: Análise do autor.

Na análise em questão, I é a tonalidade original (D) e A, V da tonalidade original, é a nova tonalidade (I').

Alencar 7 Cordas sintetizou também a Árvore Harmônica das tonalidades menores, com alguns paralelos em relação à Árvore Harmônica das tonalidades maiores:

Figura 23 - Modulações passageiras em tonalidades menores. 


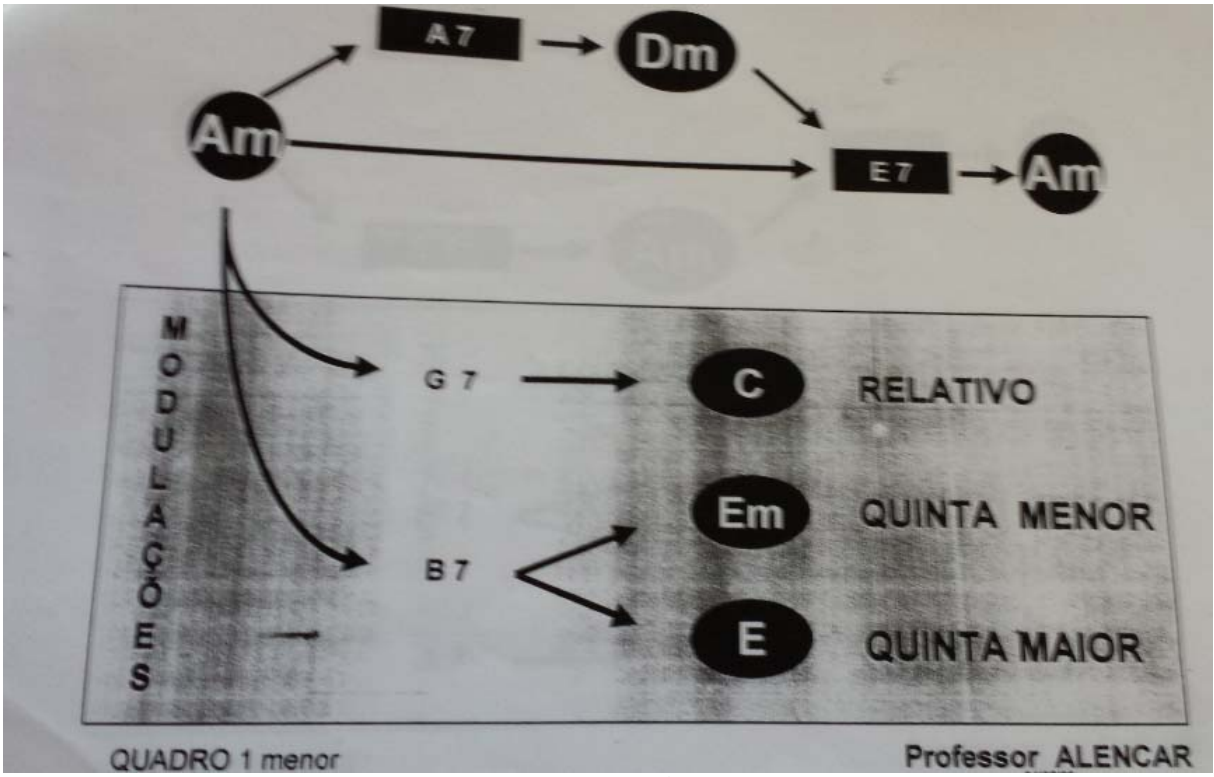

Fonte: Alencar 7 Cordas, Teoria das Árvores Harmônicas (no prelo).

O exemplo abaixo ilustra a passagem pelo relativo (III) da tonalidade menor:

Figura 24 - Modulação passageira para o relativo em tonalidade menor.
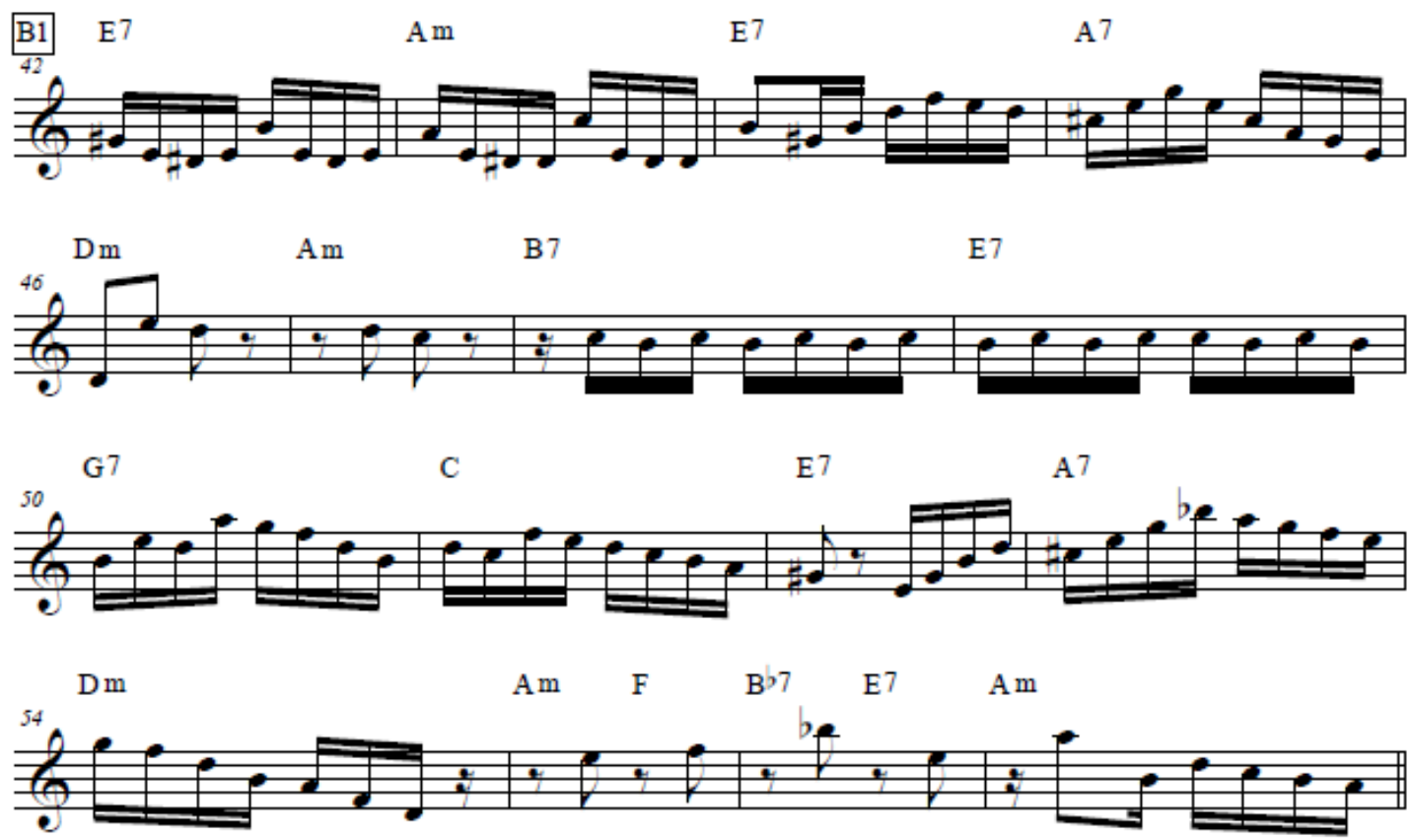

Fonte: Seu Lourenço no vinho (Pixinguinha), transcrição do autor.

O trecho acima, na tonalidade de Am, chega à tonalidade relativa (C) por meio do dominante (G7) no compasso 50. No compasso 52, é executado o dominante da tonalidade original (E7) que, no entanto, não resolve imediatamente em Am, passando antes da resolução 
pelo dominante do IV (A7) e pelo IV (Dm). Uma análise funcional a partir do compasso 42 pode ser:

Quadro 5 - Análise do trecho com modulação para o relativo.

\begin{tabular}{|c|}
\hline $\mathrm{V}-\mathrm{I}-\mathrm{V}-\mathrm{V} / \mathrm{IV}$ \\
\hline $\mathrm{IV}-\mathrm{I}-\mathrm{V} / \mathrm{V}-\mathrm{V}$ \\
\hline V/I' - I' - V/IV \\
\hline IV - I VI - subV V - I; \\
\hline
\end{tabular}

Fonte: Análise do autor.

No esquema harmônico acima, I é a tonalidade original (Am) e I' é a nova tonalidade (C). O próximo exemplo ilustra a modulação passageira para o Vm:

Figura 25 - Modulação passageira para o Vm em tonalidade menor.
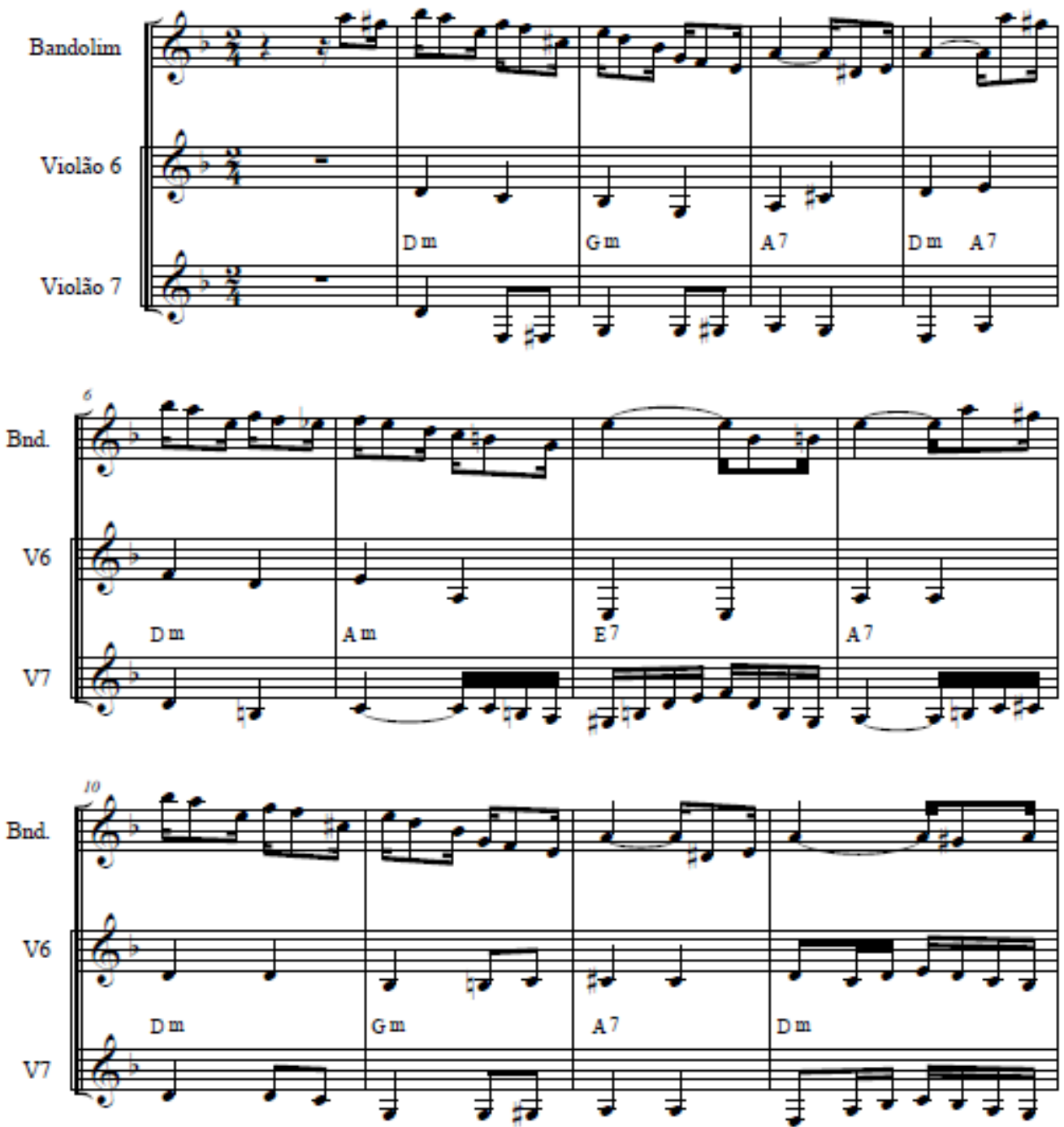

Fonte: Chorinho na praia, transcrição do autor. 
Na figura acima, o trecho em Dm modula para Am no compasso 7. De certa forma, a modulação é preparada pelo baixo do V7 no segundo tempo do compasso 6, quando ele realiza o acorde Bm7(b5) - que é o subdominante (II) de Am. No compasso 9, após o reforço da nova tonalidade no compasso 8, ocorre a preparação da volta à tonalidade original através de seu dominante A7. Uma possível análise funcional da Harmonia é:

Quadro 6 - Análise do trecho com modulação para o Vm.

\begin{tabular}{|c|}
\hline $\mathrm{I}-\mathrm{IV}-\mathrm{V}-\mathrm{IV}$ \\
\hline $\mathrm{I}\left(\mathrm{II} / \mathrm{I}^{\prime}\right)-\mathrm{I}^{\prime}-\mathrm{V} / \mathbf{I}^{\prime}-\mathrm{V}$ \\
\hline $\mathrm{I}-\mathrm{IV}-\mathrm{V}-\mathrm{I} ;$ \\
\hline
\end{tabular}

Fonte: Análise do autor.

Neste esquema, I é a tonalidade original (Dm) e I' é a nova tonalidade (Am), correspondente ao $\mathrm{Vm}$ de $\mathrm{I}$. O próximo trecho representa a modulação ao $\mathrm{V}$ de uma tonalidade menor:

Figura 26 - Modulação passageira para o V em tonalidade menor.
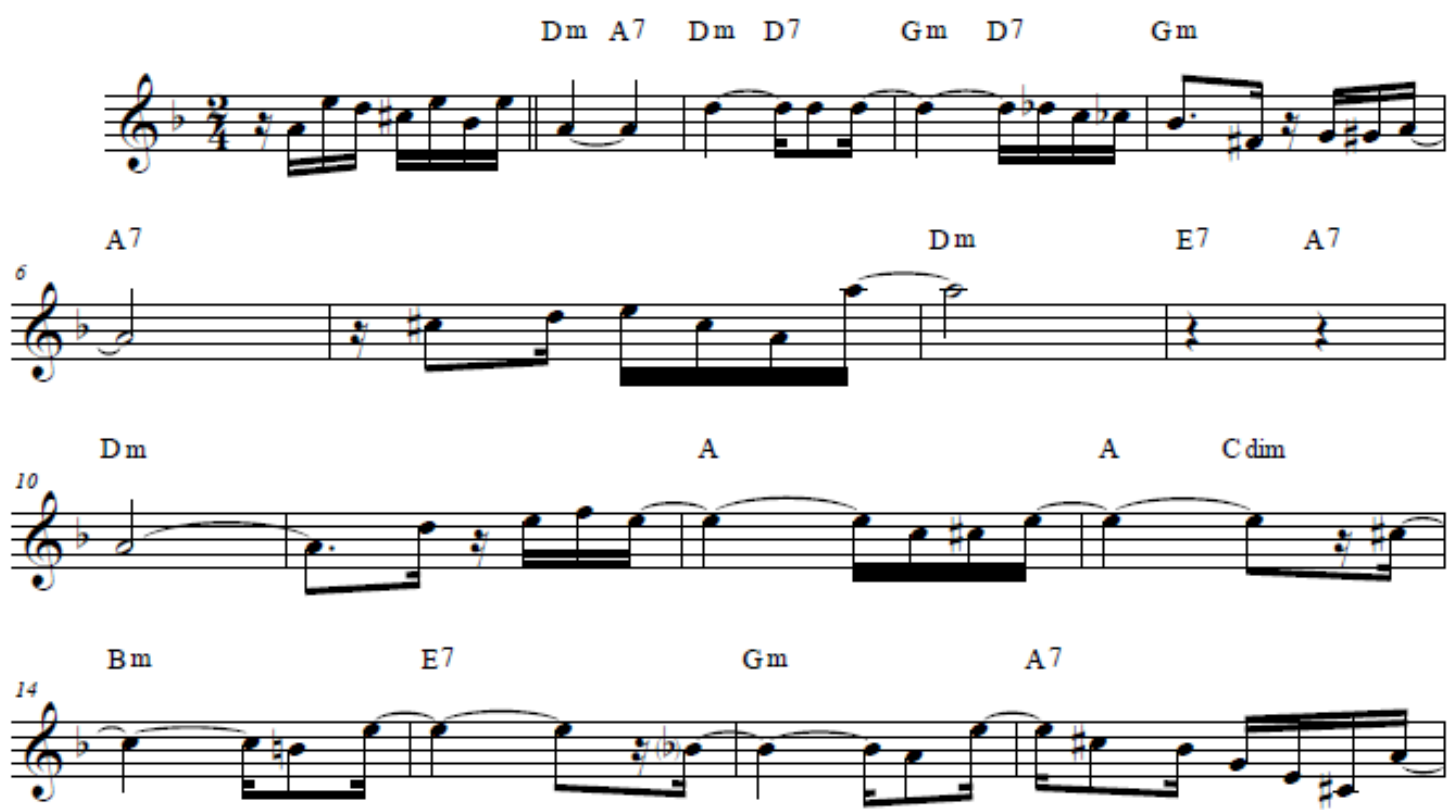

Fonte: Murmurando, (Fon-Fon/Mário Rossi), transcrição do autor.

\subsubsection{Modulações entre partes}

Em relação à modulação entre partes das peças, é possível observar que elas ocorrem com maior frequência para tonalidades relativas, homônimas, subdominantes (IV) e 
dominantes (V). Modulações para tonalidades relativas podem ser observadas no trecho musical de Seu Lourenço no vinho a seguir:

Figura 27 - Modulação para tonalidade relativa - exemplo 1 (tom maior para relativo
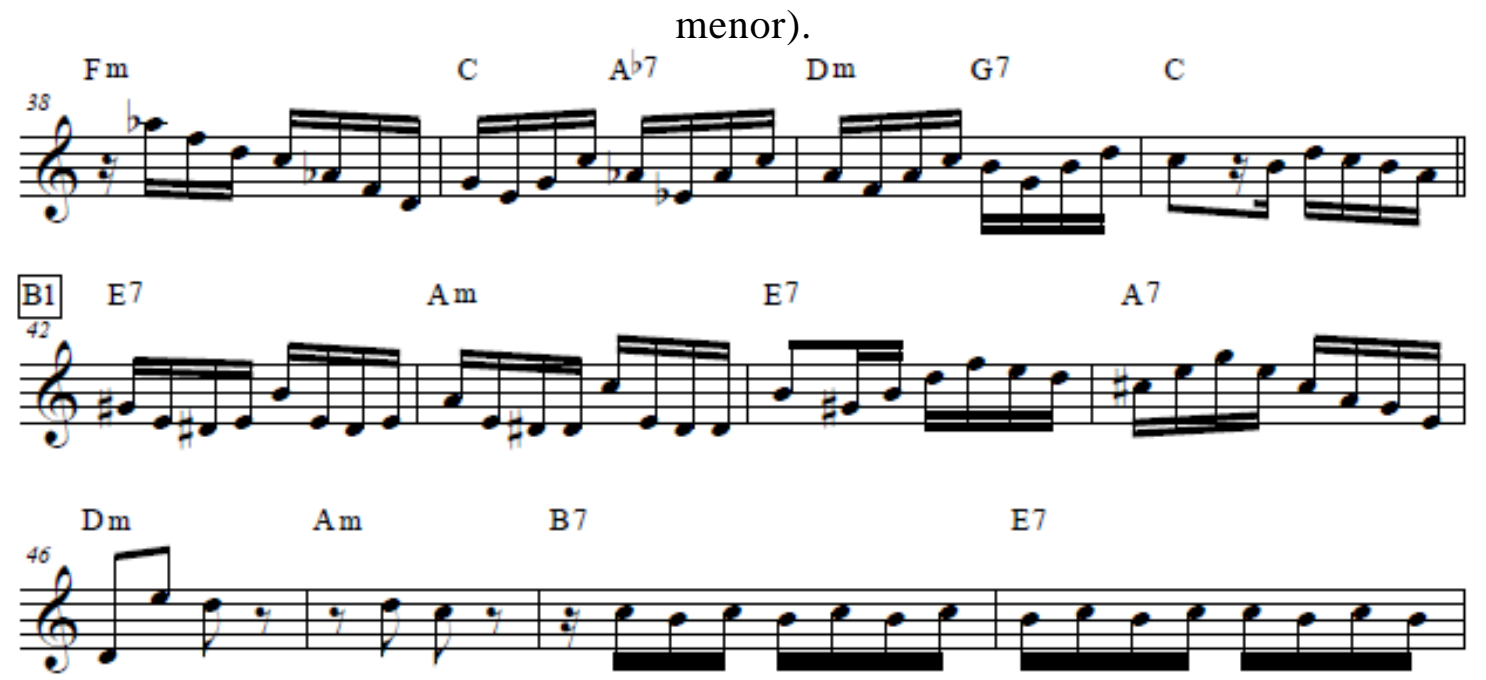

Fonte: Seu Louenço no vinho (Pixinguinha), transcrição do autor.

Na figura 27 ocorre, na mudança da parte A para a parte B, a modulação de C para Am, ou seja, a modulação para o relativo menor. No próximo exemplo, retirado da música Vibrações, ocorre situação inversa:

Figura 28 - Modulação para tonalidade relativa - exemplo 2 (tom menor para relativo maior). 

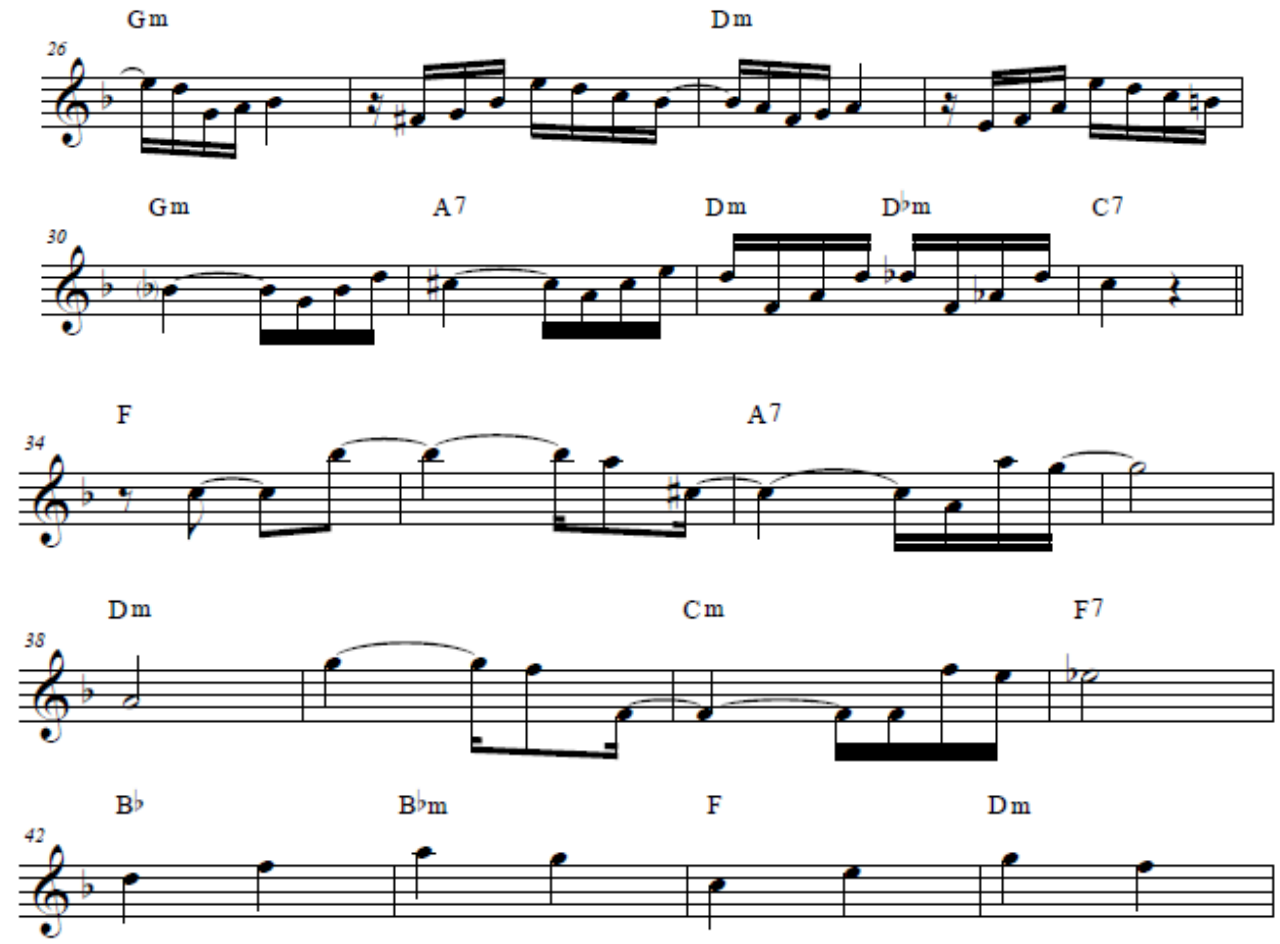

Fonte: Vibrações, transcrição do autor.

No exemplo apresentado acima, a modulação de Dm para o seu relativo maior, F, no compasso 34, ocorre na passagem da parte A para a parte B.

As modulações para tonalidades homônimas são, da mesma forma, muito recorrentes e podem ser observadas em Chorinho na praia:

Figura 29 - Modulação para tonalidade homônima - exemplo 1 (tom menor para tom maior).

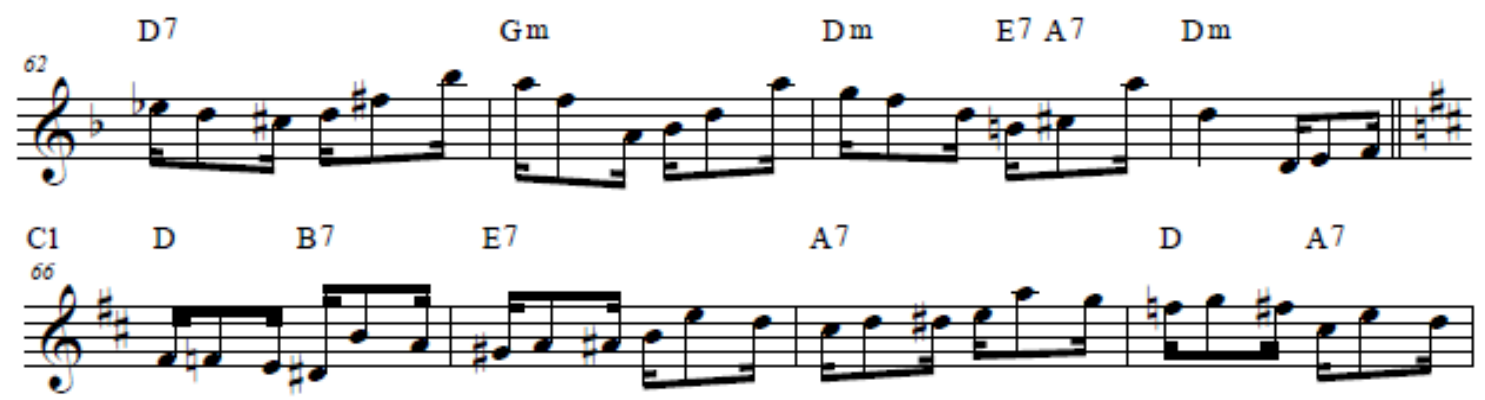

Fonte: Chorinho na praia, transcrição do autor.

Na figura acima, a modulação de Dm da parte A para D (homônimo maior) na parte C é observada. No trecho musical abaixo ocorre o oposto, ou seja, a modulação de uma tonalidade maior para o homônimo menor: 
Figura 30 - Modulação para tonalidade homônima - tom maior para tom menor.

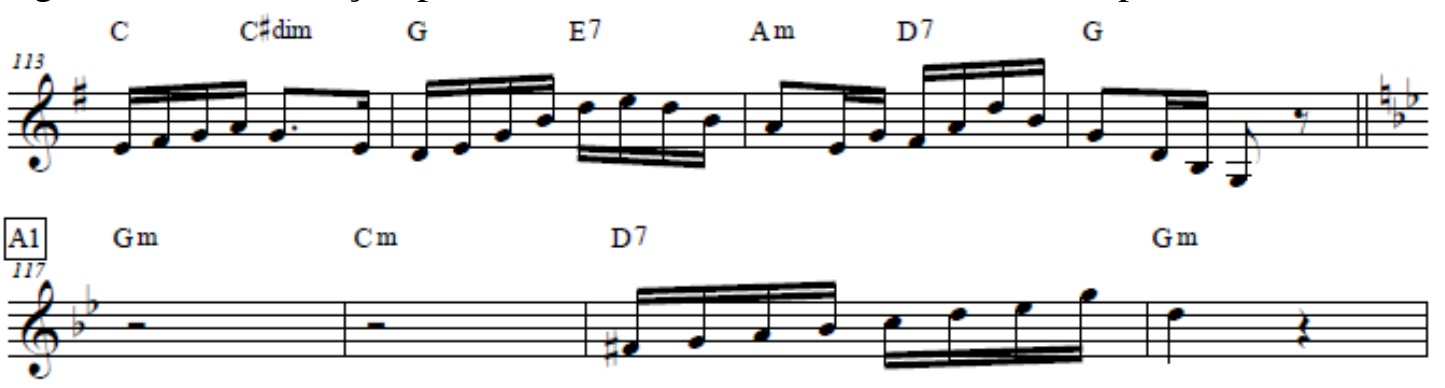

Fonte: Enigmático, transcrição do autor.

O exemplo acima descreve a modulação de uma tonalidade maior (G) para o seu homônimo menor (Gm).

A modulação para o subdominante também é frequente, sobretudo nos choros de 3 partes. Podemos observar este tipo de modulação no exemplo a seguir:

Figura 31 - Modulação para o IV - exemplo 1: tom maior.

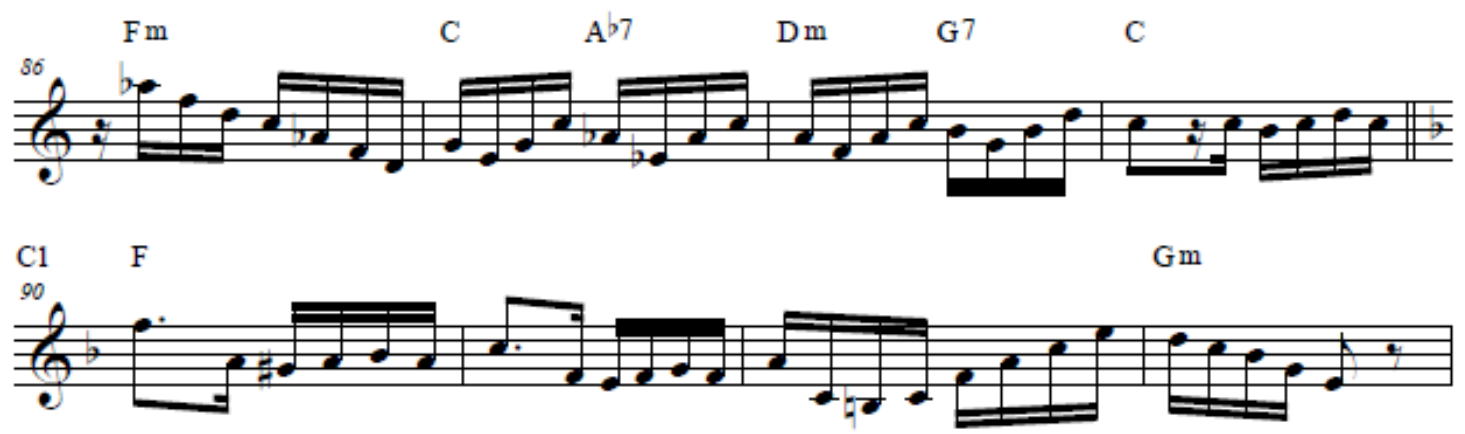

Fonte: Seu Lourenço no vinho, transcrição do autor.

Na figura acima se executa a modulação da tonalidade de C da parte A para a tonalidade de F (IV) da parte C.

E por fim, um exemplo da modulação para o V da tonalidade, observada em Brejeiro, de Ernesto Nazareth:

Figura 32 - Modulação para o V - exemplo 1 (tonalidade maior). 

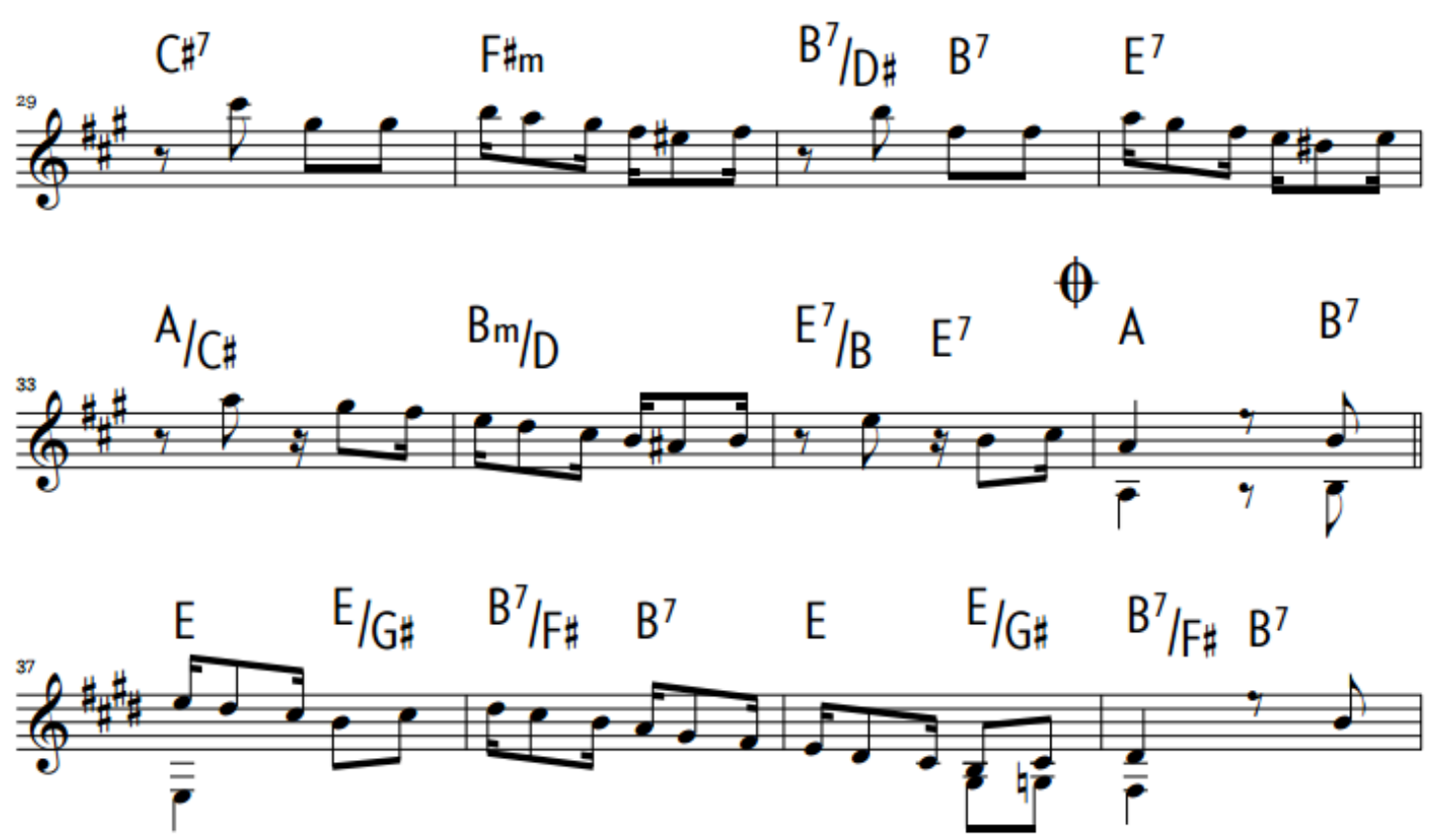

Fonte: Ernesto Nazareth, Brejeiro, 1893 (adaptada).

A modulação de A para E (V de A) no trecho musical de Brejeiro ocorre na mudança da parte A para a parte B, com a ocorrência do dominante de E (B7) no compasso 32.

Figura 33 - Modulação para o Vm - exemplo 2 (tonalidade menor).
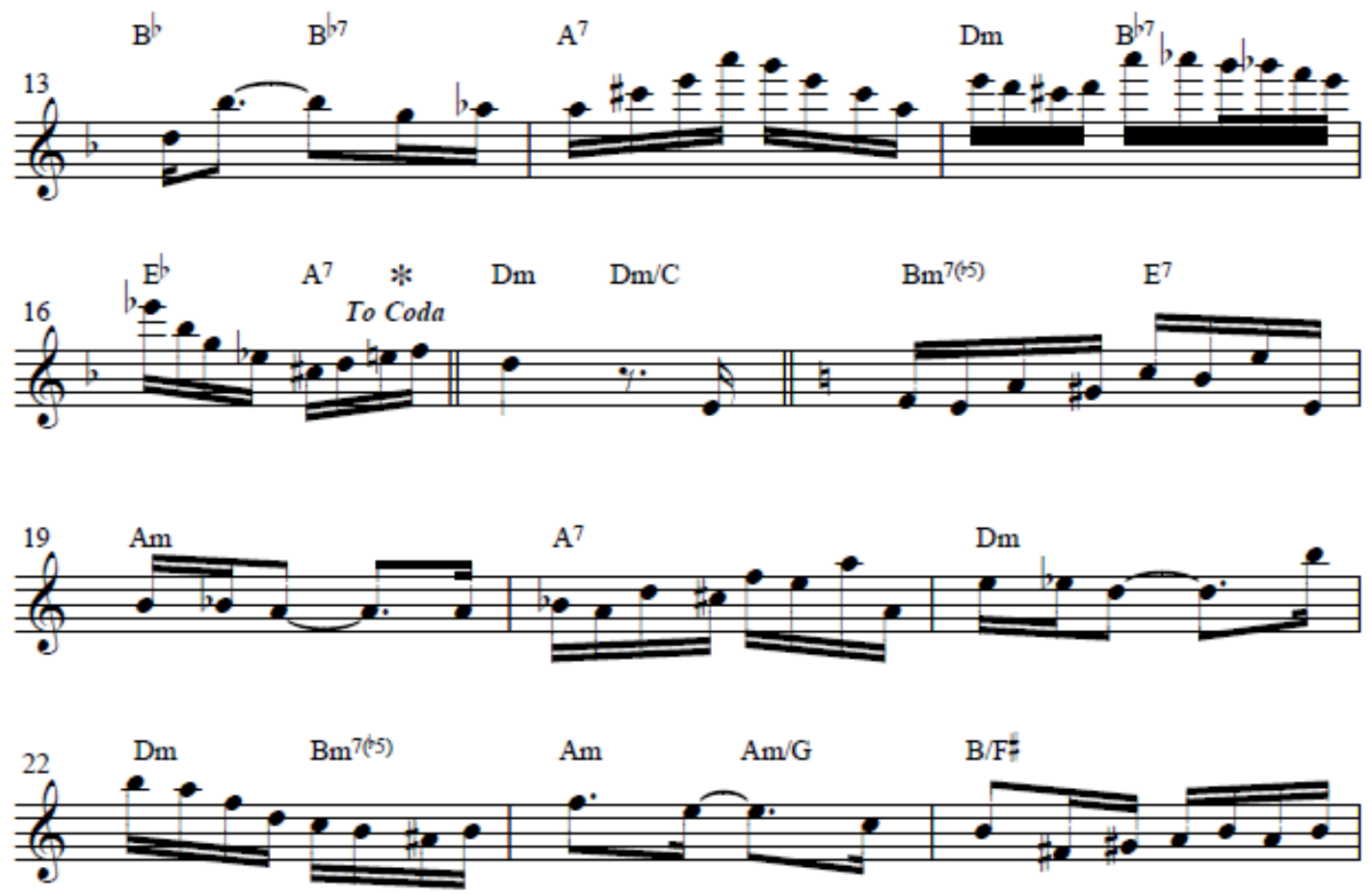

Fonte: Chorando baixinho (Abel Ferreira), transcrição do autor. 
A figura acima ilustra a modulação do I (Dm) para o Vm (Am) na passagem da parte A para a parte B de Chorando Baixinho de Abel Ferreira. No compasso 18, a nova tonalidade é preparada pela cadência II V - Bm7(b5) E7 - chegando à nova tonalidade (Am) no compasso 19.

Portanto, os esquemas harmônicos e os trechos musicais apresentados expõem os principais elementos da Harmonia que um violonista precisa dominar: as principais formações e digitações de acordes e os principais caminhos harmônicos, que o auxiliem a intuir a Harmonia. Optei por apresentar uma rápida visualização desses elementos para destacar os conhecimentos e as habilidades harmônicas importantes para o V6.

Naturalmente, tanto a Harmonia quanto a própria Teoria das Árvores Harmônicas do professor Alencar 7 Cordas são temas muito amplos (provavelmente infinitos), que extrapolam as intenções desta pesquisa, motivo que me levou a apresentar uma visão rápida sobre o assunto, com foco na maior ocorrência de encadeamentos harmônicos no Choro. Acredito que, embora importante, este tópico seja uma exposição preliminar sobre o tema, que poderá ser ampliado em outros trabalhos.

5.2 LEVADAS - “Quando a mão direita vai bem é sinal de progresso”27

Na segunda metade do século XVIII, um grande contingente de negros migrou da Bahia para o Rio de Janeiro e se fixou na região das docas, Cidade Nova e Morro da Conceição. Esses negros da Bahia trouxeram um ritmo sincopado que, somado aos ritmos e danças populares da Europa, como a schottish, a polca, a mazurca e a valsa, deram origem ao samba carnavalesco com seus figurinos típicos e característicos. Durante décadas, em toda celebração ou ritual, os negros brasileiros se serviram das tradições africanas do ritmo e da dança para extravasar seus sentimentos de alegria e religiosidade (...) (PEREIRA, 2007, p.7).

Como descrito pelo violonista Marco Pereira, acima, a rítmica africana influenciou de modo irreversível a música brasileira. Tal influência é também observada por D’Ávila (2009, p.3):

Paralelamente ao processo de erudição que já se desenrolava nos idos do século XVIII, uma outra parcela bem mais vultosa de negros bantos, jêjes e nagôs, percussionistas, fazia penetrar instintivamente suas raízes na comunidade musical brasileira, possibilitando com que, através dos séculos, fosse sendo formada uma identidade musical que seria futuramente e

${ }^{27}$ CIDINHO 7 CORDAS, 2015, Entrevista, p.9. 
internacionalmente reconhecida pela dicotomia Samba-Bossa Nova (...) que colocam o Brasil, na atualidade, como um país dos mais conceituados do mundo em riqueza musical, instrumental e rítmico-sonora.

De fato, vão muito além do Samba e da Bossa Nova (embora estes sejam os estilos brasileiros mais conhecidos no exterior), as manifestações estilísticas brasileiras - e suas inúmeras variantes - em que o quesito Ritmo normalmente é fator determinante. À guisa de ilustração podem ser citados: Baião, Boi, Calango, Capoeira, Cateretê, Cavalo-marinho, Chamamé, Choro, Chula, Ciranda, Côco, Congada, Maracatu, Frevo, Galope, Ijexá, Jongo, Marcha, Maxixe, Maculelê, Tambor de Crioula, Toada, Xaxado e Xote, dentre, certamente, muitos outros.

Como consequência desta diversidade rítmica, uma das características mais importantes do Violão Brasileiro, na maioria dos estilos, tornou-se, ao longo do tempo, a performance da mão direita (no caso dos destros), frequentemente, tratada como "Levada” e principal responsável pelo desenrolar rítmico. Como resultado musical, os violonistas desenvolveram uma enorme variedade de formas em realizar o trabalho com a mão direita.

Naturalmente, no Choro não haveria de ser diferente. Nas falas dos entrevistados, a mão direita tem um papel central para a realização de uma boa condução rítmico-harmônica, como observado no depoimento de Cidinho 7 Cordas (2015, E., p.12): "Não é só no Choro, mas em todos os gêneros musicais, a mão direita é a alma do negócio”.

Como observado anteriormente, a origem do Choro esteve intimamente ligada, inclusive ritmicamente, às contribuições do Lundu e da Polca. O Lundu ${ }^{28}$ como dança, por vezes tratado como a primeira dança brasileira e, portanto, ancestral do Maxixe, é considerado uma expressão cultural afro-brasileira, caracterizada pela roda coletiva, pelo bailado de par solto, pela umbigada e pelos movimentos sensuais dos quadris. Importante notar a importância da dança no estilo musical e a influência recíproca em que ambos se contaminam: “Atrás do gesto, do movimento, vem a música, aliás, seguindo uma tradição africana, onde não só os músicos estimulam à dança, mas também os bailarinos transformam a música, através de um diálogo improvisado”. (LEME, 2006, p. 38-39). Nesse sentido, Sève aponta que:

\footnotetext{
${ }^{28}$ Lundu - ritmo profano originário do batuque que no século XVIII passou a acompanhar modinhas e a manifestar-se fracionado em obras eruditas (ex.: Missa de Santa Cecília - Padre Maurício N. Garcia). Desse modo foi identificado como dramático-religioso, reassumindo, no século seguinte, seu caráter profano. É acompanhado de palmas e, mais tarde, de viola (influência portuguesa), substituindo a Fofa. Ritmo básico que influenciou vários outros ritmos brasileiros: baião, lambada, bossa-nova, o básico do Olodum, afoxé (Ijexá), etc (D’ÀVILA, 2009, p.20).
} 
O fraseado europeu que deu origem ao choro foi se modificando à medida que a música se expunha à dança, sempre se adaptando aos novos gingados do brasileiro. E assim a polca foi se transformando em maxixe, o maxixe em samba, etc. Na música popular, principalmente quando associada à dança, permite-se grande liberdade de interpretação. Com relação às suas partituras, pode-se dizer que "o que se escreve nem sempre é o que se toca”. (SÈVE, 1999, p. 11).

A próxima figura é uma representação do Lundu feita pelo pintor alemão Rugendas, que viajou pelo Brasil de 1822 à 1825:

Figura 34 - Ambiente do Brasil colônia, a dança do lundu.

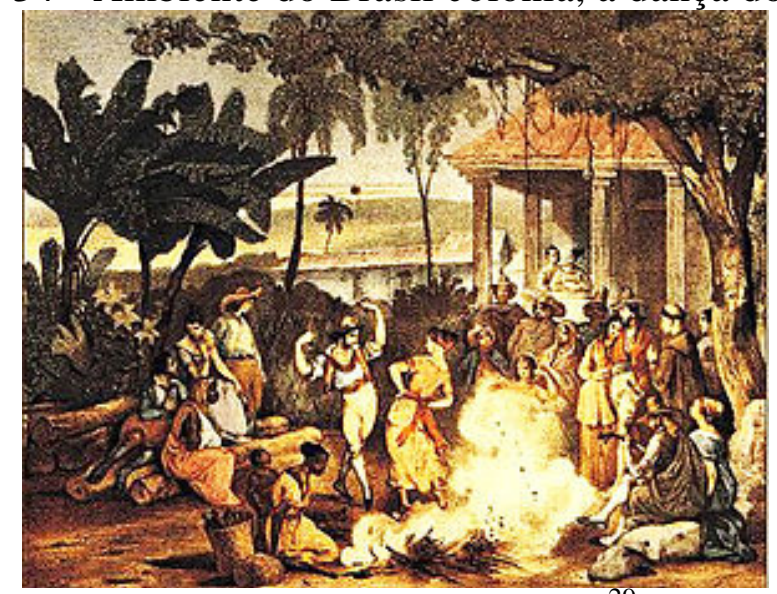

Fonte: Rugendas, O Lundu ${ }^{29}$

No aspecto musical, o Lundu esteve marcado pela presença de células rítmicas importantes para o desenvolvimento da identidade musical nacional, sobretudo a síncope. A figura abaixo ilustra um possível acompanhamento para o Lundu:

Figura 35 - Acompanhamento de Lundu.

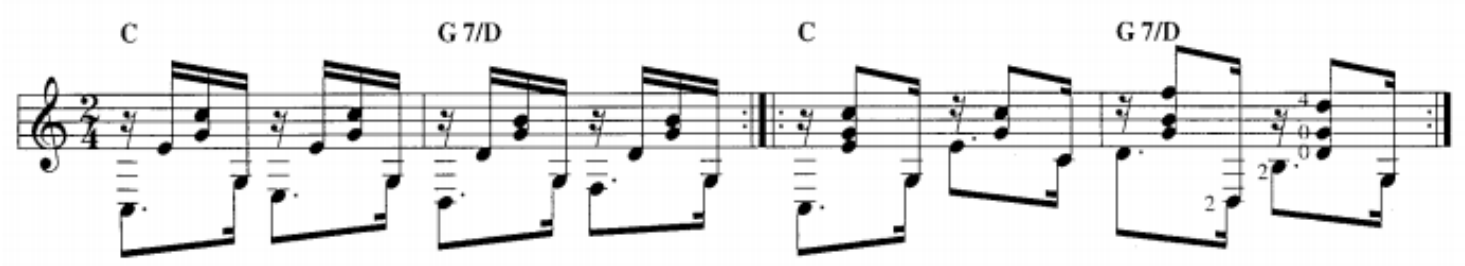

Fonte: BRAGA, 2002, p.16.

${ }^{29}$ RUGENDAS. O Lundu. Disponível em <https://pt.wikipedia.org/wiki/Lundu>. Acesso em: junho de 2016. 
Na figura acima é possível observar a forte presença da síncope nos compassos 3 e 4 . Mário de Andrade sugeriu a nacionalidade brasileira da síncope. Assim ele caracterizou a sua origem e sua importância:

(...) provavelmente a síncope que nos encarregamos de desenvolver ao contato da pererequice rítmica do africano... Também tomou parte vasta na formação do canto popular brasileiro. Foi certamente ao contato dele que a nossa rítmica alcançou a variedade que tem, uma das nossas riquezas musicais. (ANDRADE, 1977, p.185-186).

Conhecida dos europeus, embora tratada como uma espécie de exceção musical, a síncope (ou síncopa) é elevada à condição de figura cotidiana e estruturante nessa nova música:

É uma alteração rítmica, um prolongamento do som do tempo fraco para o tempo forte. A síncopa já aparece no lundu e estende-se aos diversos gêneros musicais brasileiros, definindo-se como uma característica rítmica desta música. Os europeus já conheciam a síncopa, que foi trazida pelos portugueses, portanto não é puramente africana. E como diz Muniz Sodré (1998, p.25): "se na Europa ela era mais frequente na melodia, na África sua incidência básica era rítmica. A síncopa brasileira é rítmico-melódica”. (MARCÍLIO, 2009, p.59).

O mesmo Mário de Andrade, que afirmou ser a síncope no primeiro tempo do compasso de dois “a característica mais positiva da rítmica brasileira” (apud SANDRONI, 2001, p. 21), afirmava também que "muitos movimentos chamados de sincopados não são síncopa. São polirritmia ou são ritmos livres de quem aceita as determinações fisiológicas de arsis e tesis porém ignora (ou infringe propositalmente) a doutrina dinâmica falsa do compasso" (ANDRADE, apud SÈVE, 2014, p.1150).

O músico e pesquisador Mário Sève (2014) aponta para o fato da síncope, assim como o compasso (sistematizado no período barroco), não ser um conceito universal. Apontando para os estudos de Jones, Arom, Kubik, Kolinsky e Sandroni, ele afirma que a síncope "não existe, como a conhecemos, na rítmica africana, embora costumeiramente represente o que há de africano na música ocidental - no caso brasileiro, do lundu ao samba, o irregular da síncope muitas vezes significa a regra, o mais comum, o característico”. (SÈVE, 2014, p.1150).

Para Braga, o Choro incorpora os ritmos e o jeito de tocar das danças de origem europeia. Em suas palavras: 
a manifestação primordial, formativa, daquilo que redundaria na primeira expressão eminentemente brasileira em termos de música - o Choro passou por um processo característico, à base de violão, flauta e cavaquinho, de se tocarem danças de procedências europeias. É assim que polcas, habaneras (provenientes de Cuba e Haiti), scottishes, mazurcas, valsas, ligados à antigas manifestações da modinha e do lundu, este de origem africana, remeterão diretamente ao Choro brasileiro. Participar de uma roda de Choro é encontrar um vasto repertório dessas danças nacionalizadas (...). (BRAGA, 2002, p.14).

Portanto, não seria exagero afirmar que o material musical que deu origem ao Choro está intimamente ligado aos enfrentamentos culturais relativos aos encontros musicais entre as danças europeias e as danças africanas, como será apresentado a seguir.

\subsubsection{As danças europeias e as danças africanas: a origem do choro}

Muitos pesquisadores admitem, portanto, a genealogia do Choro como o resultado, sobretudo, do cruzamento estre aspectos musicais europeus e africanos. Tal cruzamento é frequentemente visto como as articulações entre as melodias europeias e os ritmos africanos. Em relação a tais articulações culturais ${ }^{30}$, é preciso ter em mente a constituição da Polca tradicional, originária da Boêmia, pois esta parece ter sido a principal influência europeia na constituição do Choro. Segundo Marcílio (2009, p.71) a dança, possuidora de fórmula de compasso binário 2/4, “importada pela elite, foi levada primeiramente aos salões, para depois ser dançada pelas camadas pobres da sociedade, onde na sua maioria viviam negros ou descendentes destes”. Segundo ela:

Kiefer (1990, p.16) ao falar da polca europeia, aquela que primeiro chegou ao Brasil, explica que o acento vem no contratempo, na segunda colcheia de cada tempo, porém sem notas pontuadas ou síncopes internas, podendo haver variações neste esquema: Com o passar do tempo, a polca foi se desenvolvendo no Brasil, e foram aparecendo algumas variações na divisão rítmica do acompanhamento. Um destes motivos rítmicos é formado por um grupo de uma colcheia somado a duas semicolcheias no primeiro tempo do compasso, e duas colcheias no segundo tempo, podendo sofrer pequenas variações: As polcas brasileiras geralmente fazem grande uso de síncopas e notas pontuadas (MARCÍLIO, 2009, p.73).

\footnotetext{
${ }^{30}$ O diálogo entre Europa e Brasil está presente também obra para violão solo de Villa-Lobos. A Suíte Popular Brasileira, onde o compositor associa o Choro às danças europeias, é composta por: Mazurka-Choro, SchottischChoro, Valsa-Choro, Gavota-Choro e Chorinho.
} 
Portanto, partindo do seu formato original, a Polca pode ter sido assimilada pela cultura musical brasileira - via danças africanas - e sofrido alterações que a diferenciariam de sua versão “original”.

Figura 36 - Polca europeia tradicional.

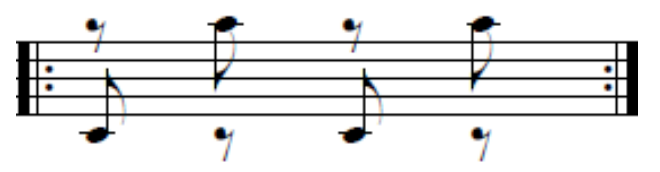

Fonte: transcrição do autor.

Segundo o músico e pesquisador Maurício Carrilho (2007), a partir de tais alterações chegou-se a aquilo que ele chamou de Polca Brasileira.

Figura 37 - Polca brasileira.

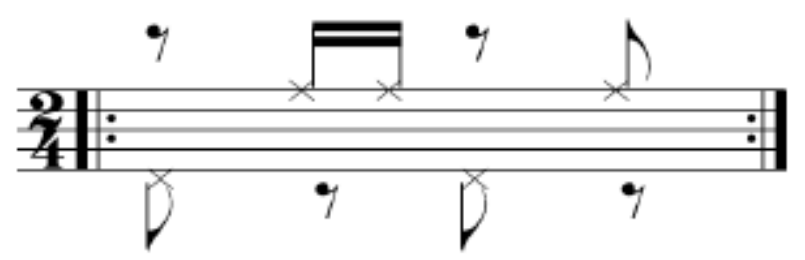

Fonte: CARRILHO (apud BITTAR, 2011).

Nos exemplos a seguir, Carrilho apresenta aquilo que chamou de variações da Polca brasileira:

Figura 38 - Variantes da Polca brasileira. 


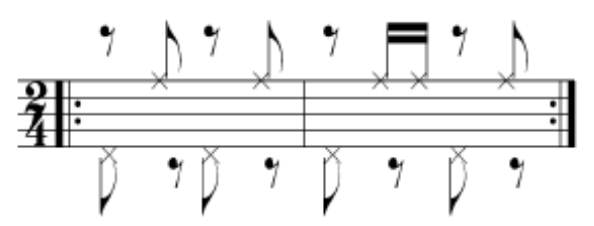

Polca - Variação 1 - "A Vida é Um Buraco" (Pixinguinha)

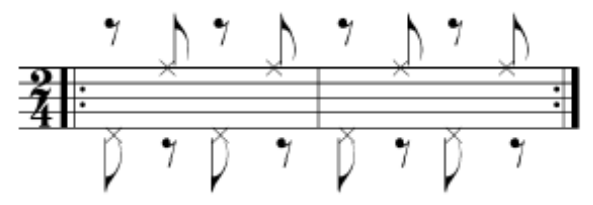

Polca - Variação 2 - "Dança de Urso" (Candinho)

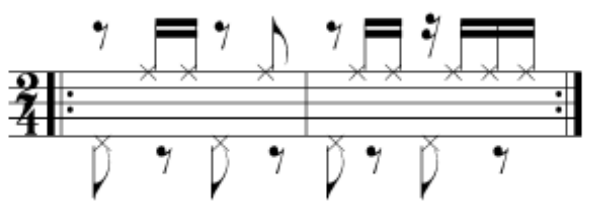

Polca - Variação 3 - "Coralina" (Albertino Pimentel)

Fonte: CARRILHO (apud BITTAR, 2011).

A figura abaixo, editada em 1914, representa uma típica Polca Brasileira, com a presença constante da célula rítmica com colcheia +2 semicolcheias no primeiro tempo e 2 colcheias no segundo tempo, tal como apresentada no primeiro exemplo da figura acima. Em forma de Polca-Choro, Apanhei-te cavaquinho é frequentemente executada no repertório atual dos chorões.

Figura 39 - Célula rítmica da Polca Brasileira. 


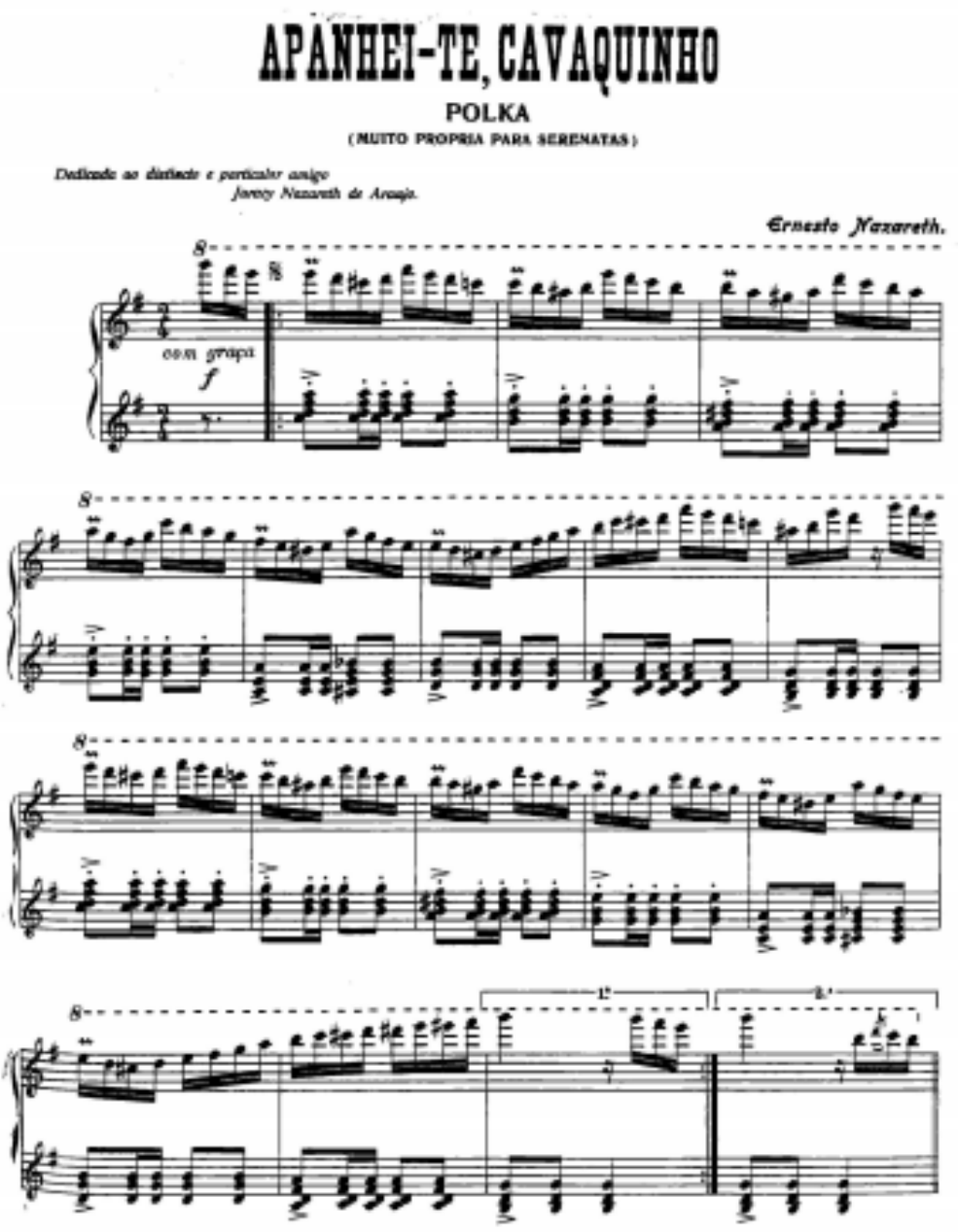

Fonte: Ernesto Nazareth. Apanhei-te cavaquinho, 1914.

De acordo com Sève, aquilo que inicialmente foi apenas uma forma abrasileirada de tocar as polcas se transformaria adiante em um gênero: "De um estilo de tocar polcas, no princípio, a um gênero musical, posteriormente, o Choro” (SÈVE. 2014, p.1149). Essa teoria é compartilhada por Marcílio, ao descrever a trajetória da Polca no Brasil, iniciada pelo piano elitizado e chegando aos grupos de músicos e dançarinos populares:

No princípio era tocada nos salões da alta sociedade e executada preferencialmente ao piano. Depois, foi se popularizando e tocada por grupos de chorões, que, com um certo jeitinho, ao tentar acompanhar os passos e os remelexos do corpo dos bailarinos através da incorporação de novas figuras rítmicas cada vez mais sincopadas, modificavam os acentos da melodia e do acompanhamento, criando um novo estilo musical. (MARCÍLIO, 2009, p.71).

As variações e acentuações rítmicas podem ser observadas na partitura a seguir, editada em 1926. Nela é possível perceber a presença constante da célula rítmica da Polca 
Brasileira (figura 39) no acompanhamento. No entanto, a peça é classificada como um Choro Brasileiro, indicando a proximidade entre os estilos.

Figura 40 - O Choro e a Polca Brasileira.

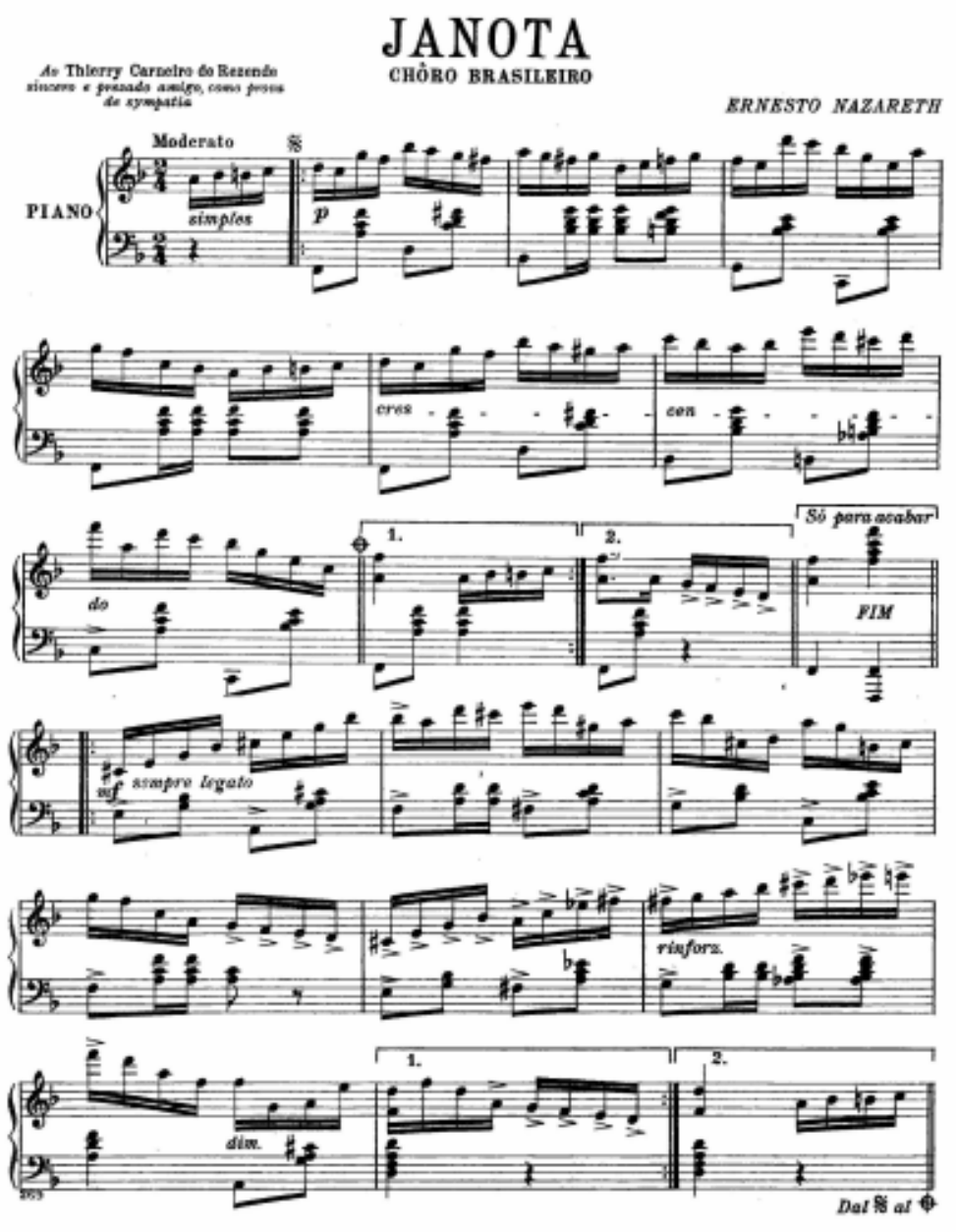

Fonte: Ernesto Nazareth, Janota, 1926.

Neste processo de miscigenações, provavelmente por influência do Lundu (e também da Habanera), a Polca passou a incorporar as síncopes, aproximando-se mais ainda daquilo que futuramente serviria de material rítmico-melódico ao Choro e ao Maxixe. Portanto, parece razoável admitir uma origem do Choro a partir das transformações que o Lundu, principalmente, imprimiu à Polca. Segundo Sève, é desse encontro rítmico-melódico que nasce o Choro.

Da “mágica” fusão da polca com o lundu - onde aspectos melódicos e rítmicos dialogaram entre conflitos e semelhanças - nasceu, provavelmente, o fraseado do Choro. Uma melodia de origem europeia (do clássico e do 
barroco) teve de "inventar" uma forma de articulação musical para se adaptar a padrões rítmicos de origem africana (da cultura de negros escravos bantus) que aqui existiam manifestados pelo batuque e pela dança. (SÈVE, 2016, p.1150).

No entanto, tais fusões nem sempre foram bem aceitas. Apesar da forte presença do Maxixe no universo composicional da época, a palavra "Polca” tratou de manter as aparências na sociedade elitizada, uma vez que o consumo declarado de Maxixe poderia soar “deselegante”. Este episódio reforça a ideia de sincretismo apresentada anteriormente na secção sobre a constituição histórica do Choro (ASPECTOS HISTÓRICOS), em que foram discutidas algumas formas de como se deram as articulações culturais (CASTAGNA, 2010) na música e na sociedade brasileira e como o sincretismo se revelou como estratégia de sobrevivência. Marcílio (2009, p. 72) aponta que: “como era bem aceita pelas elites e sendo música europeia, alguns gêneros, como o maxixe, se prevaleceram dela para sua designação. Por este motivo, encontraram-se muitas vezes partituras intituladas polcas, que são, na verdade, outros gêneros”.

Portanto, o Maxixe esteve, embora muitas vezes ausente nominalmente, musicalmente entremeado nesse processo. Sua presença poderia ser mascarada ainda pela composição de gêneros híbridos, atenuando sua origem popular:

(...) outra razão para compor gêneros híbridos, que está ligada diretamente ao gênero maxixe, era a possibilidade de os compositores ligarem os gêneros de origem popular aos de origem europeia, sendo um outro meio de venderem suas partituras. (MARCÍLIO, 2009, p. 72)

Não bastassem tais estratégias, os compositores por vezes recorreram à criação de condinomes $^{31}$, como forma de não misturar sua carreira "séria” com sua atuação na música popular. Os compositores de piano frequentemente lançaram mão desse expediente, ao mesmo tempo que popularizavam a música popular: O piano teve importância capital no desenvolvimento do maxixe, pois num período anterior ao gramofone e ao rádio, a forma mais fácil de ouvir música nos ambientes pequenos, como nas salas de espera dos cinemas e dos teatros, e nas festas familiares era através deste instrumento. (LEME, 2006, p. 50).

31 Elizabeth Travassos (2000, p.10), ao escrever sobre o pianista Francisco Mignone, aponta que: “da sua familiaridade com ambientes da música popular paulistana do início do século e da necessidade de ganhar a vida nasceu o Chico Bororó, pseudônimo com o qual assinava Maxixes, Tangos e Valsas que antecedem 1917”. De forma parecida, muitos outros compositores, como Ernesto Nazareth e Guerra Peixe, precisaram se proteger com condinomes. Segundo Travassos (2000, p.12), a associação com a música popular "poderia fechar-lhes as portas no meio restrito e exigente da música de concerto, com poder para desqualificar produções e produtores identificados como populares”. 
Convém destacar que a síncope assimilada pela Polca faz parte do Maxixe, tanto em sua estrutura melódica quanto em sua estrutura de acompanhamento.

Figura 41 - Célula rítmica do Maxixe.

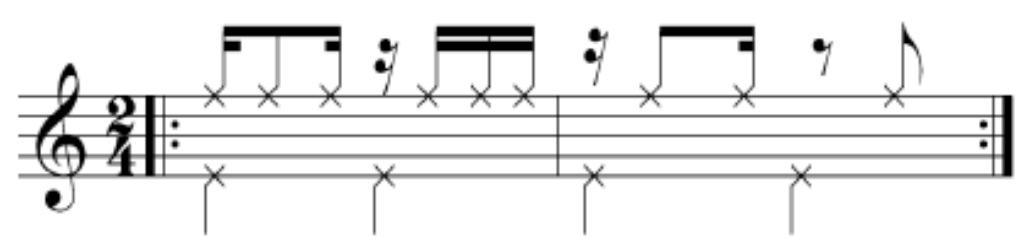

Fonte: CARRILHO (apud BITTAR, 2011).

O pianista Ernesto Nazareth, cuja importância na genealogia do Choro já foi discutida anteriormente, utilizou frequentemente o padrão do Maxixe (especificamente aquele apresentado no segundo compasso da figura acima) no acompanhamento da mão esquerda em sua obra. No entanto, quando apresentada como Maxixe, a peça era assinada por Renaud, um condinome utilizado por Nazareth:

Figura 42 - O Maxixe no piano.
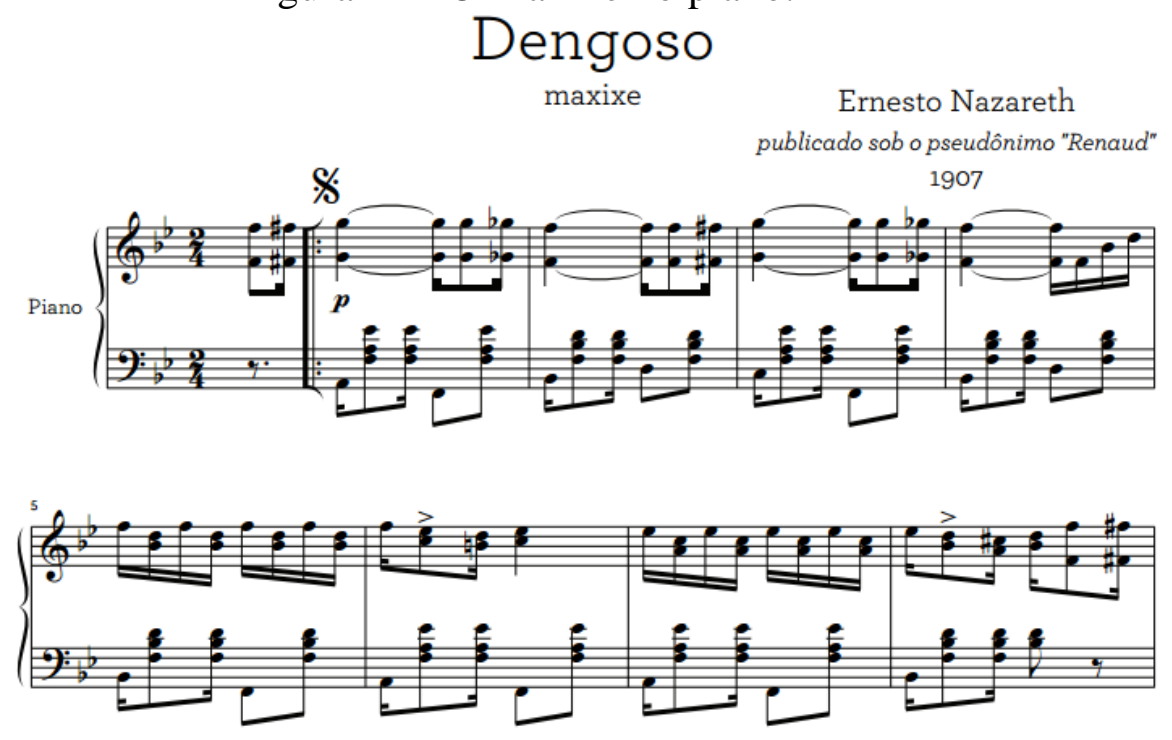

Fonte: Ernesto Nazareth, Dengoso, 1907.

Outra estratégia utilizada por Nazareth foi a de cunhar o termo "Tango Brasileiro" em suas partituras de Maxixe estilizado. Tinhorão (apud SÈVE, 2014, p.1052) confirma esse recurso do pianista: O primeiro compositor a estilizar o ritmo do maxixe, sintetizado pelos conjuntos de Choro a partir da polca e do lundu, foi o pianista Ernesto Nazareth em uma versão semierudita, para música de salão, que chamou de “tango brasileiro”. 
A denominação “Tango Brasileiro” ou simplesmente “Tango” está presente em grande parte da obra de Ernesto Nazareth, como ilustram os exemplos a seguir:

Figura 43 - Célula rítmica do Maxixe presente no acompanhamento do Tango Brasileiro. Dedicado à bela Orquestra da Brahma dirigida pelo Maestro Russo.

\section{Escorregando}
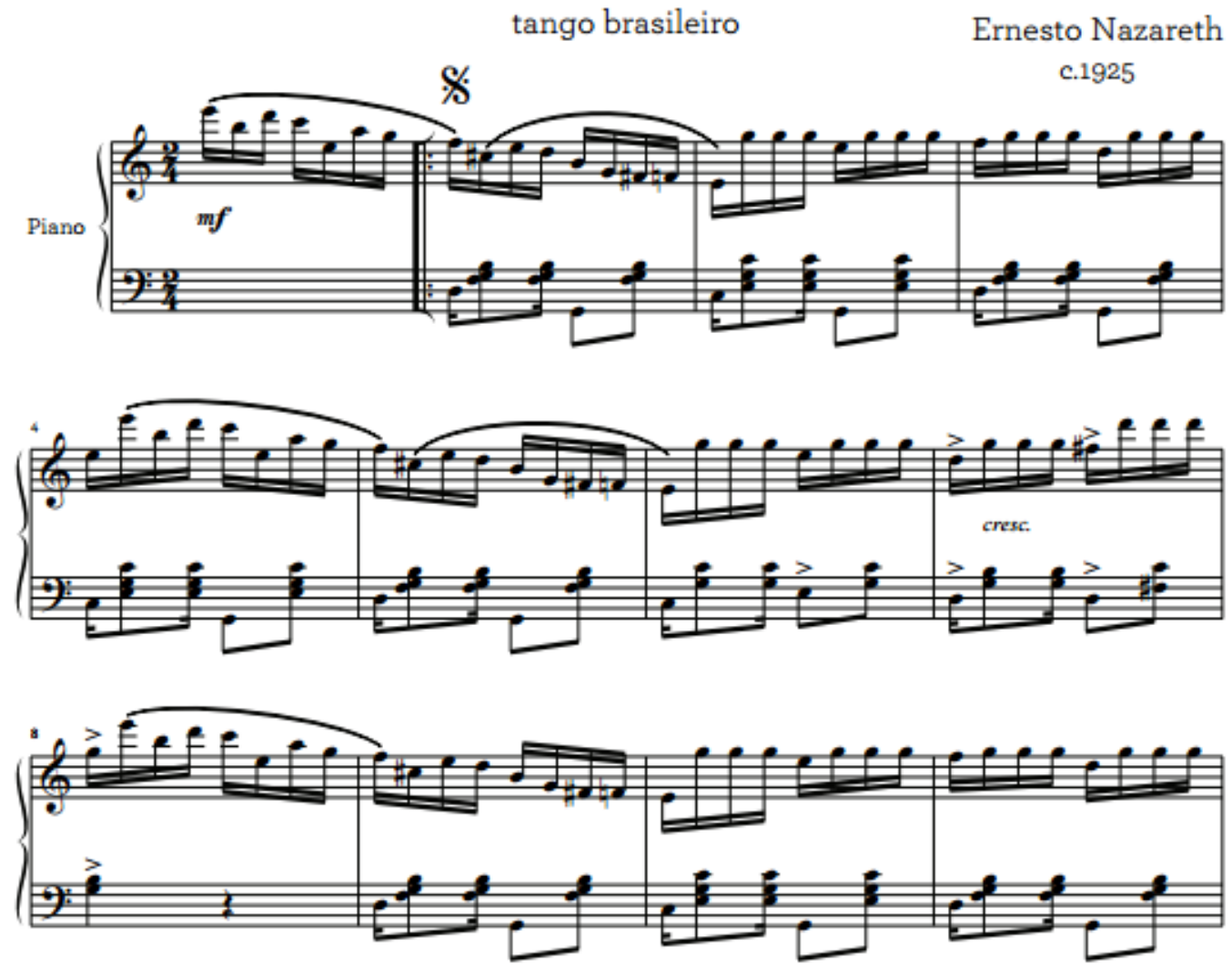

Fonte: Ernesto Nazareth, Escorregando, 1923.

Figura 44 - Célula rítmica do Maxixe presente no acompanhamento do Tango - exemplo 2. 

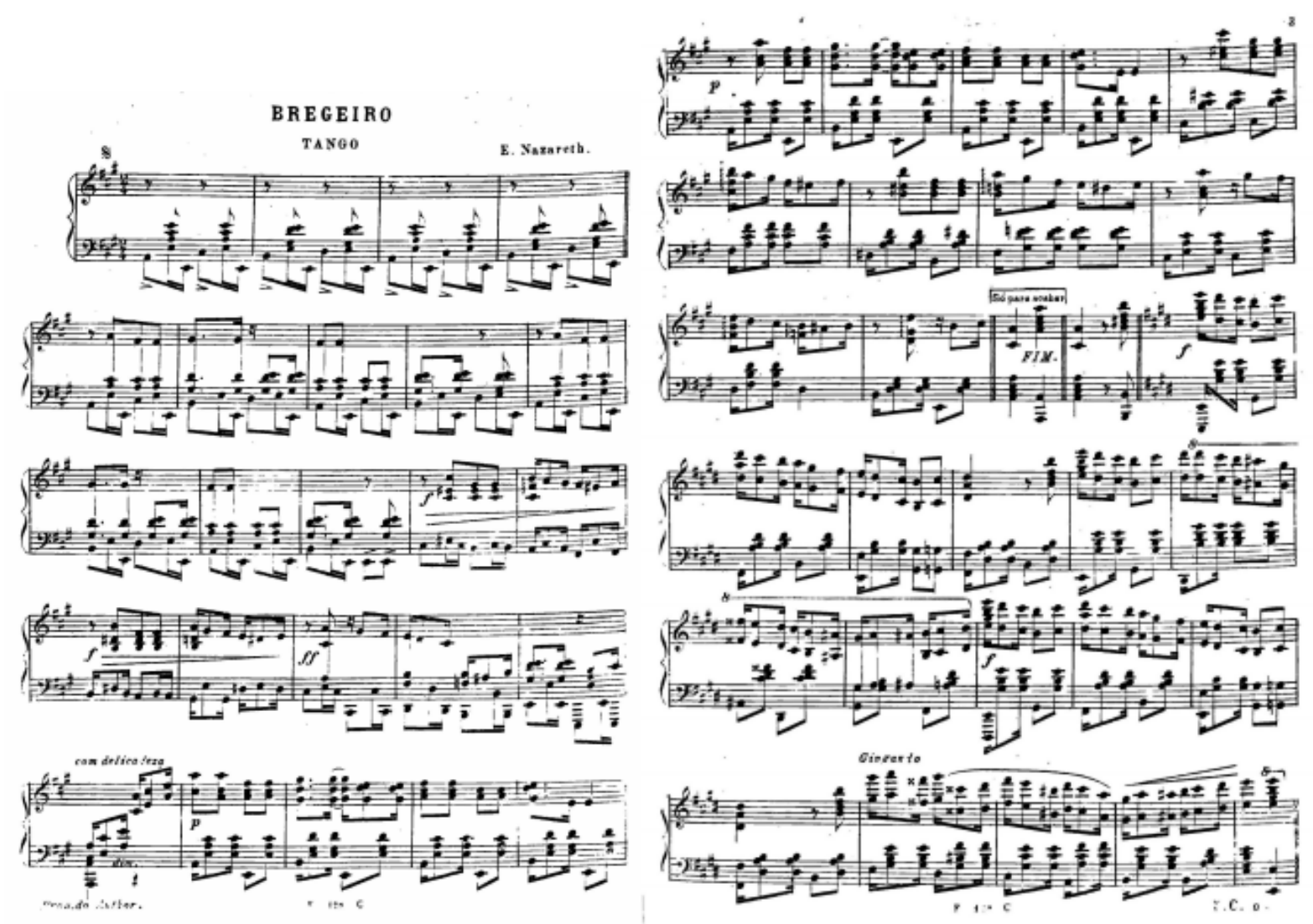

Fonte: Ernesto Nazareth, Brejeiro, 1893.

As figuras 43 e 44, denominadas Tango Brasileiro e Tango, respectivamente, ilustram a presença da célula rítmica do Maxixe apresentada na figura 41 (segundo compasso) como acompanhamento da mão esquerda em 2 dos mais conhecidos Tangos Brasileiros de Nazareth: Escorregando e Brejeiro. Em Escorregando, a figura aparece já no segundo compasso e permanece presente praticamente por toda a peça. Em Brejeiro, tal figura se consolida a partir do compasso 21. Antes disso, é possível perceber, no acompanhamento, um desenho rítmico próximo ao da Polca Brasileira.

Ainda sobre o Maxixe, Marcílio aponta que Mário de Andrade, em uma conferência sobre o próprio Ernesto Nazareth em 1926, disse que o gênero é oriundo da Habanera e da polca:

(...) se originou da fusão da habanera, pela rítmica e da polca pela andadura, com adaptação da síncope afro-lusitana. (...) há de se afirmar que do lundu o maxixe herdou sua malícia e sua sensualidade. Depois, incluir o ritmo da habanera que vai aparecer frequentemente no seu acompanhamento (mesmo que fragmentado), porém em andamento mais rápido. (ANDRADE apud MARCÍLIO, 2009, p.77) 
Portanto, nota-se aqui, também, a presença da Habanera ${ }^{32}$ na formação de gêneros musicais brasileiros. Cazes (1998, p. 36) concorda com tal indicação ao afirmar que “O tango brasileiro é, assim como o maxixe, resultado da fusão das melodias de polca com acompanhamento de habanera estilizada, via lundu”. Braga apresenta da seguinte forma a célula típica da Habanera:

Figura 45 - Célula rítmica da Habanera.

Habanera

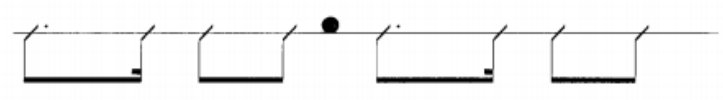

Fonte: BRAGA, 2002, p.15.

Ao lado da célula de Maxixe apresentada anteriormente, a célula da Habanera irá permear grande parte da obra pianística desse período.

Figura 46 - Célula rítmica da Habanera presente no acompanhamento Tango - exemplo1.

32 Segundo Marcílio (2009, p.66)., a Habanera, “primeiramente foi exportada para a Espanha, e de lá difundida pela Europa, para depois chegar ao Brasil, após a segunda metade do século XIX. Foi a precursora de diversas danças de salão latino-americanas. No princípio, era apenas uma canção popular urbana dos portos de Havana, para somente depois se tornar música de salão. No Brasil a habanera não teve a mesma importância para os compositores da música popular como a polca teve, pois não foi muito utilizada por eles, apesar de sua célula principal estar presente em quase todos os ritmos populares da época. (...) A melodia da habanera pode variar, podendo apresentar melodia sincopada; já no acompanhamento a célula citada acima é uma constante”. 

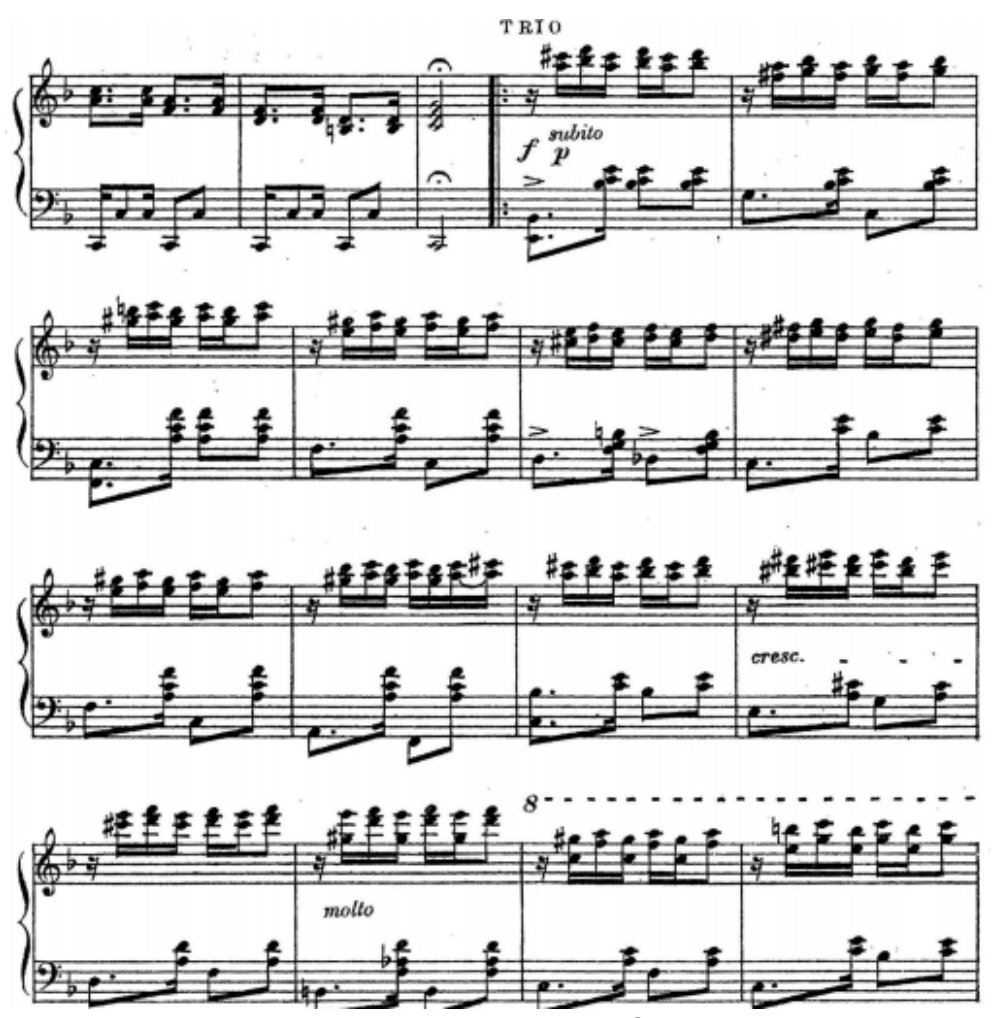

Fonte: Ernesto Nazareth, Atlântico, 1921.

A figura acima ilustra a utilização da célula rítmica da Habanera no acompanhamento (mão esquerda) do Tango Atlântico. Nos dois primeiros compassos, que se tratam do final da parte B, é possível observar a presença da célula do Maxixe. A partir da mudança para a parte C, a célula da Habanera é vigorosamente utilizada, embora o trecho, no contexto musical geral, não soe como tal.

Figura 47 - Célula rítmica da Habanera presente no acompanhamento Tango - exemplo2. 


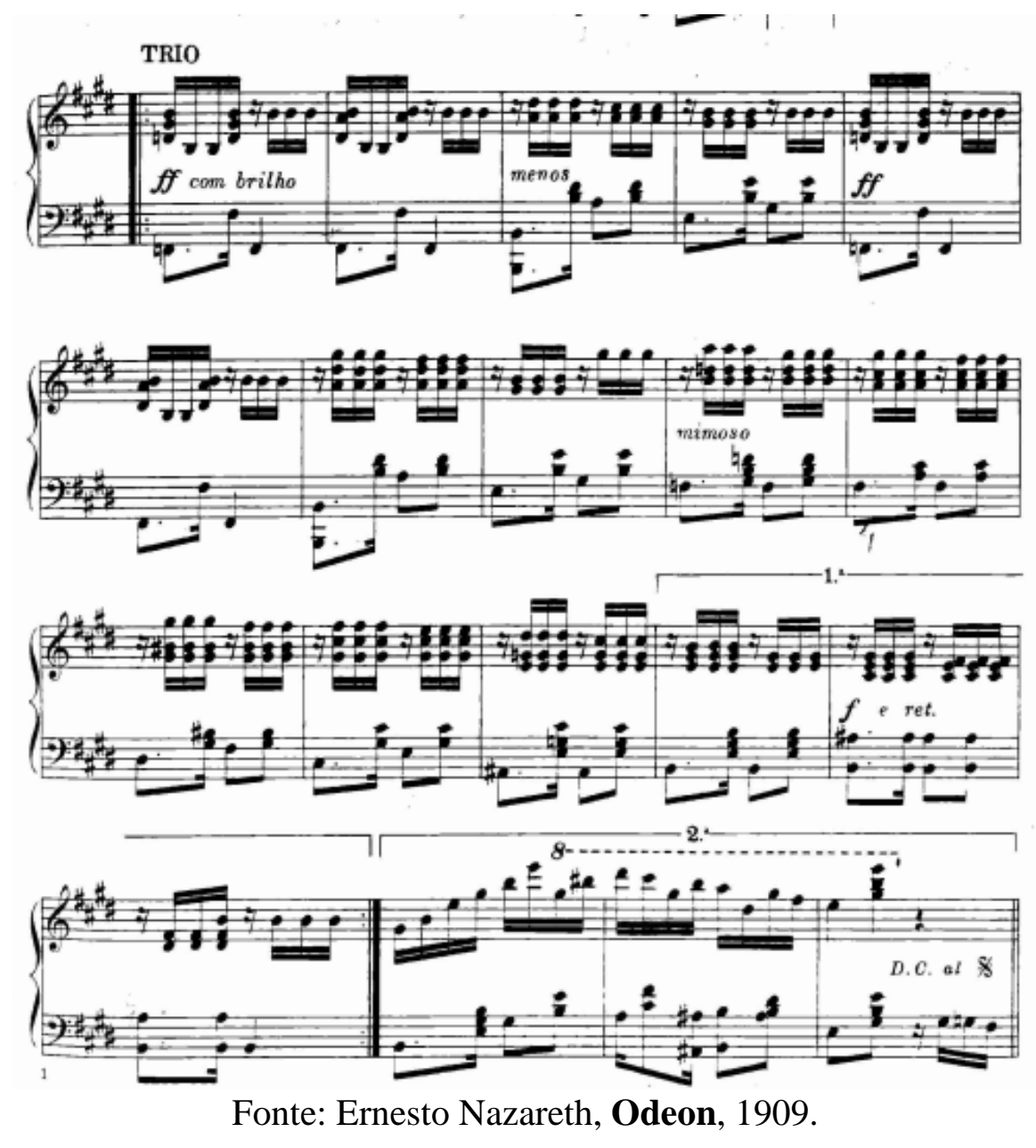

No exemplo acima, extraído da partitura de umas das músicas mais difundidas de Nazareth, o Odeon, é possível observar um “ensaio” de utilização da célula rítmica idêntica à da Habanera nos primeiros compassos da parte C, correspondentes aos primeiros compassos da figura 45. A partir do compasso 7, tal utilização é consolidada e permanece por praticamente todo o trecho.

Nas duas partituras acima, é possível, portanto, observar a presença da célula rítmica da Habanera no acompanhamento dos Tangos de Ernesto Nazareth. Convém destacar que a presença de tais células - tanto a do Maxixe quanta a da Habanera - são importantes diferenças entre tais Tangos (por vezes ditos Tangos Brasileiros) e os Tangos espanhóis/platinos. Marcílio reforça essa diferença, ao caracterizar os tangos brasileiros como uma mistura de Habanera e Maxixe.

É importante citar, que ao estudar os tangos, Augusto (1996, p.37) deixa claro que nele existem mais traços do gênero da habanera do que do tango de origem erudita espanhola, e que algumas variantes em sua denominação estavam frequentes nos tangos do período de 1870 a 1920, como, por 
exemplo, poderiam vir simplesmente como tango, ou tango brasileiro, tango característico, tango carnavalesco, tango de fado e até tanguinho, obtendo estas designações dependendo do caráter derivativo de cada peça. Para ele, a maioria dos tangos tem o ritmo da habanera: (colcheia pontuada somada a semicolcheia para o $1^{\circ}$ tempo, e duas colcheias para o $2^{\circ}$ tempo). Porém, encontra-se também a presença das células rítmicas que aparecem em outros gêneros e principalmente no maxixe. (MARCÍLIO, 2009, p.68)

A figura abaixo, extraída do Maxixe Gaúcho (Corta-Jaca) de Chiquinha Gonzaga, ilustra um tipo de acompanhamento híbrido. Na primeira e na terceira linhas o acompanhamento se constrói sobre a célula do primeiro tempo da Habanera: colcheia pontuada + semicolcheia. Já na segunda e quarta linhas o acompanhamento utilizado é o de Maxixe tradicional: síncope +2 colcheias.

Figura 48 - Acompanhamento Híbrido - Gaúcho de Chiquinha Gonzaga A minha irma Rosinha o Corta-Jaca de CÁ E LÁ

Tango Brasileiro
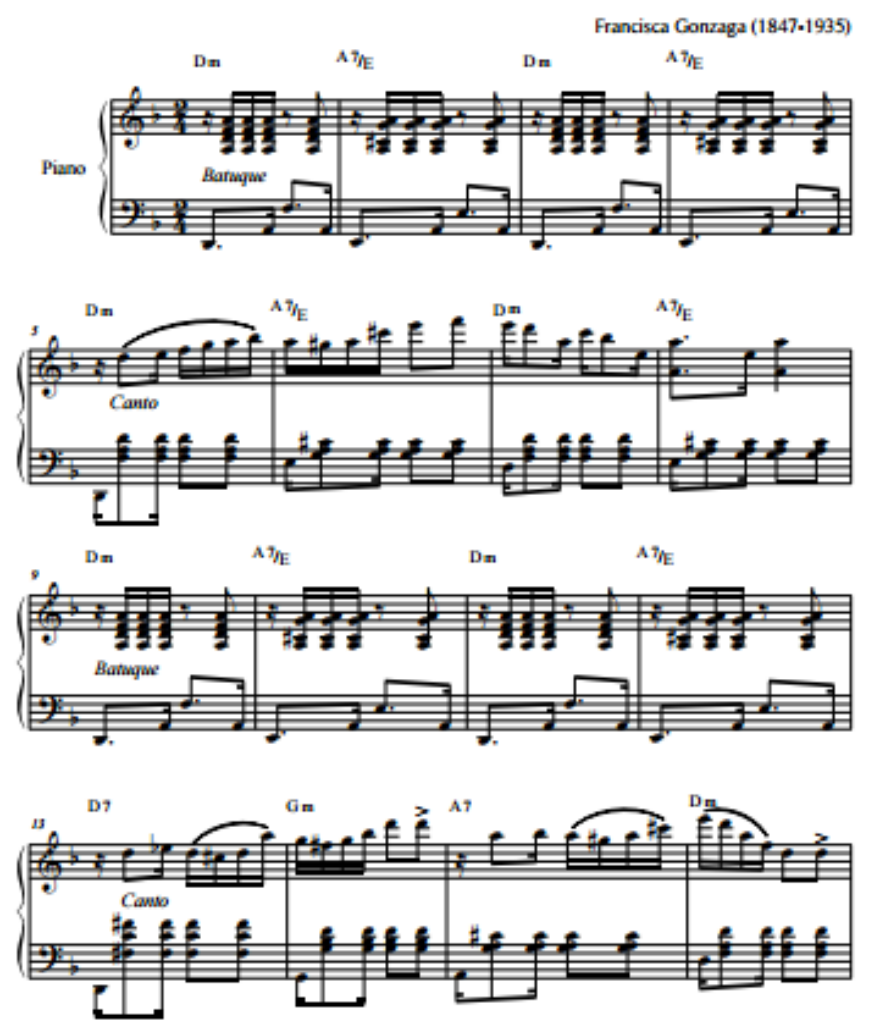

Fonte: Acervo Chiquinha Gonzaga, Gaúcho, 2011. 
É possível, então, imaginar que Lundus, Polcas, Maxixes, Habaneras e Tangos se alimentaram num sincrético caldeirão antropofágico. Tais articulações naturalmente viriam a reverberar no Choro, descendente direto de tais miscigenações.

A Polca-Choro, ou simplesmente Polca, está presente ainda no repertório atual dos chorões. Sua célula rítmica básica é:

Figura 49 - Célula rítmica da Polca Brasileira.

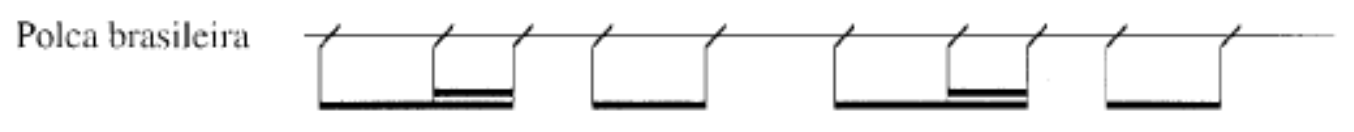

Fonte: BRAGA, 2002, p. 15.

Braga sugere a seguinte possibilidade de acompanhamento para a Polca Só pra Moer de Viriato Figueira:

Figura 50 - Acompanhamento de Polca

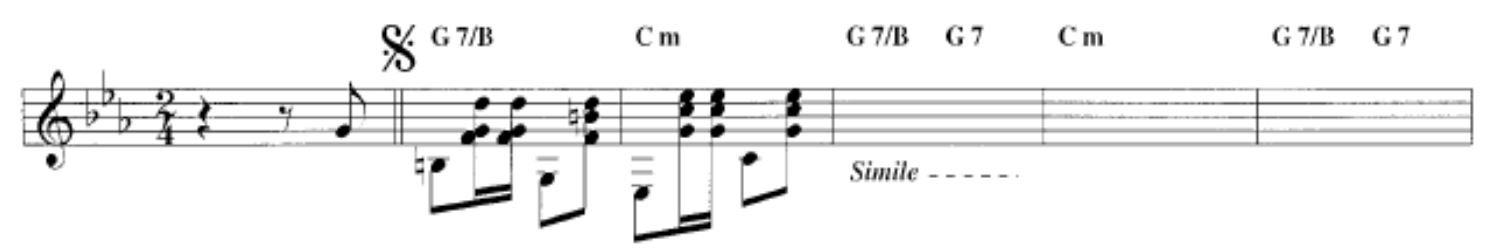

Fonte: BRAGA, 2002, p. 22.

Na partitura acima é possível observar o desenho rítmico da Polca Brasileira: colcheia + 2 semicolcheias no primeiro tempo e 2 colcheias no segundo tempo.

De maneira ainda mais vigorosa que a Polca, o Choro-Maxixe, ou simplesmente Maxixe, está fortemente presente no repertório atual de Choro.

Figura 51 - Célula rítmica do Maxixe.

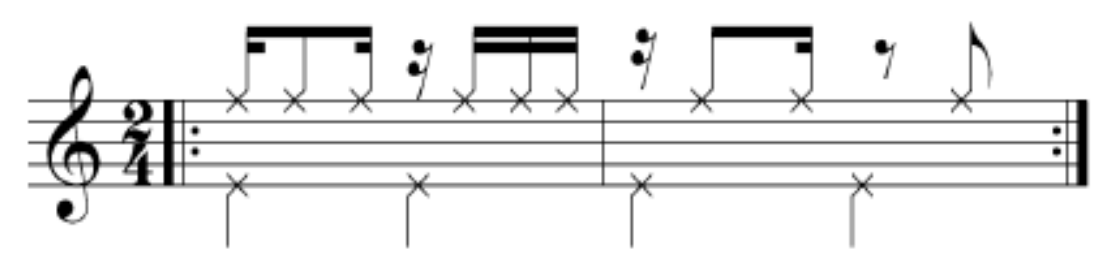

Fonte: CARRILHO (apud BITTAR, 2011). 
Braga apresenta o seguinte acompanhamento para o Maxixe, em que é possível observar a forte presença da célula rítmica presente no compasso 2 da figura acima.

Figura 52 - Acompanhamento de Maxixe.

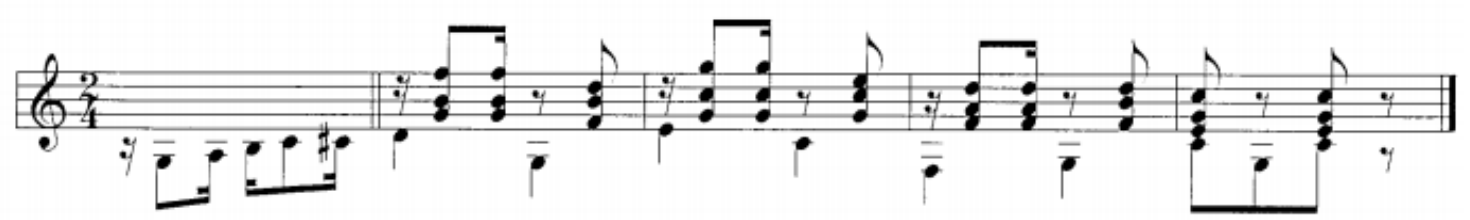

Fonte: BRAGA, 2002, p. 16.

Becker apresenta uma figura específica para o Choro-Maxixe em seu livro sobre Levadas Brasileiras.

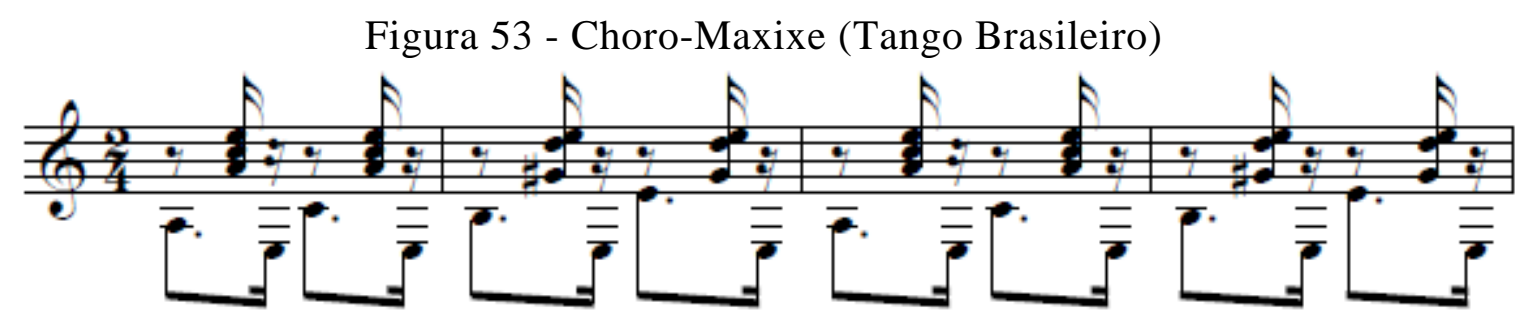

Fonte: BECKER, 2013, p.20 - Corta-Jaca (Chiquinha Gonzaga)

Além disso, a célula rítmica dos baixos é exatamente a mesma da figura 48, utilizada por Chiquinha Gonzaga na condução desta mesma música (figura 48, compasso 9): colcheia pontuada + semicolcheia, provavelmente extraída da Habanera.

A célula de acompanhamento acima apresentada é também utilizada por Ernesto Nazareth em trechos do Tango Brasileiro “Odeon”:

Figura 54 - A levada de Tango Brasileiro 


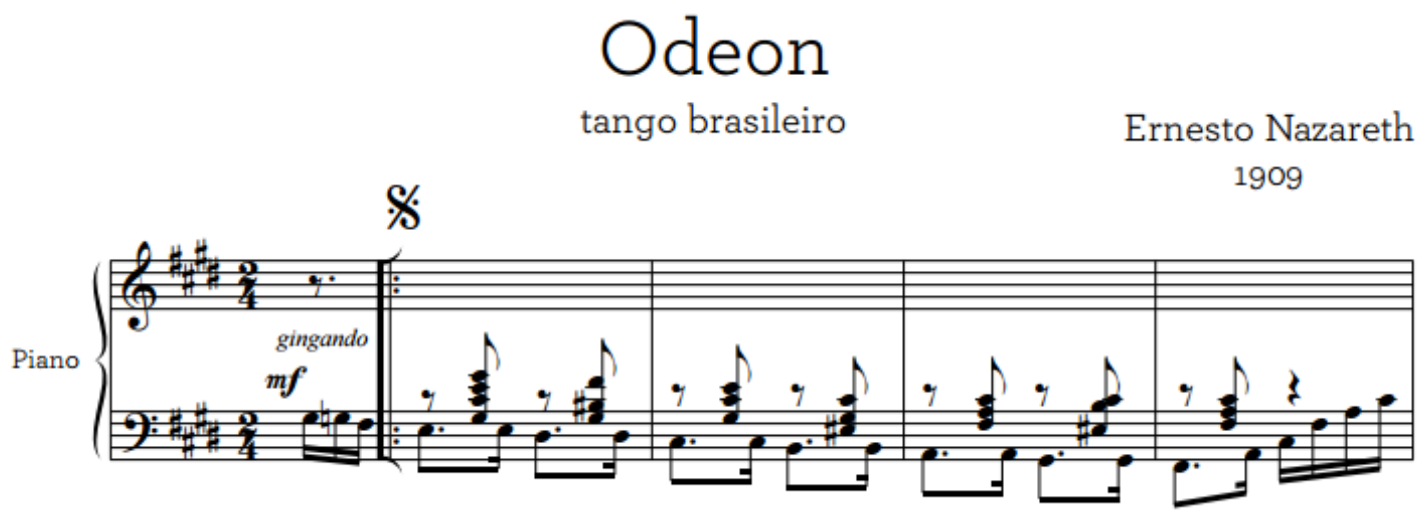

Fonte: Ernesto Nazareth, Odeon, 1909.

O exemplo abaixo é igualmente tratado como um Choro-Maxixe, porém sua configuração rítmica é um pouco diferente do exemplo anterior:

Figura 55 - O Choro-Maxixe no Violão.

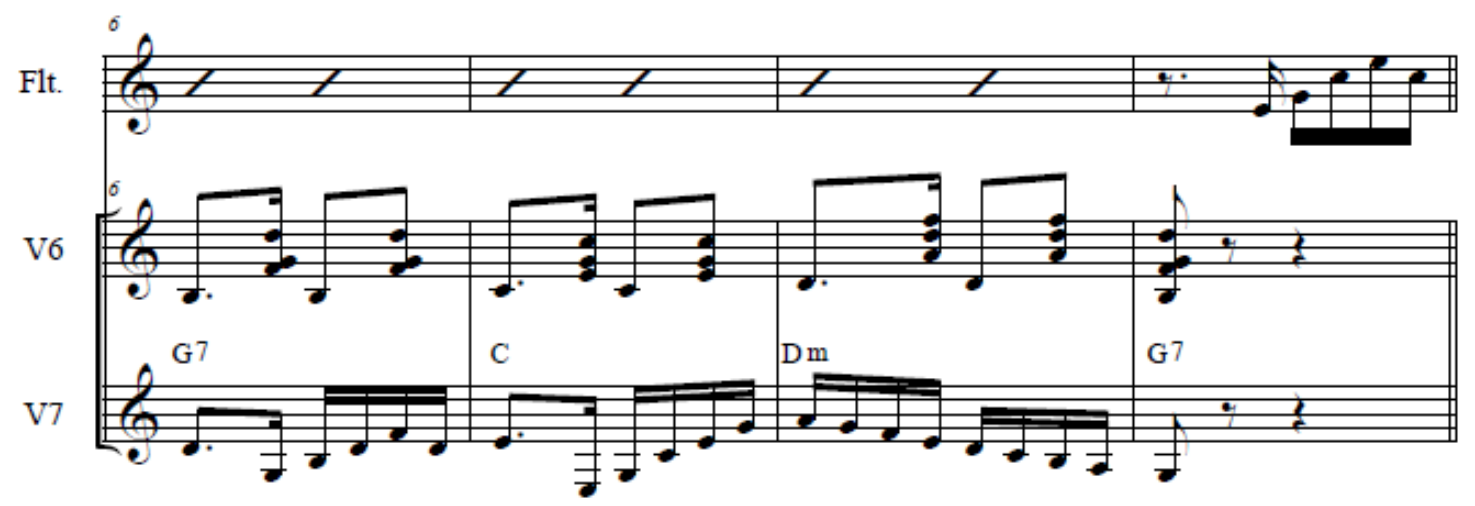

Fonte: Seu Lourenço no vinho, transcrição do autor.

O trecho acima confirma a íntima ligação entre o Maxixe, o Tango Brasileiro e a Habanera. O Choro em questão é o Seu Lourenço no Vinho, de Pixinguinha, considerado um Choro-Maxixe. É possível observar no acompanhamento do V6 a célula rítmica da Habanera, frequentemente presente nos acompanhamentos do Tango Brasileiro, como nas figuras 53 e 54. A Levada utilizada pelo V6 se mantém por quase toda a peça, confirmando a influência da Habanera no Tango Brasileiro e no Maxixe.

Carrilho (2007), em material didático, apresenta uma lista com as possibilidades rítmicas de acompanhamento do Maxixe e suas variações:

Figura 56 - Célula rítmica do Maxixe e variações. 
MAXIXE:
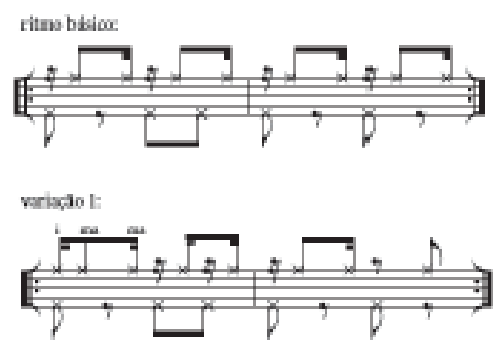

varisaca 2

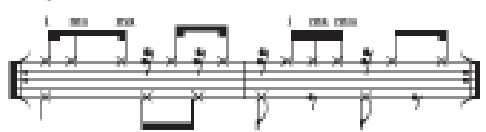

variaço 3 :

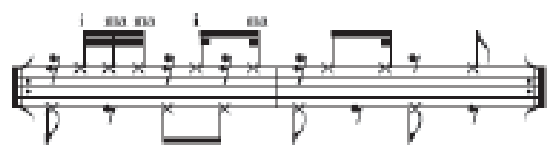

variaça 4 :

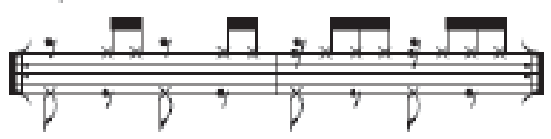

variaça 5 :

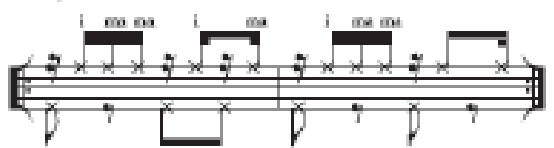

variacto 6

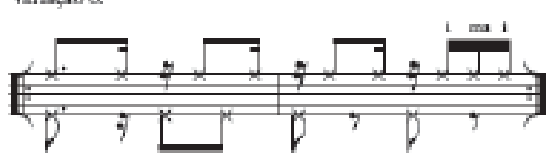

Fonte: CARRILHO (apud BITTAR, 2011).

A Valsa-Choro também faz parte ativamente do repertório dos Chorões. Braga indica os principais tipos de acompanhamento relacionado às Valsas:

Figura 57 - Tipos de Valsa-Choro.

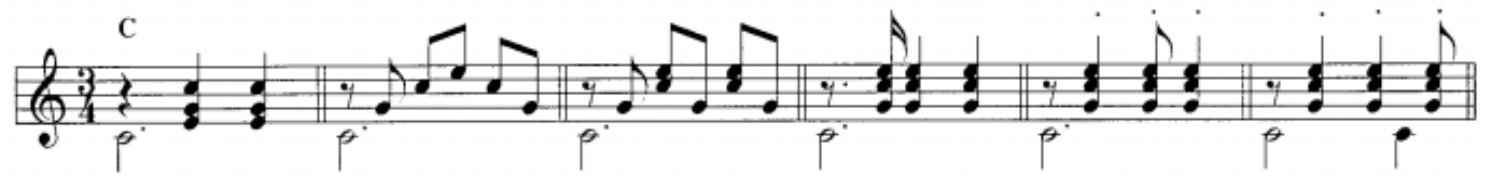

Fonte: BRAGA, 2002, p.17. 
O formato apresentado no primeiro compasso da figura anterior é o mais comum dentre as Valsas. A figura a seguir ilustra sua utilização:

Figura 58 - O acompanhamento de Valsa tipo 1- exemplo 1.

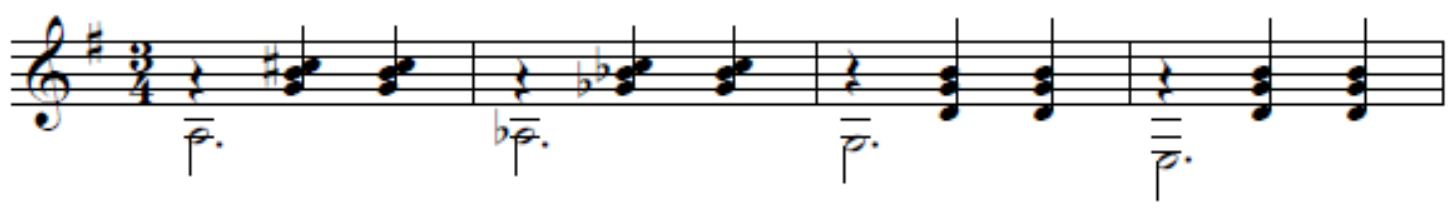

Fonte: O vôo da mosca (Jacob do Bandolim), BECKER, 1996, p. 16 dos anexos.

A figura a seguir, embora escrita de maneira diferente, ilustra basicamente a mesma ideia musical da figura anterior:

Figura 59 - Acompanhamento de Valsa tipo 1- exemplo 2.

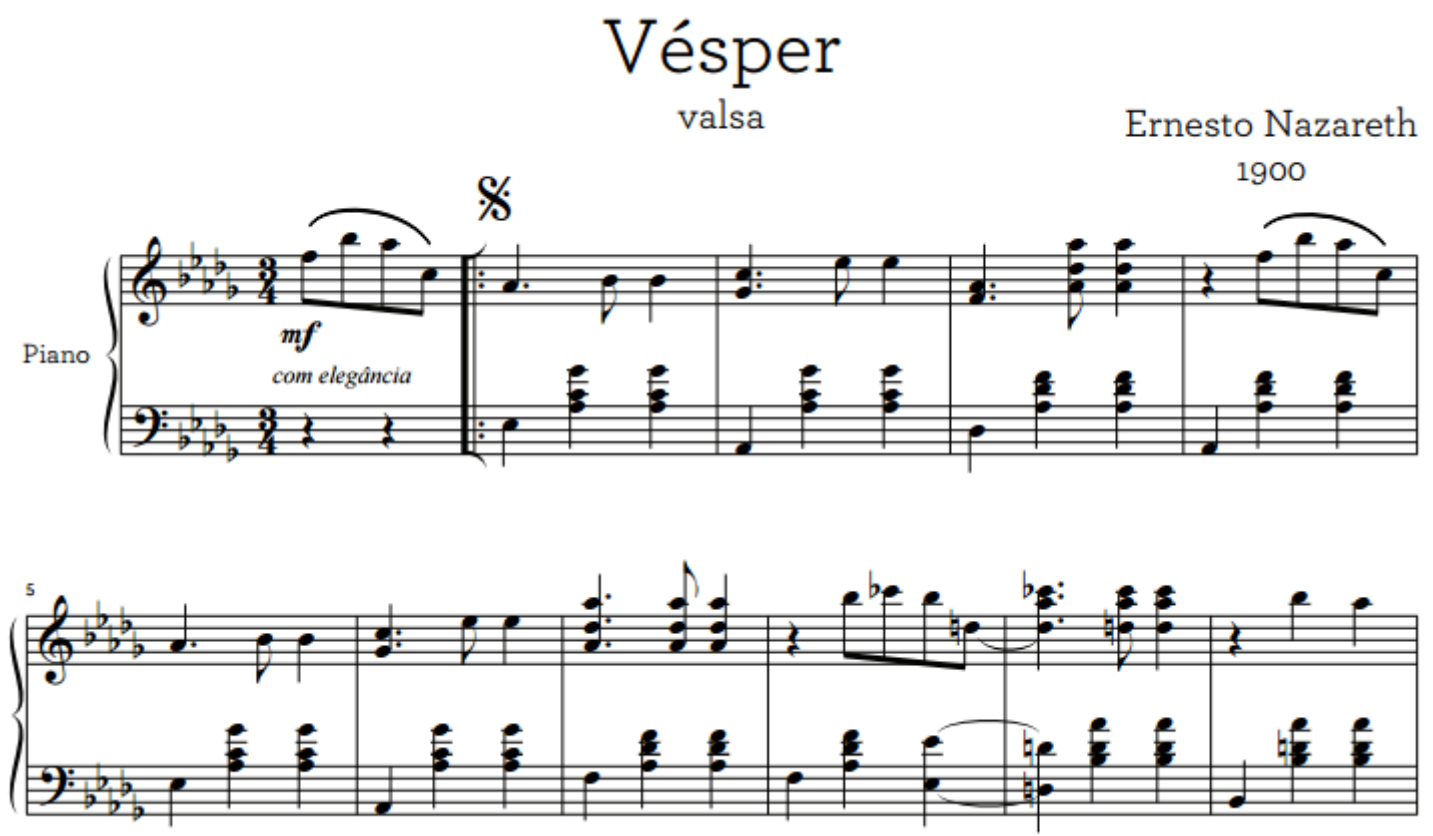

Fonte: Ernesto Nazareth, Vésper, 1900.

O formato apresentado no segundo compasso da tabela de tipificações da Valsa-Choro por Braga pode ser observado em:

Figura 60 - Acompanhamento de Valsa-Choro - tipo2. 

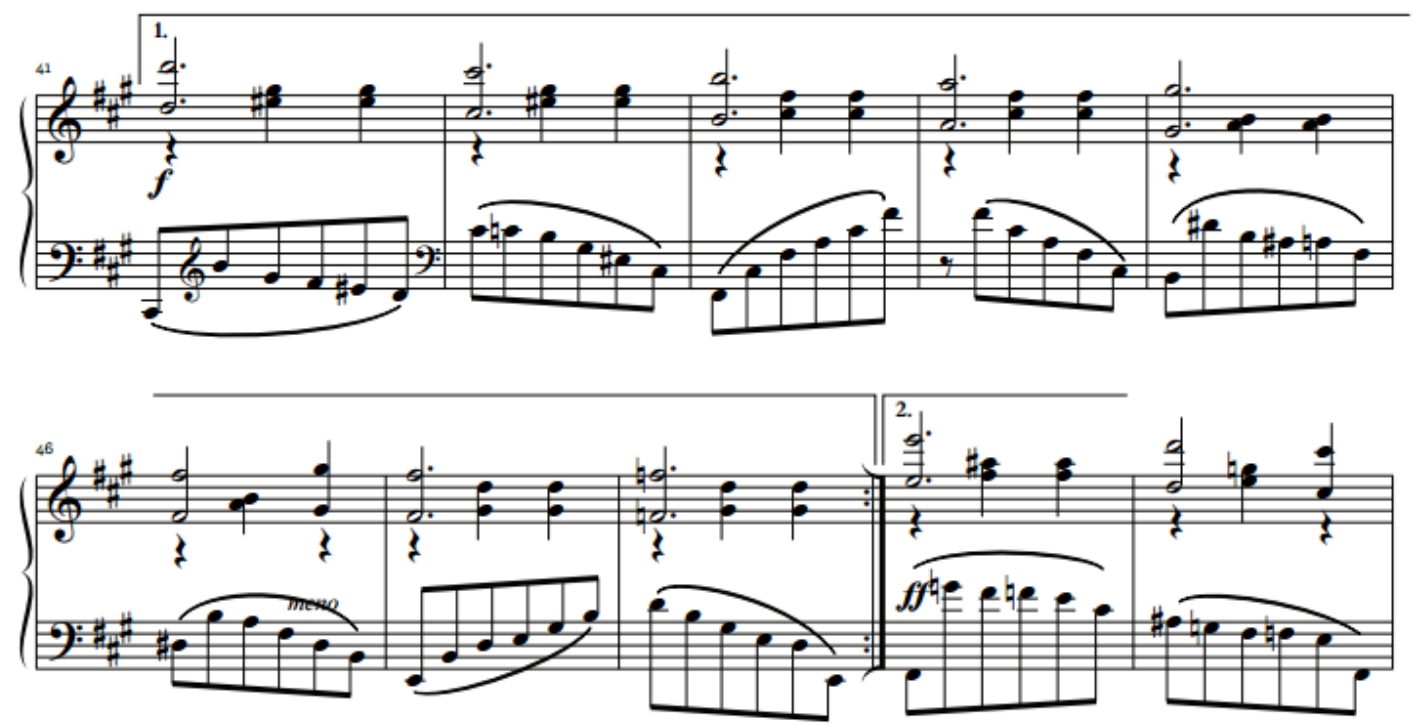

Fonte: Ernesto Nazareth, Dirce, 1926.

O exemplo acima ilustra o acompanhamento utilizando as seis colcheias dedilhadas. O exemplo abaixo, extraído da Valsa-Choro (Suíte Popular Brasileira) de Villa-Lobos se trata de uma peça para violão solo, e é possível observar a utilização dos dois tipos de Valsa citados, embora esteja num contexto de violão solo, ou seja, melodia e acompanhamento ao mesmo tempo.

Figura 61 -Valsa-Choro 


\section{Valsa-Choro}

"Suite Popular Brasileira" No. 3

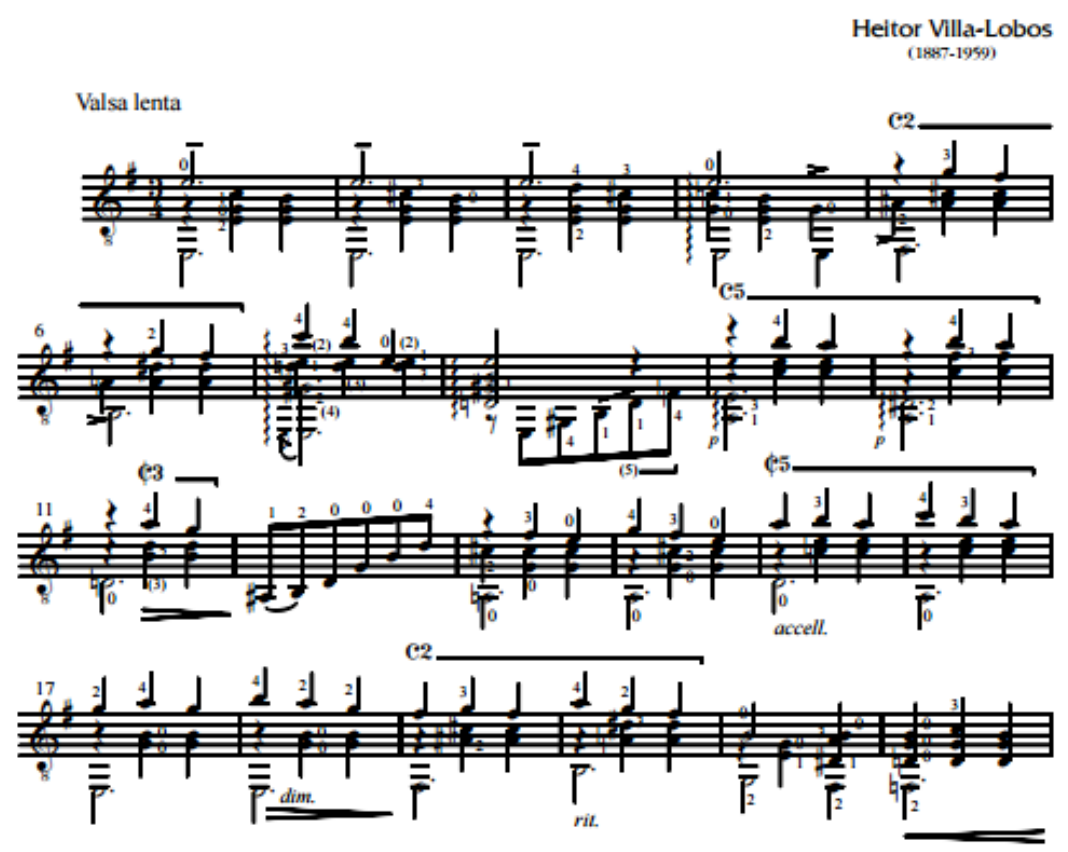

Fonte: Villa Lobos, Valsa-Choro, 1998.

A figura acima ilustra a execução da Valsa tanto com 3 semínimas como com 6 colcheias. As outras formas de acompanhamento de Valsa ocorrem em menor número, e os tipos naturalmente podem se misturar em uma mesma música. Na secção seguinte serão apresentadas as levadas de Choro propriamente ditas.

\subsubsection{A Levada do Choro}

A levada básica de Choro, assim como em muitos outros ritmos brasileiros, tem forte relação com a célula rítmica da síncope. A Levada básica pode ser definida através do seguinte desenho rítmico:

Figura 62 - Célula rítmica do Choro- tipo 1.

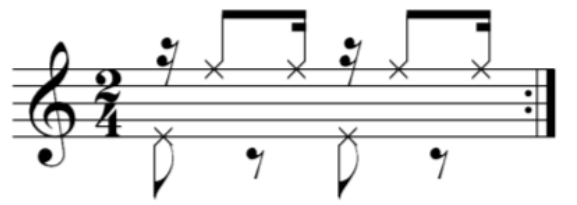

Fonte: CARRILHO (apud BITTAR, 2011). 
A figura abaixo ilustra, com nítidas semelhanças com a figura acima, uma possibilidade rítmica de acompanhamento de Choro na Bateria, sugerida pelo percussionista Oscar Bolão (2009) em seu livro “Batuque é um privilégio”:

Figura 63 - Acompanhamento de Choro na Bateria.

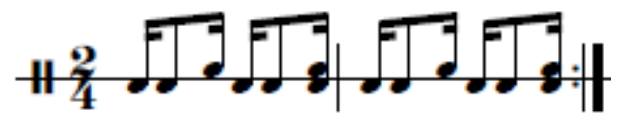

Fonte: Bolão, 2009, p.106

A figura abaixo ilustra uma forma de acompanhamento de Violão para este tipo de Choro, também conhecido como Choro-Canção:

Figura 64 - Acompanhamento básico de Choro - exemplo 1.

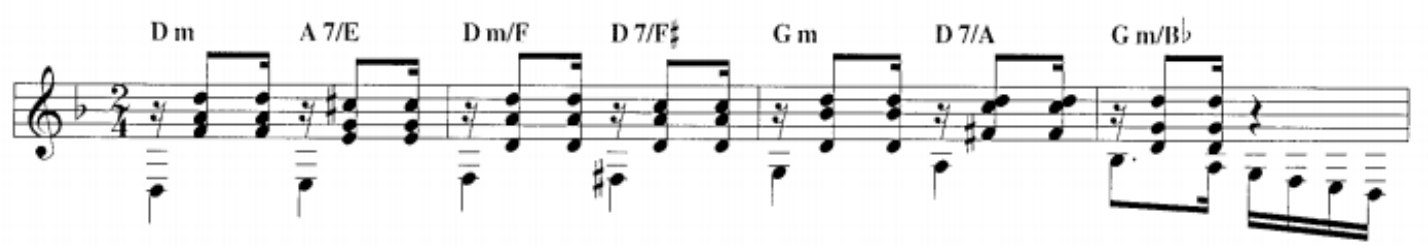

Fonte: BRAGA, 2002, p.16.

O exemplo abaixo ilustra este mesmo tipo de acompanhamento, no Choro Reminiscências, de Jacob do Bandolim:

Figura 65 - Acompanhamento básico de Choro - exemplo 2.

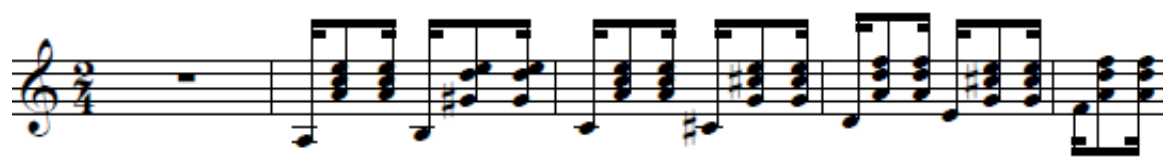

Fonte: BECKER, 1996, p.5 dos anexos - Reminiscências (Jacob do Bandolim).

A figura seguinte apresenta outra possibilidade rítmica de acompanhamento de Choro. Nesse caso, todas as semicolcheias são “preenchidas” pelo acompanhamento: 
Figura 66 - Acompanhamento de Choro - variação 1.

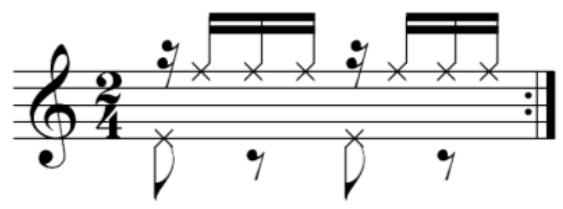

Fonte: CARRILHO (apud BITTAR, 2011).

A próxima figura ilustra uma passagem com esse tipo de acompanhamento:

Figura 67 - Acompanhamento de Choro - variação 1 - exemplo.

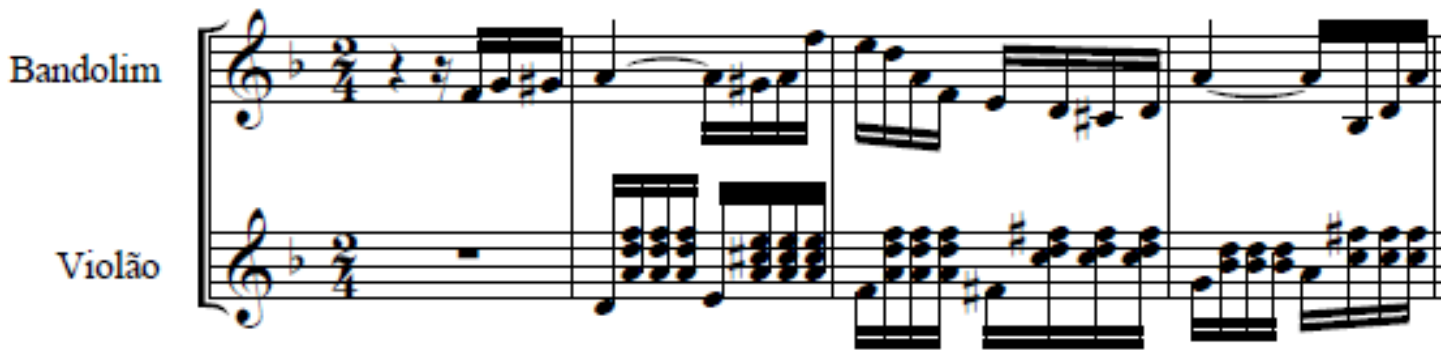

Fonte: Vibrações, transcrição do autor.

O próximo exemplo ilustra uma segunda variação da Levada de Choro, um pouco mais densa, onde é possível observar o trabalho do polegar simultaneamente ao dos outros dedos.

Figura 68 - Acompanhamento de Choro - variação 2.

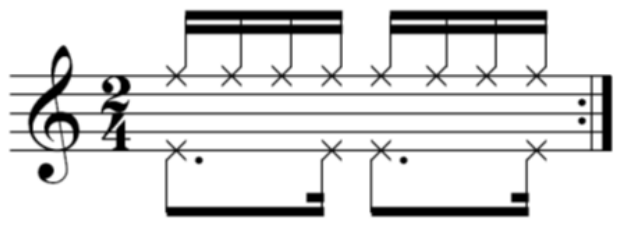

Fonte: CARRILHO (apud BITTAR, 2011).

Segue outra representação de Levada de Choro: 
Figura 69 - Levada de Choro - variação 3

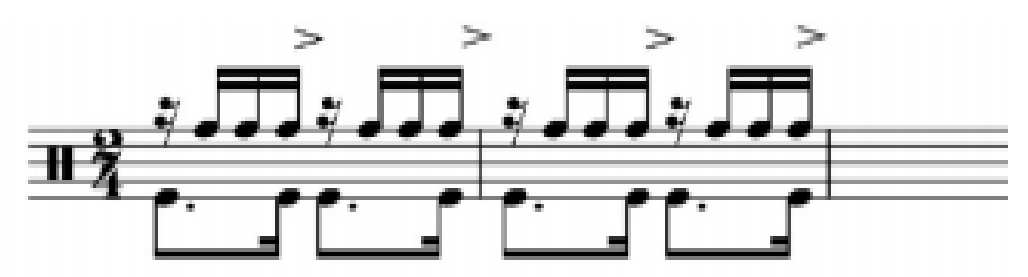

Fonte: FARIA e KORMAN, 2001, p.4.

A célula acima, apresentada como a célula do Choro no livro "Inside the brazilian rhythm section” (FARIA e KORMAN, 2001), se apresenta como uma fusão entre a variação 1 e a variação 2, correspondentes às figuras 63 e 65, respectivamente.

\subsection{3- Choro de Varanda}

Essa Levada é também conhecida no meio dos chorões como "Varandão", e é frequentemente utilizada para acompanhar sambas e choros de andamento mais lento. (Bittar, 2009).

Figura 70 - O Choro de Varanda 1.

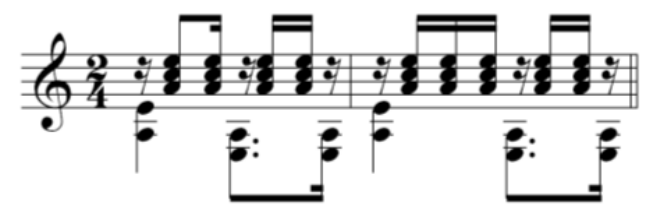

Fonte: BITTAR, 2011.

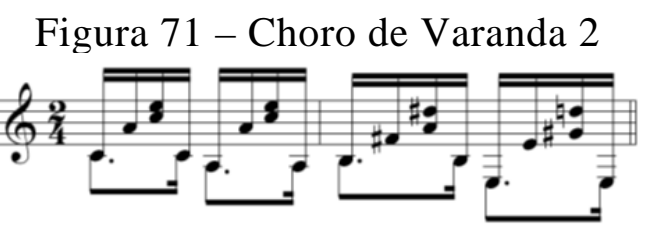

Fonte - BITTAR, 2011.

Interessante notar que em alguns momentos o dedão (ou a dedeira) produz várias notas simultaneamente. Na figura 70, isso pode ser observado no início do primeiro e segundo tempos dos dois compassos. O efeito é produzido atacando com a dedeira diferentes cordas consecutivas em sequencia rápida, de modo que se assemelhe a um ataque simultâneo. 


\subsubsection{Samba-Choro}

A Levada de Choro-sambado ou Samba-Choro surgiu sob a influência da transformação sofrida pelo Samba surgido no Estácio de Sá com Ismael Silva e compositores da escola de Samba Deixa Falar. Segundo o pesquisador Adalberto Paranhos:

Nos últimos anos da década de 1920 um terremoto de efeito prolongado abalou, de alto a baixo, a música popular brasileira. Seu epicentro foi o bairro de Estácio de Sá, encaravado entre o Morro de São Carlos e o Mangue, nas proximidades da zona central do Rio de Janeiro. (...) Quase simultaneamente, o "samba carioca", nascido na cidade, iria galgar as encostas dos morros e se alastrar pela periferia afora e, com o tempo, seria identificado como "samba de morro". (PARANHOS, 2015, p.50)

Esse “novo” Samba se distanciava ritmicamente do Maxixe - até então um dos maiores influenciadores do Choro - e acabou por exercer influência sobre o gênero (Choro) a partir, sobretudo, da intersecção de músicos de Samba e de Choro. Segundo Sève (2014, p. 1154) “Os músicos de Choro, que atuavam nas gravações de Samba, acabaram por estar entre os mais importantes mediadores na assimilação do novo paradigma rítmico”. Portanto, esses músicos tiveram papel fundamental na nova estruturação rítmica do Choro, como continua o pesquisador:

Somaram-se ainda, a Benedito Lacerda e Pixinguinha, outros músicos na mediação do "paradigma do choro-sambado", tais como o clarinetista e saxofonista Luiz Americano e, especialmente, o bandolinista e pesquisador Jacob do Bandolim, que se tornou o principal compositor e intérprete do novo estilo e peça fundamental na organização de um conjunto de Choro (SÈVE, 2014, p. 1154).

A nova base rítmica do Samba, forjada pelos compositores do Estácio, obedece aquilo que Sandroni (2001) cunhou de Paradigma do Estácio. Em diferenciação ao paradigma do Tresilo predominante do Maxixe:

Figura 72 - Paradigma do Estácio

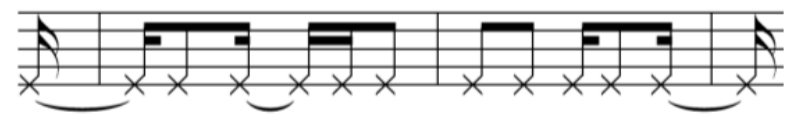

Fonte: SANDRONI, 2001.

Figura 73 - Paradigma do Estácio - variação 


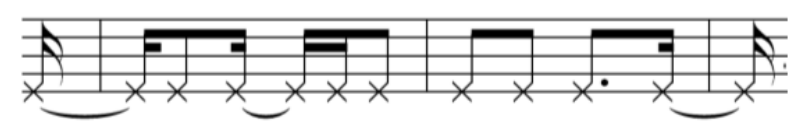

Fonte: SANDRONI, 2001.

O novo Samba, assim como o novo Choro, se voltou para o "ciclo do tamborim" ou “padrão do tamborim” (SANDRONI, 2001, p. 36), de onde surgiu a base rítmica das novas fórmulas para acompanhamentos (de percussões, cavaquinhos e violões) e de fraseados melódicos de cantores e orquestras. (SÈVE, 2014, p. 1154).

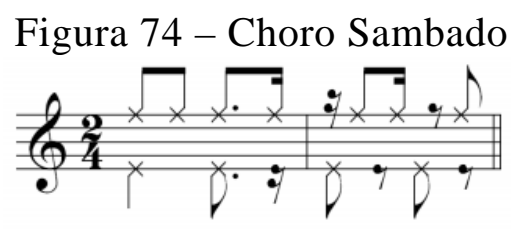

Choro sambado - exemplo Mauricio Carrilho
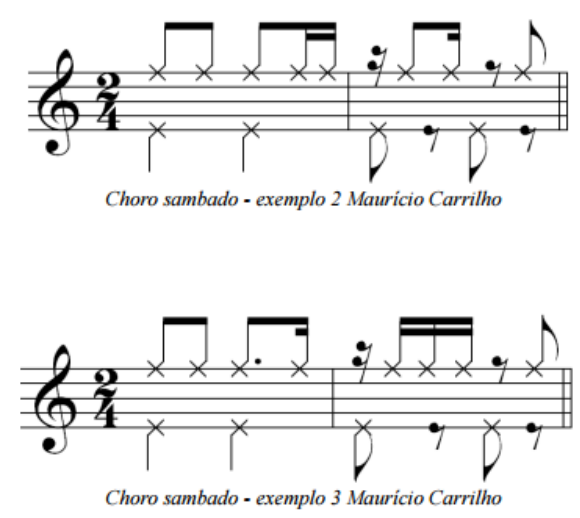

Fonte: BITTAR, 2009, p.103.

As Levadas representam, portanto, a participação do Violão na secção rítmica do Regional, operando em consonância com o Cavaco e com o Pandeiro. Simultaneamente, as Levadas remetem à complexidade da tradição rítmica afro-brasileira.

\subsection{INVERSÕES}

“(...) é importante ter o controle da harmonia sem tocar as tônicas dos acordes” (ANJOS, 2016, E., p.31). 
A partir da frase do violonista Rafael dos Anjos, podemos imaginar que, se o V6 precisa tocar sem a tônica do acorde, ele está tocando com mais alguém que irá tocá-la. Nesta e na próxima secção ficará ainda mais evidente uma característica central da performance do V6 no Choro: os diálogos íntimos com o V7! Se as habilidades musicais anteriormente descritas (a capacidade de realizar Harmonia e Levadas) já encerravam importantes relações entre V7 e V6, nas próximas duas habilidades que serão apresentadas (a capacidade de realizar Inversões e Baixarias) a evidencia de tais relações se ampliará de maneira radical.

Nesta secção, destaco o funcionamento das Inversões a partir da análise das transcrições das gravações e dos depoimentos dos chorões entrevistados.

A inversão de acordes naturalmente não é uma prática exclusiva do V6 - posto que o V7 também realiza Inversões -, e muito menos do Choro - posto que este expediente é observado em outros estilos. No período Barroco, por exemplo, é possível identificar entre suas principais novidades maior destaque ao baixo e a ocorrência de Inversões mais evidentes como informam Grout e Palisca:

O que era novo era a ênfase posta no baixo, o isolamento do baixo e do soprano como as duas linhas essenciais da tessitura e a aparente indiferença às partes internas enquanto linhas melódicas. Esta indiferença traduz-se no sistema de notação denominado baixo-contínuo: o compositor escrevia a melodia e o baixo (...) e acima das notas do baixo o executante do instrumento de teclas ou o alaudista colocava os acordes convenientes, cujas notas não estavam escritas. Se estes acordes diferiam dos acordes perfeitos no estado fundamental (...) o compositor podia indica-los através de pequenas cifras ou sinais. (GROUT; PALISCA, 1994, p.313).

Portanto, a Inversão de acordes em um instrumento existe, seguramente, pelo menos desde o período Barroco, com a funcionalização da Harmonia e o advento do basso continuo, em oposição à polifonia de vozes independentes da música do Renascimento. O basso continuo (ou baixo contínuo) além de conferir algum caráter improvisatório ${ }^{33}$ à performance instrumental de acompanhamento, possibilitou ao baixo dos acordes uma maior evidência, o que consequentemente traria também uma evidência às Inversões.

33 Segundo Grout e Palisca, a improvisação dependia da habilidade do intérprete, em suas palavras “A realização - a execução efectiva- desse tipo de baixo-cifrado variava segundo a natureza da composição e o gosto e perícia do intérprete, que ficava com uma larga margem para improvisação, no âmbito do quadro estabelecido pelo compositor.” (GROUT; PALISCA, 1994, p.313). Carpeaux confirma a liberdade dada ao intérprete: "Contudo, o instrumentalista também guarda certa liberdade. O baixo-contínuo não foi completamente escrito pelos compositores, os acordes foram notados em espécie de linguagem cifrada, em números que indicam os intervalos e que podem ser interpretados de maneiras diferentes.” (CARPEAUX, 1999, p.60) 
No contexto da Música Popular Brasileira, convém lembrar que o Maxixe já demonstrava vocação para as Inversões. Marcílio destaca o uso de acordes invertidos no Maxixe e no seu baixo “caminhante”. Em suas palavras:

Para o maxixe, em geral, o baixo é feito por instrumentos graves das bandas ou orquestras, o que na época, costumava ser executado por bombardinos, trombones e tubas, e quando no grupo de choro, pelo piano, violão ou oficleide - instrumento de chaves com o corpo cônico, hoje em desuso. Estes instrumentos tocavam muitas vezes a nota mais grave do acorde, ou uma sequência de uma progressão harmônica, ou ainda o contracanto. O maxixe apresenta muitos acordes invertidos - baixo invertido. Geralmente o gênero traz um baixo caminhante, pois tendo sua harmonia simples em termos de dissonâncias, e para dar maior interesse a esta, as inversões tornam-se essenciais. (MARCÍLIO, 2009, p. 80)

No exemplo a seguir, retirado do Tango Brasileiro Odeon, intimamente ligado ao Maxixe, é possível observar as Inversões no acompanhamento da mão esquerda logo após a anacruse inicial: C\#m/E - G\#7/D\# - C\#m - C\#/B - F\#m/A - C\#7/G\# - F\#m. Portanto, esses compassos iniciais ilustram a seguinte “melodia” nos baixos: mi - ré\# - dó\# - si - lá - sol \# fá\#.

Figura 75 - Inversões de acordes no Tango Brasileiro.

Odeon
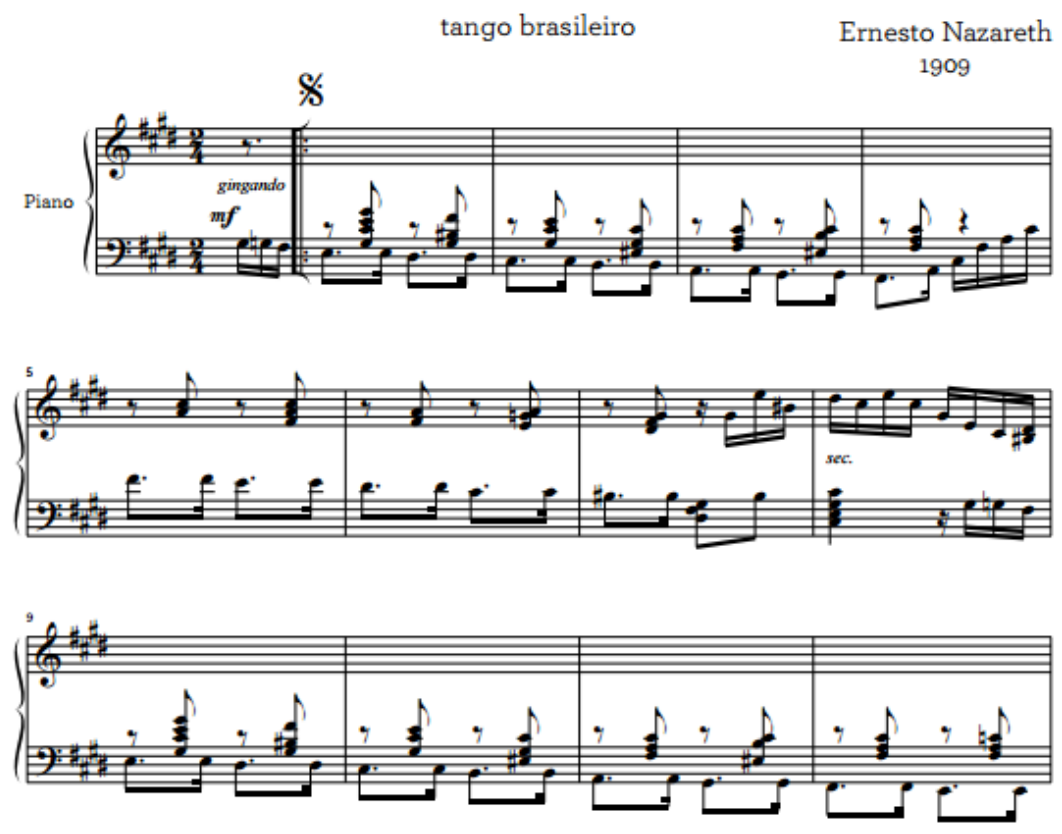

Fonte: Ernesto Nazareth, Odeon, 1909. 
Nos compassos seguintes, é possível observar outras opções por Inversões que geram baixos melódicos. Importante notar que Odeon é uma composição de 1909.

Relacionado à busca deste interesse melódico nos baixos, noto uma frequente preferência pelo caminho mais curto, gerador de uma espécie de melodia no baixo:

Figura 76 - Caminho cromático nos baixos.

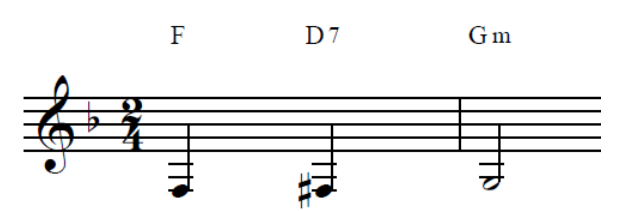

Fonte: Transcrição do autor.

A figura seguinte ilustra a performance do V7 em Vibrações, em que é possível perceber a realização de uma espécie de "baixo cromático-diatônico”, ou seja, um caminho grave que evita grandes saltos, que procura o menor caminho e “oferece” uma melodia:

Figura 77 - Baixo “diatônico-cromático”.

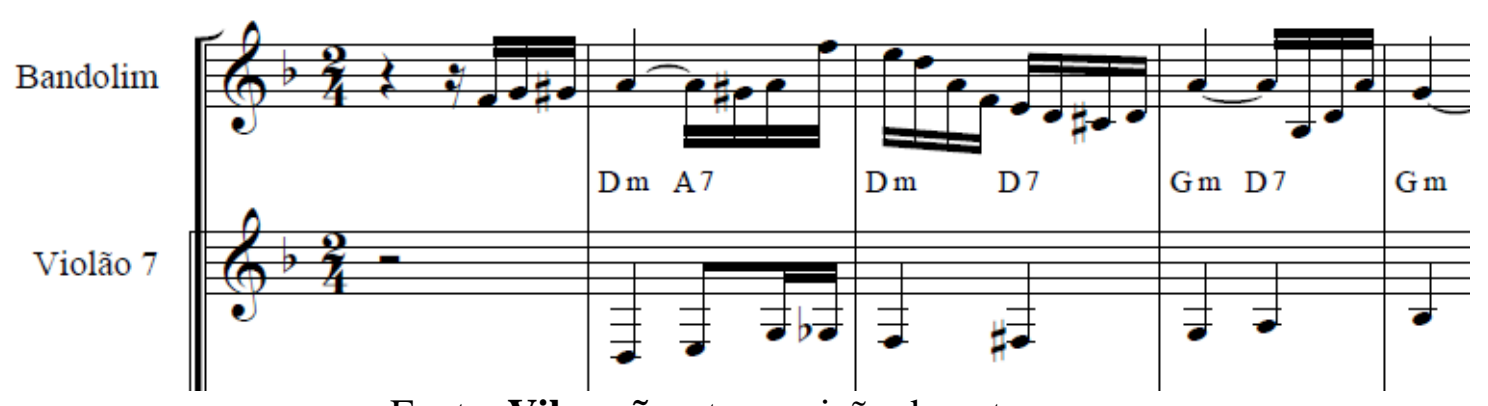

Fonte: Vibrações, transcrição do autor.

A figura anterior apresenta o caminho “cromático-diatônico” realizado pelos baixos do V7: ré mi fá fá\# sol lá sib. A partir deste e outros exemplos, noto que os violonistas - tanto os de V7 como os de V6 - prezam, em muitas situações, por evitar grandes saltos na execução dos baixos, resultando na condução harmônica mais “fechada”. Nessa perspectiva, frequentemente eles buscam tais caminhos diatônicos ou cromáticos (ou até mesmo baixospedais) no baixo (o caminho mais curto), levando-os a utilização de grande quantidade de acordes invertidos. O exemplo de Vibrações também será abordado mais adiante. O professor e violonista Luiz Otávio Braga (2002) apresenta um exemplo bastante semelhante, em seu método para V7, na tonalidade de Am: 
Figura 78 - Caminho diatônico-cromático do baixo - exemplo 2.

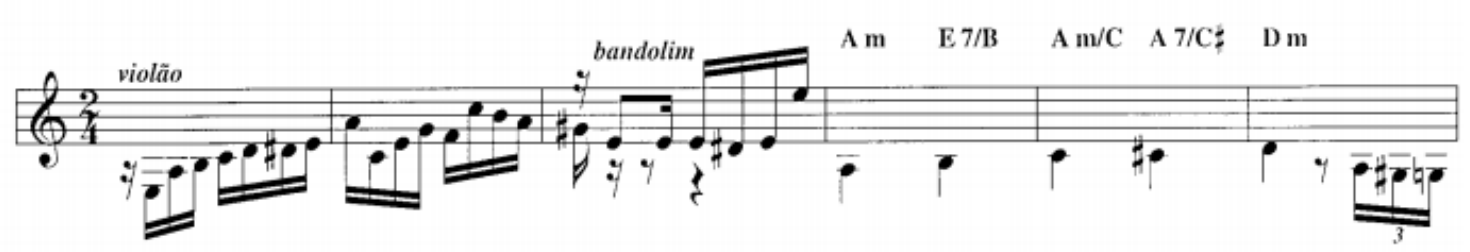

Fonte: BRAGA, 2002, p.68 - É do que há (Luiz Americano).

A figura acima ilustra o mesmo tipo de “caminho” nos baixos, embora em outra tonalidade, na música É do que há, de Luiz Americano, em gravação de Joel Nascimento. Entre os compassos 3 e 5 é possível observar a sequência das notas lá-si-dó-dó\#-ré no baixo. Situação bastante semelhante ocorre na música Reminiscências, em transcrição presente na dissertação de Becker (1996):

Figura 79 - Caminho cromático-diatônico do baixo - exemplo1.

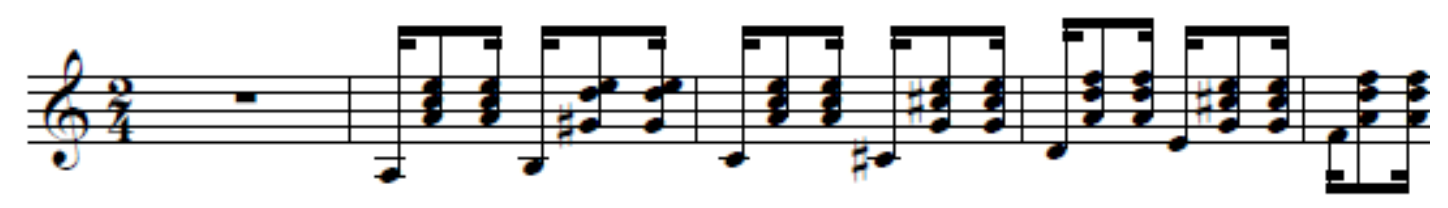

Fonte: BECKER, 1996, p.1 dos anexos - Reminiscências (Jacob do Bandolim).

O exemplo acima confirma a opção pelo “menor caminho” nos baixos, o que gera uma melodia no baixo ainda mais proeminente do que a do exemplo anterior: lá-si-dó-dó\#-ré-mifá. Este clichê harmônico (I V I V/IV IV V/IV IV genericamente, e Am E7/B Am/C A7/C\# Dm A7/E Dm/F especificamente) possibilita este tipo de condução nos baixos. Além dos exemplos apresentados (Vibrações, É do que há e Reminiscências), é possível observar este tipo de Harmonia (ou trechos dela) em muitos outros Choros (como Odeon, Murmurando, Cuidado violão, dentre outros), tornando possível a realização do mesmo tipo de ideia na condução nos baixos.

No entanto, além da questão individual do interesse pela “melodia do baixo” (que será aprofundada na secção das Baixarias) convém lembrar que, mesmo antes da introdução do V7 no Choro era usual que os violonistas de 6 cordas, já em duetos, procurassem complementaridades em suas execuções, num contexto mais coletivo. Para evitar redundâncias na disposição dos acordes, principalmente no baixo, os violonistas costumam dominar o universo das Inversões. O violonista Fernando César assim discorre ao responder sobre as principais habilidades musicais do V6: “Outro papel do V6 é aquela coisa de segurar 
a harmonia, invertendo os baixos e andando distante do primeiro violão”. (CÉSAR, 2015, E., p.26). Como apresento adiante, a expressão “invertendo os baixos e andando distante” evoca a ideia de complementaridade. O experiente músico José Américo aponta que “O V6 vai junto com o V7. O músico precisa saber fazer um segundo violão, acompanhar o V7 naquela coisa bonita. É complementar!”. (AMÉRICO, 2016, E., p.4).

Portanto, o controle sobre as Inversões irá render ao violonista boas respostas à execução do V7 (ou do outro V6, como ocorria no passado, antes da implementação do V7 no Choro). Segundo o violonista Rafael dos Anjos, a complementaridade entre os violões é característica marcante do Choro, e entre as principais habilidades do V6 está: "Trabalhar sempre com inversões, sempre completando as vozes tonais do V7, assim trazendo uma sonoridade única, rica, singular e brasileiríssima: a linguagem do Choro”. (ANJOS, 2015, E.p.,32). O violonista José Paulo Becker (2015, E., p.40) reforça a importância do domínio desta habilidade: "É muito importante saber as inversões dos acordes”.

É preciso salientar que no contexto do Choro o conceito de Inversão no Violão está relacionado, normalmente, mais à disposição do baixo do que às outras notas do acorde. Para exemplificar, tomemos o acorde de $\mathrm{F}^{34}$. De maneira geral, a Inversão nada significa senão em qual nota do acorde está no baixo, independentemente da disposição das outras notas diferentes do baixo:

Quadro 7- Acorde de F e suas inversões

\begin{tabular}{|l|}
\hline $\begin{array}{l}\text { F é o estado fundamental } \\
\text { (independentemente da disposição das notas mais agudas que o baixo) }\end{array}$ \\
\hline $\begin{array}{l}\text { F/A é a primeira inversão } \\
\text { (independentemente da disposição das notas mais agudas que o baixo) }\end{array}$ \\
\hline $\begin{array}{l}\text { F/C é a segunda inversão } \\
\text { (independentemente da disposição das notas mais agudas que o baixo). }\end{array}$ \\
\hline
\end{tabular}

Fonte: elaboração do autor.

No contexto prático, é frequente que, se o V7 repousa sobre o acorde em estado fundamental, o V6 repouse sobre o acorde na primeira inversão, gerando um intervalo de terça no baixo. De forma análoga, se o V7 repousa sobre a primeira inversão, uma opção bastante provável para o V6 seria repousar sobre a segunda inversão, novamente gerando um intervalo de terça. No exemplo seguinte é possível observar as duas situações:

\footnotetext{
${ }^{34}$ Podemos estender esse raciocínio a todas as outras categorias de acordes. Naturalmente, os acordes formados por tétrades (Dominantes, Diminutos e Meio-diminutos) terão uma inversão a mais.
} 
Figura 80 - Inversões gerando intervalos de terças.

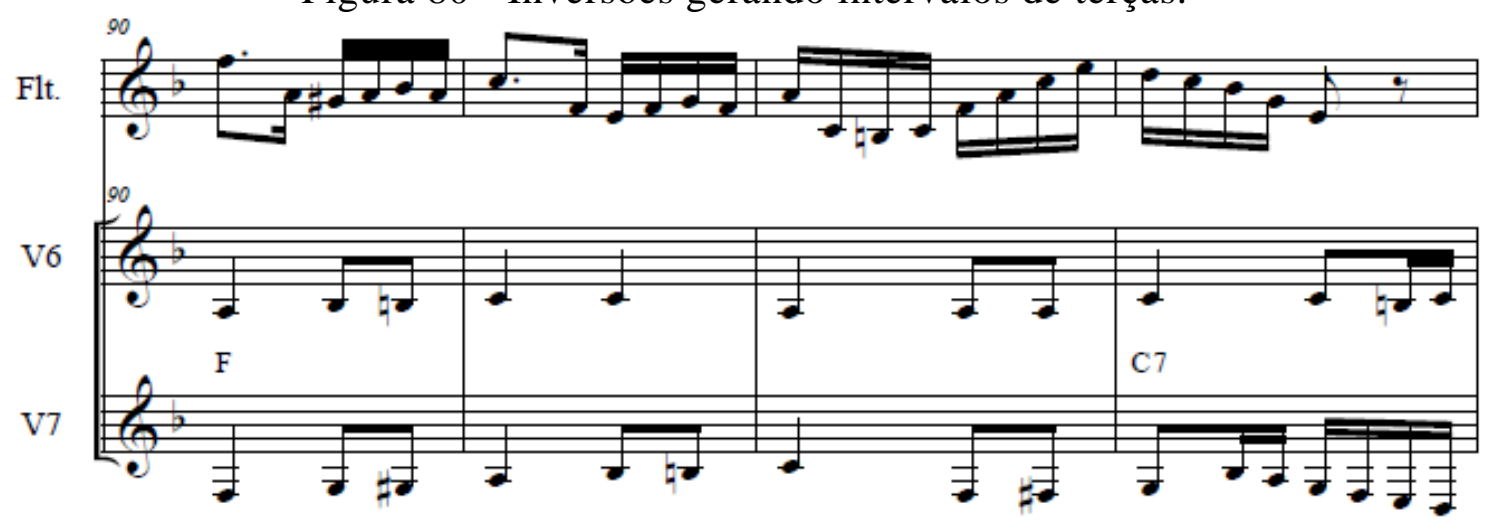

Fonte: Seu Lourenço no vinho, transcrição do autor.

Nesta transcrição, podemos observar, no compasso 90, que, enquanto o V7 realiza um F (estado fundamental), o V6 realiza um F/A (primeira inversão). Já no compasso seguinte, o V7 realiza um F/A (primeira inversão) que é prontamente “respondido” com um F/C (segunda inversão) pelo V6. Nos dois casos, os baixos perfazem um intervalo de terças entre eles.

Voltando ao exemplo anteriormente comentado de Vibrações, é importante observar mais detalhadamente a performance do V6. No exemplo em questão (figura 76), vimos que o V7 realiza um consistente caminho melódico nos baixos: Dm A7/E - Dm/F D7/F\# - Gm D7/A - Gm/Bb. Frequentemente, o V6 realiza este tipo de situação com os baixos oitavados:

Figura 81 - Baixos oitavados.

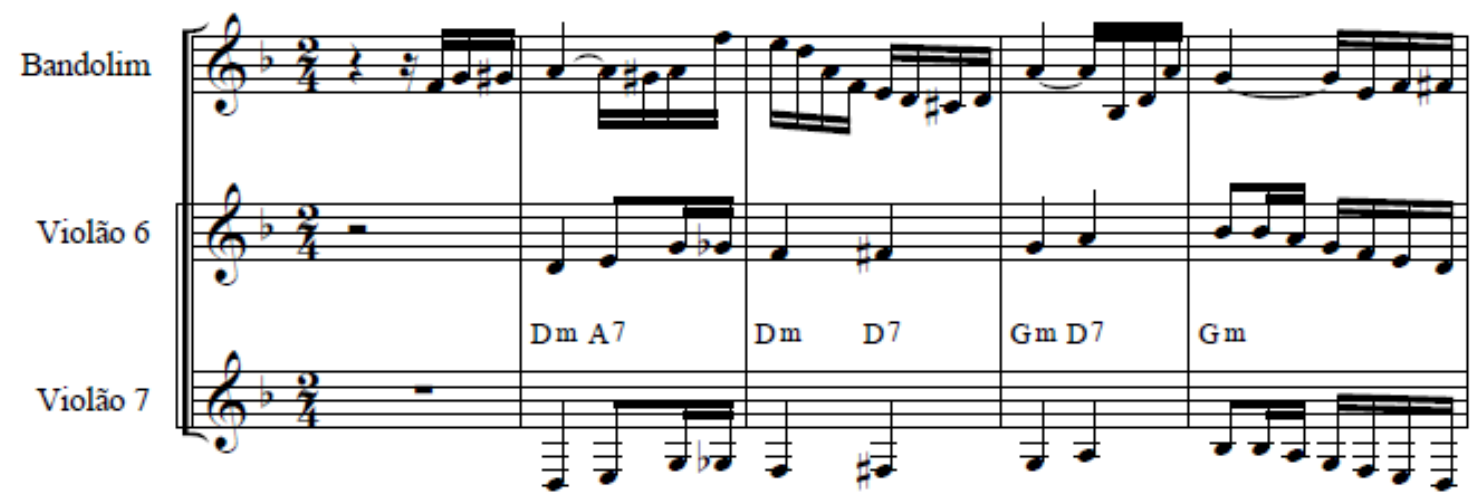

Fonte: Vibrações, transcrição do autor.

A execução em oitavas reforça a melodia do baixo e "timbra" melhor o V7. Becker (1996, p.134) afirma que “o trabalho do V7 em um arranjo depende muito de ele estar sendo acompanhado por um bom V6”. Neste mesmo caso, a opção de realizar a Inversão em Terças 
é também possível nesse caso, o que geraria uma timbragem ainda mais idiomática, aquilo que o violonista Rafael dos Anjos descreveu anteriormente como uma “sonoridade única”.

Figura 82 - Inversões em Terças - exemplo 1.

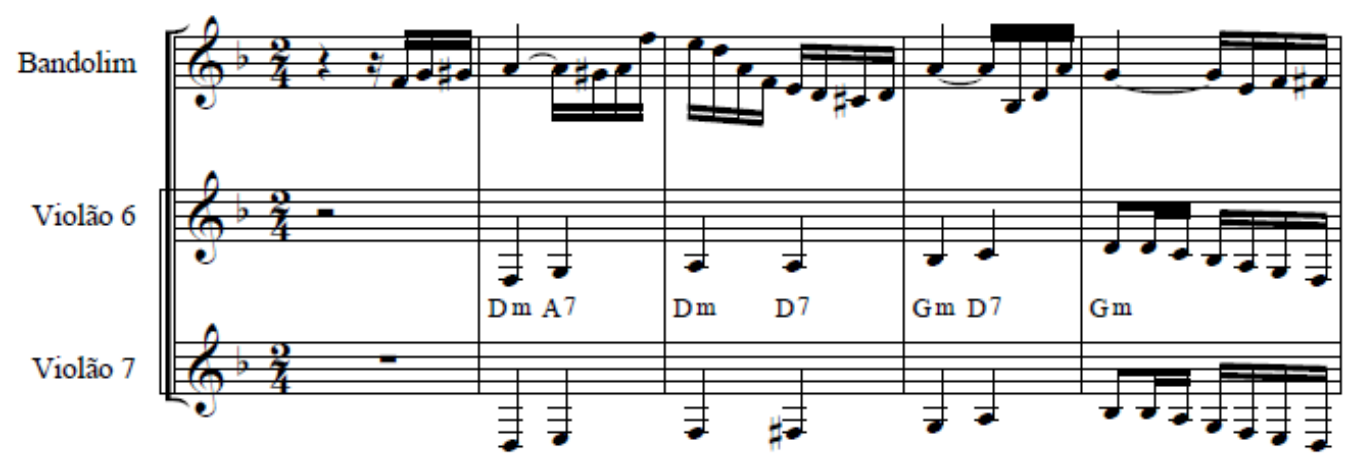

Fonte: Vibrações, transcrição do autor.

No caso de realizar o trecho em Terças, a realização do V6 seria: Dm/F A7/G - Dm/A D7/A - Gm/Bb D7/C - Gm/D. Esta disposição de inversões também possui forte identidade melódica nos baixos. Sabe-se que a 5J de Dm é a mesma 5J de D7, a nota lá. Este fato gera uma repetição de nota no baixo do V6 no segundo compasso - Dm/A D7/A - o que não diminui a consistência do contraponto, uma vez que o V7 irá gerar movimento ascendente no mesmo trecho - Dm/F D7/F\#.

Na figura abaixo, comportamentos semelhantes são observados, reforçando a tese das complementaridades dos violões no Choro e do preenchimento tonal das vozes do V7 realizado pelo V6:

Figura 83 - Inversões em terças - exemplo 2.

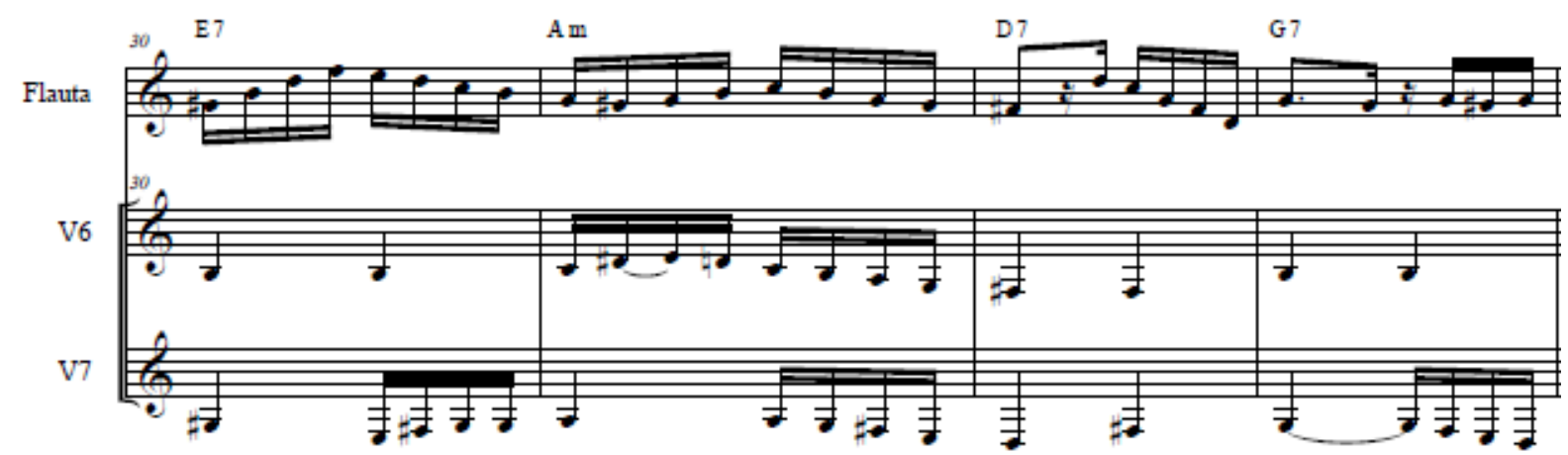

Fonte: Seu Lourenço no vinho, transcrição do autor. 
Na figura 80 são observadas Inversões em terças. No compasso 30, o V7 realiza E7/G\# (primeira inversão) e o V6 responde com E7/B (segunda inversão). No início do compasso 31, o V7 executa Am e o V6 complementa com Am/C, novamente em terças, porém, na primeira inversão. No primeiro tempo do compasso 32 destaca-se o V7 em D7 e o V6 em D7/F\# e no primeiro tempo do compasso 33, o V7 executa o baixo em G7 e o V6 em G7/B, configurando outra vez o intervalo de terça no baixo. A figura também apresenta inversões geradoras de intervalo de terça entre os violões.

Figura 84 - Inversões em terças - exemplo 3.

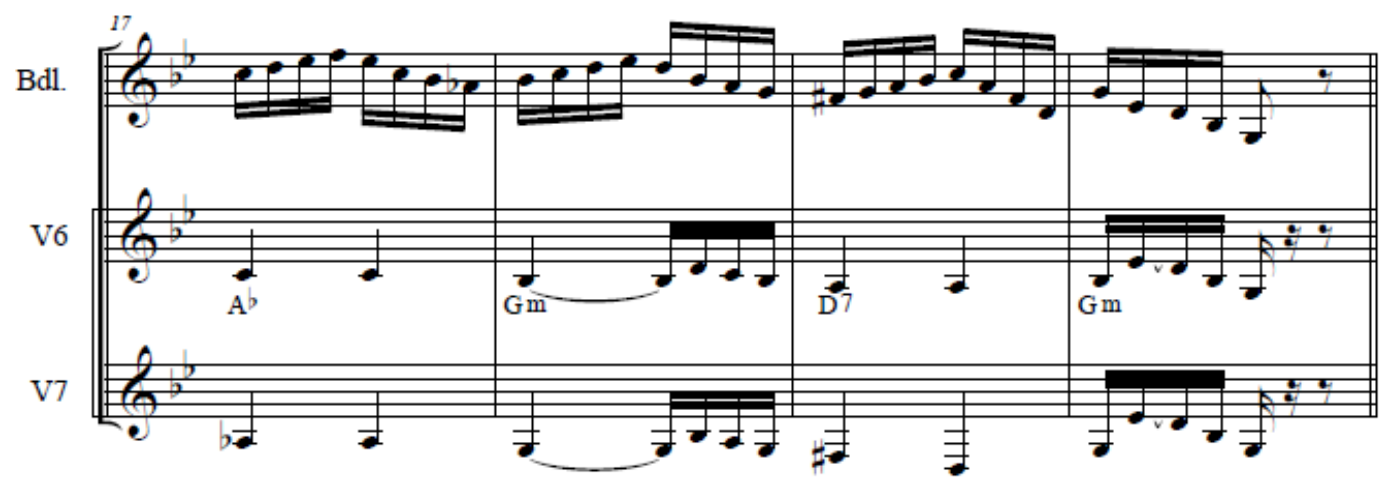

Fonte: Enigmático, transcrição do autor.

O exemplo acima apresenta inversões em terças em todos os inícios de compasso. No compasso 17, os violões estão em terças com V7 em Ab e V6 em Ab/C. No início do compasso 18, o V7 está em Gm e o V6 está em Gm/Bb, novamente em terças. No início do compasso 19, o V7 está na primeira inversão (D7/F\#) e o V6 está na segunda inversão (D7/A). No início do compasso 20, o intervalo em terça é repetido, com Gm para o V7 e $\mathrm{Gm} / \mathrm{Bb}$ para o V6.

Figura 85 - Inversões em terças - exemplo 4. 


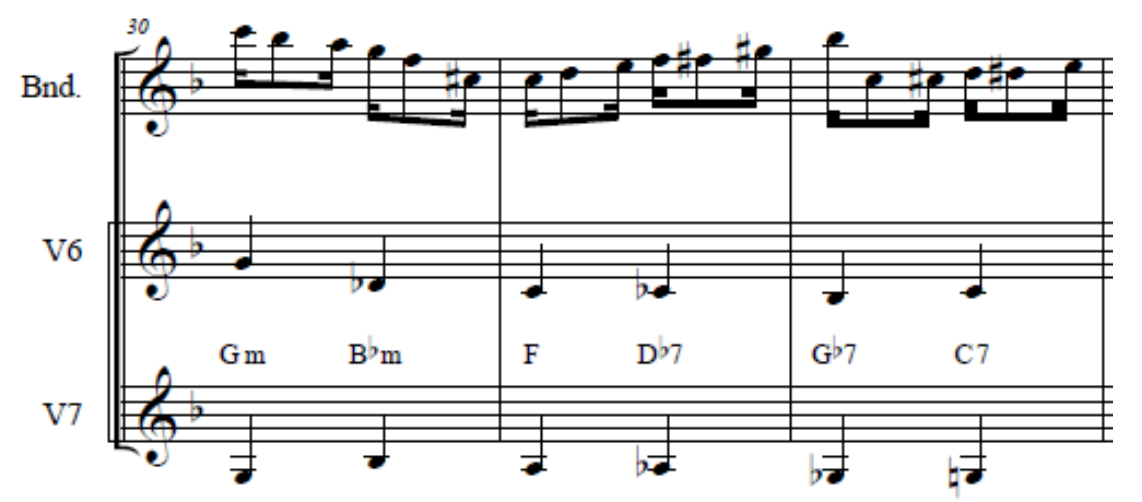

Fonte: Chorinho na praia, transcrição do autor.

Na figura anterior os violões estão oitavados no início do compasso 30. No entanto, a partir do segundo tempo, eles seguem em terças até o início do compasso 32. No segundo tempo do compasso 30, V7 executa Bbm e V6 realiza Bbm/Db. No primeiro tempo do compasso 31, V7 executa F/A (primeira inversão) e V6 responde com F/C (segunda inversão). No segundo tempo do mesmo compasso, V7 executa Db7/Ab (segunda inversão) e V6 executa $\mathrm{Db} / \mathrm{Cb}$ (terceira inversão do acorde dominante). No início do compasso 32, os violões estão novamente em terças, com Gb7 para o V7 e Gb7/Bb para o V6.

No segundo tempo do compasso 32 da figura 85 os violões estão em um intervalo de quarta, com C7/G para o V7 e C7 para o V6. Portanto, apesar de muito menos frequentemente, alguns outros intervalos (além dos frequentes intervalos de oitava e de terça) podem ocorrer, sobretudo os de quarta, os de sexta e até mesmo os de segunda. Tais questões serão exploradas mais profundamente na secção Baixarias.

\subsubsection{Ciclo de Quartas Dominantes, Condução Cromática.}

Sob um ciclo de quartas com acordes dominantes, existem dois caminhos cromáticos descendentes possíveis, frequentemente utilizados pelos chorões:

Figura 86 - Caminho cromático sobre ciclo de dominantes - exemplo 1.

A7/C\#, D/C, G7/B, C/Bb, etc: 
$\begin{array}{llllll}\text { A7 } & \text { D7 } & \text { G7 } & \text { C7 } & \text { F7 } & \text { Bb7 }\end{array}$

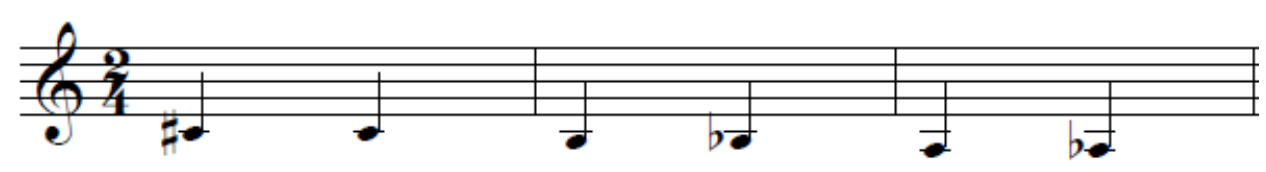

Fonte: Transcrição do autor.

Na figura 82 a condução cromática se inicia na terça do acorde A7 (dó\#), passando à sétima do acorde de D7 (dó), novamente à terça de G7 (si) e à sétima de C7 (sib), e assim por diante. Podemos observar esta aplicação no exemplo a seguir:

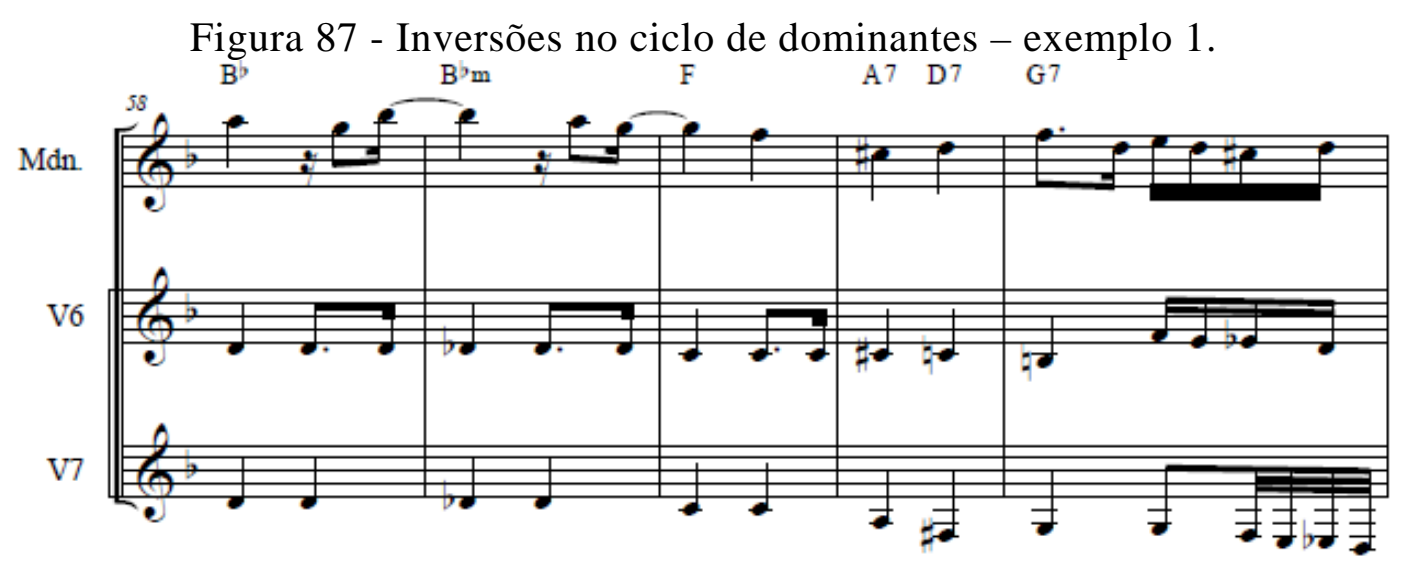

Fonte: Vibrações, transcrição do autor.

Na figura 83, o V6 realiza um caminho cromático nos baixos sobre o ciclo de dominantes presentes nos compassos 61 e 62: dó\#, dó e si.

Figura 88 - Caminho cromático sobre ciclo de dominantes - exemplo 2.

A/G, D7/F\#, G/F, C7/E etc:

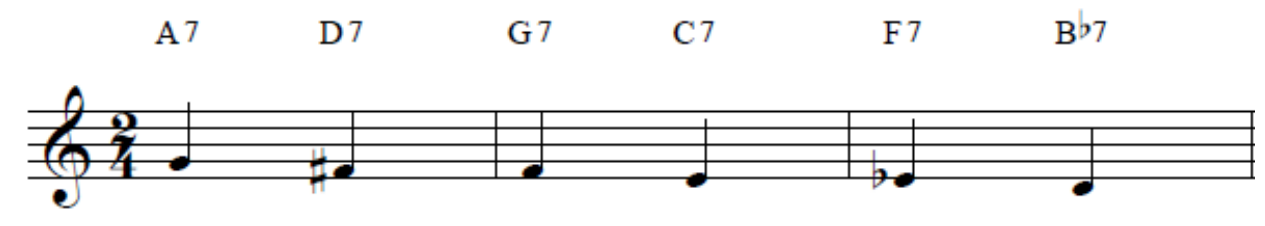

Fonte: Transcrição do autor.

Nesta outra possibilidade descrita na figura 84, a condução se dá de maneira análoga, entretanto, começa pela sétima do A7 (sol), indo à terça de D7 (fá\#) e, assim sucessivamente, por uma outra possibilidade de caminho cromático. Neste segundo caso, com o baixo na 
quarta corda, é comum que os chorões suprimam a nota do acorde gerada na corda mi, formando acordes dominantes com apenas 3 notas:

Figura 89 - Acordes invertidos e reduzidos sobre ciclo de dominantes.

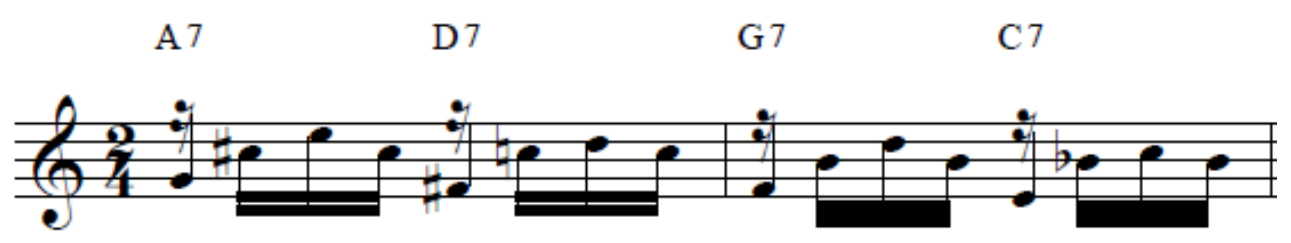

Fonte: Transcrição do autor.

A supressão de uma nota da tétrade dominante não gera nenhum prejuízo harmônico relevante, pois se tratam de tônicas ou quintas do acordes (as notas do trítono - terça e sétima são realizadas nesta digitação), e certamente realizadas pelos demais instrumentos de Harmonia. Além disso, tais supressões aumentam a eficiência da condução rítmica a ser realizada pelo violonista.

Figura 90 - Inversões no ciclo de dominantes - exemplo 2.

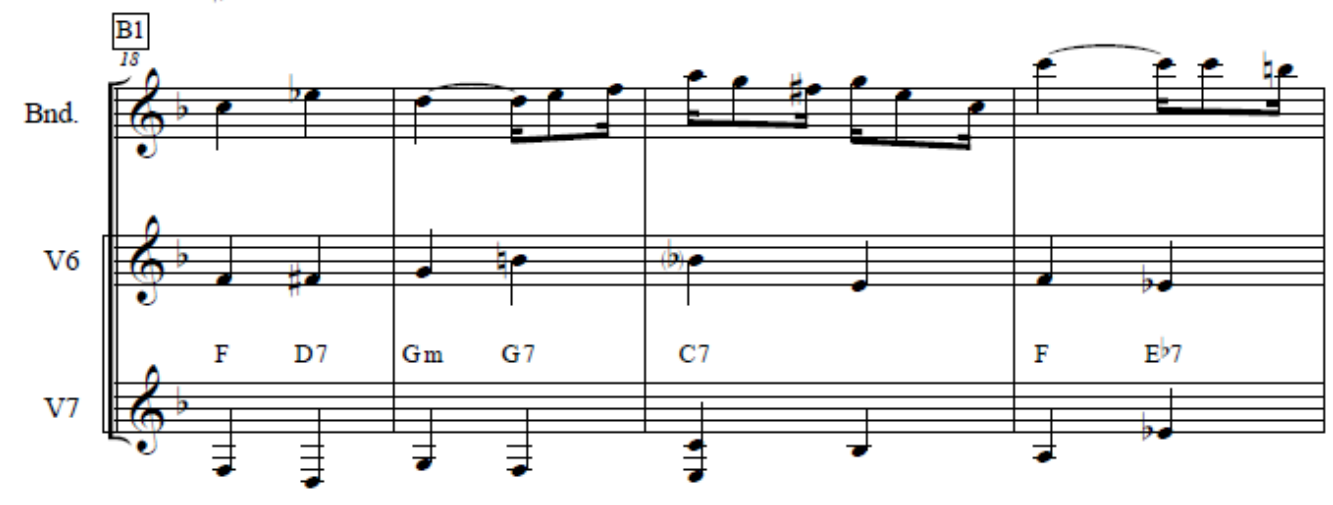

Fonte: Chorinho na praia, transcrição do autor.

Na figura acima é utilizada a condução cromática pelo V6 entre os compassos 19 e 20, sobre os dominantes G7 e C7. No segundo tempo do compasso 19, o V6 utiliza o baixo na terça (G7/B) e chega ao compasso 20 com o baixo na sétima (C/Bb), realizando uma passagem cromática entre acordes dominantes separados pelo intervalo de quarta.

\subsubsection{Inversões que resultam no Acorde Meio-Diminuto}


Nessa situação, as tensões são geralmente evitadas nos acordes maiores e menores. Como exceção a essa regra, percebemos uma utilização do Acorde Menor com a tensão de sexta frequentemente no baixo. Esta utilização ocorre principalmente em 3 diferentes situações, que serão exemplificadas a seguir.

Figura 91 - Inversão no IV em direção ao I, em tonalidade menor.

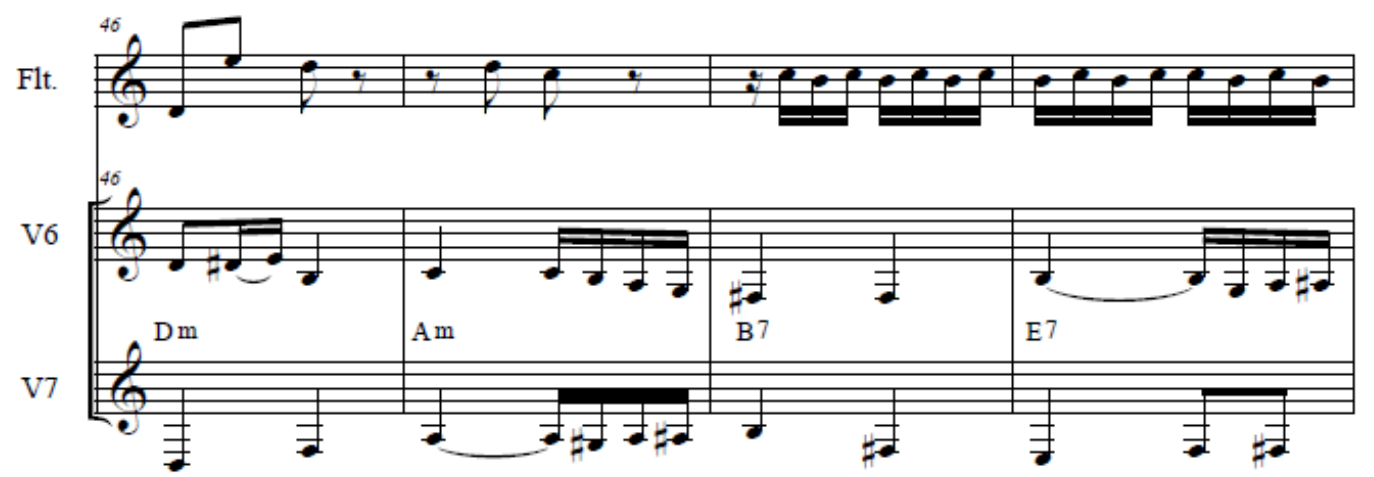

Fonte: Seu Lourenço no Vinho, transcrição do autor.

A figura ilustra o acorde menor com o baixo na 6M. No segundo tempo do compasso 46, sobre o acorde de Dm, o V6 utiliza a inversão com o baixo na nota SI, ou seja, a sua 6M, transformando-se no acorde Bm7(b5). De certa forma, esta situação pode ser encarada como uma espécie de preparação para Am, uma vez que o acorde Bm7(b5) pode ser encarado como II da tonalidade de Am.

Figura 92 - Inversão em direção à modulação para o V menor.

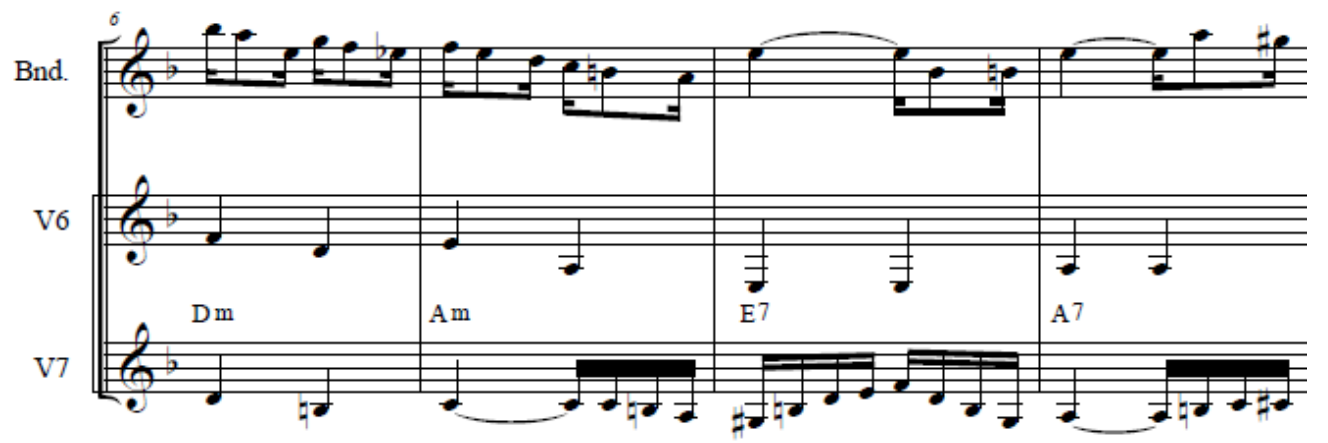

Fonte: Chorinho na praia, transcrição do autor.

A figura acima ilustra uma modulação passageira para o V menor (Am) da tonalidade (Dm). De maneira semelhante à da figura 87, o Dm se transforma em Bm7(b5) como se preparasse a tonalidade de Am, malgrado a ausência do dominante. Neste caso, porém, além de se tratar de uma modulação passageira, é possível notar que o V7 utiliza a inversão com o 
baixo na sexta do acorde (no segundo tempo do compasso 6), com Dm/B - Bm7(b5) - para o V7 e Dm para o V6, configurando um intervalo de terça. No primeiro tempo deste compasso (6), os violões também estão em terças, com Dm para o V7 e Dm/F para o V6. Ou seja, neste compasso V7 e V6 estão sempre em terças.

Figura 93 - Inversão sobre AEM, em tonalidade maior.

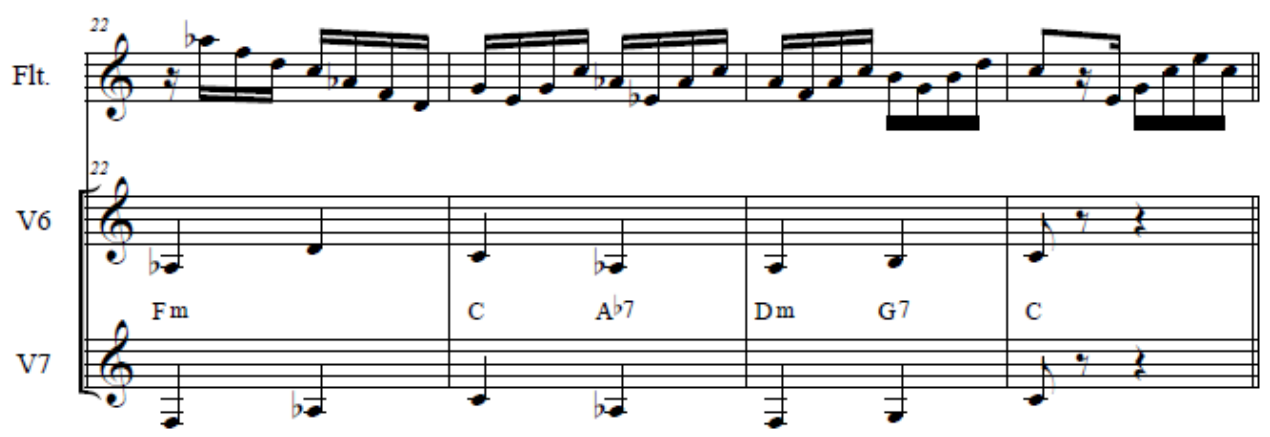

Fonte: Seu Lourenço no vinho, transcrição do autor.

Na figura 89, no compasso 22, a música está sob a tonalidade de C e enquanto o V7 está realizando o acorde de empréstimo modal Fm, no estado fundamental, o V6 realiza a primeira inversão Fm/A no primeiro tempo. No segundo tempo do mesmo compasso, o V7 realiza Fm/A, enquanto o V6 prefere, ao invés de Fm/C, a inversão Fm/D, ou seja, Dm7(b5). O acorde de Dm7(b5) continua a ser um acorde de empréstimo modal, pois é gerado como o II na tonalidade homônima, Cm.

\subsubsection{Inversões com o V7 repousado na sétima do Acorde Dominante}

Nesse tipo de execução, duas situações diferentes são observadas quando a baixaria repousa na sétima menor de um acorde dominante, a depender se é uma preparação para um acorde menor ou para uma acorde maior. Quando este acorde prepara um acorde menor, por exemplo, C7 preparando Fm, a Inversão, ou seja, o baixo do V6 se comporta normalmente, no intervalo exato de terça (terça menor, particularmente). Ou seja, se o V7 realiza C/Bb, o V6 poderá realizar uma espécie de C7/Db nesse contexto. Podemos imaginar que isso ocorre por que o acorde diminuto é (assim como o próprio acorde dominante) uma das poucas tétrades recorrentes no contexto do Choro. Ao assumir que o ambiente de tonalidades menores no Choro normalmente é o ambiente da escala menor harmônica (sobretudo sobre o I e o V graus 
da tonalidade), a tensão b9 que ocorre é uma tensão disponível para a preparação de acordes menores:

Figura 94 - Escala menor harmônica de Fm.

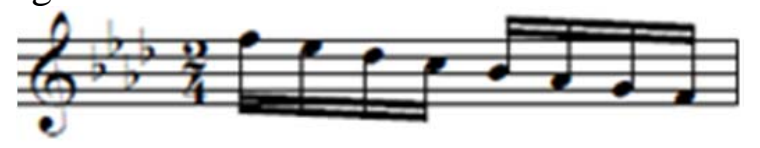

Fonte: Transcrição do autor.

A nota réb, presente na escala geradora Fm harmônica, irá, aparecer como tensão disponível (b9) para o acorde preparatório, C7. Portanto, normalmente é aceito o uso da tensão b9 no acorde dominante para preparar acordes menores, garantindo a "ambiência" menor harmônica. Quando a tensão b9 estiver no baixo, o acorde C7(b9) se mistura ao acorde Dbdim, posto que este último possui todas as notas do primeiro, com exceção da tônica, a nota Dó.

Figura 95 - correspondência funcional entre C7(b9) e Dbdim.

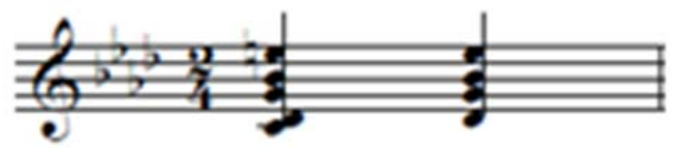

Fonte: transcrição do autor.

Portanto, o acorde Dbdim é utilizado como a inversão do acorde $\mathrm{C} / \mathrm{Bb}$, respeitando o intervalo exato de terça, algo como a "quarta inversão" do acorde de C7, com o baixo na tensão b9 - uma espécie de D7/Eb. No Choro, os acordes diminutos são, portanto, frequentemente utilizados como Acordes Dominantes preparatórios de acordes menores:

Figura 96 - Acorde diminuto utilizado como acorde dominante.

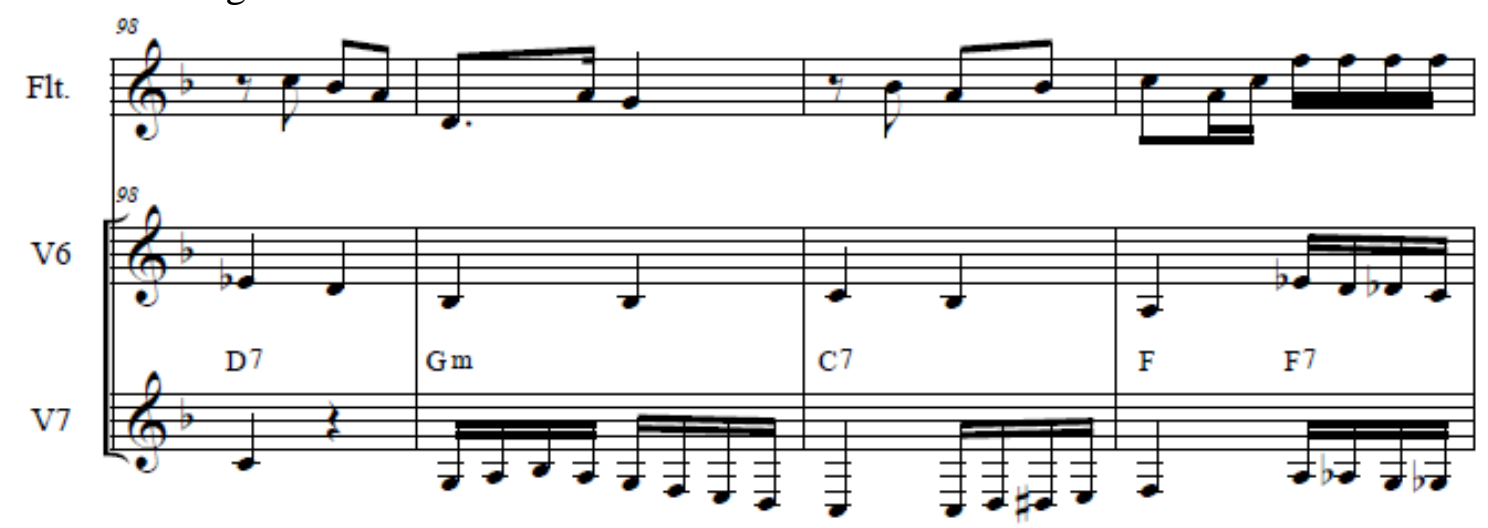

Fonte: Seu Lourenço no vinho, transcrição do autor. 
Neste exemplo, o V7 realiza D/C no compasso 98, ou seja, a terceira inversão de D7, e, portanto, está com o baixo na sétima. Neste caso específico, o diminuto é utilizado pelo V6 como se fosse a “quarta inversão” de D7 (D7/Eb), funcionando como uma terça exata de D/C. O segundo tempo do compasso 98 evidencia o fato de o acorde Ebdim estar sendo usado como o D7 apresentado, pois neste trecho o Ebdim se “desfaz” em D7, que seria o acorde original.

No entanto, ao contrário do que foi apresentado para a tonalidade menor, no caso da preparação para o acorde maior, as terças não se comportam de maneira análoga. Não existe um correspondente do acorde diminuto capaz de realizar as terças exatas. Ao procurar uma terça exata para o acorde $\mathrm{C} / \mathrm{Bb}$ o resultado seria algo como C/D ou C7/D. Essa sonoridade não corresponde à sonoridade típica de Choro, pois o resultado sonoro é um acorde de D9sus4 ou D9sus4(b13), ou seja, acordes com quantidade de tensão pouco usuais no estilo.

Figura 97 - C7/D

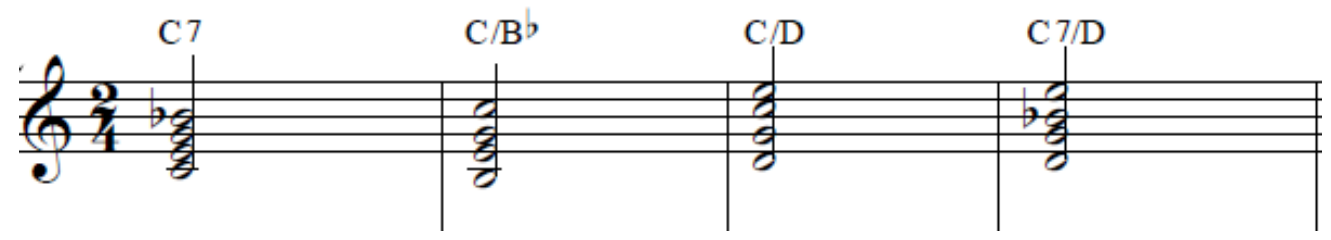

Fonte: Transcrição do autor.

A capacidade de realizar Inversões no contexto do Choro é, portanto, uma habilidade musical importante e complexa, seja quando realizada pelo V7, seja quando realizada pelo V6, dados os depoimentos apresentados nas entrevistas e dadas peculiaridades apresentadas nas análises.

No caso do V6, tal complexidade se eleva em função da sua condição de execução complementar ao V7. Além de dominar as Inversões, o V6 precisa saber qual Inversão utilizar a partir da performance do V7, gerando uma idiomática e específica teia de respostas. Portanto, observo, a partir das transcrições e análises realizadas, um conjunto muito específico de comportamentos do V6 em relação às Inversões no Choro, diferenciando-o de outros gêneros musicais.

5.4 BAIXARIAS. “Tocando em dueto com o V7”35

${ }^{35}$ CONTREIRAS, 2015, Entrevista, p.6. 
Na fala de Contreiras, se evidencia uma função importante do V6: o diálogo com o V7. Como visto na secção anterior, Inversões, a prática de realizar movimentos melódicos na região grave na música dita popular brasileira remonta, ao menos, ao Maxixe, através dos bombardinos, oficleides, tubas e trombones. Convém lembrar que tais movimentos melódicos não substituem a melodia - que continua a ser executada geralmente pelos instrumentos mais agudos - e apenas a valorizam, gerando uma espécie de baixo melódico, contraposto ao baixo puramente rítmico. Como explica Leme (2006, p. 76):

Funcionando como uma segunda melodia, a linha de baixo do choro, além de dialogar com a melodia principal define a harmonia conectando os acordes. É um tipo de linha muito ornamentada, com grande quantidade de notas, fazendo uso constante de semicolcheias e de tercinas, executada entre o C3 e o C1, e por isso soando bem em instrumentos que, como o violão e o bombardino, possuem nos registros médio-graves a sua melhor sonoridade. Este tipo de linha ficou conhecido como "baixaria do choro", ou apenas "baixaria".

Podemos apontar um paralelo entre o baixo no Choro e a Baixaria na música europeia no período barroco. Em uma análise um pouco mais sociológica, Otto Maria Carpeaux sugere que, no Barroco, o baixo pode ser encarado como a sustentação dada pelo povo ao monarca, representado pelo solista. Em suas palavras: “Os instrumentalistas que tocam o baixocontínuo representam o povo, ficando na sombra, mas apoiando o edifício que cairia sem seu trabalho incessante.” (CARPEAUX, 1999, p.60).

As Baixarias, assunto desta secção, guardam certa relação com a prática do período Barroco, pois normalmente são tratadas como contrapontos, na região grave do instrumento, que dialogam com a melodia. O professor e violonista Luiz Otávio Braga (2002, p.33) aponta o V7 como o contínuo na música popular: “A Baixaria do V7 é o elemento dinamizador das partes componentes do conjunto do Choro. É responsável, como na música barroca, pela continuidade na partitura, impulsionando as partes componentes (...) no tempo de seu transcurso".

O surgimento de tais contrapontos na região grave remete, no Brasil, às formações instrumentais relacionadas ao Maxixe, ao Samba e ao Choro, posto que tais gêneros de alguma forma se confundem em sua origem ${ }^{36}$. Segundo o pesquisador José Alexandre Leme

${ }^{36}$ O maxixe, o samba e o choro são três gêneros musicais que se misturam na sua origem e nas suas características musicais. Todos surgiram na cidade do Rio de Janeiro, durante a Primeira República, nas classes média e baixa, compostas por negros e afrodescendentes. Com instrumentação e padrões rítmicos de 
(2006, p.44), em importante pesquisa sobre o Baixo na música popular brasileira, tais formações foram: o piano solo, as bandas militares e os grupos de Choro.

No maxixe o baixo era bastante presente, possuía forte apelo melódico e contrapontístico e fazia uso constante de figuras rítmicas sincopadas. Era executado pelas tubas e bombardinos nas bandas militares e orquestras; pelos violões e oficlides nos grupos de choro; e muitas vezes apenas pelo piano, nas salas das casas de família e nos cafés.

No caso do piano, convém destacar a importância do instrumento como divulgador da Música, sobretudo no período anterior ao rádio e ao gramofone. (LEME, 2006).

Figura 98 - Baixaria no piano - exemplo 1.
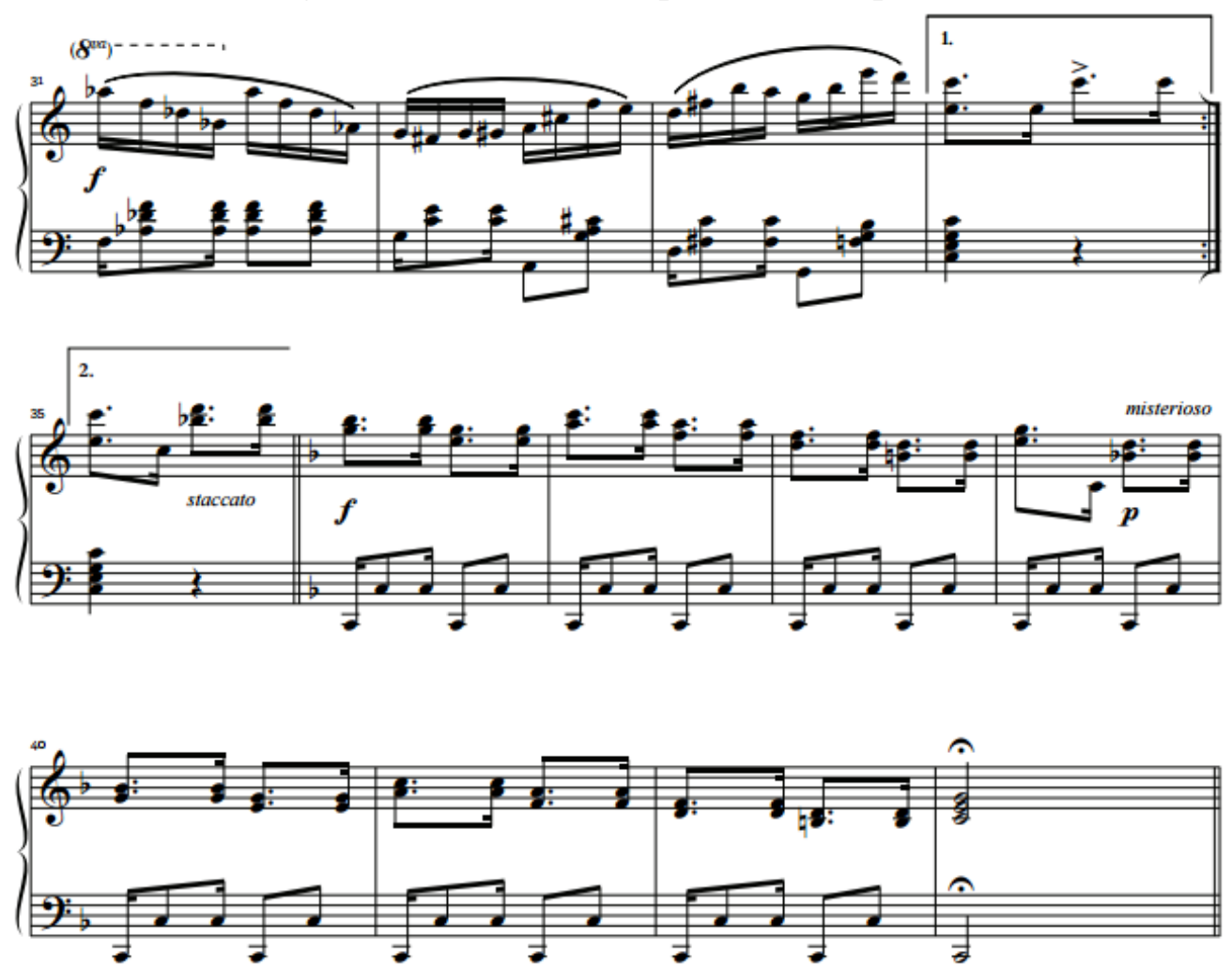

Fonte: Ernesto Nazareth, Atlântico, 1921.

A figura acima, com um trecho do Tango Atlântico de Ernesto Nazareth, ilustra um caminho de contraponto utilizado na mão esquerda do acompanhamento para piano, em que a célula rítmica, síncope +2 colcheias, fica amplamente caracterizada. 
O próximo exemplo, igualmente extraído do repertório de Ernesto Nazareth, reforça a utilização de contraponto no repertório de piano:

Figura 99 - Baixaria no piano - exemplo 2.
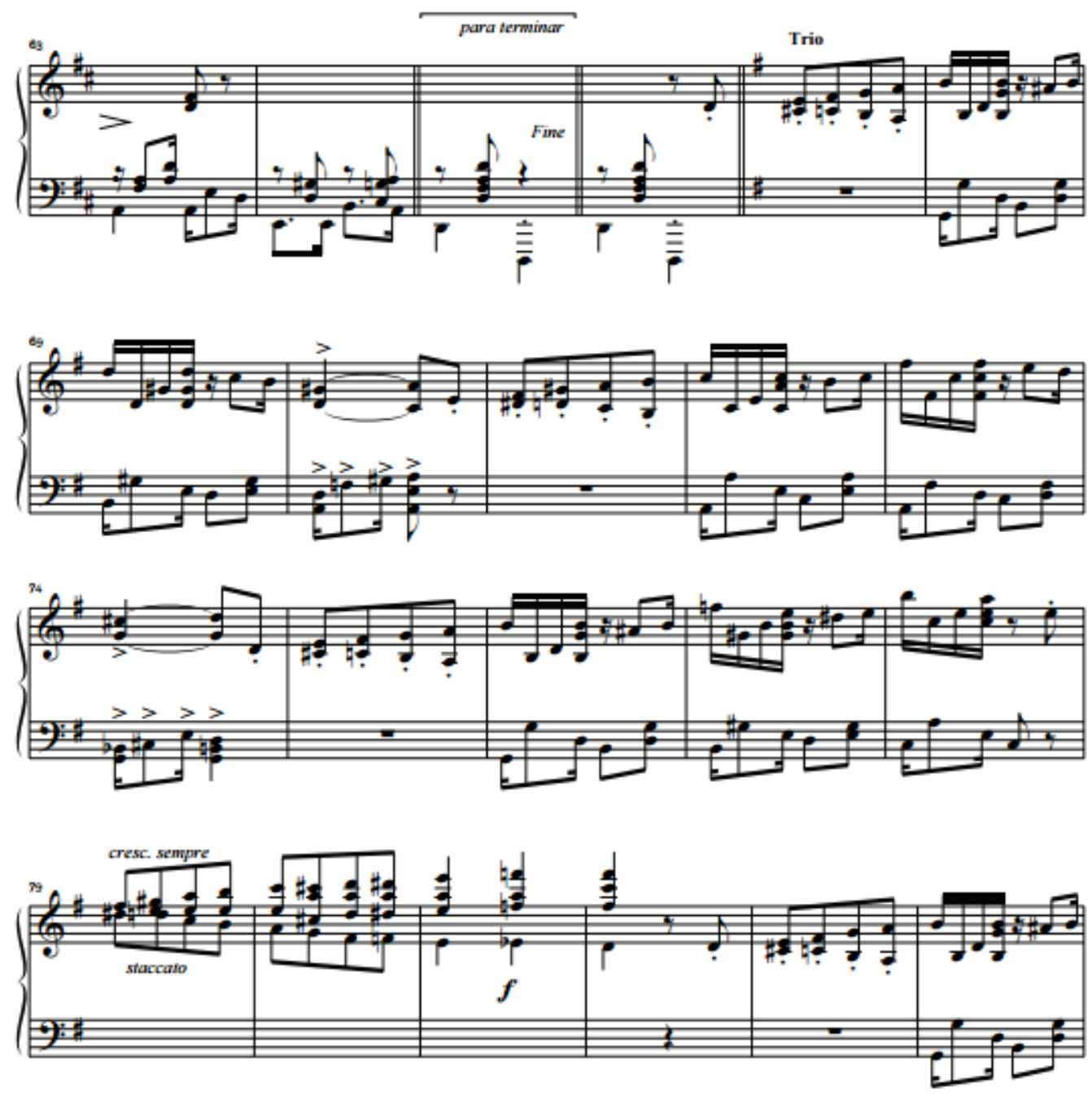

Fonte: Ernesto Nazareth, Tenebroso, 1913.

Na figura acima, o compasso 67 (quinto compasso da primeira linha) representa o início da parte C do Tango Tenebroso, dedicado ao violonista Sátiro Bilhar. A utilização dos contrapontos pode ser observada na mão esquerda, com a presença importante da figura rítmica com síncope +2 colcheias. Neste trecho, o contraponto pode ainda ser observado na mão direita, sobretudo nas vozes em sentido contrário presentes nos compassos 67, 71, 75, 79 e 80. Tais contrapontos viriam a ser aproveitados pelos violonistas na adaptação dessa peça ao regional. 
Em relação às bandas militares, Tinhorão (1998, p.187) destaca que as bandas militares “tiveram organização e vida precárias até à chegada do príncipe D. João com a corte portuguesa em 1808”, quando tais arregimentações puderam se estruturar de maneira mais eficaz, sobretudo após o aparecimento das bandas da Guarda Nacional, em 1830. A partir dessa estruturação, a música dos coretos proporcionada pelas bandas marciais passou a ser a principal oportunidade de audição de música instrumental para a maioria da população das grandes cidades brasileiras. Tinhorão chega a afirmar que: “a maior contribuição das bandas militares foi, inegavelmente, as criações do maxixe no Rio de janeiro e do frevo em Pernambuco” (1998, p. 191). Especificamente em relação à realização do baixo, Tinhorão aponta que "nas bandas militares o baixo era realizado pelos instrumentos de sopro como, trombones, tubas, bombardinos”. (TINHORÃO apud LEME, 2006, p.52). Leme destaca ainda o papel dos instrumentos de sopro graves para o desenvolvimento da baixaria. Ele afirma:

Realizando o baixo nas bandas militares tínhamos os instrumentos de metais graves, baixos e contrabaixos, que hoje são genericamente chamados de tuba, e os tambores: bombo e tambor surdo. O termo tuba foi utilizado pela primeira vez para um instrumento inventado na Alemanha em 1830. Desde então este nome passou a ser usado para vários instrumentos graves da família dos metais, entre eles: o sousafone, o helicon, o eufônio e o bombardão. (...) Por possuírem grande potência sonora, serem relativamente fáceis de tocar andando, e atuarem nos baixos e contrabaixos, as tubas são imprescindíveis nas bandas militares (LEME, 2006, p.59).

O exemplo abaixo, um arranjo de Pixinguinha a partir do original de Nazareth (para piano), ilustra a presença da Tuba como instrumento mais grave do contraponto, reforçada oitava acima pelo trombone e já com a companhia do sax barítono.

Figura 100 - Contraponto da Tuba. 


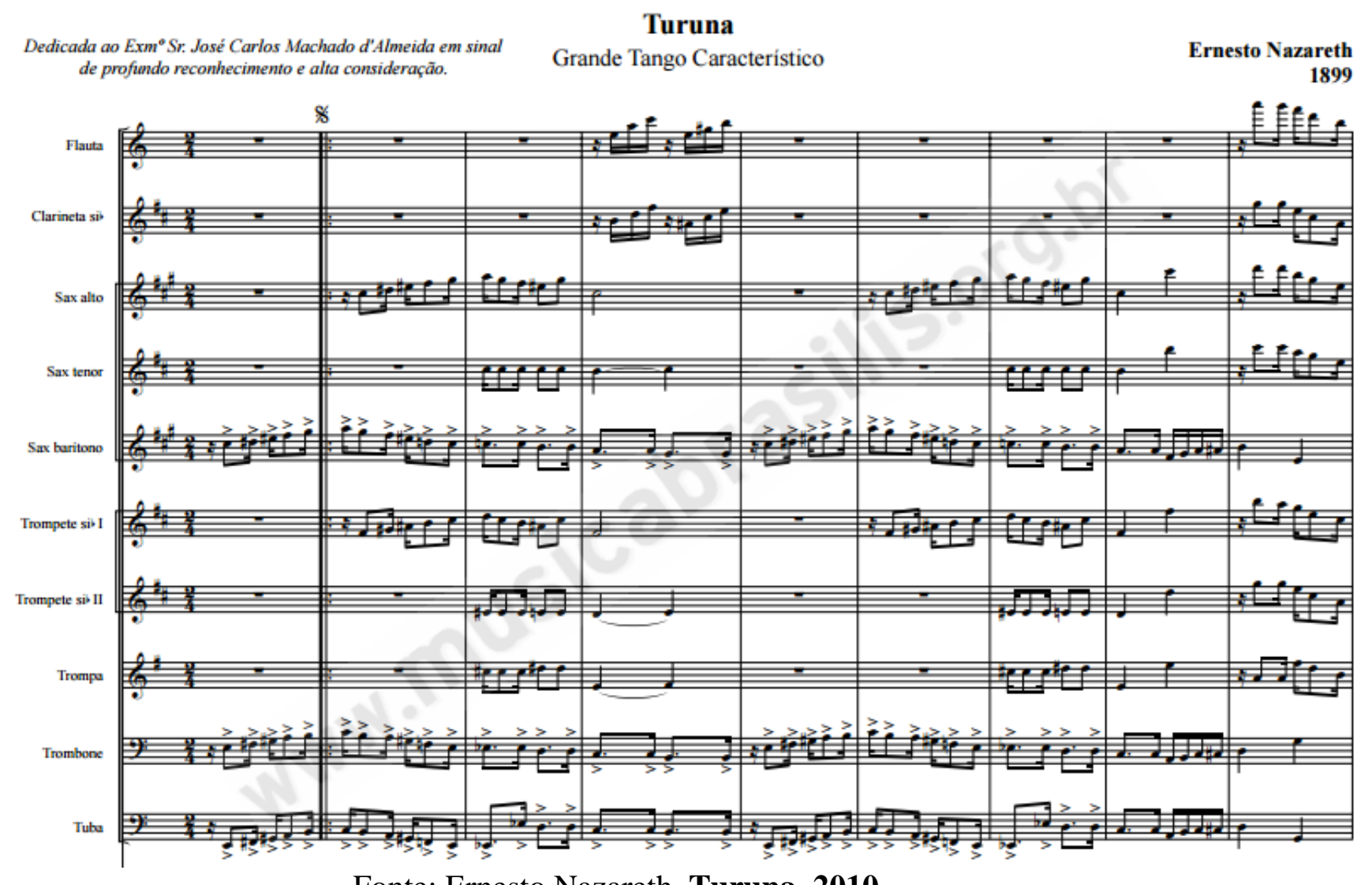

Fonte: Ernesto Nazareth, Turuna, 2010.

Finalmente, chego às formações de Choro. Livingston e Garcia, ao definirem as características do Choro, assim refletem sobre a função do baixo:

Uma característica marcante do estilo Choro é uma elaborada, geralmente improvisada, linha de baixo tocada nas cordas mais graves do V6 ou do V7. No Terno (Regional), é esperado que o violão forneça tanto um acompanhamento rítmico nos acordes quanto uma linha de baixo ${ }^{37}$. (LIVINGSTON; GARCIA, 2005, p. 6).

Cabe ressaltar que esta noção de contraponto não corresponde exatamente à noção erudita de contraponto, avalizada por rígidas regras de condução. Esta noção brasileira parece ter encontrado muito mais subterfúgios na experimentação prática do que nos compêndios.

Ian Guest (1996, p.95) define contraponto simplesmente como "uma melodia que soa bem com um canto dado”. Além disso, ele destaca o trabalho do baixo nesse contexto: “(...) o contraponto mais evidente é a linha do baixo da harmonia. (...) A linha do baixo é tão forte,

\footnotetext{
${ }^{37}$ A hallmark feature of Choro style is an elaborated, usually improvised, bass line played on the lower strings of the six- or seven-strings guitar. In the terno, the guitar is expected to provide both a chordal rhythmic accompaniment and a bass line.
} 
tão melodiosa que sugere, representa ou até substitui a harmonia”. Sève associa o contraponto ao violão:

Uma das maiores características da nossa música é a sofisticação do contraponto popular - que tem no V7 o seu principal representante, procurando conduzir linhas de baixo por movimentos adjacentes diatônicos ou cromáticos, além de desenhar de maneiras diversas grupos de síncopes e semicolcheias em escalas e arpejos. (SÈVE, 1999, p.18).

Dino 7 Cordas utiliza a palavra “contraponto” ao se referir à sua performance nas Baixarias: "Vou ouvindo os acordes e conduzindo a harmonia através dos baixos, do contraponto. (...) A melodia vai pedindo uma harmonia e eu vou conduzindo através do contraponto”. (DINO 7 CORDAS, 1992). Braga aponta ressalvas na concepção de contraponto e sugere uma diferenciação na terminologia:

O baixo poderá assumir o caráter de contraponto - não no estilo severo, palestriniano ou devedor a Fux - sujeitado à inventiva que é, por sua vez, diretamente dependente do conhecimento que se tiver do estilo. (...) Em geral, o estilo do Choro pressupõe um caráter polimelódico entre as partes envolvidas. Tal palavra se impõe melhor que o termo contrapontístico, que estaria mais sujeito à crítica da escola clássica formal. (BRAGA, 2002, p. 33).

Portanto, o contraponto popular brasileiro encerra especificidades que o diferenciam da concepção erudita. Nesse contexto, o músico Alfredo da Rocha Viana, o Pixinguinha, provavelmente tenha sido o músico que mais tenha contribuído para o desenvolvimento deste recurso no Choro, sobretudo quando migrou da flauta para o sax, na fase das gravações com o flautista Benedito Lacerda. Os contrapontos realizados por Pixinguinha nessa fase iriam influenciar irreversivelmente a performance do violão nesse estilo. Cabe ressaltar a importância dos aprendizados do jovem Pixinguinha na arte da segunda voz com o seu professor Irineu Batina (1863-1914). Segundo Pessoa:

Entre esses músicos frequentadores (da casa do pai de Pixinguinha), incluíase Irineu de Almeida, que tocava oficleide ${ }^{38}$ na banda de Anacleto e será

38 Sobre o oficleide, ou oficlide afirma-se que: "foi em 1916 que o Brasil ouviu pela última vez o som do oficleide, instrumento do mestre do então jovem Pixinguinha: Irineu de Almeida. Inventado em 1817, o oficleide só chegou ao Brasil em 1850, com a vinda das primeiras bandas de música. É considerado figura central para o desenvolvimento do choro. O instrumento conduzia os baixos, dando mais clareza à harmonia. Mais tarde, essa função foi assumida pelo violão de 7 cordas. Já no século XX, o oficleide chegou a ser o quarto instrumento mais usado no choro até se tornar extinto, sendo o maestro Irineu de Almeida o último grande músico a tocá-lo 
professor de Pixinguinha, a quem este atribuía os ensinamentos do contraponto que irão consagrá-lo nas gravações junto a Benedito Lacerda na década de 40 do século XX. Essa prática do contraponto presente nas bandas também aparecerá na gravação dos grupos de choros, função que será exercida pelo violão. (PESSOA, 2012, p.38).

Na figura seguinte é possível observar, no contraponto de Irineu de Almeida, a presença de semicolcheias e síncopes. Irineu é tido como o iniciador de Pixinguinha na música, e influenciaria também a sua relação com o contraponto.

Figura 101 - Contraponto do oficleide.

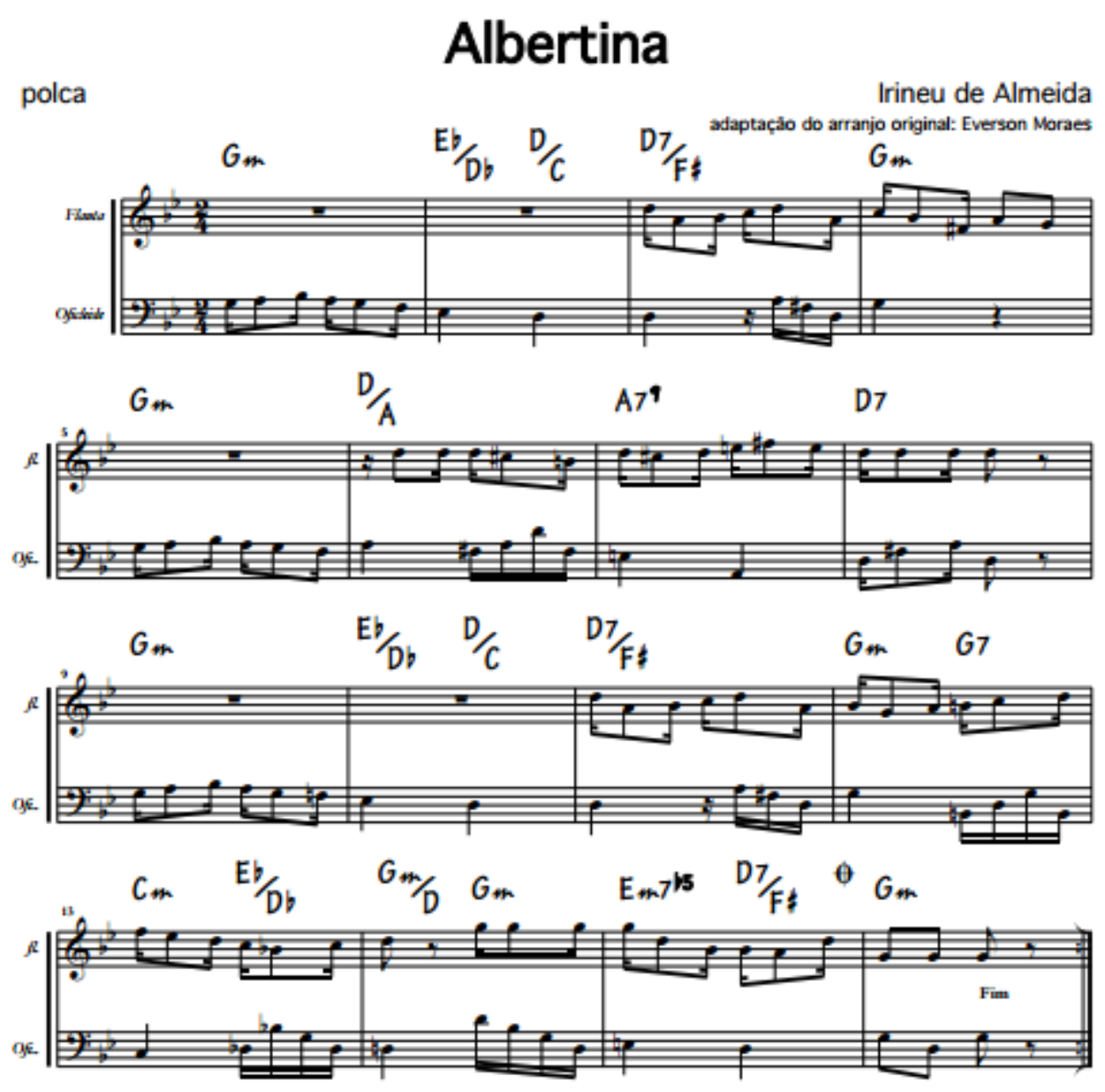

Fonte: Irineu de Almeida 100 anos depois ${ }^{39}$

no Brasil”. GRAVADORA BISCOITO FINO. Disponível em:

$<$ https://www.facebook.com/gravadorabiscoitofino?fref=photo>. Acesso em: fevereiro de 2016.

${ }^{39}$ MORAES, MORAES \& MIRANDA, p. 14. 
A genialidade contrapontística de Pixinguinha ficou registrada em muitas gravações em parceria com Benedito Lacerda, num total de 34 discos. O exemplo a seguir, Naquele Tempo, ilustra um pouco de sua habilidade com os contrapontos:

Figura 102 - Contraponto de Pixinguinha em Naquele Tempo.

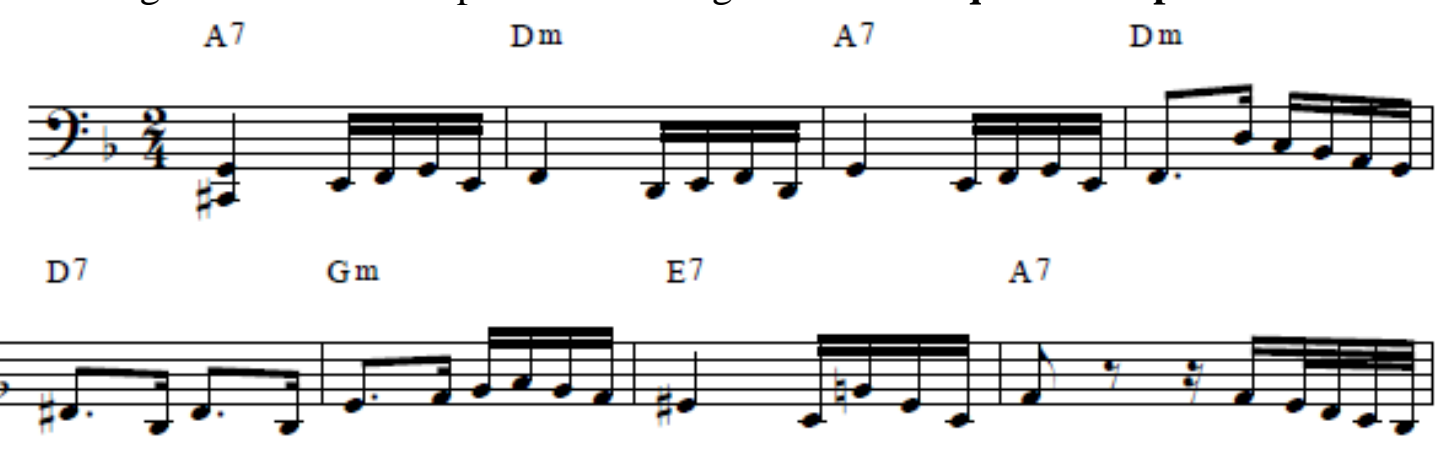

Fonte: Naquele tempo (Pixinguinha e Benedito Lacerda) - Duetos (SÉVE \& GANC, 1999, p.25).

O legado contrapontístico do mestre, por sua vez, ecoou vigorosamente nos violonistas de Choro. Segundo Braga (2002, p.34), para uma boa performance nas Baixarias é imprescindível "transcrever o saxofone tenor de Pixinguinha contraposto à flauta de Benedito Lacerda”. É facilmente possível observar a importância e a capilaridade de sua música por meio da análise da performance dos violonistas na gravação de Altamiro Carrilho do Choro Naquele tempo: 
Figura 103 - Baixarias dos violões
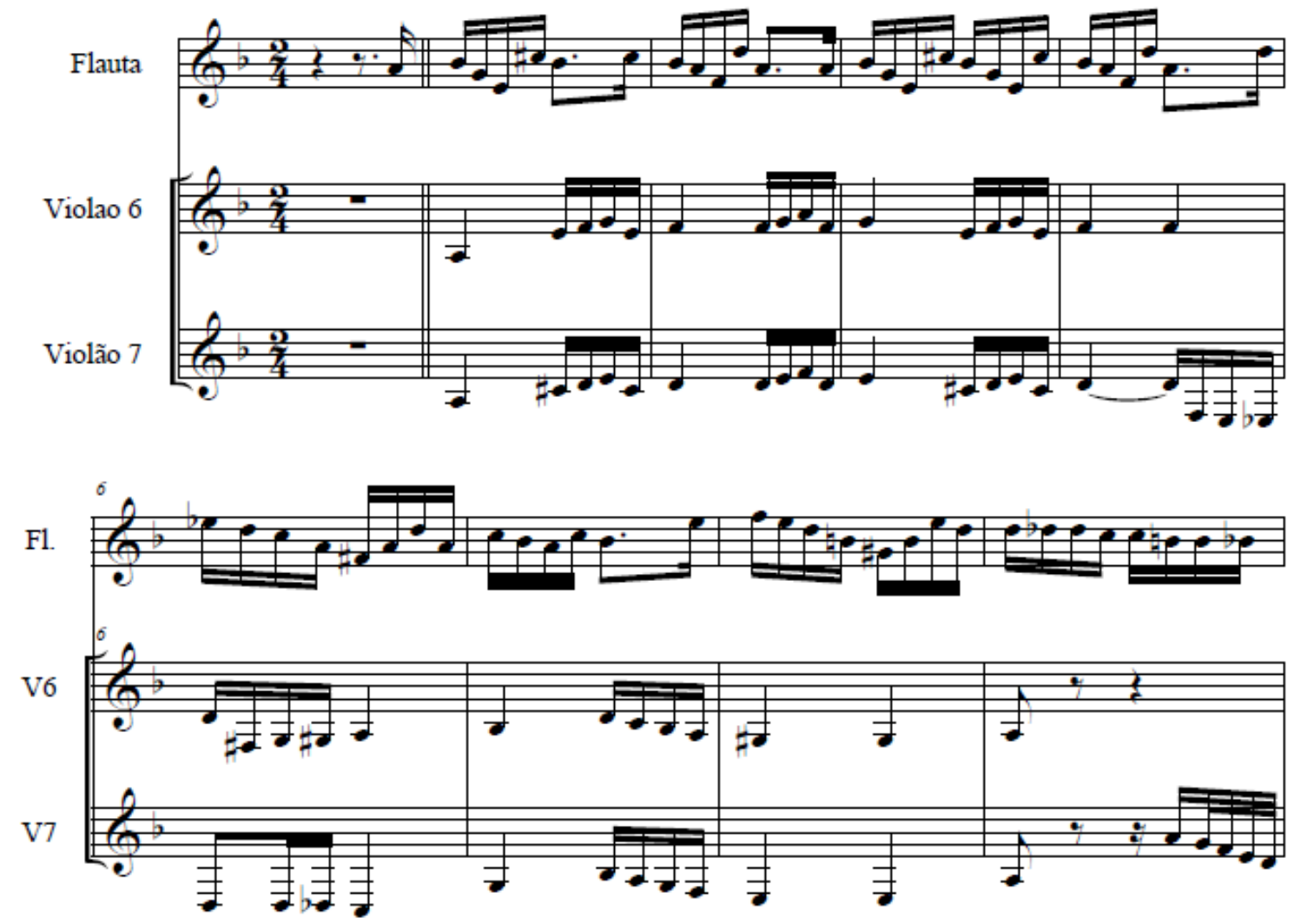

Fonte: Naquele tempo, transcrição do autor.

Na figura anterior é possível notar, para além da influência de Pixinguinha, uma citação direta ao seu contraponto na mesma música, exemplificado na figura 102. Restringindo a análise a uma rápida comparação entre os 4 primeiros compassos, é possível observar que o motivo rítmico (semínima no primeiro tempo e 4 semicolcheias no segundo tempo) utilizado por Pixinguinha é citado frequentemente pelos violonistas Dino e Meira. As notas dos compassos 2 e 4 utilizados por Pixinguinha correspondem às notas utilizadas pelo V6 nos respectivos compassos. As notas utilizadas por Pixinguinha no compasso 3 correspondem às notas do V7. O V7 recorre também à frase de Pixinguinha no compasso 9.

O desenvolvimento desta linguagem, portanto, gerou as Baixarias. Os baixos melódicos se tornaram então característica marcante e obrigatória nas formações de Choro (BECKER, 1996). Segundo Livingston e Garcia, os "riffs cadenciais, ou terminações padronizados são uma característica de identificação importante de estilo Choro” ${ }^{40}$. Portanto, um dos traços mais marcantes na performance do violão de Choro é a realização das Baixarias

\footnotetext{
${ }^{40}$ Cadential riffs, or standardized endings are an important identifying feature of Choro style. (LIVINGSTON; GARCIA, 2005, p.7
} 
e geralmente cabe ao V7 a responsabilidade maior sobre a realização destas. Como afirma Leme, o V7 se tornou fundamental no Choro:

Instrumento muito importante no choro, o violão sete cordas consiste em um violão padrão acrescido de uma sétima corda mais grave, que pode ser afinada em dó ou em si duas oitavas abaixo do C3. Com esta tessitura estendida para os graves os violonistas conseguiam realizar melhor as "Baixarias", tão importantes para o choro, e que normalmente eram realizadas pelo oficlide e num segundo momento pelo saxofone tenor. (LEME, 2006, p.54).

Becker ressalta a consolidação da Baixaria a partir do desenvolvimento do V7 - que atingirá seu ápice com Dino 7 cordas - mas destaca o pioneirismo do V6 nessa prática. Nas palavras de Becker (1996, p.88):

Com a inclusão do Violão de 7 cordas nos grupos de Choro (...) a função da baixaria ficou ainda mais definida. (...) Entretanto foi com Horondino José da Silva, o Dino 7 cordas, que as baixarias chegaram ao ápice, com a utilização de frases virtuosísticas (...). Vale ressaltar que a ideia de um violão realizando as baixarias não surgiu a partir do Violão de 7 cordas. O que aconteceu foi exatamente o contrário, surgindo a sétima corda como uma ampliação do campo das possibilidades fraseológicas do instrumento.

Portanto, é interessante observar, que antes da adição da sétima corda, o V6 já executava a Baixaria. Historicamente, Livingston e Garcia apontam 1914 como o ano da realização da primeira gravação em que se podem ouvir Baixarias realizadas pelos violões. Segundo os autores:

A mais antiga gravação que exibem tais características datam de 1914: a valsa "Falena", de Chiquinha Gonzaga, gravada na Casa Edison por Chiquinha Gonzaga e Seu Conjunto, no qual os violões exibem uma linha de baixo proeminente com passagens descendentes escalares entre graves típicas do Choro $^{41}$. (LIVINGSTON; GARCIA, 2005, p.7).

Pessoa sugere o ano de 1907 como o embrião desse processo, data em que os grupos Novo Cordão e Cavaquinho de Ouro levam para o mercado fonográfico a formação típica dos ternos regionais, com violão e cavaquinho acompanhando o instrumento solista:

Nessas primeiras gravações, já aparecem alguns elementos da linguagem do choro, como em Doralice, gravada pelo grupo Novo Cordão, em que é

\footnotetext{
41 The earliest recording that exhibit that characteristic dates from 1914: the waltz "Falena" by Chiquinha Gonzaga recorded for Casa Edison by Chiquinha Gonzaga e seu Conjunto, in which the guitars exhibits a prominent bass line with stepwise descending scalar passages between bass notes typical of Choro style.
} 
possível encontrar o violão esboçando frases contrapontísticas de ligação de harmonia na região grave e modulações. (...) Em relação ao violão já vislumbra a ideia de condução rítmica, caminhando pelas inversões de acordes e com algumas ligações de colcheias entre o segundo tempo e o primeiro tempo do próximo compasso e, em alguns momentos, até frase com quatro semicolcheias. (PESSOA, 2012, p.14).

Naturalmente, os primeiros violonistas a adotarem a prática contrapontística o faziam com menos recursos técnicos, valendo-se das Inversões e de algumas poucas notas de ligação entre os acordes. Esta prática, relacionada a um baixo um pouco mais rítmico e menos melódico, é conhecida no ambiente do Choro como “Violão pé-de-boi”. Segundo Cidinho 7 Cordas (2015, E, p. 24), o “pé-de-boi” é aquele violonista que só faz a marcação dos baixos tal como o Tute fazia”.

Tute, por sinal, (juntamente com China, irmão de Pixinguinha) foi um dos primeiros violonistas de que se tem notícia a utilizar a sétima corda. Na introdução do livro sobre o V7 do violonista Rogério Caetano, o violonista Marco Pereira aponta que: “Arthur de Souza Nascimento (1886-1957), o Tute, foi o mais notável sete cordas de seu tempo, e um dos primeiros (...) a se servir dele de forma eficaz. Tute definiu a afinação da sétima corda (dó) e influenciou diversos violonistas de sua época”. (CAETANO, 2010, p.6). No entanto, com o afastamento de Tute do mundo profissional, Horondino José da Silva (1918-2006) passou a utilizar o instrumento em 1952 - que o rebatizaria como Dino 7 Cordas - e elevou o patamar do instrumento na música brasileira, nas palavras de Caetano: "Dino desenvolveu suas ideias no V7 e fixou, de forma brilhante e definitiva, a linguagem do seu instrumento”. (CAETANO, 2010, p.7).

Nessa perspectiva, o V7 lança mão de uma quantidade grande de recursos para realizar a Baixaria. Livingston e Garcia definem essa performance, apontando as habilidades de condução de vozes e de improvisação exigidas do violonista que executa o V7:

A linha de baixo, ou Baixaria, é criada usando uma série de recursos estilísticos: realizando o fill entre acordes tônicos e acordes dominantes com escalas, utilizando um walking bass (ou seja, o movimento gradual reforço do ritmo), inserindo respostas melódico-rítmicas ao solista ou cavaquinho, improvisando melodias contrapontísticas, utilizando clichês e baixospedais $^{42}$. (LIVINGSTON; GARCIA, 2005, p. 6).

\footnotetext{
${ }^{42}$ The bass line, or baixaria (from baixo, bass), is created using a number of stylistic resources: filling in the tonic and dominant chords with scalar runs, utilizing a walking bass (i.e. stepwise motion reinforcing the beat), inserting a melodic rhythmic responses to the soloist or cavaquinho player, and improvising contrapuntal melodies, riffs, and pedal points.
} 
Para realizar as Baixarias por meio desses recursos, os violonistas normalmente utilizam a dedeira, uma ferramenta normalmente construída de metal ou acrílico utilizada no dedo polegar que permite maior vigor na realização das Baixarias, sobretudo, nos casos em que se utilizam cordas de aço. Para Caetano, a dedeira tem uma função técnica e expressiva:

Com intuito de se obter maior volume, como também um timbre mais definido e de maior projeção, utiliza-se a dedeira (...). O movimento do polegar com a dedeira é sempre realizado de cima pra baixo, geralmente apoiando na corda imediata inferior à corda ferida. Os movimentos são enérgicos utilizando não só a articulação do polegar, como também o peso do braço direito para se obter a sonoridade característica do instrumento. (CAETANO, 2010, p.10).

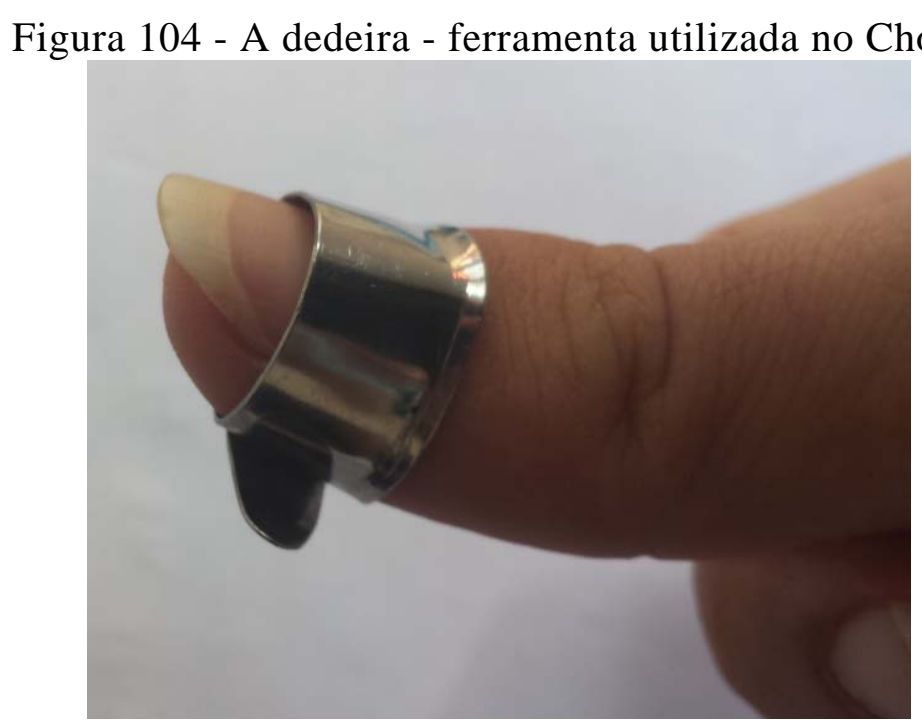

Fonte: Foto do autor.

Via de regra, portanto, a dedeira tem a função de conferir velocidade e força (volume) na execução das Baixarias. No ambiente de uma Roda de Choro sem amplificação, a dedeira se torna ferramenta indispensável.

No entanto, convém destacar que atualmente alguns violonistas, sobretudo a partir da popularização das cordas de nylon, não usam dedeira. Além disso, mesmo aqueles que a usam precisam desenvolver técnica de fraseado em outros dedos além do polegar, como ressalta Augusto Contreiras:

(...) é preciso aperfeiçoar as técnicas de solo, pois, os duetos atualmente não envolvem apenas o uso da dedeira (dependendo do violonista, pois alguns violonistas não a usam), mas o trabalho de baixo nas cordas agudas, 
facilitados pelo uso dos dedos anelar, médio e indicador, o que exige estudo apurado. (CONTREIRAS, 2015, E., p.6).

Convém também ressaltar a preferência dos chorões pela utilização das cordas soltas quando é possível. O uso das cordas soltas confere velocidade à frase e constitui parte importante da timbragem do violão de Choro. Segundo Cidinho 7 Cordas (2015, E., p.28), este recurso confere ainda facilidade na execução: “Creio ser mais fácil com cordas soltas do que com cordas presas”.

Na secção seguinte, apresento a análise técnica das Baixarias, sobretudo no que diz respeito aos diálogos entre V7 e V6.

\subsubsection{A trama - um assunto grave}

Os violões

vão tecendo a fazenda Com tramas de renda Feito um trancelim.

(Roda de Choro, PAULO CÉSAR PINHEIRO)

Como o V7 possui uma corda mais grave que o V6, recai sobre ele uma ascendência maior pela execução das Baixarias. No entanto, em diversos momentos cabe ao V6 a complexa missão de responder a essas Baixarias do V7, realizando, de forma simultânea, Baixarias complementares. Essas respostas, típicas dos regionais de Choro, normalmente são chamadas de "Duetos” com o V7 ou de "Terças da Baixaria”. Como consequência do fato de que as respostas do V6 nem sempre serem “Terças”, opto pelo termo "Dueto" ao referir às baixarias complementares. Os Duetos são, portanto, os entrelaçados diálogos de contrapontos graves realizados pelos violões no Choro.

Convém lembrar que o V6 nem sempre responde às baixarias do V7, como ficou explicito nos depoimentos. O violonista Augusto Contreiras aponta que o V6 precisa "fazer os baixos em dueto, mas não de forma exagerada, com o V7”. (CONTREIRAS, 2015, E. p. 7). Rafael dos Anjos assinala que “outra habilidade é tocar em dueto com o V7. Não todas as frases que ele faz obviamente, mas algumas combinadas pelos violonistas e os baixos de obrigação que existem em quase todos os choros”. (ANJOS, 2015, E., p.31). Diante das falas dos violonistas entrevistados, pode-se concluir que além de saber COMO gerar respostas ao 
V7, o V6 precisa saber também QUANDO gerar tais respostas, conhecimento que também faz parte da complexa e idiomática performance.

No caso em que a situação exige uma resposta, o violonista de 6 cordas precisa, para planejá-la, saber reconhecer a baixaria do V7. Ou seja, o violonista de 6 cordas, em tese, precisa conhecer profundamente a performance do violonista de 7 cordas. De maneira até mais ampla, o violonista Fernando César (2015, E., p. 26) aponta que o músico "vai ter que ter tocado o primeiro violão (V7) pra conseguir fazer o segundo violão (V6)”, reforçando a ideia da complexidade técnica envolvida na performance do V6.

A respeito do entrosamento entre V7 e V6, Bittar aponta que:

Meira se tornou um especialista em perceber os momentos em que Dino
realizava tais frases e, com um reflexo apurado, executava de bossa as terças
dessas baixarias. Jorginho do Pandeiro, irmão de Dino, que tocou durante
anos com Meira no Regional do Canhoto, nos disse em entrevista que o
entrosamento do trio de cordas do conjunto era um fator diferencial, como
mostra o trecho extraído da entrevista: “Um conhecia muito bem o outro. O
Dino fazia um baixo, o Meira já fazia a terça, ajudava ele. (...) Hoje em dia o
pessoal tem que ensaiar pra fazer terça. Ali não, o Dino fazia um baixo o
Meira já ia logo com a terça (...) ele ouvia o que o Dino ia fazer e começava
da segunda nota. Tinha um ouvido bárbaro”. (Entrevista com Jorginho do
Pandeiro concedida ao autor no dia 07/05/2010). (BITTAR, 2011, p.80).

Em uma bem-humorada alusão à velocidade de pensamento necessária à execução da Terça, o músico Valério de Sousa assim descreve o violonista Damázio, expoente do V6 no Choro: “(...) e por falar em terças não posso deixar de lembras do meu saudoso amigo Damázio Batista que era um expert. Se você espirrasse ele fazia uma terça na hora...” (SOUSA, 2015, E., p. 36).

Portanto, conhecida a Baixaria “original” do V7, o violonista de 6 cordas precisa planejar sua resposta. Segundo Braga: “A formação de baixos em terceiras ou sextas a dois violões é uma característica marcante do Choro tradicional”. (BRAGA, 2002, p.34). Além das respostas em terças e sextas citadas, as Baixarias a serem respondidas podem vir também em forma de uníssono ou oitava.

No caso dos baixos em uníssono, a proposta é um simples reforço da voz principal. É o que ilustra o exemplo abaixo, transcrito da apresentação de Déo Rian e o grupo Época de Ouro no programa Ensaio (TV Cultura). Na faixa Tenebroso, a parte A é constituída somente de Baixaria, de acordo com o original para piano de Ernesto Nazareth: 
Figura 105 - Baixaria como melodia.

Ao bom e wilhe amigo Satyo Bulbar

Tenebroso

tango

Ernesto Nazareth

1913
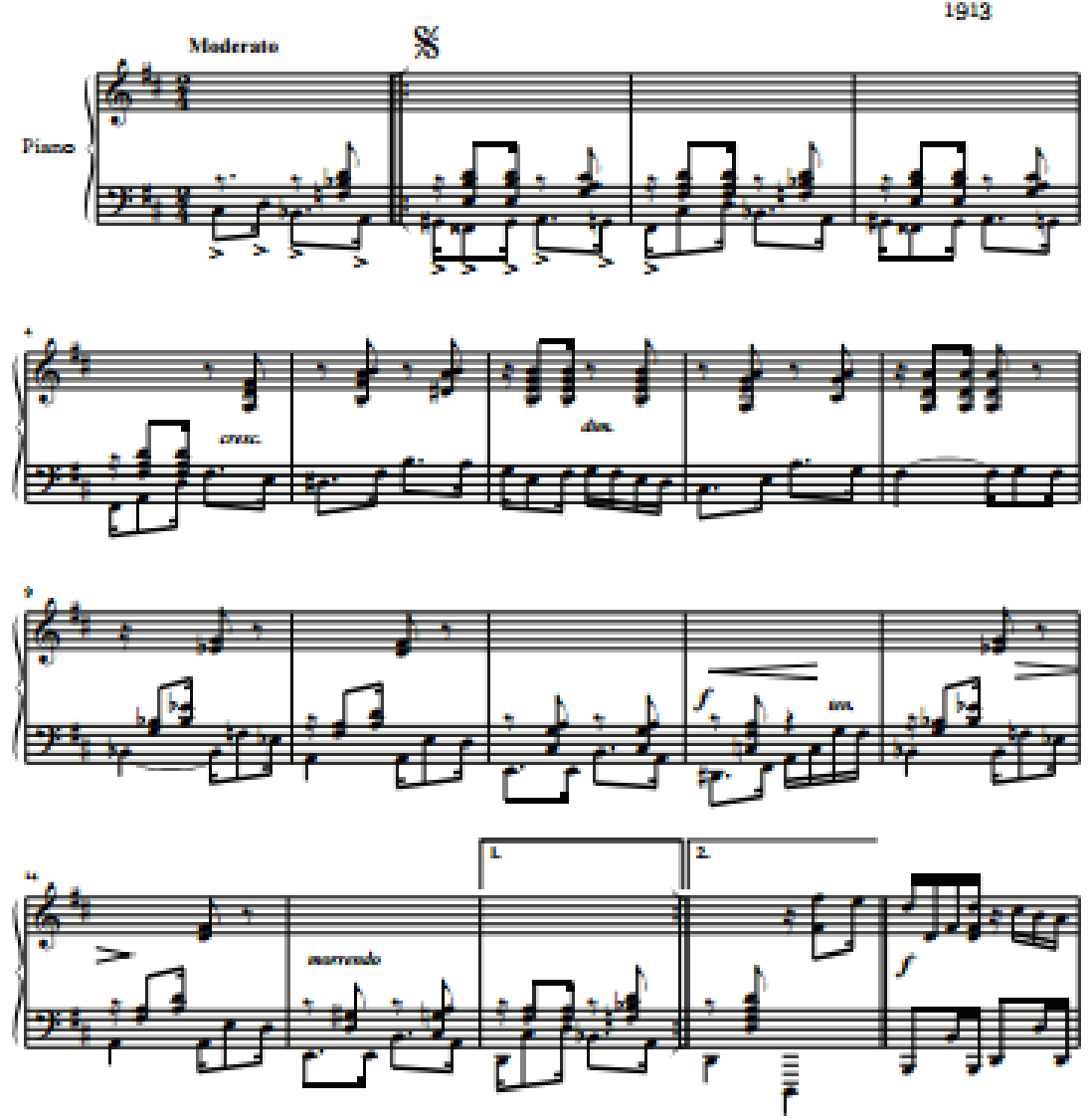

Fonte: Ernesto Nazareth, Tenebroso, 1913.

Na apresentação do grupo Época de Ouro no programa Ensaio, a Baixaria realizada é exatamente a mesma, e acaba por constituir a melodia da parte A. Interessante notar que 3 violões - representados por Dino 7 Cordas (V7), Damásio (V6) e César Faria (V6) - realizam a frase citada em uníssono.

No entanto, mais frequentemente, a resposta do V6 será uma resposta uma terça ACIMA da baixaria original (V7). É possível notar que no repertório das frases do V7 
figuram clichês, baixos de obrigação ${ }^{43}$ e improviso. Um dos clichês mais recorrentes é a própria escala, normalmente utilizada de forma descendente, como apresentado na figura a seguir:

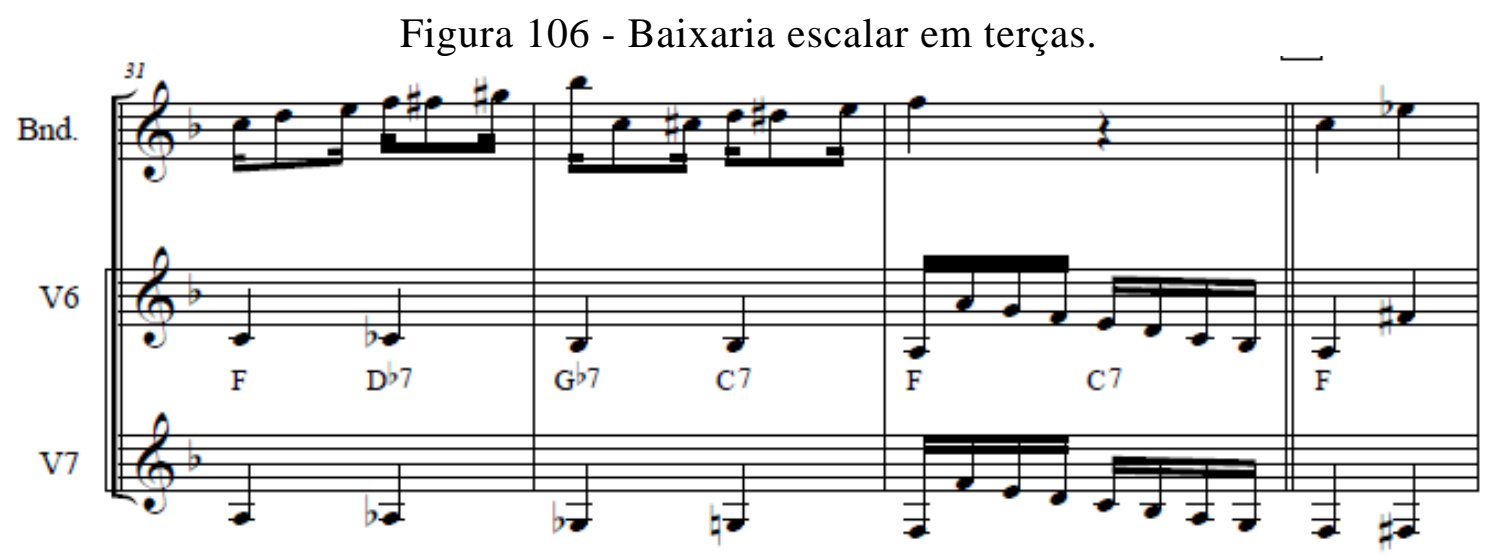

Fonte: Chorinho na Praia, transcrição do autor.

Nesta tradicional abertura ou finalização de partes, o V7 pode realizar a escala da tonalidade sobre o I, sobre o $\mathrm{V}$ ou sobre ambos, como podemos observar no compasso 33. No exemplo apresentado, o V6, executado pelo violonista Damázio Batista, acima citado, se comporta em terças exatas, ou seja, cada nota do V6 (lá, sol, fá, mi, ré, dó, sib, lá) é a terça da nota do V7 (fá, mi, ré, dó, si, lá, sol, fá), dentro da tonalidade de F, e o V6 finaliza o trecho também em terças, com F/A sobre o F do V7. As notas tocadas pelo V6, terças do modo jônio de F tocadas pelo V7, configuram o modo frígio de Am. Portanto, sobre os acordes maiores ou na preparação para eles - pode ocorrer a predominância da “ambiência” do modo jônio nas baixarias escalares do V7, e uma consequente predominância do modo frígio nas respostas do V6, localizadas uma terça diatônica acima.

Em relação aos acordes menores - ou nas preparações para eles - podemos observar a predominância da ambiência da escala menor harmônica sobre as outras escalas menores nas Baixarias. Naturalmente, essa tendência se estende ao V6.

Figura 107 - Escala Dm harmônica no V7 e terças correspondentes no V6.

43 Obrigações: “são frases melódicas corriqueiramente consagradas por arranjos ou que são inerentes à composição original” (BRAGA, 2002, 35). 


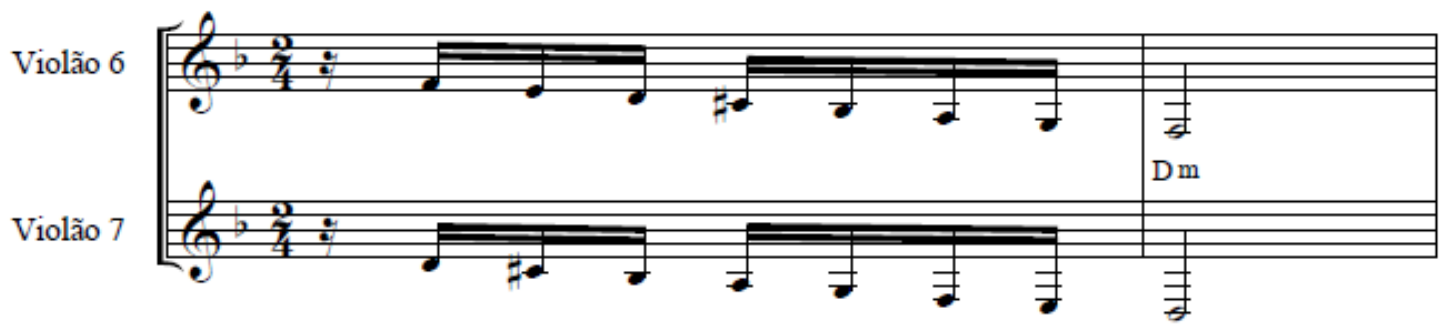

Fonte: transcrição do autor.

A próxima figura representa o compasso 120 da gravação de Enigmático. Podemos notar a utilização da 7M (fá \#) pelo V7, configurando a escala de Gm harmônica.

Figura 108 - Baixaria utilizando a escala menor harmônica - exemplo1.

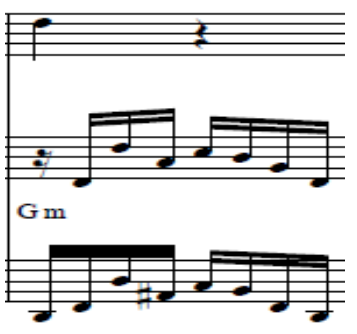

Fonte: Enigmático, transcrição do autor.

Neste caso, a escala menor harmônica é utilizada sobre o acorde menor. No exemplo a seguir é possível observar a utilização da escala menor harmônica sobre a preparação para um acorde menor, em dois momentos distintos:

Figura 109 - Baixaria utilizando escala menor harmônica - exemplo 2. 

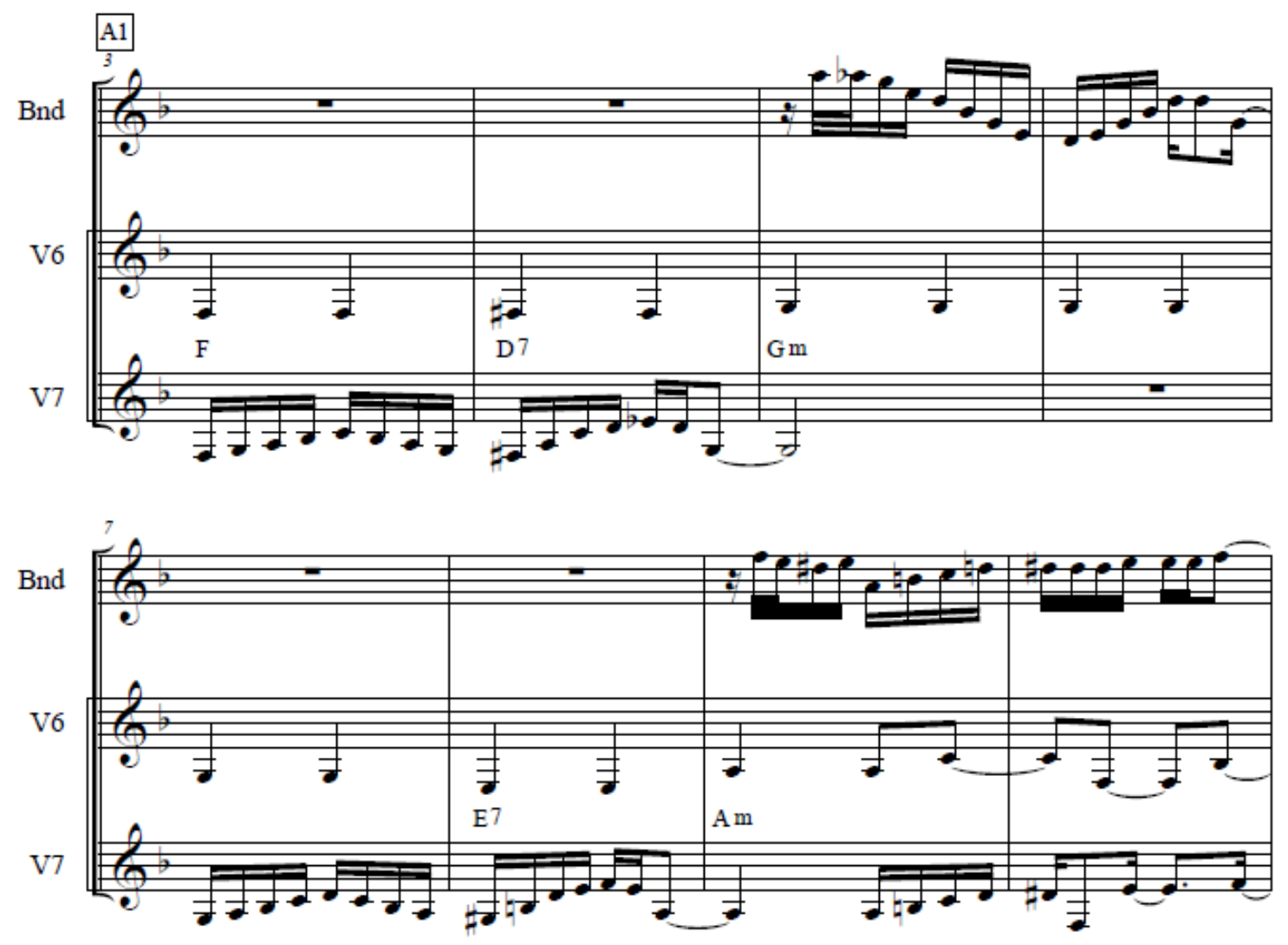

Fonte: Arabiando, transcrição do autor.

Na figura anterior, é possível notar a utilização da escala menor harmônica de Gm sobre a sua preparação (D7) no compasso 4. A menor harmônica fica configurada a partir da execução da 7M (fá\#) e da 6m (mib). A escala de Gm harmônica também pode ser lida como a escala mixolídea (b9) (b13) de D. A figura 109 (Arabiando) indica ainda comportamento análogo no compasso 8, onde a escala de Am harmônica é utilizada sobre o acorde de E7, preparatório do acorde de Am.

Figura 110 - Baixaria utilizando a escala menor harmônica - exemplo 3.

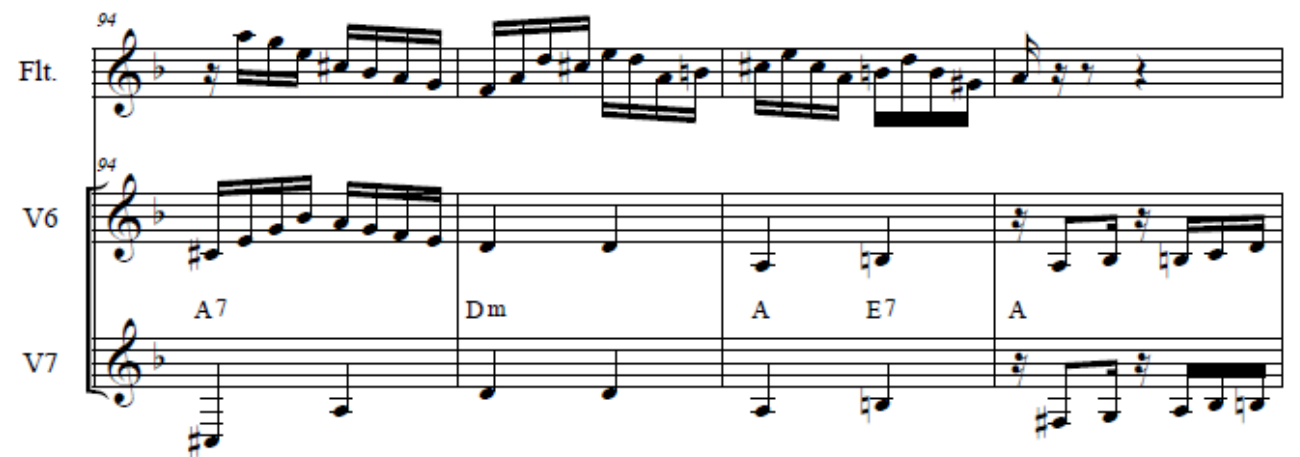

Fonte: Seu Lourenço no vinho, transcrição do autor. 
Na figura acima, é possível observar novamente, no compasso 94, a utilização da escala menor harmônica na preparação de um acorde menor (Dm), ou seja, sobre o seu dominante A7. Neste caso, de maneira semelhante aos dois exemplos anteriores, a escala de Dm harmônica pode ser vista também como a escala mixolídia (b9)(b13) de A. Interessante notar que no trecho do exemplo anterior a Baixaria é realizada prioritariamente pelo V6. A esse respeito, convém destacar o depoimento do violonista Fernando César (2015, E. p.27):

Sobre o papel do V6, engana-se quem acha que ele está ali só pra fazer a terça, ou a quinta. O V6 já foi o violão principal do Choro. Isso vemos em vários regionais, como Benedito e César Faria, dois violões de 6 cordas. Waldir também gravou com Jorge Santos e outro V6 - com o V6 com função de primeiro violão. Ele (V6) junto com o V7, ele pode fazer os baixos em terças, em quintas, em uníssono, em oitavas, (...) ele também poder fazer baixos como o próprio V7, em momentos diferentes. Seriam dois violões cumprindo a função de primeiro violão, mas em momentos diferentes - em determinados momentos específicos - assim como fez muito bem o Damásio.

Portanto, o V6 assume, muitas vezes, uma espécie de protagonismo na performance. Quanto à realização das baixarias, a ocorrência da escala menor harmônica sobre acordes menores, observadas anteriormente, é expressiva, sobretudo na preparação para estes. No entanto, em alguns casos é possível observar a utilização da escala menor primitiva, da escala dórica e até mesmo da escala menor melódica sobre o acorde menor, a depender da função desse acorde no contexto harmônico.

Figura 111 - Baixaria em terça utilizando a escala menor primitiva - exemplo 1.

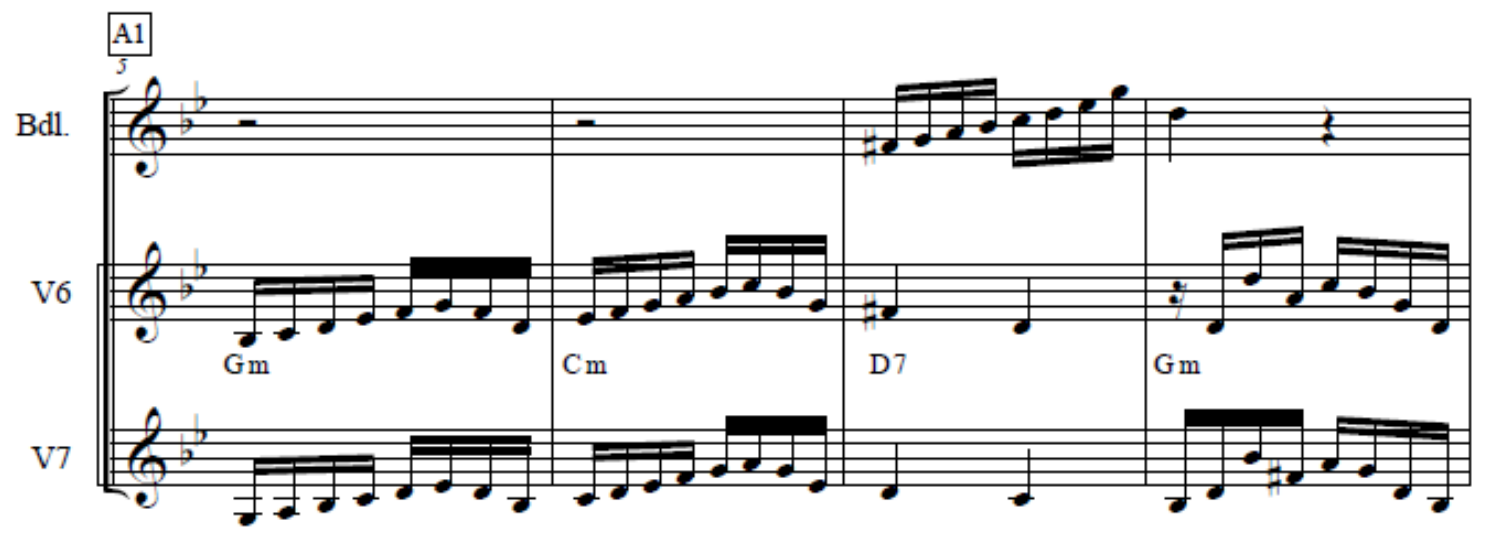

Fonte: Enigmático, transcrição do autor.

Na figura acima seria difícil precisar qual é a escala menor sobre o compasso de Gm (compasso 5) caso nos limitássemos à perspectiva de análise do V7. Como este não executa a 
sétima da escala (a nota fá), ficaríamos na dúvida entre a menor primitiva e a menor harmônica, uma vez que a menor melódica está descartada pela utilização da 6m (a nota mi bemol). No entanto, podemos dirimir esta dúvida a partir da observação geral do dueto dos violões. A execução em terças do V6 confirma que se trata de um ambiente da escala menor primitiva uma vez que o V6 executa a m7 (a nota fá) neste mesmo compasso. Importante notar que esta ocorrência se dá sobre um acorde menor com função tônica, a caminho do IV.

Figura 112 - Baixaria em terças utilizando a escala menor primitiva - exemplo 2.

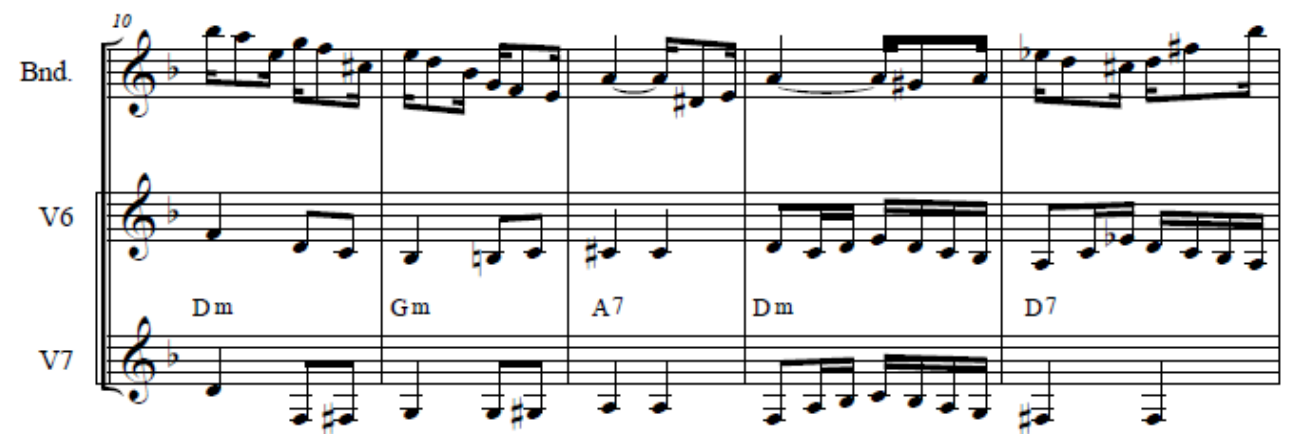

Fonte: Chorinho na praia, transcrição do autor.

Na figura anterior é possível perceber, novamente, o comportamento complementar, o dueto em terças do V6 nos compassos 11, 12 e 13. No início do compasso 11, V7 e V6 estão repousados, respectivamente, nas notas sol e sib, em um intervalo de terça. Então eles seguem em terças neste compasso e no próximo, onde tocam lá e dó\#, respectivamente. No compasso 13, os violões executam um trecho mais denso, sempre em terças, e também em terças chegam ao início do compasso 14, com V7 em fá\# e V6 em lá, sobre o acorde de D7. Novamente, a utilização da escala menor primitiva sobre o acorde menor com função tônica é observada no compasso 13. Tanto V7 como V6 utilizam a m6 (sib) e a m7 (dó natural), confirmando a escala menor primitiva. Interessante notar que no segundo tempo do compasso 11 o V6 executa a nota si natural sobre o acorde de Gm, ou seja, uma terça maior em um acorde menor. Tal utilização é justificada pelo caráter cromático da frase, que pretende complementar a frase do V7, também cromática nesse compasso.

Portanto, até agora, os exemplos musicais transcritos destacam a ocorrência da escala harmônica (principalmente para acordes com função tônica e dominantes de acordes menores) e a ocorrência da escala menor primitiva (para acordes menores com função tônica). Em contextos diferentes destes, sobretudo para acordes ligados à função subdominante, é possível observar uma importante ocorrência da escala dórica. 
Figura 113 - Baixaria em terça utilizando a escala dórica - exemplo1.

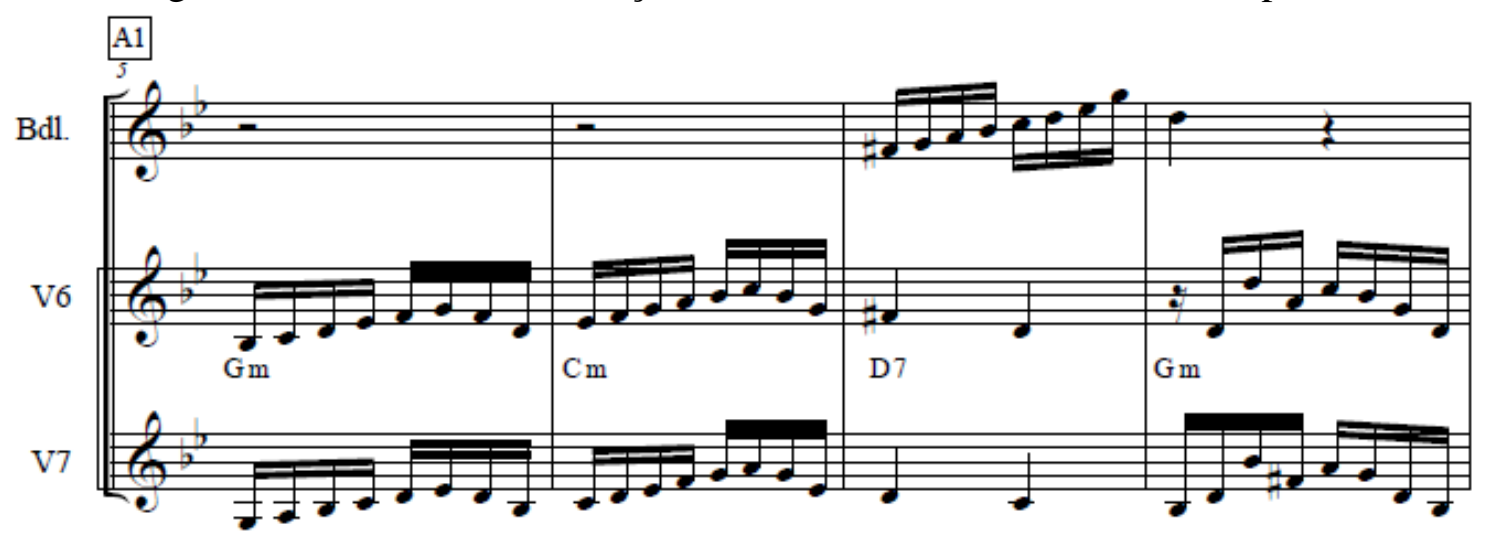

Fonte: Enigmático, transcrição do autor.

Na figura 109, idêntica à figura 107, é possível observar a ocorrência da escala dórica sobre o acorde menor. No compasso 6, sobre o acorde de $\mathrm{Cm}$, nota-se a ocorrência das mesmas notas do compasso anterior (Gm primitiva), porém agora sobre o IV (Cm) resultando na escala dórica de C. A observação exclusiva da execução do V7 poderia induzir a dúvida entre a escala dórica e a menor melódica, uma vez que este não toca a sétima de $\mathrm{Cm}$. O V6 esvazia essa dúvida ao executar a $\mathrm{m} 7$ de $\mathrm{Cm}$ - a nota sib. Portanto, principalmente sobre um acorde menor relacionado à função subdominante (II nas tonalidades maiores e IV nas tonalidades menores),a ocorrência da escala dórica é observada. O mesmo tipo de evento pode ser observado no próximo exemplo:

Figura 114 - Baixaria utilizando a escala dórica - exemplo 2.

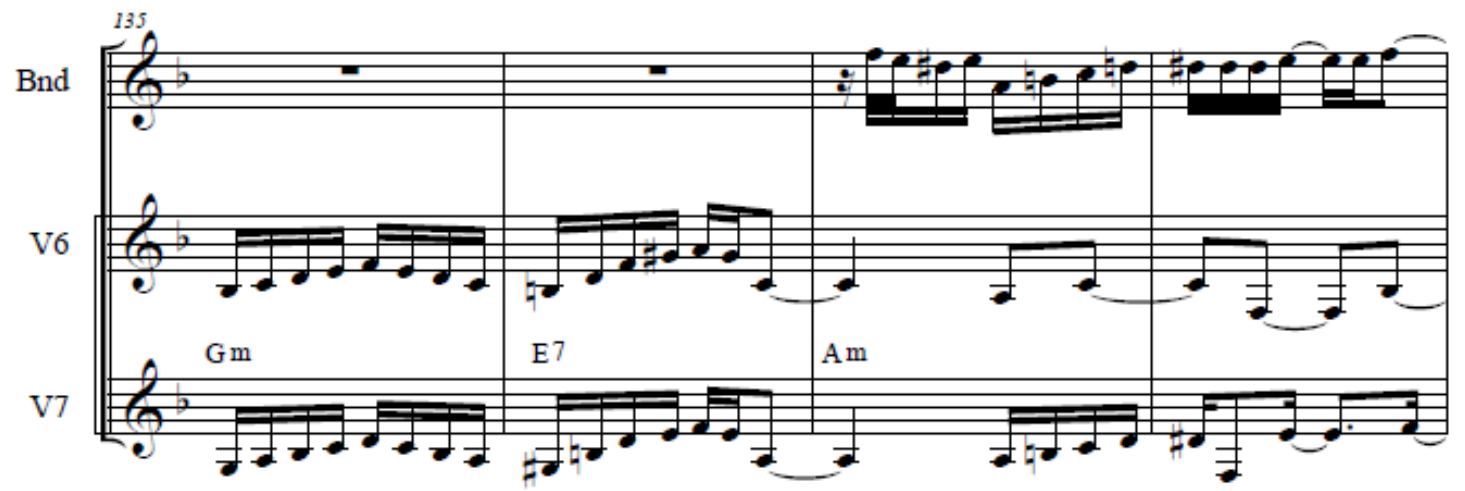

Fonte: Arabiando, transcrição do autor.

Na figura 110 o trecho está na tonalidade de F. Portanto, Gm é o II da tonalidade. A execução do V7 no compasso 135 não indica a escala menor utilizada, pois não passa nem 
pela sexta nem pela sétima da escala. O V6 realizado em terças executa a $6 \mathrm{~J}$ (a nota mi) e a m7 (a nota fá) da escala de Gm, conferindo-lhe a ambiência dórica. Portanto, novamente, a ocorrência da escala dórica sobre um acorde subdominante é observada. Contexto bastante semelhante é ilustrado na figura a seguir:

Figura 115 - Escala dórica na baixaria - exemplo 3.

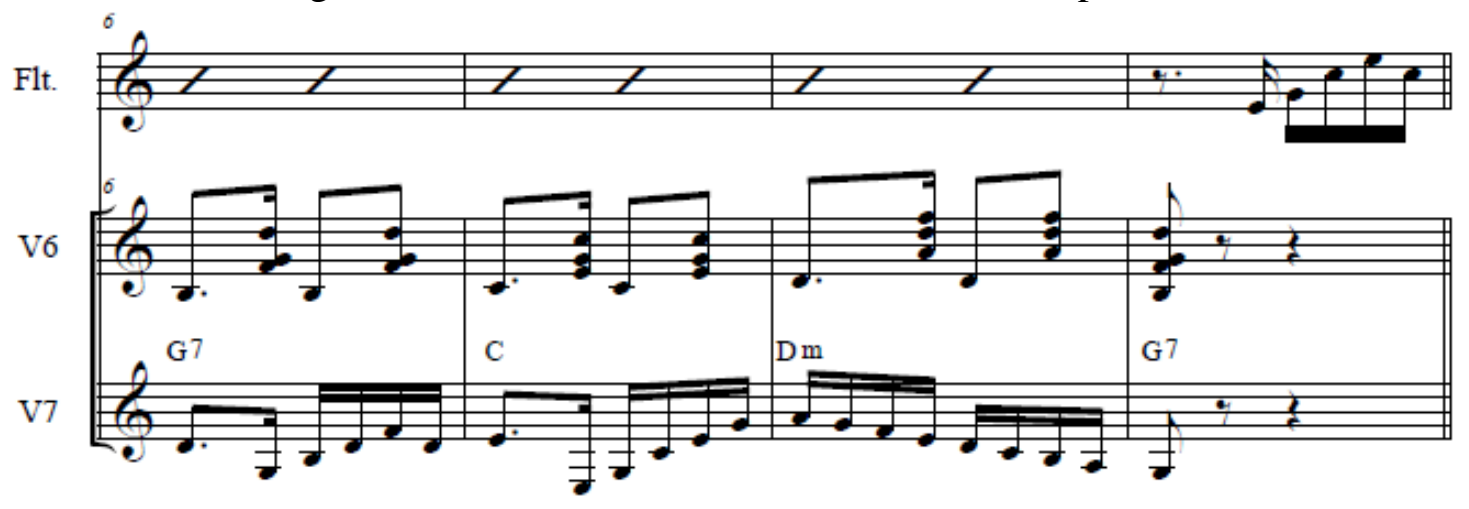

Fonte: Seu Lourenço no vinho, transcrição do autor.

Na figura acima observamos um trecho na tonalidade de C. O acorde Dm, no compasso 8, é, portanto, o II da tonalidade. Podemos observar que o V7 define a ambiência dórica sobre este acorde ao executar a m7 (dó) e a 6J (si).

Nos duetos acima apresentados, o V6 se comportou da maneira mais usual, ou seja, em um intervalo terça acima do V7. No início da secção foram apresentados exemplos de duetos em uníssono, como na parte A de Tenebroso. No entanto, em alguns casos, em menor número, os chorões tradicionais optam por outros intervalos, como os de oitava e os de sexta. No exemplo a seguir, uma Baixaria em intervalo de oitava no compasso 33 é utilizada:

Figura 116 - Duetos oitavados.

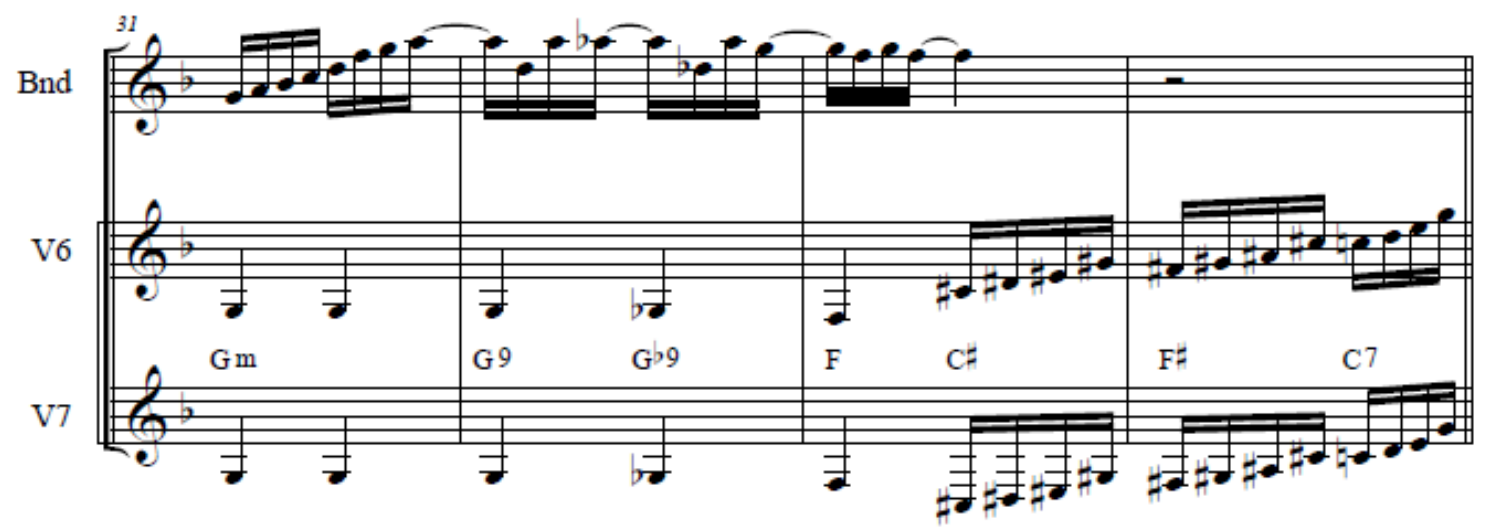

Fonte: Arabiando, transcrição do autor. 
Interessante observar que o baixo oitavado, neste caso, ocorre sobre um trecho harmônico normalmente chamado de Sexta Napolitana: I b6 b2 V. A partir do acorde C\#, toda a Baixaria ocorre em intervalo de oitava. No próximo exemplo, novamente, uma Baixaria oitavada é observada:

Figura 117 - Duetos oitavados - exemplo 2.
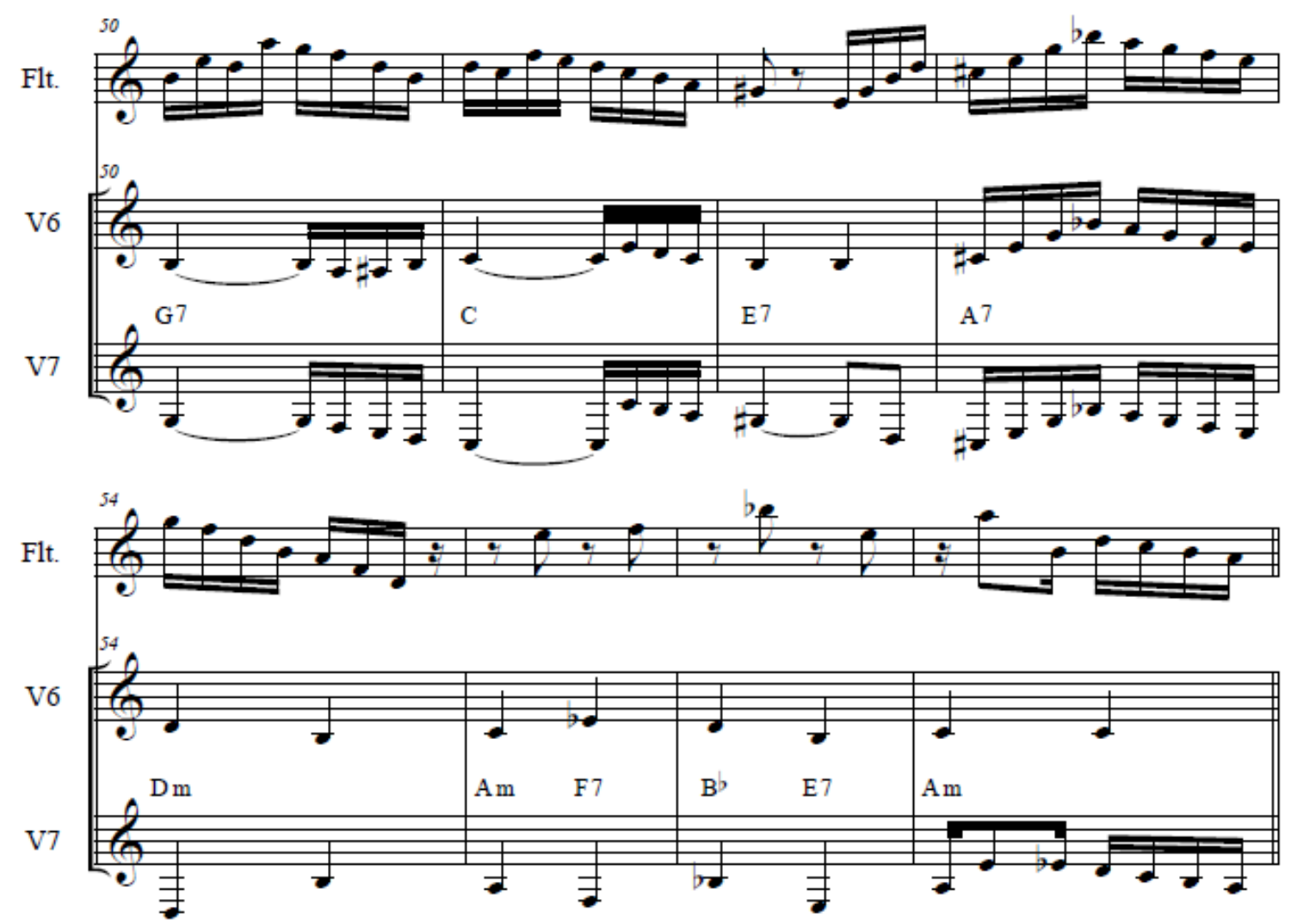

Fonte: Seu Lourenço no vinho, transcrição do autor.

No compasso 53, V7 e V6 realizam Baixaria em oitavas sobre o acorde de A7. Curioso notar que eles estão oitavados ${ }^{44}$ também com a melodia neste trecho. Os violões se diferenciam da melodia apenas no compasso 54. Convém observar que o intervalo de sexta, embora mais sofisticado e raro, também pode ocorrer em algumas situações. Em alguns casos, os violonistas podem ainda optar por um dueto com frases em caminhos opostos.

Figura 118 - Caminhos contrários na Baixaria.

\footnotetext{
${ }^{44}$ Neste caso específico não fica muito evidente a razão da escolha pelo baixo oitavado, uma vez que o dueto em terças seria perfeitamente possível.
} 


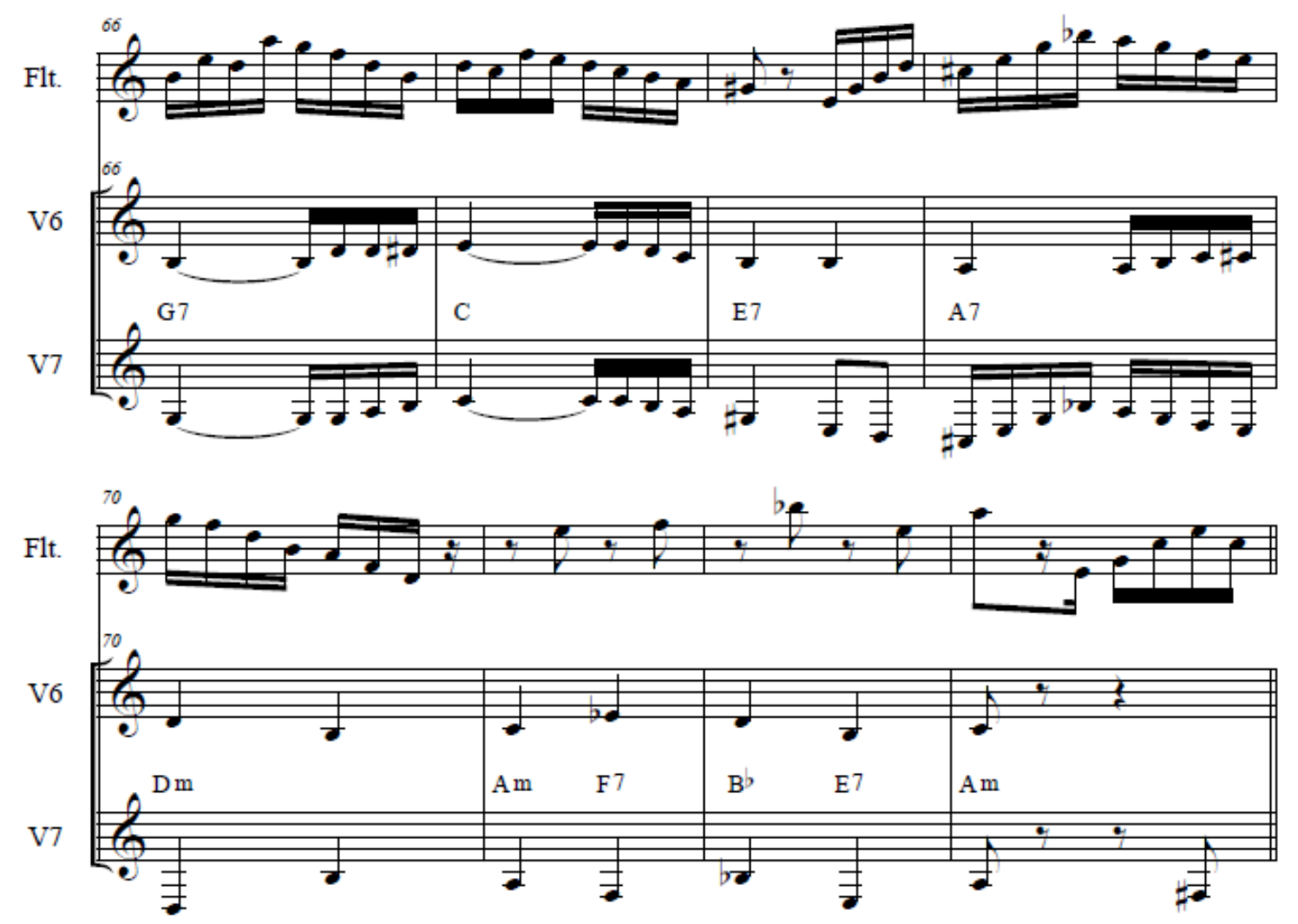

Fonte: Seu Lourenço no vinho, transcrição do autor.

No exemplo acima, uma Baixaria em caminhos contrários, no segundo tempo do compasso 69, é observada. Neste trecho, V7 e V6 partem em uníssono da nota lá e percorrem caminhos opostos, com V6 em caminho ascendente e V7 em caminho descendente. No compasso 70, eles chegam à nota ré oitavados.

\subsubsection{O Caráter Triádico e os Arpejos}

Ao contrário do Jazz e da Bossa Nova, o Samba e o Choro não possuem, em princípio, uma tendência "tetracórdica" para os acordes maiores e menores. Ou seja, os acordes maiores e menores, ao menos que se indique o contrário, são formados por tríades, sem tétrades subentendidas. Naturalmente, esse pensamento não se aplica às outras categorias de acordes, como dominantes, diminutos e aumentados.

Segundo Becker (1996, p.92): “Sétima maior ou nona, por exemplo, raramente são usadas em acordes com função tônica, a não ser no desfecho (...)”. Esta predileção pelas tríades na função tônica tem consequências nas Terças das baixarias, pois determinadas situações podem corromper o caráter triádico. 
O arpejo, recurso usado frequentemente em finalizações de Choros ou de partes de Choros, é um exemplo de fácil constatação de situação em que a “Terça” pode não ser exatamente um intervalo de "terça” de fato.

Tomemos uma típica finalização em Fá Maior realizada pelo V7, com o arpejo realizado na seguinte disposição- tônica, terça, quinta e oitava:

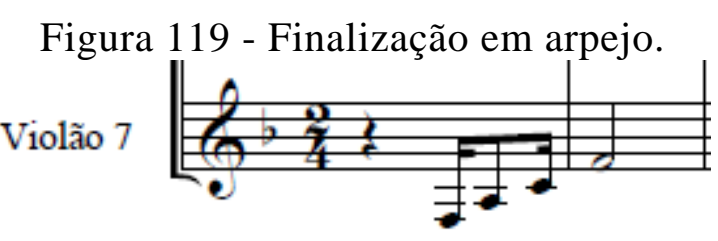

Fonte: Transcrição do autor.

Ao aplicarmos fielmente o conceito do intervalo de terça, a frase do V6 cordas será:

Figura 120 - Terças ”exatas” do arpejo original.

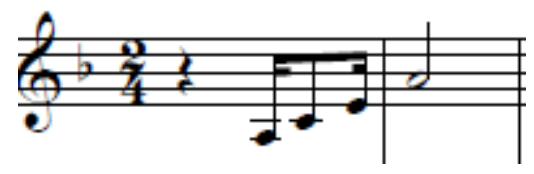

Fonte: Transcrição do autor.

No entanto, a nota mi (a terça da nota dó da frase original) parece "corromper” o caráter triádico do estilo, como se o resultado final das frases somadas soasse um acorde de F7M, fugindo das características originais. A Terça da quinta do arpejo original resultaria na sétima maior do acorde. Normalmente esse resultado não é visto com bons olhos pelos chorões tradicionais. Segundo Fernando César: “(...) tem de ser uma resposta em relação à tríade. Fá maior: fá, lá, dó. Mi já é sétima maior. A sétima descaracteriza a tríade”. (CÉSAR, 2015, E., p.27). Portanto, a resposta mais compatível com o estilo, de acordo com as gravações e os depoimentos nas entrevistas, seria: 
Figura 121 - “Terça” utilizada de fato no Choro.

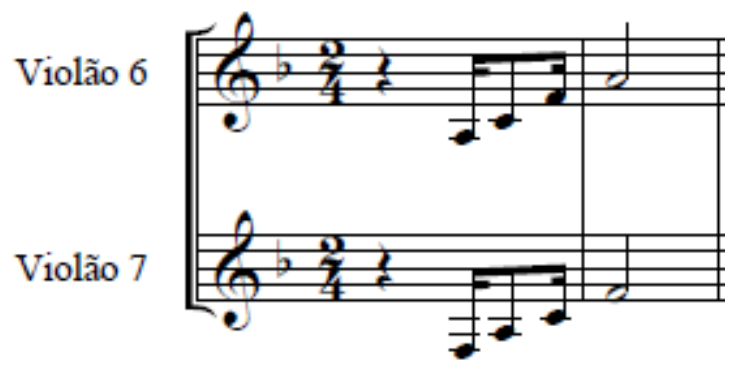

Fonte: transcrição do autor a partir dos depoimentos.

Neste caso, a terceira nota é um FÁ, portanto a quarta do DÓ do baixo original, aquele realizado normalmente pelo V7. No entanto, essa é a "terça” mais frequente nos exemplos estudados, mesmo não sendo uma frase construída exclusivamente com terças da frase original.

Ouso supor que tal solução poderia ocorrer em outras situações em que o baixo original passa pela quinta do acorde. No entanto, parece ocorrer predominantemente no caso do arpejo, provavelmente por esse se aproximar mais de um acorde do que a escala ou outras frases se aproximam. No caso das escalas, inclusive, a baixaria se dá perfeitamente em terças, como apresentado na figura 106.

Figura 122 - Finalização em arpejo - exemplo 2.

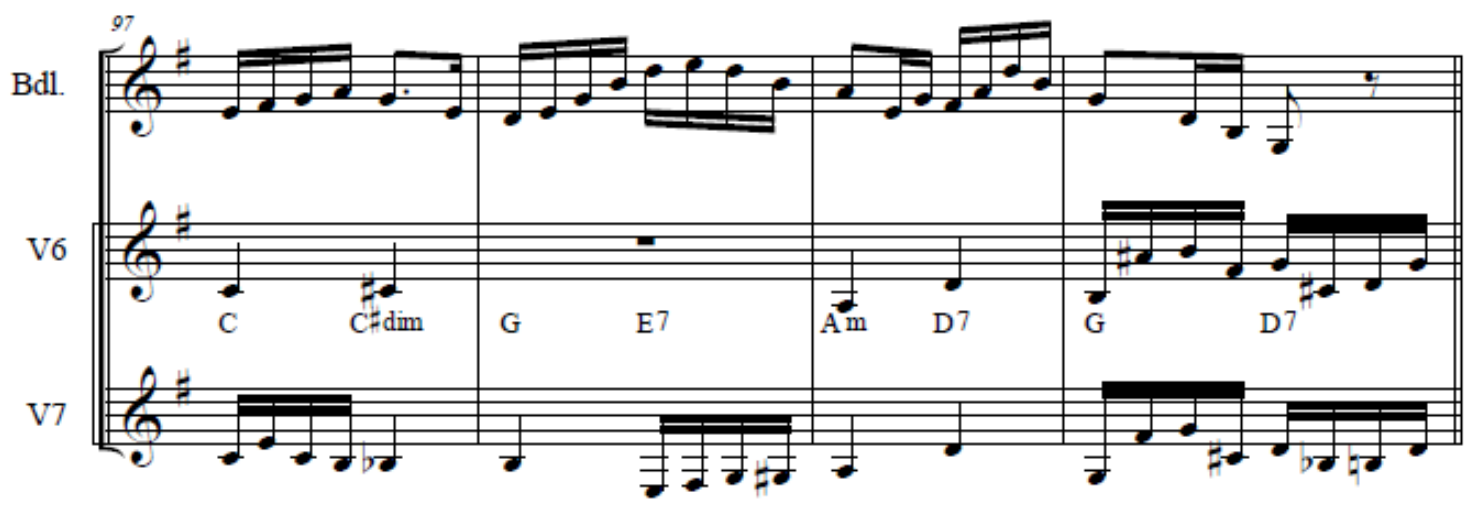

Fonte: Enigmático, transcrição do autor.

Na figura acima, no compasso 100, é observada uma forma sofisticada do arpejo. Em forma de apojatura nos tempos fracos, notas situadas meio tom abaixo das notas do arpejo são executadas antes das notas do arpejo. Se as frases forem simplificadas em função das notasalvo, o diálogo entre os violões se mostra como no exemplo a seguir: 
Figura 123 - Simplificação do compasso 100 da figura 122.

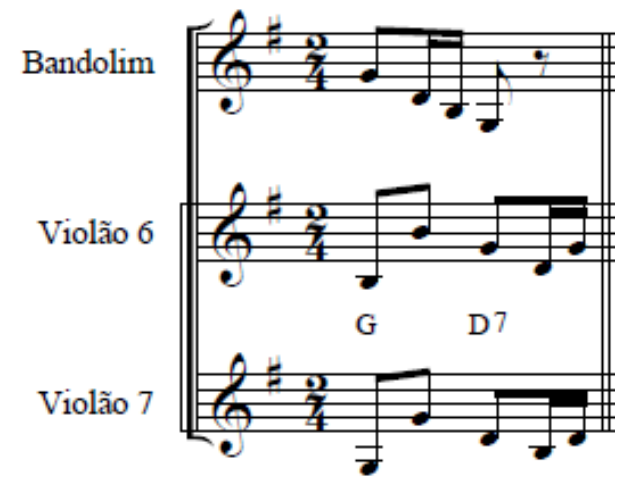

Fonte: Transcrição do autor.

Nesta simplificação a frase é tratada como uma construção sobre o arpejo de G para o V7 e as correspondentes terças para o V6. No entanto, quando o V7 realiza sua última nota no compasso (ré), o V6 não responde com a terça exata (fá\#) e sim com uma quarta (sol), respeitando a questão das tríades.

\subsubsection{O Caráter Triádico e os baixos repousados na sétima do Acorde Dominante}

Como foi adiantado na secção sobre as Inversões, há duas situações diferentes quando a baixaria repousa ${ }^{45}$ na sétima menor de um acorde.

Quando o acorde prepara um acorde menor, por exemplo, C7 - Fm, as terças do V6 se comportam normalmente, no intervalo exato de terça (terça menor, especificamente). Isto ocorre, imagino, por que o acorde diminuto é, assim como o próprio acorde dominante, uma das poucas tétrades recorrentes no contexto do Choro.

Figura 124 - Acorde diminuto como inversão de acorde dominante.

\footnotetext{
${ }^{45} \mathrm{O}$ termo repousar é aqui entendido genericamente como qualquer nota com valor de duração acima de uma semicolcheia.
} 


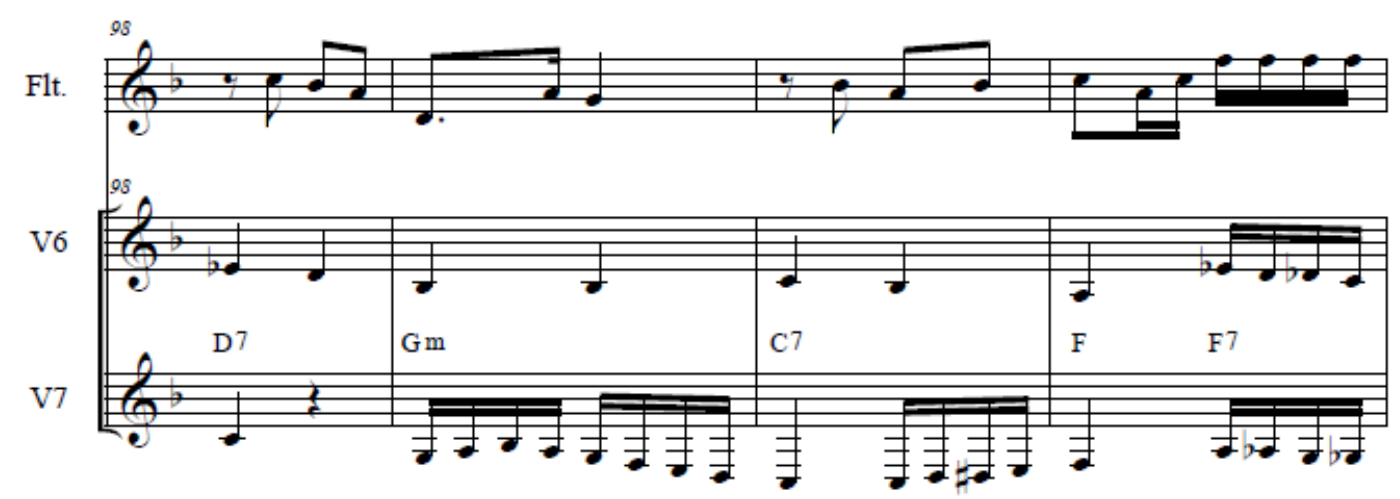

Fonte: Seu Lourenço no vinho, transcrição do autor.

Na figura 120, o acorde de D7/Eb (compasso 98), ou seja, Ebdim (“quarta” inversão) é utilizado como a Inversão do acorde D/C (terceira inversão).

Porém, na secção sobre Inversões, foi visto que, ao contrário do que foi discutido em tonalidades menores, no caso da preparação para acorde maior, as Terças não se comportam de maneira análoga. Assim como foi discutido na secção sobre Inversões, aqui também não existe um correspondente do acorde diminuto, capaz de realizar as terças exatas nesses casos de preparação para acorde maior. Ao procurar uma terça exata para o acorde $\mathrm{C} / \mathrm{Bb}$ é comum encontrar algo como C/D. Essa sonoridade não está em acordo com a sonoridade típica de Choro, pois o resultado sonoro é um acorde de D9sus4 ou D9sus4(b13), ou seja, acordes com quantidade de tensão divergente ao estilo. Nesses casos, os chorões procuram outras opções, como realizar Baixarias em oitavas ou sextas.

Em alguns casos, como resolução dessa questão, o V6 pode ainda optar em fazer a baixaria uma terça ABAIXO do V7, repousando, assim, na quinta do acorde (segunda inversão), em perfeita consonância com o estilo. Esta alternativa criativa é observada na gravação do Choro Sofres porque queres, realizada pelo grupo Época de Ouro. Para evitar o repouso sobre a $2 \mathrm{M}$ do acorde, ao final da baixaria, toda a frase é inteligentemente realizada uma terça abaixo da frase original:

Figura 125 - Baixaria terça abaixo. 


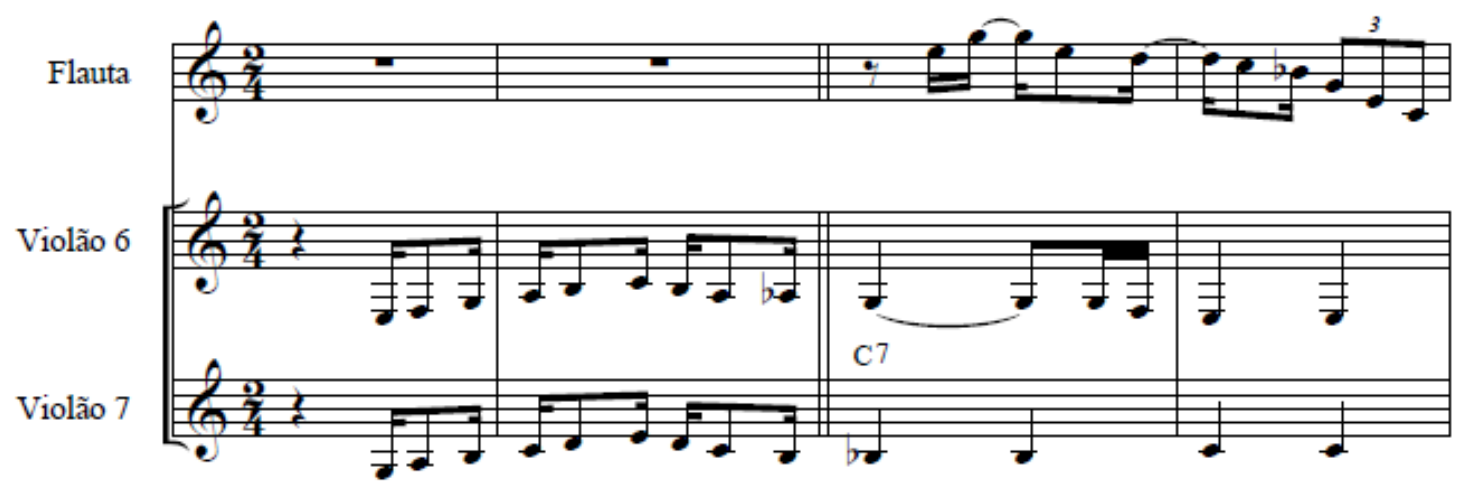

Fonte: Sofres porque queres (Pixinguinha), transcrição do autor.

Na figura acima, sobre os dois primeiros compassos, a realização do dueto uma terça abaixo da voz principal é observada. Na transcrição, é difícil precisar com absoluta certeza que é o V6 que executa a frase mais grave por causa da qualidade da gravação. No entanto, por meio de outras gravações é sabido que a voz principal é:

Figura 126 - Baixo de obrigação de Sofres porque queres

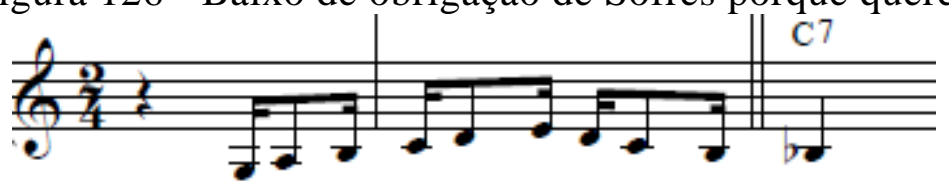

Fonte: transcrição do autor.

O próprio Pixinguinha realiza esse baixo no sax tenor em gravação com o flautista Benedito Lacerda. Esta frase é, portanto, um baixo de obrigação e, normalmente, é realizada pelo V7 em outras gravações que não apresentam dueto de violões neste trecho. Suponho então que ela aqui é realizada novamente pelo V7, ficando a cargo do V6 a realização da frase mais grave, uma terça abaixo. No entanto, como em muitas outras gravações, muitas vezes se torna difícil afirmar a exata divisão entre V6 e V7 nas Baixarias. Ao admitir ser o V6 quem realiza a frase mais grave, é possível notar, nos dois primeiros compassos, que toda a frase está uma terça abaixo da frase do V7. No terceiro compasso, o V7 repousa com o baixo na sétima ( $\mathrm{C} / \mathrm{Bb}$ - terceira inversão) e o V6, uma terça abaixo, repousa como baixo na quinta (C7/G - segunda inversão). Portanto, é certo que “alguém” (V6 ou V7) realiza a frase uma terça abaixo da frase de obrigação para evitar ter de terminar com o baixo uma terça acima da m7 da Baixaria original.

\subsubsection{Baixarias como melodias}


Em algumas gravações de Choro, embora não muito frequentes, o trabalho das baixarias dos violões também pode ser percebido fora do contexto do contraponto. Os violões podem realizar introduções/finalizações ou até mesmo melodias de determinados trechos ou de partes inteiras do Choro.

As Baixarias como melodia podem ser observadas no tango Tenebroso, já citado nas figuras 95 e 101.

\subsubsection{Gemedeira}

Outra técnica associada às Baixarias é a gemedeira, que se trata de um grande "ligado" na região médio-grave do instrumento. Jorge Cardoso aponta que: “A gemedeira era o discurso musical produzido em melodia romântica, geralmente em um registro mais agudo do violão de 6 cordas”. (CARDOSO, 2016, E., p. 29). Segundo Becker (2013, p.22): “outro recurso característico, principalmente no acompanhamento do V6 no Choro, é o que ficou conhecido como gemedeira, uma glissando, em geral na quarta corda”.

Figura 128 - Gemedeira.

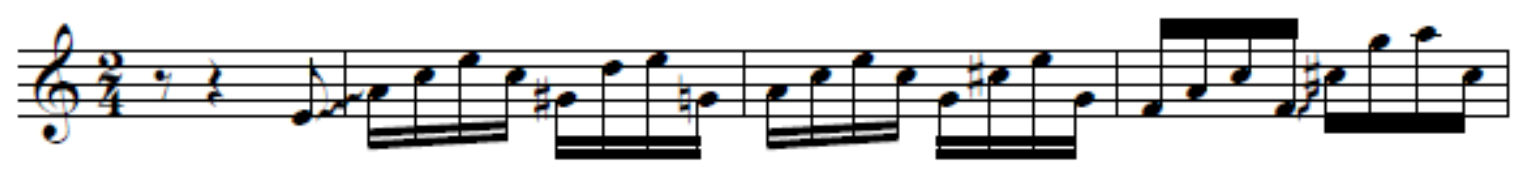

Fonte: BECKER, 2013, p.22.

Na figura acima é possível observar o “deslize” da nota mi para a nota lá, na transição do compasso 1 para o compasso 2 e depois da nota fá para a nota dó\#, do primeiro para o segundo tempo do compasso 4.

Cidinho 7 Cordas (2015, E., p.25), de certa forma, amplia essa visão. Ao invés de relacionar a uma técnica, o faz em relação a uma forma de tocar violão: “O violão gemedeira, além de harmonizar em acordes, se destaca em fraseados na harmonia sem atropelar a melodia”. Ainda segundo Becker (2013), Carlinhos Leite foi um dos grandes mestres da gemedeira. Segundo o violonista André Bellieny (2015, E., p.5), as gemedeiras estão entre as principais habilidades de um bom violonista: "Preencher a harmonia nas frequências médias, segundas vozes, frases médio-agudas e gemedeiras”. 
Portanto, diante de tantas nuances, a capacidade de realizar Baixarias no V6 evidencia um alto nível de concentração e percepção musical do instrumentista, sobretudo quando conjugada às Baixarias do V7. Aponta ainda para uma desenvolvida velocidade de reflexo e uma destacada aptidão para a música coletiva, dado o caráter complementar dessa performance. 


\section{CONCLUSÃO - Ninguém aprende Choro no colégio.}

O aprendizado livre, característico da tradição do Choro, certamente não cabe nas quatro paredes de uma sala de aula. (LARA FILHO, 2009, p.99)

O texto acima aponta para a importância da Roda de Choro na assimilação da linguagem do gênero. Com grandes semelhanças Noel Rosa havia escrito que "Batuque é um privilégio, ninguém aprende Samba no colégio”, na letra de Feitio de Oração, levemente alterada no título deste capítulo. Portanto, o convívio prático e coletivo com o estilo é essencial para a formação de um chorão.

Neste trabalho procurei identificar e analisar parte da performance relacionado ao acompanhamento do V6 no Choro, como forma de registrar essa expertise, ressalvadas as limitações do processo e da notação musical.

No processo de responder aos objetivos da pesquisa entrevistei violonistas de 6 cordas de renome na cena do Choro e transcrevi e analisei repertório de gravações. Partir das entrevistas foi importante para me aproximar do mundo "prático” do Choro.

Os resultados da pesquisa apontam para quatro habilidades fundamentais para o violonista de 6 cordas: as Harmonias, as Levadas, as Inversões e as Baixarias. Estas exigem uma aprendizagem vinculada a situações reais de performance. Cabe lembrar que a performance do Choro pode acontecer em dois contextos bem diferentes: 1) em uma apresentação ensaiada (ou gravação); ou 2) em uma Roda de Choro. Esta distinção, naturalmente, tem consequências importantes em relação à execução do V6.

Numa apresentação “planejada” (ou gravação), os violonistas, provavelmente, terão a oportunidade de ensaiar as Harmonias, as Levadas, as Inversões e as Baixarias a serem realizadas, ou, pelo menos, grande parte delas, observando os idiomatismos descritos anteriormente. Ou seja, é um ambiente um pouco mais controlado nesse sentido. A tarefa dos violonistas será árdua, mas não tanto como numa Roda de Choro.

A Roda de Choro é um contexto bem mais exigente para os violonistas, pois eles precisarão lançar mão dos recursos relacionados às Habilidades Musicais descritas de forma instantânea. Em relação às Baixarias, por exemplo, com exceção dos baixos de obrigação que alguns Choros exigem (já tacitamente combinados, por serem sempre os mesmos, decorrentes da própria composição ou de arranjos consagrados), todas outras baixarias serão acordadas ali naquele momento, normalmente durante a execução. 
Portanto, o violonista de 6 cordas precisa estar realmente muito atento à performance do violonista de 7 cordas, pois este último é quem detém a “frase original” a ser realizada. A Baixaria do V6 deve decorrer da Baixaria do V7 (consequentemente, também a Inversão do V6 decorrerá da Inversão do V7). Apresenta-se, de fato, como uma difícil tarefa para o violonista de 6 cordas descobrir (em alguns casos o verbo correto seria “prever”) qual será a frase do V7 e, ainda por cima, descobrir como responder a ela.

Na performance, o V6 é desafiado continuamente e os conhecimentos e as habilidades exigidas por esse instrumentista está se perdendo. Por isso, imagino que este trabalho se apresente não apenas como uma memória da prática desse instrumento, mas uma forma de sistematizar e refletir sobre a prática do V6 no Choro.

Com relação às habilidades do V6, a Harmonia, as Levadas, as Inversões e as Baixarias estão intimamente relacionadas e integradas, mas apresentam particularidades que exigem atenção, intuição e interação com os outros instrumentos, evocando um importante senso de música coletiva. Da Harmonia, destaco a perspicácia harmônica, os encadeamentos, as modulações e os clichês harmônicos. A Levada simboliza a "articulação cultural” brasileira, influenciada por danças europeias e africanas, sobretudo, e o papel do V6 na seção rítmica de um Regional, ao lado do Cavaco e do Pandeiro. As Inversões e as Baixarias representam a performance complementar com o V7, a capacidade de estar atento ao outro violonista para evitar redundâncias e completar suas ideias musicais.

Na Roda de Choro essas habilidades são vivenciadas, dialogadas, desenvolvidas e aprendidas. A imitação é uma das suas escolas. Por exemplo, no instante da Roda, alguns violonistas de 7 cordas, mais experientes, têm por hábito repetir as mesmas frases quando a música retorna àquele mesmo ponto, ou seja, repetir os baixos na reexposição de qualquer das partes da música. Este artifício possibilita que o violonista de 6 cordas possa responder com as Terças às Baixarias que ouviu na primeira exposição do trecho. Esse procedimento gera um diálogo violinístico previsível e ao mesmo tempo imprevisível e inovador. Augusto Contreiras, em seu depoimento para esta pesquisa, destaca que Damázio indicava que o V7 repetisse as frases nas reexposições, em favor do diálogo violonístico. Naturalmente, trata-se de uma prática musical bastante avançada, tanto para o V7 quanto para o V6.

Nesse complexo enlace, fica evidente o alto nível de qualidade dos músicos que se propõem a esse tipo de performance. Mais do que isso, fica evidenciado, nesta trama, o sutil diálogo que os músicos têm de estar dispostos a realizar. O V7, da sua parte, precisa repetir baixos e ideias com consistência, para que o V6 possa compreendê-lo. O V6, por sua vez, 
precisa focar sua energia em, ao mesmo tempo em que realiza a harmonia da música, compreender o fraseado do V7, para complementá-lo na próxima exposição.

Esse tipo de “Empatia Musical” está se perdendo, pois grande parte dos chorões de hoje em dia não tem interesse ou disponibilidade para desenvolver. Suspeito que pode ser este um dos motivos da diminuição das duplas de violões nas Rodas de Choro.

Por outro lado, o diálogo V7 e V6 evidencia a importância da Roda de Choro na assimilação dos idiomatismos que envolvem a performance de Choro. A complexidade da performance coletiva implica na condição de que qualquer proposta de assimilação interpretativa relacionada ao Choro, distinta de uma Roda de Choro, deve estar ciente de suas sérias limitações. A grande escola do Choro é a Roda de Choro, que até o momento se apresenta como a mais eficaz ferramenta de formação, por vezes tida como “informal”.

Nesse sentido, não posso deixar de mencionar o trabalho de Assis (2009), que ao estudar a transmissão do conhecimento musical vocal tido como "informal” em comunidades rurais, aponta 3 principais estratégias de disseminação do conhecimento: Imitação, Demonstrações Práticas e Explicações Orais. Estas categorias estão relacionadas entre si, mas diferenciam-se quanto à intencionalidade. A Imitação envolve a observação do outro, sem intencionalidade de se ensinar, mas apenas de se aprender “copiando”. As Demonstrações Práticas envolvem intencionalidade e demonstração, quando quem quer aprender pergunta e o outro demonstra e ensina. A última categoria de Assis (2009), as Explicações Orais, estão relacionadas com o ensinar: há uma intencionalidade de ensinar, mas não, necessariamente, de aprendizagem: aprende-se quando, quanto e o quê se quer.

Imagino que tais categorias possam ser utilizadas na compreensão de alguns aspectos do ensino e aprendizagem do Choro e, penso que grande parte das Habilidades Musicais trabalhadas nesta pesquisa se associam majoritariamente às Explicações Orais. A Roda de Choro normalmente se ocupa das questões relacionadas às Explicações Orais e, sobretudo, à Imitação.

Portanto, apesar da importância das categorias de demonstração e explicação, acredito que, em geral, a Imitação, com suas nuances, é parte fundamental do processo histórico de apropriação do conhecimento. Em particular, no Choro, ela é um expediente utilizado com frequência pelos chorões, sendo a Roda de Choro e as gravações as principais fontes de recursos a serem apreendidos. 
Tal riqueza idiomática aponta para a necessidade de registro e iniciativas de preservação dessa tradicional performance musical brasileira, dada a pequena quantidade de registros disponíveis a despeito das limitações da notação musical. Assim, todos os esforços descritivos - embora um tanto reflexivos, é verdade - da presente pesquisa pretendem, apenas e simplesmente, registrar e promover um pouco do conhecimento disseminado nas Rodas e nas gravações e, se possível, ajudar a complementar na aprendizagem da linguagem do estilo, a despeito das limitações citadas. Além disso, o presente trabalho naturalmente não esgota o mapeamento das habilidades musicais do V6 e espero que sirva de auxílio para trabalhos seguintes. Mesmo com as limitações citadas, imagino a importância de pesquisas desse tipo na valorização da música popular e sua performance.

Viva o Choro! Viva a Roda de Choro! 


\section{REFERÊNCIAS BIBLIOGRÁFICAS}

ALBERTI, Verena. Ouvir contar: textos em história oral. Rio de Janeiro: Editora FGV, 2007.

ALBUQUERQUE, Wlamyra; FILHO, Walter. Uma história do negro no Brasil. Salvador: Centro de Estudos Afro-Orientais; Brasília: Fundação Cultural Palmares, 2006.

ARAGÃo, Pedro de Moura; PAES, Ana. Apostila de Choro. Primeiro Festival de Choro, 2006.

ARAGÃO, Pedro de Moura. O carteiro e a cultura popular na belle époque: Alexandre Gonçalves Pinto e o Choro. In: SIMPÓSIO BRASILEIRO DE PÓS-GRADUANDOS EM MÚSICA. Anais do II SIMPOM. Rio de janeiro: 2012.

ARAGÃO, Pedro de Moura. Signos sociais e musicais na música popular: um estudo de caso da Belle Èpoque. Música e Cultura. Vol.7, n. 1, p. 88-103. Rio de Janeiro: 2012.

ARAGÃO, Pedro de Moura. Entre polcas, quadrilhas e sambas: processos de mudança musical no choro a partir de análises comparativas entre gravações fonográficas no século XX. Claves. Vol. 10, p. 61-80. Março de 2014.

BARBOZA, Marília. Pelos caminhos do Choro - Festival de Choro do Estado do Rio de Janeiro. Rio de Janeiro: Mis Editorial, 2001.

BECKER, José Paulo. O acompanhamento do violão de 6 cordas no Choro a partir de sua visão no conjunto Época de Ouro. Dissertação (Mestrado em Música). UFRJ. Rio de Janeiro: 1996.

BECKER, José Paulo. Levadas brasileiras para violão. Rio de Janeiro: 2013.

BITTAR, Iuri Lana. Jaime Florence (Meira) e sua atividade artística nos grupos Voz do sertão, Regional de Benedito Lacerda e Regional do Canhoto. Dissertação (Mestrado em Música). UFRJ. Rio de Janeiro: 2011.

BOLÃO, Oscar. Batuque é um privilégio. Rio de Janeiro: Editora Lumiar, 2010.

BRAGA, Luiz Otávio. O Violão de 7 cordas: teoria e prática. Rio de Janeiro: Editora Lumiar, 2002.

CAETANO, Rogério. Sete Cordas, técnica e estilo. Rio de Janeiro: Garbolights produções artísticas, 2010.

CASTAGNA, Paulo. História e música no Brasil - Música na América portuguesa. São Paulo: Alameda, 2010.

CARPEAUX. O livro de ouro da história da música: da idade média ao século XX. Rio de Janeiro: Ediouro, 2001. 
CAZES, Henrique. Choro: do quintal ao Municipal. São Paulo: Ed. 34, Coleção Ouvido Musical, 1998.

CHEDIAK, Almir. Harmonia e Improvisação. 7. ed. Rio de Janeiro: Lumiar Editora, 1986.

CHEDIAK, Almir. Songbook de Choro. Rio de Janeiro: Lumiar Editora, 2006.

D’ÁVILA, Nícias Ribas. O Batuque: das raízes afro-indígenas à Música Popular Brasileira. In: COLÓQUIO INTERNACIONAL DE ESTUDOS SOBRE A AMÉRICA LATINA DE COMUNICAÇÃO, Celacom. Anais, p. 1-24, 2009.

DICIONARIO CRAVO ALBIN DA MÚSICA POPULAR BRASILEIRA. Sátiro Bilhar. Rio de Janeiro, Instituto Cultural Cravo Albin. Disponível em: <http://dicionariompb.com.br/satiro-bilhar> Acesso em: setembro de 2015.

DICIONARIO CRAVO ALBIN DA MÚSICA POPULAR BRASILEIRA. César Faria. Rio de Janeiro, Instituto Cultural Cravo Albin, 2007. Disponível em:

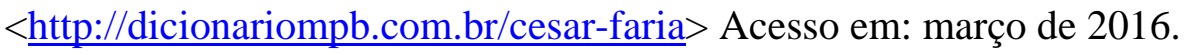

DINIZ, André. Joaquim Callado, O Pai do Choro. Rio de Janeiro: Editora: Jorge Zahar, 2008.

FARIA, Nelson; KORMAN, Cliff. Inside the brazilian rhythm section, 2.ed. Petaluma: Sher Music CO, 2001.

GARCIA. Lenise Aparecida Martins. Competências e Habilidades: você sabe lidar com isso? Educação Pública, CECIERJ. Disponível $<$ http://www.educacaopublica.rj.gov.br/biblioteca/educacao/0023d.html $>$. Acesso em: setembro de 2015.

GOMES, Flávio dos Santos. Mocambos e quilombos: uma história do campesinato negro no Brasil. São Paulo: Claro Enigma, 2015.

GROUT, Donald; PALISCA, Claude. História da música ocidental. Lisboa: Gradiva Publicações, 2007.

GUEST, Ian. Arranjo: método prático. Rio de Janeiro: Irmãos Vitale, 1996.

KIEFER, Bruno. História da música brasileira. Porto Alegre: Editora Movimento, 1976.

LARA FILHO, Ivaldo Gadelha. O Choro dos chorões de Brasília. Dissertação (Mestrado em Música). UnB. Brasília: 2009.

LEME, José Alexandre Carvalho. Os Alicerces da Folia: A Linha de Baixo na Passagem do maxixe para o Samba. 170f. Dissertação (Mestrado em Música). Unicamp. Campinas: 2006.

LIVINGSTON-ISENHOUR, Tamara Elena; GARCIA, Thomas George Caracas. Choro: A social history of a brazilian popular music. Indiana University Press: 2005. 
LOPES, Nei. Partido Alto, Samba de Bamba. Rio de Janeiro: Pallas, 2005.

MACHADO, Cacá. História e música no Brasil - Batuque: mediadores culturais no final do século XIX. São Paulo: Alameda, 2010.

MARCÍLIO, Clara Crevelanti. Chiquinha Gonzaga e o Maxixe. Dissertação. (Mestrado em Música). Universidade Estadual Paulista. São Paulo, 2009.

MARINHO-ARAÚJO, Claisy Maria; RABELO, Mauro Luiz. Avaliação educacional: $a$ abordagem por competências. Campinas, 2015.

MONTANDON, Maria Isabel. Perguntas que respondem: preparando o entrevistador para a pesquisa qualitativa. In: XVIII CONGRESSO DA ASSOCIAÇÃO NACIONAL DE PESQUISA E PÓS-GRADUAÇÃO (ANPPOM). Salvador: 2008.

MONTEIRO, Maurício. História e música no Brasil - Aspectos da música no Brasil na primeira metade do século XIX. São Paulo: Alameda, 2010.

PARANHOS, Adalberto. Os desafinados: Sambas e bambas no Estado Novo. São Paulo: Editora Intermeios, 2015.

PAZ, Ermelinda. A história e a glória de Jacob. Rio de Janeiro: Funarte, 1997.

PELLEGRINI, Remo. Análise dos acompanhamentos de Dino Sete Cordas em Samba e Choro. Dissertação (Mestrado em Música). Unicamp. Campinas: 2005.

PEREIRA, Marco. Ritmos brasileiros. Rio de Janeiro: Garbolights produções artísticas, 2007.

PERRENOUD, Philippe. Dez novas competências para ensinar. Porto Alegre: Artmed, 2000.

PESSOA, Felipe Ferreira. Cuidado violão: as transformações no acompanhamento dos violões nos conjuntos de Choro. Dissertação (Mestrado em Música). UnB. Brasília: 2012.

PRATA, Sérgio. Os Regionais e o Choro. Centro Cultural Augusto Carvalho (CECAC),

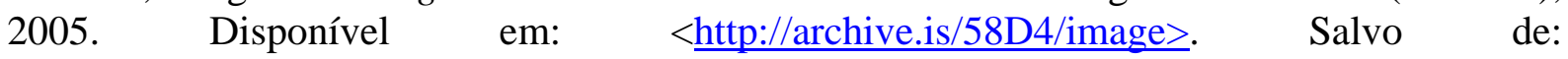
$<$ http://www.cecac.org.br/mat\%E9rias/Os_regionais_e_o_choro_Sergio_Prata.htm $>$. Acesso em: setembro de 2015.

PINTO, Alexandre Gonçalves. O Choro: reminiscências dos chorões antigos. Rio de Janeiro: Funarte, 2009.

RIBEIRO, Darcy. O povo brasileiro: a formação e o sentido do Brasil. São Paulo: Companhia da Letras, 1995.

SANDRONI, Carlos. Feitiço decente: transformações do samba no Rio de Janeiro (19171933). Rio de Janeiro: Jorge Zahar / Editora UFRJ, 2001. 
SANTOS, Regina Antunes. Mobilização de conhecimentos musicais na preparação do repertório pianístico ao longo da formação acadêmica: três estudos de caso. Tese (Doutorado em Música). UFRGS. Rio Grande do Sul, 2007.

SCHAFER, Murray. A afinação do mundo. São Paulo: Fundação Editora da Unesp, 1997.

SÈVE, Mário \& GANC, David. Choro: Duetos - Pixinguinha e Benedito Lacerda. São Paulo: Irmãos Vitale, 1999a.

SÈVE, Mário. Vocabulário do Choro. Rio de Janeiro: Lumiar Editora, 1999b.

SÈVE, Mário. O fraseado no Choro. In: SIMPÓSIO BRASILEIRO DE PÓSGRADUANDOS EM MÚSICA. Anais do III SIMPOM. Rio de janeiro: 2014.

SÈVE, Mário. Notações, regras e interpretação. In: SIMPÓSIO BRASILEIRO DE PÓSGRADUANDOS EM MÚSICA. Anais do IV SIMPOM. Rio de Janeiro: 2016.

SILVA, Abel Raimundo. Oficinas de Performance Musical: uma metodologia interdisciplinar para uma abordagem complexa de performance musical. In: SIMPÓSIO DE COGNIÇÃO E ARTES MUSICAIS. Anais do IV SIMCAM. 2008.

SLOBODA, John. A mente musical. Londrina: Eduel, 2010.

SOARES, Alencar. Teoria das Árvores Harmônicas. No prelo.

SOUZA, Jessé. A tolice da inteligência brasileira (ou como o país se deixa manipular pela elite). Leya Editora, 2015.

SWANWICK, Keith. Musical Knowledge: intuition, analysis and music education. Londres: 1994.

TABORDA, Márcia. Violão e identidade nacional. Rio de Janeiro: Civilização brasileira, 2011.

TINHORÃO, José Ramos. História social da música popular brasileira. 2.ed. São Paulo: Editora 34, 1998.

TRAVASSOS, Elizabeth. Modernismo e música brasileira. Rio de Janeiro: Editora Jorge Zahar, 2000.

\section{Áudios}

CHORANDO NA PRAIA - disco: Inéditas de Jacob do Bandolim (Déo Rian e conjunto Noites Cariocas).

VIBRAÇÕES - disco: Vibrações (Jacob do Bandolim e Conjunto Época de Ouro).

CUIDADO VIOLÃO - disco: Choros Imortais (Altamiro Carrilho e regional do Canhoto). 
SEU LOURENÇO NO VINHO - disco: Chorando Callado 2 (Chorando Callado)

NAQUELE TEMPO - disco: Choros Imortais (Altamiro Carrilho e Regional do Canhoto)

ENIGMÁTICO - disco: Choro Livre (Reco do Bandolim e grupo Choro Livre)

ARABIANDO - disco: Prêmio Renato Russo (Choro Livre e Liga Tripa)

\section{Depoimentos}

CASA DO CHORO. João da Bahiana. Enciclopédia Ilustrada do Choro no séc. XIX. Rio de Janeiro: Instituto Casa do Choro, 2013. Disponível em: < http://www.casadochoro.com.br/acervo/cards/view/1680>. Acesso em: março de 2016.

DINO 7 CORDAS. Entrevista concedida ao maestro Nelson Macedo. 1992. Disponível em: $<$ https://www.youtube.com/watch?v=cmwtxht885g $>$. Acesso em: abril de 2016.

ÉPOCA DE OURO, Conjunto. Programa Ensaio, 1973. Disponível em: <https://www.youtube.com/watch?v=X5FrC3YQOII>. Acesso em: novembro de 2015.

\section{Partituras}

GONZAGA, Chiquinha. Gaúcho (Corta-jaca). Acervo Chiquinha Gonzaga, 2011. Disponível em: <http://www.chiquinhagonzaga.com/acervo/partituras/gaucho_ca-e-la_piano_cifra.pdf $>$. Acesso em março de 2016.

NAZARETH, Ernesto. Apanhei-te cavaquinho. Casa Mozart, 1914. In: Ernesto Nazareth 150 anos, Instituto Moreira Salles. Partitura, $1^{\text {a }}$ edição. Disponível em: <http://www.ernestonazareth150anos.com.br/files/uploads/work_elements/work_20/apa nhei_te_cavaquinho.pdf $>$. Acesso em março de 2016.

2012. Partitura Editada. Versão original de 1914. Disponível em: <http://www.ernestonazareth150anos.com.br/files/uploads/work_elements/work_20/apa nhei_te_cavaquinho_piano.pdf $>$. Acesso em março de 2016.

Atlântico. Musica Brasilis e Instituto Moreira Salles, 2012. Partitura

Editada. Versão original de 1921. Disponível em: <http://www.ernestonazareth150anos.com.br/files/uploads/work_elements/work_23/atlantico _piano.pdf $>$. Acesso em abril de 2016.

. Brejeiro. Fontes \& Cia, 1893. In: Ernesto Nazareth 150 anos, Instituto Moreira Salles. Partitura, $1^{\text {a }}$ edição. Disponível em: $<$ http://www.ernestonazareth150anos.com.br/files/uploads/work_elements/work_31/brejeiro.p df $>$. Acesso em janeiro de 2016. 
. Dengoso. Musica Brasilis e Instituto Moreira Salles, 2012. Partitura

Editada. Versão original de 1907. Disponível em: $<$ http://www.ernestonazareth150anos.com.br/files/uploads/work_elements/work_52/dengoso_ piano.pdf $>$. Acesso em março de 2016.

Editada Versão . Dirce. Musica Brasilis e Instituto Moreira Salles, 2012. Partitura $<$ http://www.ernestonazareth150anos.com.br/files/uploads/work_elements/work_55/dirce_pia no.pdf>. Acesso em janeiro de 2016

. Escorregando. 1923. In: Ernesto Nazareth 150 anos, Instituto Moreira Salles. Partitura, $1^{\text {a }}$ edição. Disponível em: $<$ http://www.ernestonazareth150anos.com.br/files/uploads/work_elements/work_63/escorrega ndo.pdf $>$. Acesso em março de 2016.

. Janota. São Paulo, Casa Bevilacqua, 1926. In: Ernesto Nazareth 150 anos, Instituto Moreira Salles. Partitura, $1^{\text {a }}$ edição. Disponível em: $<\underline{\text { http://www.ernestonazareth150anos.com.br/files/uploads/work_elements/work_103/janota.p }}$

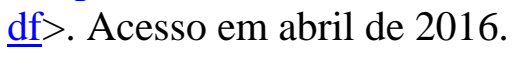

Disponível

Odeon. Instituto Moreira Salles, 2012. Partitura adaptada para cifra.

$<$ http://www.ernestonazareth150anos.com.br/files/uploads/work_elements/work_136/odeon cifra.pdf $>$. Acesso em janeiro de 2016.

. Odeon. Musica Brasilis e Instituto Moreira Salles, 2012. Partitura editada. Versão original de 1909. Disponível em: $<$ http://www.ernestonazareth150anos.com.br/files/uploads/work_elements/work_136/odeon piano.pdf $>$. Acesso em janeiro de 2016.

. Tenebroso. Musica Brasilis e Instituto Moreira Salles, 2012.

Partitura editada. Versão Original de 1913. Disponível em: $<$ http://www.ernestonazareth150anos.com.br/files/uploads/work_elements/work_180/tenebro so_piano.pdf $>$. Acesso em abril de 2016.

. Turuna. Musica Brasilis. De: Pixinguinha na pauta - 36 arranjos para o programa O Pessoal da Velha Guarda. Instituto Moreira Salle/Imprensa Oficial, 2010. 1 partitura. Disponível em: $<$ http://musicabrasilis.org.br/sites/default/files/turuna_banda_en.pdf $>$. Acesso em abril de 2016.

. Vésper. Musica Brasilis e Instituto Moreira Salles, 2012. Partitura \begin{tabular}{lllll}
\hline editada. & Versão & Original de & Disponível
\end{tabular} em: <http://www.ernestonazareth150anos.com.br/files/uploads/work_elements/work_190/ves per_piano.pdf $>$. Acesso em janeiro de 2016.

VILLA-LOBOS, Heitor. Valsa-Choro: "Suíte Popular Brasileira” n³. Editoração musical: Edson Lopes. Tatuí: Conservatório Dramático e Musical “Dr. Carlos de Campos”, 1998. In: 
Syukhtun Editions. 1 partitura. Disponível em: <http://www.angelfire.com/sk/syukhtun/valsa.pdf $>$. Acesso em março de 2016. 